Renate Papke

\title{
Poems at the Edge of Differences
}

\author{
Mothering in \\ New English Poetry \\ by Women
}

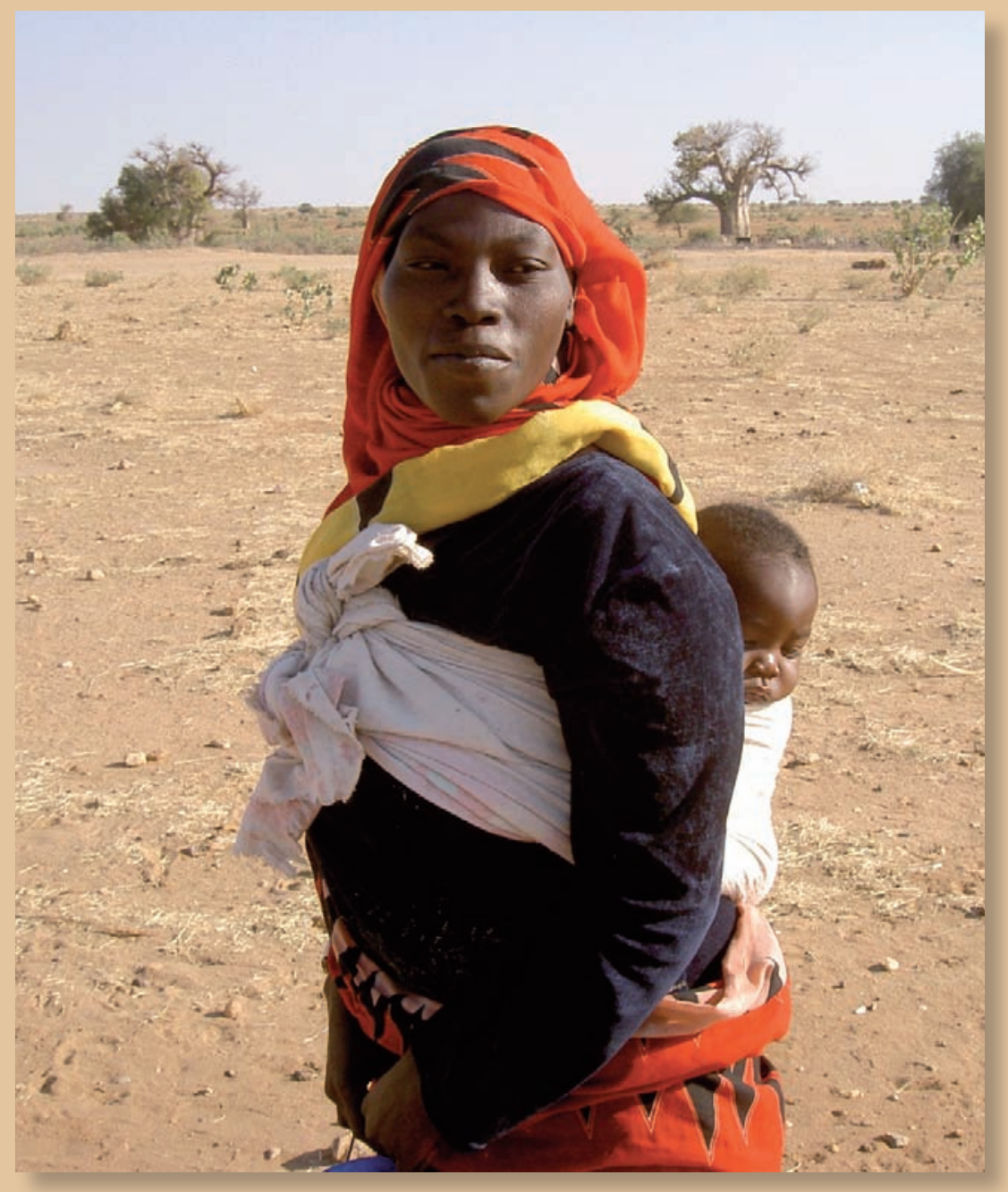

Universitätsverlag Göttingen 



\section{Renate Papke \\ Poems at the Edge of Differences}

This work is licensed under the Creative Commons License 2.0 "by-nd", allowing you to download, distribute and print the document in a few copies for private or educational use, given that the document stays unchanged and the creator is mentioned. You are not allowed to sell copies of the free version.

(c)

SORE RIGHIS RESERVED 
Erschienen im Universitätsverlag Göttingen 2008 
Renate Papke

Poems at the Edge of Differences:

Mothering in

New English Poetry

by Women

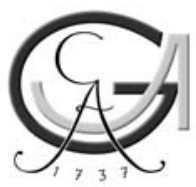

Universitätsverlag Göttingen 2008 


\section{Bibliographische Information der Deutschen Nationalbibliothek}

Die Deutsche Nationalbibliothek verzeichnet diese Publikation in der Deutschen Nationalbibliographie; detaillierte bibliographische Daten sind im Internet über $<$ http://dnb.ddb.de $>$ abrufbar.

\section{7 Göttinger Philosophische Dissertation}

1. Gutachterin: Prof. Dr. Brigitte Glaser, Universität Göttingen

2. Gutachter: Prof. Dr. Daniel Göske, Universität Kassel

3. Gutachterin: Prof. Dr. Regina Bendix, Universität Göttingen

Tag der mündlichen Prüfung: 28.02.2007

Address of the Author

renate.papke@t-online.de

This work is protected by German Intellectual Property Right Law.

It is also available as an Open Access version through the publisher's homepage and the Online Catalogue of the State and University Library of Goettingen

(http://www.sub.uni-goettingen.de). Users of the free online version are invited to read, download and distribute it. Users may also print a small number for educational or private use. However they may not sell copies of the online book.

Titelabbildung: Mother and Child in Darfur, Sudan 2004;

Samir Maleh, saudade@maleh.net

Abbildung S. 5: Girl in Bihar, India 2007; vivianisaac@cbnindia.org

Umschlaggestaltung: Margo Bargheer, Jutta Pabst

Satz und Layout: Monika Griebeler

(C) 2008 Universitätsverlag Göttingen

http:/ / univerlag.uni-goettingen.de

ISBN: 978-3-940344-42-7 


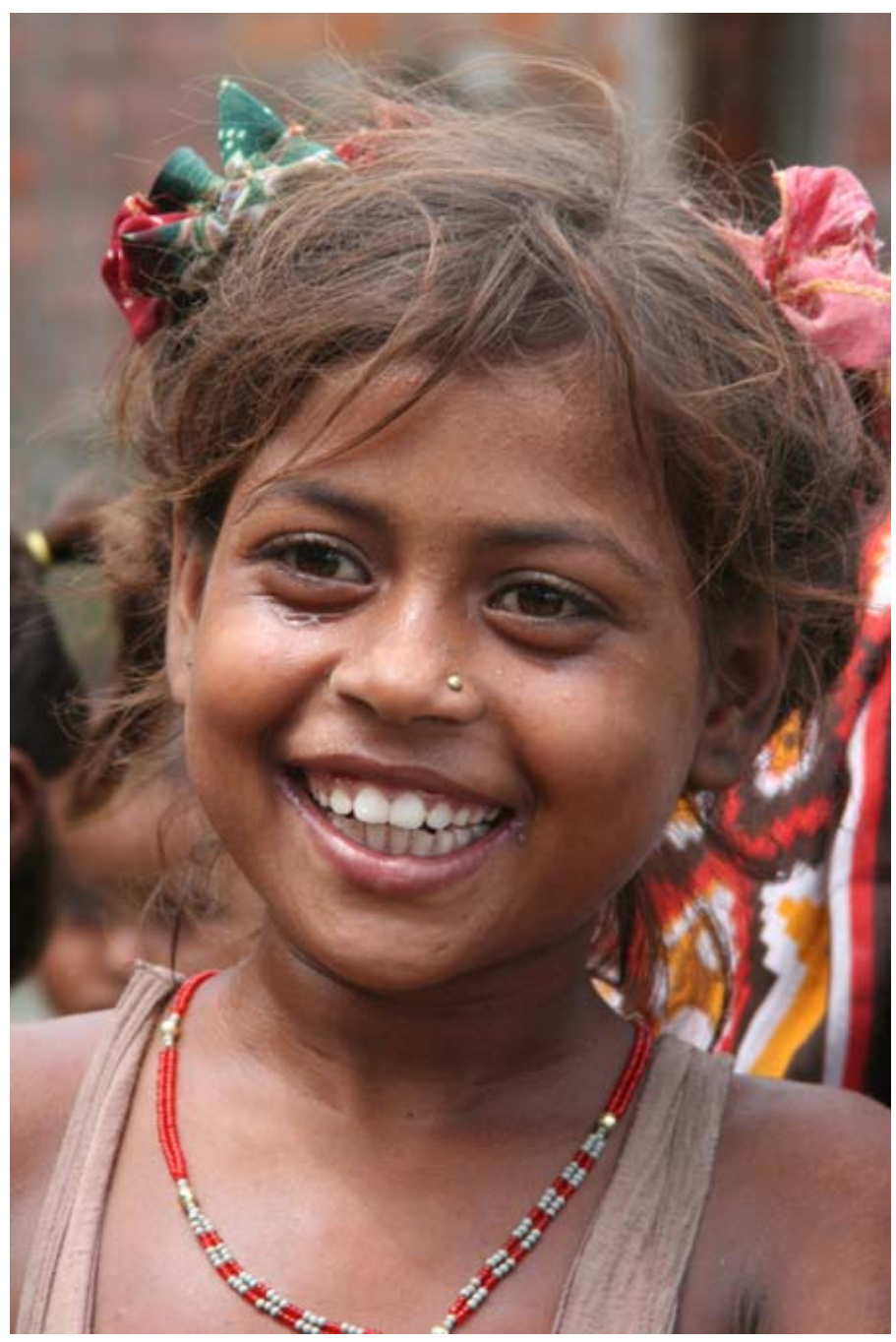


Fie, fie upon her!

There's language in her eye, her cheek, her lip, Nay, her foot speaks. Her wanton spirit looks out At every joint and motive of her body.

\author{
William Shakespeare, \\ Troilus and Cressida, Act IV, v, 55-58 \\ 1602
}

For women, then, poetry is not a luxury.

It is a vital necessity of our existence. It forms the quality of the light within which we predicate our hopes and dreams toward survival and change, first made into language, then into idea, then into more tangible action.

Poetry is the way we help give name to the nameless so it can be thought. The farthest horizons of our hopes and fears are cobbled by our poems, carved from the rock experiences of our daily lives... However, experience has taught us that action in the now is also necessary, always. Our children cannot dream unless they live, they cannot live unless they are nourished, and who else will feed them the real food without which their dreams will be no different from ours?

"If you want to change the world someday, we at least have to live long enough to grow up!" shouts the child.

- Audre Lorde -

Sister Outsider, 36-37

1984 


\section{Preface}

First scene: The labour-room of a hospital in northern Bihar/India in August 2007, a thirty-year-old woman has given birth to a healthy and beautiful daughter. Deeply disappointed, she turns away, when we show her the child: it is only a girl.

Second scene: I am on my way to the hospital. It is raining heavily. A family is walking in front of me. A childlike mother accompanies her three children to school. She and her fragile daughter are wet through. Both her sons, however, huddle together and protect themselves with the umbrella of the family.

In remembrance of these observations, I decided to return from my medical work to my dissertation and turn it into a book, whose commitment for women's selfesteem and self-confidence proves hopefully interesting for a large number of readers. Let us shout: "Women deserve umbrellas like men."

I wish to acknowledge my debt to Professor Dr. Brigitte Glaser and Professor Dr. Daniel Göske for examining my dissertation, for making many helpful comments and suggestions in their reports and in our lively and fair disputation, and for encouraging me on my way.

In preparing my text for publication, I followed the corrections and information given to me. Simultaneously, I wanted to preserve the spontaneity of my 
dissertation. I have therefore not attempted to transform the text by omitting questionable statements or by suppressing contradictions. I have appended, however, to particular chapters the questions and arguments of our disputation. In this way, my procedure reflects my concern to initiate dialogues and exchange between students, literary critics, theorists and activists of the women's movement in the Western and the "Third World". This concept also underlines the explorative and, by no means, concluding character of my work. 


\section{Table of Contents}

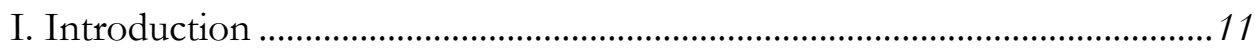

II. Concepts of Difference concerning Gender, Race and Ethnicity................................17

Difference concerning Gender .............................................................................. 17

Difference concerning Race ..................................................................................22

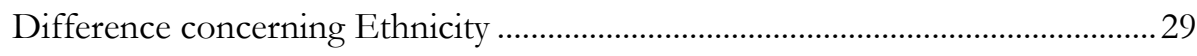

III. Mothering - a Human Experience in Practice and Theory ...................................37

IV. Why a Study about Poetry - not the Novel or Drama - on Mothering? ................41

V. Framework for a Pioneering Project ..................................................................43

VI. English Poetry by Women from India and the Diaspora ....................................52

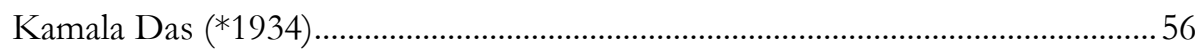

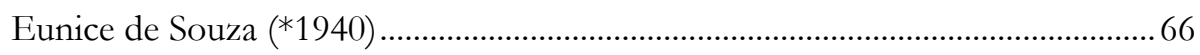

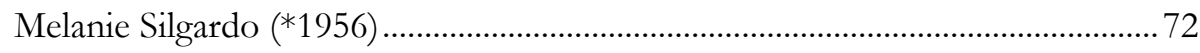

Sujata Bhatt $(* 1956)$........................................................................................... 76

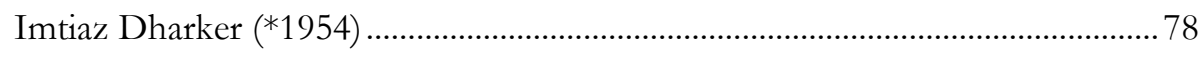

VII. English Poetry by Women from the Caribbean and the Diaspora .......................97

Una Marson (1905-1965) ........................................................................................ 99

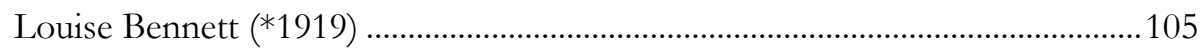

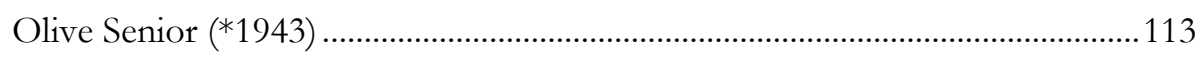

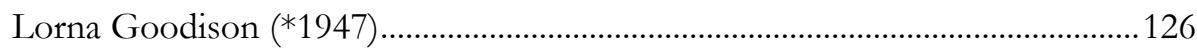

Jean 'Binta' Breeze $(* 1956)$..............................................................................136 
VIII. English Poetry by Women from Africa and the Diaspora ............................... 157

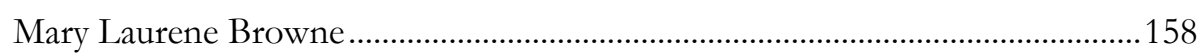

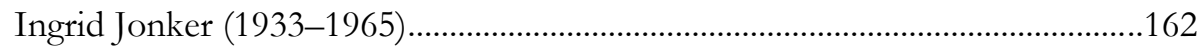

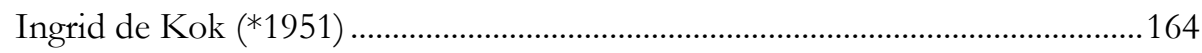

Mwana Kupona binti Msham (c.1810-c.1860) ....................................................168

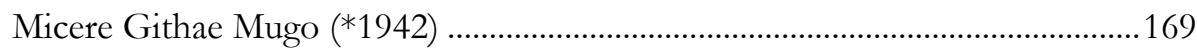

Ama Ata Aidoo $(* 1942)$.................................................................................. 172

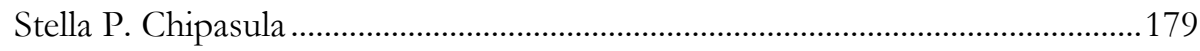

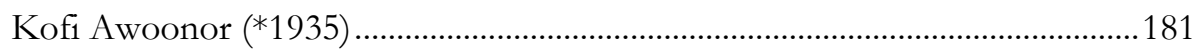

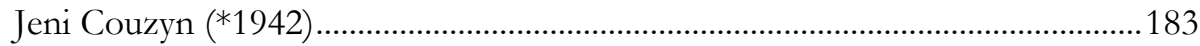

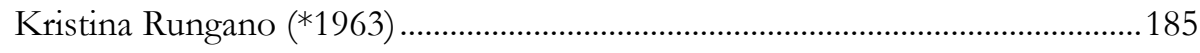

Lenrie Peters $(* 1932)$..................................................................................... 187

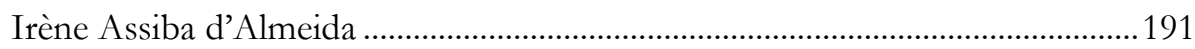

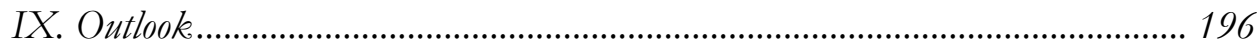

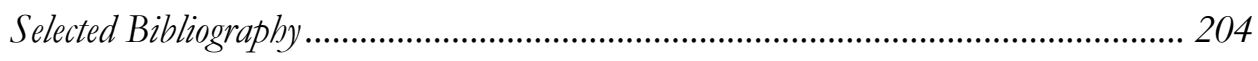




\section{Introduction}

A colon introduces a proposition, a summary, or a conclusion. The phrase Poems at the Edge evokes borders, divisions, exclusions. It refers to poetry about conflict and danger: a person clinging to the edge of a cliff is threatened to be blown into the sea and drowned. But the edge defines also a vantage point and a position for a keen and sharp view. "Mothering" is a particularly feminist issue and part of feminism's concern with difference. "Difference" or even "differences" are key terms in contemporary feminism, literal and material, in theory and politics.

Since the late 1970s, the acknowledgement of and the commitment to difference - of class, race, ethnicity, sexual orientation and age - has been foundational for feminist theory and activism. One reason can be found in the changing composition of societies, the development of new social movements and the globalization of the market place since the Second World War. Another reason is the impact of postmodernist, post-structuralist and post-colonialist theories with their scepticism towards universalist claims and their emphasis on fragmentation. Additionally, the intersection of feminism with cultural theory plays an important role. Stressing difference in feminist theories, agendas and political practices, feminism changed to feminisms in the late 1970s. These feminisms emerged out of deep divisions among national and international forms of feminism fighting against the tendency of some, especially white, heterosexual, western feminists to speak for all. 
During the last two decades, feminism has been impelled by relations of power which resulted in endless debates about oppressors and oppressed, white women and women of colour, First World/Third World, colonisers and colonised and, we and them. In some instances, these confrontations threatened or paralysed feminism's commitment to concrete social change and intensified the fear of the dissolution of feminism itself. Forced to redefine their concepts, feminist theorists and practitioners more and more respond to ethical and political challenges. The answers can be found in several publications of recent years, for example: Ann Brooks' Postfeminisms - cultural theory and cultural forms (1997), Chris Weedon's feminism, theory and the politics of difference (1999), and Susan Stanford Friedman's Mappings, Feminism and the Cultural Geographies of Encounter (1998).

Friedman's book has been highly influential for my work. The author judges difference, diversity and borders as positive phenomena provided that the debate is guided by tolerance and not by relations of power:
Borders have a way of insisting on separation at the same time as they acknowledge connection. Like bridges. Bridges signify the possibility of passing over. They also mark the fact of separation and the distance that has to be crossed. [...] But borders also specify the liminal space in between, the interstitial site of interaction, inter- connection, and exchange. Borders enforce silence, miscommunication, misrecog- nition. They also invite transgression, dissolution, reconciliation, mixing. $(1998,3)$

Friedmann refers to the notion of "borderland" coined by the Chicana poet Gloria Anzaldúa in Borderlands / La Frontera: The New Mestiza (1987): "A border is a dividing line, a narrow strip along a deep edge. The borderlands are a vague and undetermined place created by the emotional residue of an unnatural boundary. It is a constant place of transition" (3). Friedman promotes a "locational feminism" which is situated in those places where differences are negotiated and transformed:

A locational approach to feminism incorporates diverse formations because its positional analysis requires a kind of geopolitical literacy built out of a recognition of how different times and places produce different and changing gender systems as these intersect with other different and changing societal stratifications and movements for social justice. $(1998,5)$

Her study deals with stories and cultural narratives which demonstrate where and how feminism meets multiculturalism, globalism, poststructuralism. At the same time, the author builds a theoretical framework: narrative poetics instructs us how to analyse form and function of narratives in different cultures. In part I, for example, the author enlarges upon the encounter of feminism and multiculturalism and offers an analysis of Anzaldúa's Borderlands / La Frontera as a mythopoetic quest narrative that thematises and plays with the full spectrum of diverse views. Another example of locational feminism deals with "geopolitical literacy". The author juxtaposes Virginia Woolf's essay A Room of One's Own (1928) and Zora 
Neale Hurston's novel Their Eyes Were Watching God (1937). Through this comparison, she reveals the different conditions of racial and gender politics. Woolf demands a private room of their own for women, where they can realise their creativity free from everyday obligations. Hurston's protagonist Janie, however, longs to occupy a space on a communal porch - the masculine public space. In this way, Friedman requires the consideration of geography to complement historical analysis. Her aim is to negotiate between action and reflection, between theory and activism: "The stories they tell matter". "So do the stories we tell about them" (13). Whatever we do affects what we can know, and what we know shapes what we do.

My study arose from a personal concern and a personal preference. For the last five years, I have been working as a physician in slum areas in so-called "developing countries" (the Philippines, India, Bangladesh, Venezuela) and in countries devastated by war (Iraq, Liberia, Sudan). Almost all my patients have been mothers and children, because they are always the first victims of poverty and war. From these encounters, I began to recognise different forms of mothering, and I was introduced to different forms of social movements and advocacy groups. On the other hand, I have always liked, I love, poetry because it invites and forces me to a total response, emotionally and intellectually. No other literary genre makes me aware of the power of language as poetry does.

In my M.A.-thesis, Mothers and Poets: Mothering and Children in Modern American Women's Poetry (2004), I analysed the representation of mother-child-relations in contemporary American poetry by women, a topic which has been neglected so far in feminist and literary research. My M.A.-thesis aimed at challenging the assumption that women's writing is usually concerned with women's subordinate and problematic position in society. This point of view is, for example, expressed in the following passage of Rita Felski's Beyond Feminist Aesthetics - Feminist Literature and Social Change (1989):

The emergence of second wave feminism in the late 1960s justifies the analysis of women's literature as a separate category, not because of automatic and unambiguous differences between the writings of women and men, but because of the recent cultural phenomenon of women's explicit self-identification as an oppressed group which is in turn articulated in literary texts in the exploration of gender-specific concerns centered around problems of female identity. $(1989,1)$

The results of my M.A.-thesis contradicted this generalising evaluation of women's writing and corroborated Audre Lorde's metaphorical praise of women's power which is based on mothering:

Mothering. Claiming some power over who we choose to be, and knowing that such power is relative within the realities of our lives. Yet knowing that only through the use of that power can we effectively change those realities. Mothering means the laying to rest of what is weak, timid, and damaged - without despisal the protection and support of what is useful for survival and change, and our joint 
exploration of the difference. [...] I recall a beautiful and inticate sculpture from the court of the Queen Mother of Benin, entitled 'The Power Of The Hand'. It depicts the Queen Mother, her court women, and her warriors in a circular celebration of the human power to achieve success in practical and material ventures, the ability to make something out of anything. In Dahomey, that power is female. $(1984,173-174)$

In this study, I want to focus on the representation of mother-child-relations in contemporary poetry in English by women from India, the Caribbean, Africa and the corresponding diaspora in Great Britain. Doing research for my project, I encountered only three pre-cursors that deal with prose texts. In Whispers from a Continent: The Literature of Contemporary Black. Africa (1971), Wilfred Cartey used the motif of mother and child in order to identify a female presence in African literature. He is, however, not concerned with writing by women. In Mothering across Cultures - Postcolonial Representations (2002), Angelita Reyes analysed and contextualised with historical material the representation of mothering in novels by African, African-American and Afro-Caribbean women writers. She used her own experience and the tradition of her black family as well. As a woman of colour, her position regarding the texts is different from mine. My experience as a white European woman imposes limitations that must always be kept in mind when I am writing about texts by black women. But my personal experience has helped me to overcome at least some of my doubts and apprehensions. Working as a physician, I have usually been able to build up a confidential relationship with my patients, through compassion, respect and professional skill. The mother and the doctor, both, are concerned with the needs and the well-being of the child. But even in this intimate situation, I must also, always, be aware of our differences before I dare to speak about my impressions and observations, because I can only enter a foreign society as a visitor. The reference to my work as a physician is, by no means, meant as a gesture of self-authorisation. The same observation applies to my situation as a reader: I always bring my own expectations and literary experience to bear upon the text. On the one hand, there is always the risk of a "eurocentric" perspective. On the other hand, however, there is the advantage of juxtaposition that guides me to abandon the privilege of the West as the basis comparison and to stress the importance of exchange. Finally, in Motherland - Black Women's Writing from Africa, the Caribbean and South Asia (1991), I found in Susheila Nasta the third pre-cursor. The author explored the subject of motherhood in women's writing in the context of postcolonial literature and opened a debate across cultures. She also focused on fiction and already pointed at the need for books dealing with poetry or drama. In her essay "Beyond the Millennium: Black Women's Writing” (2000), she states, however, that black women's writing still does not attract critical attention. These publications and commentaries underline the timeliness of my project. In my study, I will take up this task. 
My study consists of two parts. The first part will offer an overview of feminism's theory of difference and of its encounters with the theories of postmodernism and post-colonialism. It will look at feminism's different concepts of "mothering" and provide considerations on poetry and poetics. In the second part, I will deal with the textual analysis of poems about "mothering". This is a text-centred approach which concentrates on the representation of mothering in particular poems. It offers a close reading of the poems on the aesthetic level and takes into account detailed contextualisation: short biographies of the artists will show the circumstances and motives of their writing and, more important still, focus the attention on the political realities and everyday experience on which their poetry is based. In this way, the poems are located within the respective society, history and culture. It is not my intention to seek recourse to "mothering" in order to specify a universal and unique feminine characteristic. My aim is, first, to find out how these poems represent the complexity of motherhood and maternal activities as a sexual, biological, psychological, emotional, cultural and political experience. Second, I ask whether the representation of mothering could lead to a communication between women that could be used as a bridge for overcoming the differences between race and ethnicity. Sometimes these poems tell about conflicts and sometimes about cohesion, but always about a main concern of women which could link knowledge and emotion, social responsibility and collective struggle to initiate a politics of women's - but not only of women's - solidarity.

Yet, it is by no means my intention to read the selected poems "didactically". My reading of poetry is shaped by Jacques Derrida's short essay "Che cos' è la poesia?" ("What is poetry?" or more literally, "What thing is poetry?") (Kamuf 1991, 223). Derrida compares a poem to a hedgehog and the critical writing on poetry to the hedgehog's crossing of a road, where it is in danger of getting lost or being run over. Bristling with difficulties, it protects itself and asks for protection on its movement or rather transport from poetic language to critical commentary. That is why the poem appeals to the heart and the mind. My study aims at getting the hedgehog safely across the road.

Since I have introduced two translated poems into my work, I will shortly deal with the question whether and how poetry is translatable. The literary critic depends on the work of the translator, who is responsible for the precise content and the true aesthetic effect. The reception of the text is the first easier step, the production of the translation the second and most difficult. Poetry deals with feelings and emotions. The poet feels and expresses his feelings in her/his language. The translator can hardly ever feel in the foreign language; he can only translate and express feelings. Since language and culture are interdependent, the translator should be familiar with the source culture and the target culture. Both, reception and production, should respect all elements that create a poem: statement, meaning of the words, emotional and spiritual atmosphere, metre, rhythm, sound. A sensitive translation should preserve the unity of all these elements. But 
even when it reaches this goal, there will be a gap between original and translation. This concise overview hints at the great expectations towards and the shortcomings of a translated poem.

My introduction explained the relationship between both propositions of the title: the first part addresses the edge as a metaphor of difference and border; the second part evokes with the concept of "mothering" a borderland, a zone of contact and transition. It leads from the discourse on difference to the possibility of a communicative bond between women as the basis for politics. The part of the title after the colon challenges what comes before it.

Appendix: The term "mothering" is problematic because it seems to imply a sexspecific essentialism. But the ambivalence of a term does not justify its abolition. I deliberately maintain its use as a metaphorical comprehension and subscribe to Audre Lorde's figurative, however vague, description for my work on poetry. In a particular chapter on mothering, I enlarge upon the more precise and not sexspecific concepts of care-taking, nurturing and social parenthood which include men into the care-taking community. I will not do away with the problems of women's identity and women's oppression by foregrounding the social aspect of the mother-child-relation as women's main responsibility. But I want to go beyond identity politics that circle around women's victimisation. If feminism is based on two shared principles: first, the oppression of women and, second, the commitment to social change, then it is time to concentrate on the second. I cannot see a "back-lash"-position for feminism in this argumentation.

I also cling to Derrida's nicely put, however not precise, picture of how to read and to treat a poem. It supports my rejection of a narrow, normative and educative reading of poetry that the slightly provocative title of my work could suggest. 


\section{Concepts of Difference concerning Gender, Race and Ethnicity}

"A passion for difference" (Henrietta Moore 1994), "the difference impasse" (Mary Louise Fellows and Sherene Razack 1994) and "strategic essentialism" (Gayatri Chakravorty Spivak 1984) seem to characterise and to dominate contemporary women's movements as well as present theory and politics of feminism. On the one hand, difference is celebrated because it transforms and enlarges knowledge and is regarded as a source of creative empowerment for feminism. On the other hand, endless discussions make it difficult or even impossible to find a common ground from which to organise social change. Critics of the celebration of difference draw attention to the inherent dangers that ignore the hierarchical relations of power involved. Can we regard "strategic essentialism" as an answer to the dilemma? "The term carries the belief that the use of essentialist categories may be strategically necessary in the fighting of certain battles" (Hawthorn 2000, 109). Some critics of this term object to the militant language, while others find themselves excluded by the sophisticated postmodernist discourse. This chapter tries to integrate theory and politics of feminism. It approaches difference concerning the categories of gender, race and ethnicity historically, culturally, socially and politically.

\section{Difference concerning Gender}

The assumption that women and men are intrinsically different governs the history of Western civilisation. Biological theories of difference focus on women's and men's different reproductive roles and comprise physical, emotional and intellectual features. Since the early 1970s, feminists have adopted the term 'gender' from psychology in order to distinguish between the social and cultural representation of women and men and the biologically determined sex. Gender studies are 
concerned with the hierarchy and the struggle for power in the relation between women and men. They simultaneously regard the influence of class, race, ethnicity and sexual orientation. Current studies question, however, the sex/gender model and the mainly biological explanation of "sex", which they declare as historical and cultural construct as well:

The term 'gender' was adopted by feminists to emphasise the social shaping of feminity and masculinity, to challenge the idea that relations between women and men are ordained by nature. Sometimes a distinction is made between 'sex' as the biological difference between male and female and 'gender' as the cultural distinction between femininity and masculinity along with the social division between women and men. Not all feminists accept this distinction. Some think that it denies the importance of the physical body, while others argue that our understanding of the anatomically sexed body is itself socially constructed. (Jackson/Scott 1996, 2)

This concise text puts emphasis on three aspects of the sex/gender distinction and reflects the theoretical background of feminism as a social-political movement. The following overview develops these three steps taking into consideration postmodernist and poststructuralist theories of difference which have influenced feminism since the 1970s.

From the beginnings of liberalism in Europe and America, initiated by the American Declaration of Independence in 1776 and the French Revolution in 1789 , liberal feminists insisted on women's equality with men and fought for equal civil rights for women concerning suffrage, education, access to professions and property rights. Equality was regarded in terms of rationality, and in terms of Christian - namely protestant - thought. This first-wave feminism neglected emotions and the social significance of the body and confined interpersonal relations to the private sphere of the nuclear family. It minimised differences between women and men and was answered and followed by a move to celebrating a woman-centred perspective.

Second-wave feminism, also called revolutionary or radical feminism, developed in the 1960s and changed the political climate with its revolutionary principle that "the personal is political". The "sexual liberation" and improved methods of contraception and birth control created the condition for politics that emphasised body, sexuality and procreation. Gender came to be defined within patriarchy, the system of male oppression:

Patriarchy is the power of the fathers: a familial-social, ideological, political system in which men - by force, direct pressure, or through ritual, tradition, law, and language, customs, etiquette, education, and the division of labor - determine what part women shall or shall not play, and in which the female is everywhere subsumed under the male. It does not necessarily imply that no woman has power, or that all women in a given culture may not have certain powers. (Rich 1977, 57)

Second-wave feminism added a new dimension to women's emancipation: the idea of a woman's right to enjoy and to control her own body. This feminism 
opposed psychoanalysis which traditionally characterised women in terms of deficiencies. Women's bodies are now regarded as the focus of their oppression, but also as the basis of women's power, of their positive difference from men:

Patriarchal thought has limited female biology to its own narrow specifications. The feminist vision has recoiled from female biology for these reasons; it will, I believe, come to view our physicality as a resource, rather than a destiny. In order to live a fully human life we require not only control of our bodies (though control is a prerequisite); we must touch the unity and resonance of our physicality, our bond with the natural order, the corporeal ground of our intelligence. (Rich 1977, 39)

Since the 1960s, the emphasis on women's body and biology has shaped contemporary feminist theory and politics. Since that time, feminism has become more and more an international movement which has established social changes in developed and developing countries. Yet, the nature of patriarchy became the issue. Early radical feminism insisted on the universal nature of patriarchy regarding it as the fundamental form of oppression for all women and developed the concept of a global sisterhood. In the late 1970s, however, the concept of a universal authority of female experience of oppression came to be criticised mainly by women of colour, who protested against a white, middle-class feminism with its preoccupation with the self. Feminists of colour, working-class women and feminists from the Third World opposed the pretence to the homogeneity of female experience of oppression.

"Woman-centred research" emerged in literature departments of the western academic world. From the beginning, literature played an important role. Feminist literary critics maintained that patriarchal meanings and values pervaded all aspects of culture from science to literature and worked on woman-centred approaches to different domains: history, literature, social sciences, philosophy and psychology. On the one hand, their woman-centred research aimed to recover a lost female history, to document gender-specific female experience, to analyse the role of the female reader and writer. It was mainly preoccupied with social and cultural change and differences in women's and men's language were regarded as historically produced. On the other hand, woman-centred writing explored the question of a specifically female aesthetic. Influenced by psychoanalysis, French feminists Luce Irigaray and Hélène Cixous argued that women naturally have concepts that are different from men, and that there exist female imagery, myths and writing which are rooted in women's body and biology and challenge the patriarchal symbolic order.

Her second concern was in writing that connected subject matter and language and offered alternative positive images of women. Women's bodies were no longer described as a focus of male control within the patriarchal system but as a site of power. Women's sexuality and capacity for self-determined forms of motherhood were celebrated. Previously disregarded experiences of women's lives such as childbirth and mothering became the subject of art and of politics and activism 
in environmental, anti-nuclear, peace and health movements. In spite of several controversial issues, these movements offered a common ground for women who do not, or only partly, identify with radical feminism's interpretation of gender difference and its claim of a near-universal patriarchal system.

The third and most modern development in sex/gender difference refers to non-universalist and historically specific theories of the body. Since the 1970s, feminist theory has been influenced by postmodernist and poststructuralist theories which radically changed approaches to gender difference. These theories reinforced critiques that had already been directed by women of colour and other minority groups against the universalist claims of radical branches of feminism. Since both fields of theory have not only been fundamental for the question of gender, but also for the issues of race and ethnicity and the development of postcolonial theory, both will be discussed in more detail. Postmodernism, which draws on the works of the French philosophers Lyotard and Baudrillard, regards all historical knowledge of the world as narrative. Confronted with the memory of two World Wars, gas chambers, concentration camps, the Holocaust and the postcolonial predicament in the first half of the twentieth century, the postmodern condition is characterised by a loss of faith in many Enlightenment theories of liberation, education and progress. Postmodern social theory argues that the 'grand narratives' of emancipation in Western history, like liberal humanism, have broken down. Liberal humanism is regarded and dismissed as a meta-narrative that assumes to define what is universally good and true. Global and transhistorical accounts of patriarchy are rejected as meta-narratives that draw on and universalise Western standards and experience.

Based on the work of Derrida and Foucault, poststructuralist theories of language, meaning, subjectivity and power have challenged theories of sexual and gender difference that assume a fixed meaning of bodies. Poststructuralism maintains that there is no natural or given truth or meaning in the world. Meaning is created by language. Derrida argued that meaning of difference is produced through hierarchical binary oppositions such as male/female, white/black. Yet, since language is plural and always historically and culturally specific, it will result in various definitions of difference. Foucault enlarged this linguistic concept with his theory of discourse and representation. As a linguistic concept discourse means passages of connected speech or writing beyond the limits of the sentence. For Foucault, however, it is not a purely linguistic concept, but it is about language and practice. Foucault describes his position in his book The Archaeology of Meaning:

The longer I continue, the more it seems to me that the formation of discourses and the genealogy of knowledge need to be analysed, not only in terms of types of consciousness, modes of perception and forms of ideology, but in terms of tactics and strategies of power. $(1977,162)$ 
Discourse in this context is a collection of statements on a common object of analysis. This group of texts represents the knowledge about a special topic at a particular historical moment. This knowledge is put to work through discursive practices in order to regulate the conduct of others. In this approach, knowledge is always linked to power and has the power to make its concepts seem true. All knowledge has real effects and in this sense exerts power.

The second concept in Foucault's theory is "representation". From the linguistic perspective, „representation” includes links between three different levels: the real world (things, people, events), the conceptual world (mental concepts) and the signs arranged into language which communicate these concepts. There is a process of substitution at work: to represent something is to call it to mind by description, portrayal and imagination. It also means to symbolise, to stand for. Representation is the process by which members of a culture use language to produce meaning. Representation and discourse, the production of meaning through language and image, are the key concepts for the interpretative work in the humanities. Representation additionally carries a second meaning: the political. Politicians represent or stand for the population at large. Feminists have taken up these linguistic approaches as a more productive way of analysing the sex/gender difference. In bringing postmodern and poststructuralist theories to bear on feminist theory, especially the lesbian and queer branch, Judith Butler questions the biological basis of the sex/gender difference. In Gender Trouble (1990), the author maintains that sex cannot be regarded as a biological or natural basis on which gender is imposed:

It would make no sense, then, to define gender as the cultural interpretation of sex, if sex itself is a gendered category. Gender ought not to be conceived merely as the cultural inscription of meaning on a pre-given sex (a juridical conception); gender must also designate the very apparatus of production whereby the sexes themselves are established. As a result, gender is not to culture as sex is to nature; gender is also the discursive/cultural means by which 'sexed nature' or 'a natural sex' is produced and established as 'pre-discursive,' prior to culture, a politically neutral surface on which culture acts. (Butler 1990, 7)

In privileging language and following the „linguistic turn” of post-structuralism, Butler contests the binary concept of male/female subjectivity and regards gender as a performance and citation. The title of her book suggests that she wants to „trouble" the category of gender through parody and play. On the one hand, the concept of a performative gender contains a liberating force for the individual. On the other hand, the idea of uncertainty and a ,political neutral surface” contains the danger of forgetting the ever existing relations of power.

Many feminists regard the relation between feminism, postmodernism and post-structuralism as highly problematic. Some radical feminists object to the reliance on male theorists. For others, the denial of gender difference and women's specific experience endangers feminism as a movement for social 
II. Concepts

change. In her book Feminist Practice and Poststructuralist Theory (1987), Chris Weedon contradicts these apprehensions. She regards feminism and post-structuralism as conceptual and political allies, which overcome the separatism of second-wave feminism and lead to adequate politics in the current political context:

For a theoretical perspective to be politically useful to feminism, it should be able to recognize the importance of the subjective in constituting the meaning of women's lived reality. It should not deny subjective experience, since the ways in which people make sense of their lives is a necessary starting point for understanding how power relations structure society. Theory must be able to address women's experience by showing where it comes from and how it relates to material and social practices and the power relations which structure them. [...] In this process subjectivity becomes available, offering the individual both a perspective and a choice, and opening up the possibility of political change. (1987, 8-9)

She maintains that feminist post-structuralism offers "a contextualisation of experience and an analysis of its constitution and ideological power" $(1987,125)$. With her vocabulary and language, Weedon remains within the old rules of academic writing, while Butler develops her critique through a playful rhetoric. Her strategy also provokes new understanding of social categories and can by no means be charged with political irresponsibility.

In concluding this chapter on gender difference, I want to return to the metaphors of edge and borderland in my introduction. With poststructuralist theory, Derrida and Foucault overcame the edge of hierarchical mainly French binary opposition and evoked a borderland, a zone of contact and transition with the emphasis on plurality and the historical and cultural specificity of language and meaning. Hopefully, the idea of plurality in postmodernism will lead to more respect for difference - not only in relationships between women and men, but also between women and women and men and men. The problem of dealing with difference, not as a restrictive but as a liberating force, remains urgent for contemporary feminism theoretically and politically. The history of gender relations did not start with discursively produced differences: women experienced gender differences materially as social injustice, oppression and often as violence. This is still more evident for the experience of racial difference: the issue of the next chapter.

\section{Difference concerning Race}

The concept of race is based on the assumption of a hereditary relation between phenotype - skin-colour, hair texture, lip size and other physical traits - and intellectual and emotional qualities. Race in the past was regarded as a natural quality which conditioned anatomy, thought and feeling. Racism links these differences to notions of superiority and inferiority. Although there are some examples of racial difference and hierarchy in India and China before contact with the West, the 
pseudo-scientific concept of race and racism began in the eighteenth century with western enlightenment philosophy, liberal humanism, "theology" and the development of the natural sciences. By categorising the races in the Great Chain of Beings from pre-historical savagery to the present state of civilisation, Enlightenment thinkers put themselves on the top of the scale. Pseudo-scientific explanations derived from ethnography, phrenology, physiognomy, genetics and were almost always related to value judgements. Modern racial politics has been connected with J.A. de Gobineau's Essay on the Inequality of Human Races (1853), in which he distinguished three distinct human races: black, yellow and white. The author developed a global concept of race and racism based on the assumption that all civilisations were dependent on white Europeans. These arguments were used to justify the politics of imperialism and colonialism, slavery and segregation, concentration camps, gas chambers and the Holocaust.

Racist stereotypes and prejudices are still deep-rooted within the social structures of contemporary western societies. Especially black women had and still have to face the brutal consequences in every day life and engaged themselves in liberation movements early. Already in the nineteenth century, black women in America participated in both the struggle for racial equality and the Women's Rights Movement. Even before the 1950s and 1960s, black women were a part of the Civil Rights Movement and fought together with black men as well as with white women and men against racial discrimination and oppression. The activism sparked by the Civil Rights Movement revived the Women's Rights Movement, yet only few black women participated in this second wave of feminism. Black feminists like bell hooks, Audre Lorde, Alice Walker faced three main problems. First, they had to overcome black women's rejection of feminism. Second, they had to oppose the homogenising tendencies of white feminists. Third, they had to resist black women's exclusion from new feminist historical and cultural canons. The critical perspectives expanded by these African American feminists have been fundamental for the development of black female aesthetics. They have also been influential for writers in post-colonial societies and for the present relation between First World and Third World feminism. Since these studies address the main issues of my project, I will dwell on them in more detail.

Black women's rejection of feminism was partly a reaction to white women liberationists, partly a gesture of solidarity with black men. Many black women thus refused to acknowledge the problem of sexual oppression. In Sister / Outsider, the African American poet and socialist feminist Audre Lorde describes the situation:

For us, increasingly, violence weaves through the daily tissues of our living. [...] Because of the continuous battle against racial erasure that Black women and Black men share, some Black women still refuse that we are also oppressed as women, and that sexual hostility against Black women is practised not only by the white racist society, but implemented within our Black communities as well. Exacerbated by 
racism and the pressures of powerlessness, violence against Black women and children often becomes a standard within our communities, one by which manliness can be assured. (1984, 119-120)

Audre Lorde makes clear that the struggle to end racism and the struggle to end sexism cannot be separated.

This is also the concern of bell hooks' Ain't I a Woman (1981), which became a landmark in the history and the theory of black women and feminism. The title renders homage to the nineteenth century black feminist and abolitionist Sojourner Truth, and hooks begins with the impact of sexism on black women during slavery. She presents the stereotypical and devaluating images of black womanhood based on the myth that all black women are immoral and sexually loose, yet criticises the romanticising representation of the strong black woman as devoted to the task of mothering and able to cope with all forms of oppression. She plainly states the sexist attitudes that resulted in black patriarchy and still prevailed in the Civil Rights Movement and Black Panther Party during the 1960s. The author points out that already in the context of slave plantations white women had often been complicit in black women's exploitation. She rejects white feminists' assertion of common oppression as ignorance and their desire for sisterhood as a patronising and opportunistic attitude. Nevertheless, bell hooks is not pessimistic:

The sisterhood that is necessary for making the feminist revolution can be achieved only when all women disengage themselves from the hostility, jealousy, and competition with one another that has kept us vulnerable, weak, and unable to envision new realities. That sisterhood cannot be forged by mere saying of words. It is the outcome of continued growth and change. It is a goal to be reached, a process of becoming. The process begins with action, with the individual woman's refusal to accept any set of myths, stereotypes, and false assumptions that deny the shared commonness of her human experience; that deny her capacity to experience the Unity of all life; that deny her capacity to bridge gaps created by racism, sexism, or classism; that deny her ability to change. The process begins with the individual woman's acceptance that [...] we must consciously work to rid ourselves of the legacy of negative socialization. $(1981,157)$

In white women's responses to racism three main attitudes can be differentiated: the denial of racial difference or the reduction of racial difference to an individual prejudice; a sense of guilt which is often paralysing, the transformation of racism into a black problem and the rejection of any responsibility for it. The question of white women's privilege and complicity in black women's exploitation remains central in discussions between First World and Third World feminism, and white women are still being asked to recognise racism and to analyse both its individual and institutional dimensions. In Ain't I a Woman, bell hooks documented the history of racism and sexism afflicted on black women, in Sister / Outsider, Audre Lorde opened another chapter of black women's history. 
At the centre of African American feminism is the belief that for black feminist criticism aesthetics and politics are inseparable. The analysis of patriarchy became a point of opposition to the homogenising tendencies of white feminists and the exclusion of women of colour from new feminist history and aesthetics. In her discussion of Mary Daly's Gyn / Ecology (1979), Audre Lorde agreed with Daly's cross-cultural depiction of women's oppression throughout the ages, but she contradicted universal structures of patriarchy and criticised the denial of important aspects of other women's culture and their resistance to patriarchy. In Gyn / Ecology, Daly maintained that with the establishment of Christianity as the dominant religion in the West, the status of women in society, religion, myth and language changed dramatically. Instead of the pre-Christian goddesses who symbolise fertility, sexuality and power, Christianity worships a male God and the image of a virgin mother. Daly included examples of white European women's power, but restricted examples from Africa to female victimisation. In a public letter to Daly, Audre Lorde argued:

The oppression of women knows no ethnic nor racial boundaries, true, but that does not mean that it is identical within those differences. Nor do the reservoirs of our ancient power know these boundaries. To deal with one without alluding to the other is to distort our commonality as well as our difference. $(1984,70)$

Audre Lorde's passionate argument was a milestone. On the one hand, she anticipated present discussions between First World and Third World feminists and went beyond their present social situation. On the other hand, she connected black women's difference to their roots in a distinctive Afrocentric women's culture and history. The influence of transplanted and partially transformed West African cultural forms - cosmology, myths, modes of representation and expression - has since become a crucial issue of black female aesthetics and identity politics. Influenced by the broader Afrocentric movement, some African American critics even assume a given African cosmology and the notion of an authentic black identity. Yet, these essentialist tendencies came to be criticised, particularly by postmodern black feminism to which I will return later.

Besides Audre Lorde, bell hooks and Alice Walker have taken a womancentred approach. In her essay collection In Search of Our Mothers' Gardens: Womanist Prose (1983), Alice Walker deals with all concerns of black feminist criticism. She challenges the literary canon and directs our attention to other forms of black women's culture and language. Alluding to her novel The Color Purple Walker defines "womanist" in contrast to "feminist": "Womanist is to feminist as purple is to lavender" (1983: xii). The author struggles against the invisibility of black women's creativity and artistic achievements in new feminist historical and cultural canons. Alice Walker also rediscovered the work of Zora Neale Hurston, the most prolific black American woman writer between 1920 and 1950. An anthropologist, folklorist and creative artist, Hurston celebrated the rich cultural heritage of black people and the beauty of black expression. In her most successful novel Their Eyes 
were watching God (1937), the female protagonist gains access to the porch, the public space of men, and narrates her search for identity in the vernacular. Hurston explored early feminist concerns and has become the admired and loved foremother of a generation of black women writers. In her moving essays, Alice Walker reveals how the restrictions of slavery and racism stifled the creativity and spirituality of black women. Walker traces the suppressed creativity of black women to non-verbal art forms: gardening, quilting, cooking and sewing. She reveals black women's relationship with oral tradition, folk memories and the magic realm, their use of herbal medicine, their intimate knowledge of pregnancy and motherhood and their co-operation with each other in special forms of women's bonding. The author draws our attention to the representation of female experience, to the modes of expression, to images and metaphors. Alice Walker's research has been more descriptive and practical than theoretical and asks for additional work on Black feminist aesthetic.

In her essay "Toward a Black Feminist Criticism" (1977), Barbara Smith, one of the first black feminist theorists, develops a black feminist aesthetics based on the specific political, social and economic experience of black women and on the assumption of a specifically black female language. She aims at recovering the writings of black women for critical examination. She also develops reading strategies which are attentive to the intersections of gender, race and class in the texts. Critics like Deborah E. McDowell have expanded these considerations. In her essay "New Directions for Black Feminist Criticism" (1980), the author maintains the necessity of contextual approaches to black women's literature. She asks for a textual analysis and a theoretical framework. But at the same time, critical voices could be heard against an increasing tendency to privilege Western theory on texts of black authors. Similar to Alice Walker, Barbara Christian brings black theory back to its experiential and communicative roots. In her article "The Race for Theory" (1987), she describes the following process:

People of color have always theorized - but in forms quite different from the Western form of abstract logic. And I am inclined to say that our theorizing (and I intentionally use the verb than the noun) is often in narrative forms, in the stories we create, in riddles and proverbs, in the play with language, since dynamic rather than fixed ideas seem more our liking. [...] My folk, in other word, have always been a race for theory - though more in the form of the hieroglyph, a written figure which is both sensual and abstract, both beautiful and communicative. Among the folk who speak in muted tones are people of color, feminists, radical critics, creative writers, who have struggled for much longer than a decade to make their voices, their various voices, heard, and for whom literature is not an occasion for discourse among critics but it is necessary nourishment for their people. $(1987,51-$ 63)

Barbara Christian expands her critique in her ironic and impressive article "The Highs and the Lows of Black Feminist Criticism" (1990). Referring to Alice 
Walker's distinction between black women's "high" and "low" art, Christian develops the following overview:

In the high world: Discourse, theory, the canon, the body, the boys (preferably Lacan, Derrida, and Foucault) before the girls, linguistics, the authority of the critic, the exclusion of creative writings.

In the middle world: Reading the texts, sometimes of creative writers; negotiating between advancement and appreciation; tropes, research, discourse; now I understand my mother; narrative strategies. What does it mean? the race for theory.

In the low world: Stories, poems, plays. The language of the folk. Many bodies the feeling as one with June, Alice, Toni. $(1990,55)$

In Christian's writing, we encounter the playful way in which postmodernism and postcolonialism deal with theoretical discourse. In a more analytic way, Deborah E. McDowell, develops a critical standpoint against the present practice of institutionalised theory in her essay, "Recycling - race, gender, and the practice of theory" (1992). Highly attentive to the influence of power, the author interrogates the relations between race, gender and theory by confronting black feminist criticism and post-structuralism. She differentiates these power relations according to Audre Lorde:

Racism, the belief in the inherent superiority of one race over all others and thereby the right to dominance. Sexism, the belief in the superiority of one sex over the other and thereby the right to dominance. Ageism. Heterosexism. Elitism. Classism. (Lorde 1984, 115)

McDowell isolates the specific points of interest in both black feminist and poststructuralist criticism revealing correspondences concerning the authority of experience, the practice of interpretation, the importance of the author and the text. Although both approaches analyse the relations between the margins and the centre, she argues that black women's criticism is still disregarded by academic institutions and has been excluded from the category of theory. The Western academy propagates the continued denial of black women's intellectual achievements. The question arises whether this attitude can be regarded as a blatant example of the theory/practice dichotomy. Poststructuralist theory preaches diversity, yet does not accept it in practice. McDowell's argumentation seems to be an answer to bell hook's essay "Postmodern Blackness" (1991). On the one hand, this black intellectual of the first generation criticises the exclusionary tendencies of postmodern theories. On the other hand, she acknowledges its potentially liberating power:

Postmodern discourses are often exclusionary even as they call attention to, appropriate even, the experience of 'difference' and 'Otherness' to provide oppositional political meaning, legitimacy, and immediacy when they are accused of lacking relevance. $(1991,23)$ 
Employing a critique of essentialism allows African-Americans to acknowledge the way in which class mobility has altered collective black experience so that racism does not have the same impact on our lives. Such a critique allows us to affirm multiple black identities, varied black experience. It also challenges colonial imperialist paradigms of black identity which represent blackness one-dimensionally in ways that reinforce and sustain white supremacy. This discourse created the idea of the 'primitive' and promoted the notion of an 'authentic' experience, seeing as 'natural' those expressions of black life which conform to a pre-existing pattern or stereotype. Abandoning essentialist notions would be a serious challenge to racism. $(1991,28)$

I return again to the metaphors of edge and borderland. Concerning racial difference, the poststructuralist critique of essentialism offers a "site" - a broader description and definition of black experience and black identity - and allows us to imagine multiple identities. Yet, the reality of most black women's lives contradicts the notion of choice. They remain subject to discrimination and exclusion. Their identities remain fixed by sexual and racial stigmata. Poststructuralist theory suggests new forms of identity that are open for change and important for imagining a different future. Poststructuralist approaches to political practice have to take into consideration the material reality of social oppression and exploitation. Shared social commitment rather than shared identity is necessary to overcome the border between theory and practice.

African American studies as well as postcolonial studies aim at defining and destabilising racial hierarchies. New sociological and literary approaches, for example, Gina Wisker's Post-Colonial and African American Women's Writing - A Critical Introduction (2000), bring together overlapping and contrasting areas of African American and postcolonial women's writing. African American feminism has been fundamental for the development of a black female aesthetics as well as a black female consciousness and opened the discussion with postcolonial feminism about the intersection of race, ethnicity and gender politics. Both, the African American and the postcolonial feminist critic question their location within the western academy. Postcolonial feminist critics like Gayatri Chakravorty Spivak and Chandra Talpade Mohanty, who are totally or partly embedded in the western academy, discuss their position as First World scholars and Third World feminists in their works. These perspectives from "other worlds", to quote Spivak, will be the topic of the next chapter concerning ethnicity. Does feminism need a "strategic essentialism" to beat the western institutions - predominantly represented by white male scholars - at their own game or must and can it develop other concepts? My work tries to answer this question. 


\section{Difference concerning Ethnicity}

After the fascist abuse of the term "race", the term "ethnicity" is often used as a replacement, but it is not to be confounded with it. Ethnicity is a question of history, language, culture and place. It has to do with difference and sameness, with identity and belonging. Ethnocentrism links ethnicity to value judgements. It puts one's own culture at the centre, devalues and stereotypes other cultures. To speak another language, to belong to another culture are not the same as to belong to another race. Yet, women in minority groups living in predominantly white societies often experience racist prejudices. They fight for the recognition of their ethnic particularity and regard themselves as women of colour. In a global frame, this term includes all women who are not defined as white, especially Indian, Asian, Caribbean, Chicana and native women. Feminists of colour have developed different strategies against both racism and white ethnocentrism, mostly Eurocentrism. Writing from the vantage point of a post-colonial society, Indian feminists like Chandra Talpade Mohanty and Gayatri Chakravorty Spivak engage in a critical dialogue with postcolonialism, post-structuralism and Western feminism. Confronted with the complexity of all theories, I will address only the Self/Other dichotomy, the notions of centre and margin, hybridity and changed theoretical approaches.

A new field of colonial discourse analysis was inaugurated when Edward W. Said's Orientalism was published in 1978. Said combined Foucault's concept of representation with Frantz Fanon's psychoanalytic investigations of a colonised society to analyse the relationship between textual representation and social practice, between knowledge and power. In Orientalism, Said described the convergence of the textual and political meaning of "representation" and the dangerous consequence in real politics. His critique was new in its focus and in the use of literary material. Frantz Fanon analysed the psychological problems, especially the Self/Other dichotomy, faced by black persons in a white culture. He focused his study more on men than on women. His analysis is based on Jaques Lacan's psychoanalytic concept of the Ego that is not associated with biology but with language and culture. For him, the " $\mathrm{I}$ ", the subject, is created in a fiction-making process: our conception of ourselves, i.e. our identity, is necessarily a fiction which we have to defend against the intrusion of the real world. The subject constructs itself in imitation or in opposition to this image. The title of Fanon's Black Skin, White Masks (1952) refers to the psychology of racial division. Social pressures exerted by a white, racist, colonial culture force the black person to identify his colour with negative associations. The resulting desire to identify with the white oppressor makes it necessary to adopt a white mask. The loss of one's own identity and its recovery is a crucial issue in the process of decolonisation. Frantz Fanon was, however, not only a radical psychoanalyst, but also a political activist, who supported the idea that colonised people can liberate themselves only through violent struggle. At the same time, he emphasised the importance of cul- 
ture for the process of decolonisation. By imposing its values with violence, colonialism had displaced indigenous traditions and alienated the colonised society from their own culture. In this process, colonialism had also disrupted the abilities of cultures and societies to change self-critically and continuously. Although Frantz Fanon recognised the recovery of lost or silenced black history as important aspects of black cultural resistance, he objected to putting too much emphasis on the past, which he judged as another form of racist stereotyping and mystification. He always underlined the importance of change for the present and the future.

In the early 1970s, the term "postcolonial" came to be used in a strict historically and politically delimited sense. It referred to the period after the end of colonialism beginning in the late 1950s and reaching its climax in the 1960s when country after country gained independence from the colonising powers. The dismantling of colonial power did not terminate colonial influence, however, which is now exercised by economic and cultural globalization. "Postcolonial" has ceased to be a historical category. Beginning in the late 1970s, the term "postcolonial" has changed into an ideological concept and a critical disarmament of literary criticism which is connected with migration and the concepts of diaspora, hybridity and nomadism. Migration seems to be one of the most important factors of global change. The international distribution of labour has led to mass migration and social upheaval. Simultaneously, many of the prominent post-colonial scholars and artists living and working in the diaspora of the Western world have connections with the world beyond Europe and America. They link together influences from many traditions and adopt, adapt or reject European models. "Hybridity", once a negative concept of racial distinction has become the metaphor of this cultural mixture. It challenges the notion of a self-contained and homogeneous western culture and stands as a synonym for diversity and multiculturalism if it takes place in a tolerant society. "Nomadism" offers another interesting metaphor for these cultural encounters. Both concepts describe different attitudes toward tradition and integration that should be respected in the politics between minority groups and their host society:

Clearly the nomadic offers an alternative to the hybrid; both respond to the contradictory claims of rival cultural, political or ideological power-centres, but one responds by movements betwixt and between, to and fro, while the other responds in terms of mimicry and mixing, disguises and camouflages. (Hawthorn 2000, 240)

In his essay "Imaginary Homelands" (1992), the Indian author Salman Rushdie expresses his desire that his writing about the phenomena of migration, displacement, life in minority group, cultural transplantation might "For God's sake, open the universe a little more!" (21). He corresponds in this intention to postcolonial scholars and critics and with the poetry of contemporary women writers, the subject of this thesis.

In his book The Location of Culture (1994), Homi K. Bhabha sets the frame and describes the aim of present postcolonial criticism: 
Postcolonial perspectives emerge from the colonial testimony of Third World countries and the discourses of 'minorities' within the geopolitical divisions of East and West, North and South. [...] They formulate their critical revisions around issues of cultural difference, social authority, and social discrimination in order to reveal the antagonistic and ambivalent moments within the 'rationalizations' of modernity. [...] In this salutary sense, a range of contemporary theories suggest that it is from those who have suffered the sentence of history - subjugation, domination, diaspora, displacement - that we learn our most enduring lessons for living and thinking. There is even a growing conviction that the experience of social marginality - as it emerges in non-canonical cultural forms - transforms our critical strategies. It forces us [...] to engage with culture as an uneven, incomplete production of meaning and value, [...] produced in the act of social survival. Culture reaches out to create a symbolic textuality, to give the alienating everyday an aura of selfhood, a promise of pleasure. $(1994,172-173)$

Since Homi K. Bhabha's reflections illuminate the diversity of postcolonial and feminist studies and develop a hopeful vision of the future, I deliberately quoted him at length and will refer to his position several times: the "minority" position develops into a vantage point. Cultural goods from the "margin" promise enrichment, empowering and pleasure. Does Bhabha implicitly consider what I am looking for in women's contemporary poetry on mothering? Is it a wishful illusion to expect these "enduring lessons for living and thinking", "produced in the act of social survival", "to give the alienating everyday an aura of selfhood, a promise of pleasure" within or against "the antagonistic and ambivalent moments within the 'rationalizations' of modernity"? There is, at any rate, a turn to idealism in this form of postcolonial criticism that foregrounds the epiphanies of migration and hybridity and does not pay sufficient attention to the connection between cultural representation, material oppression, and violence. Bhabha's idealisation of these "enduring lessons" and his vague aestheticism remains exclusively the role of a male observer and receiver without attempting or suggesting any intervention. We are reminded of Audre Lorde's angry and precise statement:

Whenever the need for some pretense of communication arises, those who profit from our oppression call upon us to share our knowledge with them. In other words, it is the responsibility of the oppressed to teach the oppressors their mistakes. I am responsible for educating teachers who dismiss my children's culture at school. Black and Third World people are expected to educate white people as to our humanity. (1984, 114-115)

In the 1980s, post-colonial feminists like Chandra Talpade Mohanty addressed two issues: the critique of hegemonic Western Feminism and the formulation of an autonomous Third World feminism. In her essay "Under Western Eyes: Feminist Scholarship and Colonial Discourses" (1991), Chandra Talpade Mohanty distinguishes the following categories of analysis: women as victims of male violence, women and familial systems, women and religious ideologies, women and the development process. She points at homogenising tendencies in Western 
feminist writing that lead to stereotypes and generalisation. Third World women are constituted as a coherent group and associated with the concepts of underdevelopment, oppressive traditions, high illiteracy, rural and urban poverty. This representation leads Western feminists, especially radical and liberal feminists, to the second generalising assumption which regards women's oppression as a global phenomenon. Mohanty's passionate and angry analysis links postcolonialism and feminism:

Western feminist discourse, by assuming women as a coherent already constituted group which is placed in kinship, legal and other structures, defines third-world women as subjects outside of social relations, instead of looking at the ways women are constituted through these very structures. Legal, economic, religious and familial structures are treated as phenomena to be judged by western standards. It is here that ethnocentric universality comes into play. When these structures are defined as 'underdeveloped' or 'developing' and women are placed within these structures, an implicit image of the 'average third-world woman' is produced. This is the transformation of the (implicitly western) 'oppressed woman' into the 'oppressed third-world woman'. While the category of 'oppressed woman' is generated through the exclusive focus on gender difference, the 'oppressed third-world woman' category has an additional attribute - the 'third-world difference'! The 'third-world difference' includes a paternalistic attitude towards women in the third world. Since discussions [...] are conducted in the context of the relative 'underdevelopment' of the third world [...], third-world women as a group are automatically and necessarily defined as: religious (read 'not progressive'), family oriented (read 'traditional'), legal minors ( read 'they-are-still-not-conscious-of-their-rights'), illiterate (read 'ignorant'), domestic ( read 'backwards') and sometimes revolutionary (read 'their-country-is-in-a-state-of-war, they-must-fight!'). This is how the 'thirdworld-difference' is produced. (Mohanty in Williams and Chrisman 1994, 214)

Mohanty's observations are similar to Edward W. Said's affirmations in Orientalism. Consequently, her conclusions on power exercised by knowledge are also not different:

$[\ldots]$ in the context of the hegemony of the western scholarly establishment in the production and dissemination of texts, and in the context of the legitimating imperative of humanistic and scientific discourse, the definition of 'the third-world woman' as a monolith might well tie into the larger economic and ideological praxis of 'disinterested' scientific inquiry and pluralism which are the surface manifestations of a latent economic and cultural colonization of the 'non-western' world. It is time to move beyond the ideological framework in which even Marx found it possible to say: They cannot represent themselves; they must be represented. (Mohanty in Williams and Chrisman 1994, 215-216)

In answer to Mohanty's conclusion, I will digress briefly on the tradition of ThirdWorld feminism and its achievements. Third-world woman writers demonstrate the relevance of feminism for themselves and for their societies. For example, the 
African woman poet Ama Ata Aidoo passionately states that there is no need to be represented:

African women struggling on behalf of themselves and on behalf of the wider community is very much part of our heritage. It is not new and I really refuse to be told I am learning feminism from abroad...Africa has produced a much more concrete tradition of strong women fighters than most other societies. So, when we say that, we are refusing to be overlooked. We are acting today as daughters and granddaughters of women who always refused to keep quiet. We haven't learnt this from anybody abroad. (Aidoo in King, 1996, 240)

One should also not forget that no first-world woman, but four third-world women have been awarded the Peace Nobel Prize during the last two decades: Aung Saan Suu Kyi from Burma who opposes dictatorship, Rigoberta Menchu from Guatemala who fights for the rights of indigenous people, Shirin Ebadi from Iran who fights for democracy and human rights and Wangari Maathai from Kenia who founded the Green Belt Movement and planted 30 million trees in the deserted areas of her homeland.

While Chandra Talpade Mohanty's project is one that dismantles hegemonic Western feminism, Gayatri Chakravorty Spivak's endeavour is the formulation of geographically, historically and culturally based feminist concerns and strategies. Both Mohanty and Spivak overcome the gap between feminist theory and activism by recognising the issues that concern women's movements in post-colonial societies and by accepting generalisations only in particular situations. For Mohanty, generalisations must respect the complex histories and realities. By drawing attention to a particular situation and developing strategies, Spivak has coined the term "strategic essentialism" as a concept for mobilising resistance at a particular moment. Her work and her interests cross disciplinary boundaries and intervene in areas such as postcolonial studies, psychoanalytic theory, linguistics, poststructuralist writing and cultural studies. She is involved with the Subaltern Studies history group in India, with the Indian feminist movement and various Third World movements. Being always aware of the accountability between the writer and her reader, between the teacher and her students, she sets new standards of self-reflexivity in her work as the representative voice of Third-World feminism. Spivak claims that theory must not simply turn to the Third World, but must change its approach. Any movement toward decolonisation must perpetually keep in mind these questions: "Who decolonises? And how?" Spivak applies these considerations to literary criticism by asking: "Who is talking to whom, and why?" The structure of Spivak's thinking is revealed in the title and the structure of her book In Other Worlds. Essays in Cultural Politics (1988). The title's wor(l)d-play points to her interest in the relation between text and world. The progression - One: Literature. Two: Into the World. Three: Entering the Third World - reflects her main interest: the separation of "First World" and "Third World". In her essays, she moves from feminist readings of western canonical texts (Dante, Yeats, 
Woolf) to the politics of interpretation, then to a woman's text from the third world, which she has translated from Bengali and provided with passionate accompanying essays against an uninstructed cultural relativism. In the Spivak Reader (1996), the editors trace the itinerary of her politico-intellectual global activism:

Figuring identities and differences differently - not as narcissistic fixtures expecting mirror-reflections across the globe, but as a call to honor and embrace across impossible differences and distances - is indispensable for any movement toward decolonization. (Landry/MacLean 1996, 5)

Spivak develops her thoughts in her essay "Echo" with a complex reading of the Narcissus story (in Donna Landry and Gerald MacLean 1996, 175-202). Feminism involved in decolonisation has to overcome its narcissism and self-fixation in order to form a new ethic: "Ethics are not a problem of knowledge but a call of relationship (where being without relationship is the limit case)" (1996, 190). She applies these thoughts to her analysis of literary texts. Spivak maintains that the private and the public life of a citizen of a recently decolonised nation can be totally at odds with each other. Literature deals with these fractured positions. In her multi-levelled reading of culturally different texts, the author draws our attention to these difficulties. In her essay "How to Teach a 'Culturally Different' Book," she gives advice for a responsible reading of an "Indo-Anglican" text (in Donna Landry and Gerald MacLean 1996, 237-266). She examines the use of English in relation to Indian vernaculars and the cultural institution of a temple dancer from various perspectives, which characterise the social status of the male protagonist and the class stratification of the Indian society. Finally, she reads the film version of this novel as an indigenous translation from English to Hindi and from an elite to a popular text. Her reading shows how difficult it is to define national identities and ethnic minorities and cautions against precipitate judgements and conclusions. Her example will direct my work with culturally different poems on mothering.

In her companion essays to the texts of the Bengali woman author and political activist Mahaswete Devi, whose texts she has been translating, she draws attention to the place of women in Indian society (in Donna Landry and Gerald MacLean 1996, 267-286). Devi's political and fictional work has moved into the politics of Indian tribals and outcasts. The women of her fiction are singular figures of the "gendered subaltern". Her fiction takes in new social movements - such as non-Eurocentric ecological movements and various women movements against reproductive engineering and international population-control policy. In her analysis of Devi's texts - especially her short story "Pterodactyl" - Spivak is drawn into her political and social activities and pushed to ethical instructions:

This relationship, a witnessing love and a supplementing collective struggle, is the relationship between her 'literary' writing and her activism. Indeed, in the general global predicament today, such a supplementation must become the relationship between the silent gift of the subaltern and the thunderous imperative of the 
Enlightenment to the 'public use of Reason', however hopeless that undertaking might seem. One filling the other's gap. (1996, 276-277)

Spivak draws a similar moral imperative from Subaltern Studies. In this study group, Indian historiographers started to pay attention to the activities of Indian peasantry in the struggle for Independence which are not mentioned in official colonial history. They represent a group without class consciousness and without a voice. In one of her most influential essays "Can the Subaltern Speak?" (in Patrick Williams and Laura Chrisman 1994, 66-111), Spivak analyses the social position of women as gendered subalterns and demands to trace their suppressed or erased voices. The interpretation of their silences may, however, continue their voicelessness, when the Western scholar takes over the subaltern's voice, speaking for and about her without, if possible, having spoken with her before. Spivak leads the reader of culturally different texts to an attentive, multi-levelled analysis which is inspired by self-reflective respect and conscious of its temporary validity. This reading should lead to political thinking and a decolonisation of the mind of both parts, which is required for political action in order to change the world.

Spivak's work has transformed the cultural debate in the western academy and its relation to the non-West. These are the main points of her lesson for me and my project: Spivak clearly distinguishes between the three concepts of language, world and consciousness. Her analysis reflects the dialectic between the real and the imaginary and the different forms of theory she applies. Reading these texts, we are not asked to find our own identity but to think about the inherent political consequences. Her analysis of literary texts alongside historical documents has challenged feminist assumptions about the representation of third-world women. Yet, Spivak's theorising is always directed at intervention, at attempting to change the world. For Spivak, the community of women can only come into existence after the recognition of difference between women. How do we move from analysing the differences to actively redefining the common bonds? Spivak's analysis of literary texts suggests the possibility of communication between women as the basis for politics. It is necessary to find these communicative bonds through which a political dialogue can start and remains viable. Spivak transforms the discourse of theory and directs theory to practice and politics. In her professional status as teacher her attentiveness and endeavour coincide with Chandra Talpade Mohanty's pedagogy of dissent which she develops in her book Feminism without Borders - Decolonizing Theory, Practicing Solidarity (2003):

I think feminist pedagogy should not simply expose students to particularized academic scholarship but it should also envision the possibility of activism and struggle outside the academy. [...] I look to create pedagogies that allow students to see the complexities, singularities, and interconnections between communities of women such that power, privilege, agency and dissent can be made visible and engaged with. (2003, 243-244) 
Returning to the metaphor of edge and borderland in my introduction, a new perspective develops. A decolonisation of theory, as well as sensitive and attentive theoretical approaches overcome the edge between theory and practice and put the possibility of a communicative dialogue as the basis for politics on the agenda. How does feminism open itself to this communicative bond of women? Spivak and Mohanty, both address "the community of women". But the question occurs of how to characterise, to theorise and to politicise this community. Some feminists questioned women's characterisation through their biological or social mothering. Others endow women with capacity for mutual connections which is traced back to maternal inclinations. In her essay "Contingent foundations: Feminism and the question of "postmodernism"' (1992, 3-22), Judith Butler supports the political necessity to speak as and for women. At the same time, however, she rejects a universal or specific content of the category of women. The recourse to or the emancipation from mothering remains a central concern of feminist discourse and will be the topic of a vivid argumentation for which the next chapter provides the theoretical frame. 


\section{Mothering - a Human Experience in Practice and Theory}

Due to my personal experience as a physician working with mothers and children in slums and refugee camps in the Third World, I reject any romanticising concept of the borderland that might have been suggested in the preceding chapters. We must not forget that borderlands are the result of borders that have forced people to flee economic and/or military power. Borderlands remain a dangerous no man's land marked by tensions and violence as well as by resistance and solidarity. Poverty and war force women to practice different forms of mothering because they are often left alone with their children. Men, as husbands and fathers, are forced to join the international labour force or the army. They abandon their families for long intervals or forever. Women must live together and share their roles as mothers and bread-winners of their extended families. In Africa, many grandmothers at present have to mother their grandchildren because their daughters died of Aids. Being a mother exceeds the biological foundations of mother and child. Women take care of their own children and mother many others who need it. Substitute mothers are mostly to be found within the close family. Among African, Caribbean and Latin American societies, however, there has always been the other mother. Grandmothers, aunts, older siblings and neighbour women out of necessity fulfil the mothering role. Interestingly, not only older sisters, but older brothers are now beginning to fulfil their duties as well. Mothering includes community responsibility and is based on cultural perceptions of kinship. The conception of mothering varies, however, not just between different societies and different cultures, but also in particular times of change. Mothering is today regarded as a cultural and social phenomenon and is explored from a variety of perspectives and disciplines. The following theoretical considerations can only be selective. They build up a thematic frame for the analysis and discussion of poems on mothering. 
In the 1970s, predominantly liberal and radical Western feminists began to oppose the glorification of motherhood in American post-war society and criticised the disadvantages forced on mothers by the social arrangements for childcare. In 1976, Adrienne Rich, poet, mother of three sons, radical lesbian feminist, published her study on motherhood Of Woman Born: Motherhood as Experience and Institution in which she criticised the institutionalisation of motherhood and its control by men: a male medical establishment controls the birth process; men economically dominate the family, men decide within the educational system. The patriarchal system gives women all responsibility but no influence. Rich rejects neither motherhood nor criticises children. Rather, she rejects the prejudice that only idealised motherhood, primarily defined by men, is a subject for literature. This she calls a flat and inauthentic version of the mother-child relation. Rich discusses the theory of motherhood in prose and expresses her maternal thinking and feeling in poems on social and political issues. She suggests female bonding - the societies of women - as an alternative to the oppressive experience of motherhood in an institution under male dominance.

In 1978, US feminist and psychoanalytic Nancy Chodorow included men in childrearing and proposed shared parenting. Her book The Reproduction of Mothering is based on a psychoanalytic reconstruction of mother-child relations. According to her speculations, women bear almost exclusive responsibility for child-rearing, and this is the main reason for men's power and women's restriction to nurturing roles and social powerlessness. All education predominantly carried out by mothers will rear daughters "with mothering capacities and the desire to mother" and "sons whose nurturing capacities and needs have been systematically curtailed and repressed" $(1978,7)$. Thus gender inequality is the result of a wrong socialisation process carried out by mothers. Chodorow suggested shared parenting as a way of breaking out of the infinite reproduction of rigid gender roles, a cycle comparable to and responsible for the repetition of war and death. Pessimistic critics questioned, however, whether dual parenting alone could change the male personality in the necessary way. In spite of these apprehensions, these ideas have been influential for the concept of maternal thinking and women's involvement in peacemovements world-wide.

In 1989, Sara Ruddick published her book Maternal Thinking. Toward a Politics of Peace. The first attempt to describe, from a philosophical perspective, the thinking that grows out of the work mothers do. Influenced by philosophical relativists like Jürgen Habermas and Ludwig Wittgenstein, she is convinced that all thinking is rooted in and shaped by the activities in which people engage. In her convictions, she resembles Susan Stanford Friedman who influenced my study with her book Mappings, Feminism and the Cultural Geographies of Encounter (1998). For Ruddick, "maternal thinking" embraces reflection, judgement and emotion developed out of "maternal practice". Maternal practice has to meet three principal demands: preserve the child's life, foster the child's growth, and educate the child 
to be an adult who is acceptable to the next generation. For her, the daily work of childrearing with all the care, attention, and patience it requires, constitutes a microcosm of world relations. Often mothers may face danger and disappointment and be prone to frustration and depression. Ruddick suggests constant learning, humility and resilient cheerfulness as virtues to overcome these risks and to develop the intellectual capacity of disinterested love. Ruddick emphasises the importance of intellectual struggle for this process. Her primary goal is to give this transformed maternal thinking the respect and the self-esteem in the public realm which it deserves. She wants to establish it as the foundation for a political movement to promote world peace. She concludes her book with the following outlook:

Now so, my story goes, a feminist maternal peace politics can transform maternal practice. [...] Many politics are needed, many wills, many moral and intellectual inventions. A maternal peace politics is one story. It makes a beginning that like birth itself, revives human hopes as old and as indestructible as war. $(1989,251)$

Sara Ruddick's philosophical elaboration of maternal thinking can be transferred to women's poetry. Women's poetry on mothering and children becomes a maternal politics: a protest against discrimination, oppression, violence, hunger and war.

In contrast to Sara Ruddick, Caroline Whitbeck's argues in her essays, "The Maternal Instinct" (1972) and "Afterword to the Maternal Instinct" (1982), that maternal attachment and affection are not only the result of an intellectual socialisation process but arise from "biological differences and experiences of pregnancy, labour, childbirth, nursing and postpartum recovery". She draws attention to the importance of the body for women and the bodily experience of mothering. Her considerations point at the universal features of mothering which are grounded in biology and include the long gestation inside the mother's body and the phase of nursing. Additionally, there are universal aspects, regarding the prolonged dependence of infants and children due to the physical weakness and fragility of the infant and to the prolonged development of intellectual and emotional capacities necessary for socialisation.

Shifting attention from personal to political reflections on mothering, Ann Ferguson moves away from the mother as a biologically defined and stable category. In her essay "Conceiving Motherhood and Sexuality: A Feminist Materialist Approach" (1982), she demonstrates that human societies have always developed different types of family and kinship networks. The nuclear, heterosexual, bourgeois family is not a universal institution nor are affectionate interactions between children and parents. She shows how the conception of motherhood, the value attached to it in different historical periods and in different societies, changed women's and men's role in society and influenced colonial politics. At the time of her study (1982), Ferguson observed an increasing crisis in motherhood in the white nuclear heterosexual family due to the institutionalisation and male domination of reproductive practice and the educational system plus the increasing legal 
power to intervene in family affairs. (In the meantime, however, reproductive medicine and the educational system are increasingly dominated by women. The situation in "Third World" societies is different.) For her, this isolates mothers from their children and from supportive bonding with other women. She argues for changes in motherhood and opts for networks of women and children (social motherhood) or networks of men, women, and children (social parenthood). As already described in the preceding chapter these alternative family forms, regarded as modern achievements of western societies, are common practice in other cultures and look back on a long tradition. Besides these changed modes of familial organisation, our western societies now more and more accept the 'single mother' and her experience of mothering. On the one hand, western societies adopt family forms of the Third World. On the other hand, the evaluation of motherhood is under critique in many Third World societies similar to the development in the western world. In traditional societies, motherhood was crucial to a woman's social status. The role of the mother was universally imposed upon women as their main identity. Postcolonial literature written by men has treated mothers as symbols of earth, nation and state and idealised motherhood. In contrast, postcolonial women writers have begun to question this romanticised view of motherhood and to present details of women's lived experience in different cultures and societies.

Modern theories like postmodernism and post-structuralism carried the critical debate still a step further. They deconstructed the notion of the "real body" and of women's "experience". To deconstruct does not mean, however, to negate a concept but to regard it within other contexts and to open it for various political aims. My thesis directs its focus from this debate about "motherhood", whether biological or social, to a characterisation of "mothering" that aims at both respecting and transcending theories and at contradicting political nihilism. 


\section{Why a Study about Poetry - not the Novel or Drama - on Mothering?}

This study has been written by a lover of poetry who is also interested in theories of literary criticism: feminist, postcolonialist, postmodern, poststructuralist. Yet this project developed not only out of a personal preference, but also out of an accidental literary encounter. In her essay "Beyond the Millennium: Black Women's Writing” (2000, 71), Susheila Nasta criticises the missing scholarly attention to Black women's writing. In general, her critique is no longer true, but her main concern, "the whole question of the voice of the writers and the significance of that voice in relation to theory", still needs to be respected. She objects to critics who erase or silence the author by adopting her story, by just retelling it.

How shall I outline the criteria that determine my choice of poems? It is not possible to consider in detail the essence and the function of poetry. This endeavour would lead to general questions of the nature of art. I can only epitomise some aspects that have been influential for my work. Poetry is, to begin with, the purposeless exploration of universal and individual human conditions. It expresses feelings and emotions, refines our sensibility and enlarges our consciousness. Beyond any intention, it communicates something new in a new language. But poetry can also have a deliberate social and political purpose. In chants, for example, it often serves as consoling, protecting and healing remedy; in epics, it combines the present with an often mythical past; in religious hymns it serves a public ceremony. Confronted with the painful past and presence of postcolonial societies, one should not forget protest songs as well as poetry of defiance and longing. Since this poetry is mostly short and can be learnt by heart, it is still more effective as a political tool than prose. All these characterisations have in common that poetry conveys a message that cannot be dealt with in prose. The poetic language is distinct from the ordinary language used for our daily conversation, because it stands for potentially all possibilities of language. Poetic words offer various connotations, different significations. The hearer has to notice language in its use, its sound and 
rhythm instead of moving directly to the reality or the abstractions to which the words refer. In Revolution in Poetic Language (1974), the French linguist and psychoanalyst Julia Kristeva developed the concept of the poetic dimensions of language "that breaks the laws of a language censored by grammar and semantics, and at the same time, is a social and political protest" (Kristeva in Moi 1986, 36).

A woman as a reader of texts by women should also bear in mind Hélène Cixous's concept of feminine writing. Her idealising metaphor for writing comes from the maternal body and its generosity. She uses the myths of Medusa and Medea as paradigms for female experience. For Hélène Cixous, the female body, female sexuality and women's writing are generous and subversive; whereas men are aligned with ownership, property, the economy of exchange and rigidity. This feminine writing, she argues, overcomes the self-referential masculine viewpoint and brings into existence alternative forms of relation, perception and expression. In this sense, it challenges the patriarchal and capitalist system and is revolutionary. Women's writing about their personal experience was criticised because of its subjectivity. Cixous puts, however, emphasis on subjectivity: "There is no true art which does not take as its source or root the universal regions of subjectivity" (Sellers 1994, XVII). She proves her contention with Shakespeare, who remains "the most modern of authors", because "he has brought hundreds of individuals into the world, all exemplars of powerful subjectivity" (XII). The concept of a feminine language and writing has, however, often been criticised by women and men. The first epigraph that precedes my dissertation - a quotation from Shakespeare's play Troilus and Cressida - may serve as an early and nicely put example that anticipates the main objections. The speaker Ulysses finds Cressida's body language devious and immoral.

Poetry as purposeless exploration of a human condition and poetry with a function, these aspects have influenced my choice of poems on mothering. Additionally, I have been looking for poems that take into consideration the issues of the theoretical part. I wanted to find out whether and how these poems depict the impact of gender, race and ethnicity on mothering, and whether and how these intersections reflect the concepts of the theoretical part like, for example, "maternal practice", "shared parenthood", "womanist", "strategic essentialism".

In my introduction, I already mentioned that I did not find precursors for this kind of work. 


\section{Framework for a Pioneering Project}

In spite of scholarly claims to keep a sufficient distance from subjectivity, it is sometimes necessary to be personal. In my case, it is even more important because it is my personal experience that initiated this thesis and that shall be used to bridge the gap between theory and praxis. At this stage of my work, I will look back and forward, expanding the ideas of my introduction, commenting on the first part of theory and mapping the part on poetry.

This thesis is organised around two interlocking issues. The theoretical part outlined how the emphasis on difference in recent feminist theory, especially Black and postcolonial, corrects stereotypes of gender, race, ethnicity and opens the prospect for more diversity, yet seems to paralyse feminism's force as a social movement. During my work as a volunteer doctor in Third World countries, I experience daily the singularity of human life, the vulnerability and fragility of soul and body and the need for protection. Reading poetry by women from the countries where I have been working, often life-stories and faces of my patients reappear in my memory. Through their own poetry, women represent themselves and their own experiences, especially their experience of mothering. Mapping the poetic terrain for this topic means retrieving the complexity and subtlety of motherhood and maternal activities. It contains the participants, mothers and children, the biological facts of pregnancy, giving birth and nurturing. It entails fostering growth, inventing strategies of protection, caring for shelter, maintaining homes, training and introduction of a child into different societies. In the colonial and postcolonial context, men treated women more frequently as symbols than as living individuals. Patriarchal myths and male-dominated movements towards independence and nationalism, often created stereotypes of the mother: the fertile "Mother Earth" in African literature and female goddesses in "Mother India". But it would be one-sided and unjust not to mention beautiful examples of this genre. I insert some lines of the love poem "I will pronounce your name" by the Sene- 
galese poet Leopold Sedor Senghor. The poet uses images from African nature and landscape to praise the beloved woman, who appears as a symbol of Africa:

\section{I will pronounce your name ${ }^{1}$}

I will pronounce your name, Naett, I will declaim you, Naett!

Naett, your name is mild like cinnamon, it is the fragrance in which the lemon grove sleeps,

Naett, your name is the sugared clarity of blooming coffee trees

And it resembles the savannah, that blossoms forth under the masculine ardour of the of the midday sun.

There are no stereotypes in this praise of African beauty in poetry.

The women writing poetry in English usually belong to the upper and middle classes of their societies. Their poems often take a critical stance against stereotypes and idealisation of motherhood. They speak about the joys and pains of motherhood. They challenge the traditionally prescribed role of women in both the postcolonial society and the diaspora from an apolitical to a militant feminist position. The influence of tradition plays an important role for the relation between ethnic minorities and their host societies. The future of multicultural societies depends on the impact of traditional categories and hierarchies. Are they inclined to hybrid or nomadic models of community life or are they able to find totally different forms? Women as mothers and teachers of their children address these questions in their poetry with anxiety and despair, but also with hope.

The selected poems represent the twin-goals of poetry of how to teach about a subject and to delight in the poetic form. My analysis of English poetry from three postcolonial contexts also draws attention to the characteristics of anglophone poetry around the globe - their differences and similarities. This comparison is based on the aspects of Black aesthetics described in the theoretical part in the chapter on difference concerning race (p. 17). Poetry on "mothering" pulls together feminist discourses on differences of gender, race, ethnicity outlined in the theoretical part. This project will introduce poems that deal with aspects of mothering and draw attention to a global language of poetry. Even though my procedure is apparently personal and impressionistic, the juxtaposition of English poetry from three postcolonial contexts transcends the local and casual. These poems and their analyses strive to advocate the cause of mothers and children that is not otherwise advocated so urgently.

Doing research for both parts of my thesis, I experienced how much the political and social situation is already at play in terms of publishing, distribution, reviews etc. In this context, one can understand feminism's critique. Women writers, especially women poets from postcolonial societies, have been underrepresented in existing anthologies for a long time and marginalised or neglected in

\footnotetext{
${ }^{1}$ Senghor, Leopld Sedar. „I will pronounce your name.“ A Selection of African Poetry. Ed. E. Senan Vincent. Burnt Mill, Harlow, Essex, England: Longman, 1982. 28.
} 
critical discourse until today. A striking imbalance also exists in the availability of books and sources on theory and on poetry. Our network of university libraries provides hundreds of books to choose from for theory, but the choice of primary literature is scarce. My thesis is an example of this fact. The overview of feminists' critical theoretical writing epitomises some thousand easily available pages covering at least five decades. For poetry, however, a still small window of publication has begun to open only since the late 1970s. I will refer to the availability of poetry in the appropriate chapters. Looking at both issues of my thesis and regarding the availability of literary material, I am inclined to compare it to David's challenge to Goliath. His tools are his brain and the small stone of poetry that he uses for his sling against the physical presence of Goliath.

Collecting contemporary poems on mothering, I looked back at earlier poems by women on this issue. The insertion of two early American poets does not intend to prove a historical development. My intention is rather to challenge the pretension of the twentieth century women's movement. They were not the first to make the personal political. Additionally, I want to draw attention to the different voices of women's poetry.

Anne Bradstreet (1612-1672) was the first woman to write from a British colony. Although her roots were English, she is North-America's first woman poet. As a Pilgrim mother in a privileged position within a socially prominent family, she wrote poetry while rearing eight children, frequently ill, yet keeping house at the edge of the wilderness. This was an act of great vitality and self-assertion. She wrote political, public and domestic poems. She described herself with modesty and pride in her biological and social role as mother protecting, teaching and educating her children, like a hen with her chickens. With her depiction of mothering, she introduced the topic of mother-child-relationship to English poetry. In her autobiographical poem, "Before the Birth of One of Her Children" (Letter to Her Husband) ${ }^{2}$, she writes about her fear of dying in childbirth. She also asks for protection of her children and memory of her writing should she die.

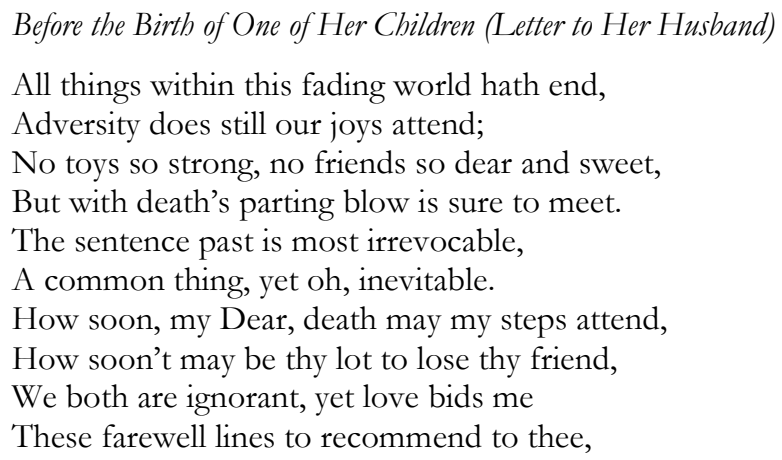

\footnotetext{
2 Bradstreet, Anne. „Before the Birth of One of Her Children“. The World Split Open. Women Poets
} 1552-1950. Ed. Louise Bernikow. London: The Women’s Press, 1979. 192-193. 
That when that knot's untied that made us one,

I may seem thine, who in effect am none.

And if I see not half my days that's due,

What nature would, God grants to yours and you;

The many faults that well you know I have

Let be interred in my oblivious grave;

If any worth or virtue were in me,

Let that live freshly in thy memory

And when thou feel'st no grief, as I no harms,

Yet love thy dead, who long lay in thine arms.

And when thy loss shall be repaid with gains

Look to my little babes, my dear remains.

And if thou love thyself, or loved'st me,

These $\mathrm{O}$ protect from step-dame's injury.

And if chance to thine eyes shall bring this verse,

With some sad sighs honour my absent hearse;

And kiss this paper for thy love's dear sake,

Who with salt tears this last farewell did take.

Poetic form and content of this poem induce me to question the preceding summary of Bradstreet 's life and work Her poem is written in regular heroic couplets, the preferred mode of English poetry of the seventeenth and eighteenth century, which was frequently concerned with noble attitudes and sententious moralising. John Dryden and Alexander Pope used this form which requires advanced poetic skills:

Heroic couplet: a rhymic couplet of iambic pentameter, often 'closed', that is containing a complete thought, with a fairly heavy pause at the end of the first line and a still heavier one at the ende of the second. Commonly, there is a parallel or antithesis within a line or between two lines. It is called heroic because in England, especially in the eighteenth century it was much used for heroic (epic) poems. (Barnet 1997, 612)

This form stood as a challenge for Anne Bradstreet. In writing heroic couplets, a woman aimed at the authority of the male masters. Anne Bradstreet always assumed the modest poetic persona in her poems which was standard for Puritan women's writing.

Thematically, four parts can be distinguished. The first part anticipates death in general terms; the second continues with an intimate voice, addresses her husband and expresses their mutual love and friendship; the third speaks in a humble and modest tone about her person, her faults and recommends her virtues to memory. Her self-sacrificial stance is disturbing, however. The final section envisions the future of her family without herself: her husband will be remarried, her children protected against perhaps an evil stepmother and her verse shall be the remembrance of her love. She wants to be remembered as wife, mother and poet 
and identifies these roles in her poem. The poetic letter, "To My Dear Children"3, speaks about her attitude toward motherhood:

\section{To My Dear Children}

This book by any yet unread, I leave for you when I am dead, That being gone, here you may find What was your living mother's mind. Make use of what I leave in love, And God shall bless you from above.

A.B.

\section{My dear children,}

[...] It please God to keep me a long time without a child, which was a great grief to me and cost me many prayers and tears before I obtained one, and after him gave me many more of whom I now took the care, that as I have brought you into the world, and with great pains, weakness, cares, and fears brought you to this, I now travail in birth again of you till Christ be formed in you.

[...] Now to the King, immortal, eternal and invisible, the only wise God, be honour, and glory for ever and ever, Amen.

In this letter, she tells her children about her health problems from childhood on. She suffered from bouts of rheumatic fever, lameness, fever, fainting. It is understandable that much of her writing concerns the human body, illness and mortality. But Puritanism had a far more rigorous influence on her life and work, and the greatest part of this testament to her children deals with the duty to submit to the will of God and the need to accept this will as heavenly love.

By connecting both poems, it is possible to outline the poet's understanding of motherhood. Anne Bradstreet accepts motherhood as her biological role given to her from God. The responsibility for mothering lies with the biological mother for whom the role is natural and a mission of moral imperatives. It has meant subordination to others, unconditional love and doing for others. In some of her poems, Anne Bradstreet seems to be a covertly secular poet, but in both her letters to her husband and her children she cannot free herself from religious convictions. The Puritanism dominated this society and dictated the relationship between wife and husband, mother and children and, of course, the education. The impact of religion on family life and mothering remains a topic in contemporary women's poetry today. Our next woman poet lived in a time of social and political upheaval and threw herself into the public sphere on behalf of black mothers.

\footnotetext{
${ }^{3}$ Bradstreet, Anne. "To My Dear Children". The Harper American Literature. Second Edition, Volume 1. Eds. Donald McQuade, et al. New York: Harper Collins College Publishers, 1994. 187-190.
} 
Frances E. W. Harper (1825-1911) was the daughter of freed slaves. After the Civil War, she campaigned for education for freed slaves and wrote poems and articles for anti-slavery publications. Most of her income was donated to fugitive slaves and the underground railroad. She must have been an excellent public speaker if she used all the techniques of rhetoric which she applies to her poem. Frances E. W. Harper was a woman who had learned the meaning of activism in the anti-slavery movement, for which she wrote effective speeches and poetry like the following (Lauter, ed. 1998, 686-696). My analysis is based on a shortened version taken from Bernikow's anthology The World Split Open. Women Poets 1552-1950. I will point at the risk of using anthologies in the appendix of this chapter.

The Slave Mother ${ }^{4}$

Heard you that shriek? It rose

So wildly in the air,

It seemed as if a burdened heart

Was breaking in despair.

Saw you those hands so sadly clasped -

The bowed and feeble head -

The shuddering of that fragile form -

That look of grief and dread?

She is a mother, pale with fear,

Her boy clings to her side,

And in her kirtle vainly tries

His trembling form to hide.

He is not hers, although she bore

For him a mother's pains;

He is not hers, although her blood

is coursing through his veins!

He is not hers, for cruel hands

May rudely tear apart

The only wreath of household love

That binds her breaking heart.

This poem starts with questions asking for the poem's protagonists: the mother and the child. Three ballad stanzas each rhyming in their second and fourth lines, frame a stanza of eight lines which visually seems to demonstrate the connection of mother and child who are torn apart in the last stanza. The slave mother is in a totally different position than the poetic persona of the white Puritan Anne Bradstreet. She is the biological mother ("her blood is coursing in his veins."). But as slaves, she and her boy, who is not even called her son, are the properties of the slave owner who might also be the biological father of the boy. ("He is not hers,

\footnotetext{
${ }^{4}$ Harper, Francis E. W. "The Slave Mother". The World Split Open. Women Poets 1552-1950. Ed. Louise Bernikow. London: The Women's Press, 1979. 192-193.
} 
although her blood is coursing through his veins!'). It is customary to associate mourning with flowers and wreaths. The imagery of wreath in the last stanza and the shriek of the first stanza could suggest that the poem refers to the Garner incident from 1856. Margaret Garner was a fugitive slave mother from Ohio who killed her three-year-old daughter to prevent her from slavery. Amid the gunfire of the slave catchers, this mother also tried to kill her other children before she attempted suicide. In the poem, mother and child appear in a moment of utmost terror and despair ("Heard you that shriek? [ ] It seemed as if a burdened heart // was breaking in despair.") In the last stanza, there is only an allusion to the boy by means of the wreath "that binds her breaking heart". The Garner incident was reported and debated in most of the antislavery acts and newspapers to help further the cause of abolition in the United States. This tragedy also inspired Toni Morrison to write her novel Beloved because she was fascinated by the love of a mother that expressed itself in murder. Let us now listen to a contemporary and highly different voice.

Maud Sulter is a Black British woman writer. She was born in Glasgow in 1960. She is a journalist, publisher, photographer who also writes fiction and poetry. In her work, she cultivates her African roots and struggles against the hostility of a racist society. Her poetry collection As a Black Woman (1985) ${ }^{5}$ won the Vera Bell Prize.

\section{As a Black Woman}

As a black woman

the bearing of my child

is a political act.

I have

been mounted in rape bred from like cattle mined for my fecundity

I have

been denied abortion denied contraception denied my freedom to choose

I have

been subjected to abortion injected with contraception sterilised without my consent

I have

borne witness to the murders of my children

by the Klan, the Front, the State

\footnotetext{
${ }^{5}$ Sulter, Maud. As a Black Woman. London. Akira Press, 1985.
} 
I have

borne sons hung for rape

for looking at a white girl

I have

borne daughters shot

for being liberationists

As a blackwoman

I have taken the power to choose

to bear a black child

- a political act?

As a blackwoman

every act is a personal act

every act is a political act

As a blackwoman

the personal is political

holds no empty rhetoric.

This poem starts with the powerful declaration that for a black woman even the intimate experience of bearing a child is a political act. The speaker, a collective "I", explicitly states her connection with her child. The following six stanzas, which are identical in language and layout, explain and justify this position. They enumerate the crimes afflicted to many black women during slavery, segregation and in a modern racist society. They speak about the abuse of body and womb forced today upon a black woman through rape and the violence and contradictions in reproductive technology. In her poem, the body remains central to gender oppression and racism. Then she speaks about the murder of black children. After this testimony of pain, anger and hatred, the poem puts the statement from the beginning into question in order to provoke a stance of self-assurance and independence. Against all inflictions, a black woman regains her strength and reclaims selfhood and power. "The personal is political", this position of second wave feminism and the Women's Rights Movement is not a slogan for a "blackwoman" but reality, and she turns it into one of her tools for survival.

These three poems are stylistically wide apart. They encompass conventional, affective-sentimental and declamatory agitprop poetry. Contemporary women poets from anglophone postcolonial contexts have enriched the traditional English poetic language in their own way. Let us now listen to their voices.

Appendix: I am grateful to Professor Göske for criticising my interpretation of E. W. Harper's poem 'The Slave Mother". Bernikow's anthology did not prove it as a shortened version. It was also not included in my copy of the third edition of the Heath Anthology of American Literature from 1998. The complete poem has five more stanzas. The stanza of eight lines, from which I drew my unfounded conclusions, 
has originally a stanza break. The complete text proves that the poem deals with a desperate slave mother whose small son is torn away from her.

I apologise for this mistake. At the same time, I want to point at the risk of using anthologies that approach authors according to the expectations, the need and the preferences of the editors and expected readers. For my dissertation, I was often dependent on anthologies because single publications were not available. Whenever I shortened a long poem, I indicated the omissions. 


\section{English Poetry by Women from India and the Diaspora: Kamala Das - Eunice de Souza - Melanie Silgardo - Sujata Bhatt - Imtiaz Dharker}

Most women poets writing in English from both the Indian sub-continent and the diaspora can be regarded as postcolonial authors whose work is directed against the influences of colonialism and imperialism and responds to issues of language, identity and race. Likewise, most of them can be recognised as feminists addressing gender oppression, and dominant traditions of class, caste and religion. Women living in the diaspora also write about the impact of foreign cultures and societies on their lives. In India, feminism developed in the late 1960s and influenced the already existing women's movements. In the late nineteenth century, women reformers, e.g. Pandita Ramabai (1858-1922) and Rokeya Sakhavat Hossein (1880-1932), worked in the field of women's education and set up schools. They also started social reforms for mother and child welfare and medical service. They pushed through changes in legislation for child-brides, wives and widows, e.g. Widow Remarriage Act, Civil Marriage Act, Age of Consent Act, but in spite of their achievements, these pioneers have been criticised because they worked within the existing patriarchal system instead of reordering it. Rokeya Sakhavat Hossein, however, envisaged its overthrow in her famous utopian fantasy "Sultana's Dream" (1905). This witty, ironic, brilliantly written short story, which is regarded a bedrock of Indian feminist writing, describes a world in which men are kept in seclusion and women govern the country. This wonderful country is without war or crime, since science is only used to serve humanity. Women's work, like cooking, gardening, caring for the family, is highly esteemed.

In her fictional memoirs Meatless Days (1989), the Indian feminist theorist and literary critic Sara Suleri announces: "(T)here are no women in the third world" $(1989,20)$. This famous statement raises questions. Does it refer to the alleged invisibility and silence of Third World women or to the reductive construction of the Third-World woman? Probably the author indicates both. Prominent and 
audible voices of Indian feminist theorists and literary critics immediately spoke out against this assessment. Sara Suleri herself, Chandra Talpade Mohanty and Gayatry Chakravorty Spivak - to mention only a few - gained attention worldwide. Until the early 1990s, women's texts had been almost entirely forgotten; but fortunately, in the last two decades the following three anthologies recovered Indian women's writing. In 1991, Susie Tharu and K. Lalita published Women Writing in India. In 2002, Eunice de Souza and Lindsay Pereira edited Women's Voices Selections from Nineteenth and Early-Twentieth Century Indian Writing in English, which was followed in 2004 by Eunice de Souza's Purdab - An Anthology. The extent and the originality of these texts contradict both implications of Suleri's statement. The same applies to the essay collection Infinite Variety - Women in Society and Literature (1994). Firdous Azim and Niaz Zaman, feminist literary critics from Bangladesh, address the implication that the Third World is a reductive construct and deny the stereotyping representation of women already contained in Suleri's title. All these volumes deal with a wide range of women's issues and prepare the aesthetic, mythological, symbolic and political foundations for research on contemporary Indian women's poetry.

Women Writing in India (1991) is an anthology of more than one thousand pages in two volumes. It encompasses women writers from possibly the earliest known anthology of women's literature anywhere in the world, that contained the songs of Buddhist nuns in the $6^{\text {th }}$ century B. C., to contemporary writers. These women have been writing in Pali, Tamil, Kannada, Marathi, Bengali, Gujarati, Hindi, Teluga, Persian, Urdu. Translated extracts and poems enable us to become acquainted with a small part of this large and sophisticated literary production. Since India's religions, ancient philosophy and ethics are often addressed in women's poetry, some aspects have to be elucidated. Secular poetry used an extended symbolism of seasons, places, plants and animals to connect mood and emotions with landscapes, flowers and seasons. The woman's body is sensuously described: "her skin like young mango leaf, her dark hair musk with the sent of jasmine" (Tharu, Lalita 1991, 71). Interestingly, Bengali poetical works of the medieval period already reflect on women's inferior social position and express an incipient feminism. Janabai (ca. 1298-1350) wrote: "Let me not be sad because I am born a woman / In this world; many saints suffer in this way" (Tharu, Lalita 1991, 82). Women's poems celebrate physical, sexual and divine love, often blurring the boundaries between them. In Hinduism, the Maha Devi, the Great Goddess, is Mother and endowed with creative, nurturing, healing and protecting power, but she can also be destructive. She combines active and passive, evil and good character traits which find their personification in the fearsome Durga, who destroys evil, in the dreaded and merciless oppressor goddess Kali, the benevolent Parvati and the fortunate Lakshmi. Contemporary Indian women's writing aims at subversion or revival of these models. Examples from medieval Bengali poetry reveal that Bengali women engaged in a variety of activities. Women are described as 
producers of food, meat-sellers, spinners, weavers, basket makers, dancers, musicians and in many non-traditional roles, such as copyists, boat-women, armed royal guards. This poetry casts new light on women's social and economic conditions and works as an incentive for present women.

Toru Dutt (1856-1877) was the first woman poet in India to write poetry in English and French and translate Hindu myths and poetry into English. She had a Christian background and was educated in Cambridge. The Dutt Family Album, a collection of literary works by family members reveals the connection with English literature. In Women Writing in India, the first entry about an author writing in English concerns Pandita Ramabai Saraswati (1858-1922), a well-known scholar and humanist as well as a social and political reformer. Following Saraswati, two early twentieth century women writers prepared the ground for women's writing in English. Cornelia Sarobji (1866-1954) and Sarojini Naidu (1879-1949) both attended universities in Britain and were associated with women's politics during the last period of British colonialism. In her work as Legal Adviser to the Government's Court of Wards, Sarobji pursued a pro-British and anti-nationalist course. The titles of her books Love and Life Behind the Purdah (1901), Sun-babies: Studies in the Child-life of India (1904), Shubala: A Cbild-mother (1920) express her sympathy for women and for the health of mothers and infants. Her writing already anticipated the problems of feminist politics:

The Pioneers of 1885 were impelled to service by their hearts: they talked little of 'Women's Rights': they were stirred to the core by women's needs. Feeling filtered through the heart. In 1935 feeling would seem to filter through the mind. Service is inspired and directed to a great extent by politics. Women's rights have become a slogan - rights visualized out of focus because of the belief that Western methods were to be closely imitated, and that the final achievement of English Feminists was to be our starting point. [...] So that whereas the Pioneers relied on study of local conditions or house-to-house contact with individuals, and on personal conviction as the only stable basis of Reform, the Leaders of today would seem to rely solely on Legislation and public agitation for the removal of social ills. (de Souza and Pereira 2002, XV)

Sarojini Naidu followed Toru Dutt's example and wrote poetry in English. In her three volumes of poetry, she celebrates women, traditional womanhood and the Indian countryside. Her poems have been criticised for their Anglo-Saxon romanticism and their lack of social concern. In spite of recent efforts to revive her poetry, she is remembered today primarily as prominent political activist in the national movement and as one of Gandhi's most important colleagues. Her career as a brilliant speaker and her creative use of English rhetoric have been documented in Speeches and Writings of Sarojini Naidu (1918), a selection of her lectures. Naidu's political activity promoted India's Independence and the modernisation of Indian society. Naidu's poetry is traditional in form and content. As an example, I include some lines from the often anthologised first poem "Palanquin - Bearers" of her 
poetry collection The Golden Threshold (1905). The anapaestic metre imitates the movement of the men carrying palanquins:

Lightly, lightly we bear her along,
She sways like a flower in the wind of our song;
She skims like a bird on the foam of a stream,
She floats like a laugh from the lips of a dream.

I have my doubts that palanquin-bearers were able to sing when they carried out their work. They remind me of the rickshaw-drivers in contemporary India and Bangladesh. Most of them are sweating heavily, gasping, coughing; sometimes they relax, when they find a short break for stretching their aching legs, backs, necks and arms. Sometimes - at least in Bangladesh - they even manage to smile, but they hardly ever sing. There is seldom social awareness in idealising poetry. In her use of the English language for poetry, however, Naidu was progressive. At the second All-India Writers Conference at Varanasi in 1948, she commented on the issue of an Indian literature in English: "Be masters of whatever language you like, so long as it is the language of the human heart and spirit. Literature is the only way truth can be kept alive" (Mehrotra 2003, 134). In India, English had become the medium of higher education in 1835. Although nationalists, conservatives and regionalists regarded English as the language of the colonial ruler and wanted a renaissance of pre-colonial languages, English remained with Hindi official and literary language after Independence in 1947. Since English is presently the language of only around four per cent of the population, the Indian poet writing in English still has to face the critique that she/he is writing for an international rather than a national audience. Another misconception is based on the assumption that poetry can only be expressed in the mother tongue, even though many contemporary Indian poets have been raised and educated in Englishspeaking families and regard English as their mother tongue. With the spread of mass communication, the English language adopted more and more Indian features from Hindi and regional languages. This Indian English describes modern Indian culture and society alongside traditions, local realities and ways of feeling. The poet Agha Shahid Ali points out that we have to distinguish between various forms of "Indian" culture, ethnic, history and religious background, and he depicts the particularities and the sensuality of Indian English:

I think we in the subcontinent have been granted a rather unique opportunity: to contribute to the English language in ways that the British, the Americans, and the Australians, also the Canadians, cannot. We can do things with the syntax that will bring the language alive in rich and strange ways, and though poetry should have led the way, it is a novelist, Salman Rushdie, who has shown the poets a way: he has, to quote an essay I read somewhere, chutnified English. And the confidence to

\footnotetext{
${ }^{6}$ Naidu, Sarojini. "The Palanquin - Bearers". An Illustrated History of Indian Literature in English. Ed.
} Arvind Krishna Mehrotra. Delhi: Permanent Black, 2003. 132. 
do this could only have come in the post-Independence generation. [...] What I am looking forward to - to borrow another metaphor from food - is the biryanization (I'm chutnifying) of English. Behind my work, I hope, readers can sometimes hear the music of Urdu. Of course, all this has to do with an emotional identification on my part with north Indian Muslim culture, which is steeped in Urdu. I, as I have grown older, have felt the need to identify myself as a north Indian Muslim (not in any sectarian sense but in a cultural sense). And I do not feel that this culture is necessarily the province of the Muslims; [...] many non-Muslim Indians can also consider themselves culturally Muslim. (Mehrotra 1992, 4)

Ali's tolerant and colourful model of the organisation of languages in multilingual societies must be kept in mind when we hear the claims of radical fundamentalists. Several contemporary Indian women poets are still deeply concerned with language issues and the impact of the mother tongue on women's role as transmitters and teachers of tradition and culture. Pre-independence poetry was hardly ever aware of the problems and tragedies of Indian life, but in the 1950s and 1960s, modern poets started writing about themselves, their experience and their awareness of others and provided Indian society with new insights (King 2004, 1).

Based on this introductory information, I want to show how contemporary Indian women poets portrait mothering and children in their poems. Facing the variety of attitudes and voices concerning this topic, it was difficult to make a choice. I decided on Kamala Das, Eunice de Souza, Melanie Silgardo, Sujata Bhatt and Imtiaz Dharker. These poets embody the variety of Indian society because they come from different religious, cultural and linguistic backgrounds. They represent two generations of the twentieth century Indian women and have influenced other writers and a broad audience. The five women poets will always first announce their particular concern of mothering.

\section{Kamala Das}

"Let us invade the brothels and rescue the children! The victims of rape are children!"

An Introduction

My Grandmother's House

Nani

Biography and Publications

"Kamala Das was awarded the Chimanlal Award for fearless journalism in 1986."

Kamala Das was born in Malabar/Kerala on March 31st, 1934 into a well off aristocratic Hindu family of the matrilineal Nair society. She was the only girl among her parents' five children. In her early infancy, she was mothered by her maternal grandmother because her mother spent more time writing poetry about mothering than practising it. Kamala Das was uprooted when her family went to 
Calcutta where her father was working. She was educated at home, attended a Catholic boarding school, and at the age of fifteen she was married to her mother's brother K. Madhava Das. In the matrilineal Nair society, girls are married to their maternal uncles in order to keep the property within the family. Das was sixteen when her first child was born. She has three sons. In her poetry and her autobiography, she describes the relationship to her husband as brutal and indulgent. Her husband developed a close friendship to another man. He supported her freedom and her writing, even when she was criticised for her sexually charged poetry and her unabashed autobiography. It is often the fate of confessional poets that the author is conflated with the poetic persona. In the 1970s, Das entered politics with a campaign for an indigenous green movement. She travelled throughout the countryside soliciting votes from the people in the villages. She failed to win a seat in Parliament, but she was awarded the Chimanlal Award for fearless journalism in 1986. She is currently the author of a syndicated column in India in which she writes against hypocrisy and corruption in private and public life and campaigns for women's issues and childcare. In 1999, Kamala Das converted to Islam and changed her name to Kamala Surayya. In several interviews, she has maintained that Islam and purdah provide women with security and protection.

Kamala Das has published several novels and short stories in her mother tongue Malayalam and in English under her pen name Madhavikutty. For poetry, she only uses English. Her collections of poetry include Summer in Calcutta (1965), The Descendants (1967), The Old Playhouse and Other Poems (1973), Tonight This Savage This Savage Rite: The Love Poetry of Kamala Das and Pritish Nandy (1979), Collected Poems (1984), Only the Soul Knows How To Sing (1996). Her autobiography My Story appeared in 1976. She was awarded several highly acclaimed prizes for literature and received an Honourary Doctorate by the World Academy of Arts and Culture, Taiwan, 1984.

Kamala Das and her Poetry

"Kamala Das's most remarkable achievement, however, is writing in an Indian English."

Kamala Das once said that she tried to imitate her mother Nalapat Balamani Amma (born 1909), who was a well-known poet writing traditional poetry in her mother tongue which was Kerala. Already at an early age, Kamala Das turned to writing poetry influenced by her maternal granduncle, the scholar-poet Nalapatt Narayana Menon. Balamani Amma translated a small collection of her poetry into English and wrote in her foreword: "My life that slowly unfolds its petals amidst the dazzling light is honeyed with poetry...I have tried my best throughout these poems to keep my optimism undimmed" (in Sanjuhta Das 1978, 196). Her daughter's poetry stands in sharp contrast to this sweet and sublime view. Kamala Das's 
first publication in the early 1960s caused a breakthrough for confessional poetry by women written in a seemingly colloquial English language. In Modern Indian Poetry in English (rev.ed. 2004), Bruce King stakes a large claim for Das's poetry:

Kamala Das's most remarkable achievement, however, is writing in an Indian English. Often her vocabulary, idioms, choice of verbs and some syntactical constructions are part of what has been termed the Indianization of English. This is an accomplishment. It is important in the development of a national literature that writers free themselves from the linguistic standards of their colonizers and create a literature based on local speech; and it is especially important for women writers. Such a development is not a matter of national pride or a linguistic equivalent of 'local colour'; rather it is a matter of voice, tone, idiom and rhythm, creating a style that accurately reflects what a writer feels or is trying to say instead of it being filtered through speech meant to reflect the assumptions and nuances of another society. $(2004,153)$

According to Eunice de Souza in Nine Indian Women Poets - An Anthology (1997), women writers owe a special debt to Kamala Das. "She mapped out the terrain for post-colonial women in social and linguistic terms" (8). Kamala Das writes about previously forbidden or ignored emotions, sexual needs within and outside marriage, suffering and shame caused by freedom and honesty. Other topics are the power politics in relationships, the instability of feelings, disappointment and depression caused by the division between body and soul, sexuality and love, and she often writes about death. Alongside these seemingly self-centred investigations, she expresses her sensibility for social injustice. Like her poetic foremother Sarojini Naidu, she moved from poetry to politics in the cause of social concerns.

Representation of Mothering and Children in her Poetry

In general, Kamala Das did not integrate her own motherhood and her children into her fiction and poetry. I found only one poem, "My Son's Teacher," about her four-year old son who witnessed the sudden death of his young woman teacher at school and could not understand it. A short story "Rice Pudding", which she wrote in Malayalam under her pen name Madhavikutty and translated into English, tells about the sudden death of a young mother and its impact on the life of her husband and her three small children (Tharu, Lalita, Volume II, 1993: 395397). In Kamala Das's life, the mother was almost absent. As a child, she watched her mother "write poetry lying on her bed all day long" (Tharu, Lalita, Volume II, 1993: 393). The maternal grandmother became the substitute mother who provided the familiar, secure, loving home. Das' memories return to the happy security of childhood at her grandmother's great house whenever she is depressed by her present insecurity. But she also remembers the lies which intrude into this idyllic time. Her poetry about prejudice, hypocrisy, social injustice, is an act of resistance, of maternal politics against silencing and oppression. 
Kamala Das, born 1934, was an adolescent when India gained Independence in 1947. Although Gandhi encouraged women to participate in the non-violent nationalist struggle, nationalism opposed social reforms for women and their participation in politics. Indian nationalists, who had received western education, accepted the western separation of the public as political and the private as apolitical realm. Women were confined to the private sphere and charged with the preservation of tradition. Women had to dress, talk and behave in a way that distinguished them from western women.

Normally mothers prepare their children for the difficult transition from childhood to adulthood. They help them to assume their role in society. Kamala Das was on her own in this period which she recalls in her poem "An Introduction." The title is open for several interpretations: "a formal personal presentation of one person to another or to a group or to the general public, the insertion of knowledge or experience, a preliminary part leading up to the main part" (Webster 2001, 428-429).

\section{Poems}

\section{An Introduction ${ }^{7}$}

I don't know politics but I know the names

Of those in power, and I can repeat them like

Days of week, or names of months, beginning with

Nehru. I am Indian, very brown, born in

Malabar, I speak three languages, write in

Two, dream in one. Don't write in English, they said,

English is not your mother-tongue. Why not leave

Me alone? critics, friends, visiting cousins,

Every one of you? Why not let me speak in

Any language I like? The language I speak

Becomes mine, its distorsions, its queernesses

All mine, mine alone. It is half English, half

Indian, funny perhaps, but it is honest,

It is human as I am human, don't

You see? It voices my joys, my longings, my

Hopes, and it is useful to me as cawing

Is to crows or roaring to the lions, it

Is human speech, the speech of the mind that is

Here and not there, a mind that sees and hears and

Is aware. Not the deaf, blind speech

Of trees in storm or of monsoon clouds or of rain or the

Incoherent mutterings of the blazing

Funeral pyre. I was child, and later they

\footnotetext{
7 Das, Kamala. "An Introduction". The Old Playhouse and Other Poems. Bombay: Orient Longman,
} 1973. 26-27. 
Told me I grew, for I became tall, my limbs

Swelled and one or two places sprouted hair. When

I asked for love, not knowing what else to ask

For, he drew a youth of sixteen into the

Bedroom and closed the door. He did not beat me

But my sad woman-body felt so beaten.

The weight of my breasts and womb crushed me. I shrank

pitifully. Then ...I wore a shirt and my

Brother's trousers, cut my hair short and ignored

My womanliness. Dress in sarees, be girl

Be wife, they said. Be embroiderer, be cook,

Be a quarreller with servants. Fit in. Oh,

Belong, cried the categorizers. Don't sit

On walls or peep in through our lace-draped windows.

Be Amy, or be Kamala. Or, better

Still, be Madhavikutty. It is time to

Choose a name, a role. Don't play pretending games.

Don't play at schizophrenia or be a

Nympho. Don't cry embarrassingly loud when

Jilted in love...I met a man, loved him. Call

Him not by any name, he is every man

Who wants a woman, just as I am every

Woman who seeks love. In him...The hungry haste

Of rivers, in me ...the oceans' tireless

Waiting. Who are you, I ask each and everyone,

The answer is, it is I. Anywhere and,

Everywhere, I see the one who calls himself

If in this world, he is tightly packed like the

Sword in its sheath. It is I who drink lonely

Drinks at twelve, midnight, in hotels of strange towns,

It is I who laugh, it is I who make love

And then, feel shame, it is I who lie dying

With a rattle in my throat. I am sinner,

I am saint. I am the beloved and the

Betrayed. I have no joys which are not yours, no

Aches which are not yours. I too call myself I.

My analysis would change the impersonal title "An Introduction" to "My Initiation into Modern Indian Society". A woman, who is also a poet, instructs her daughter how she developed her concept of identity against the cultural expectations of Indian womanhood. She knows that most children do not listen to their parents and are bored when talk takes too much time. Therefore she limits her narrative poem to 59 lines, in which she develops a whole series of identities and experience. The speaker of the poem introduces herself as a member of Indian society and enumerates the usual data, nationality: Indian, race: person of colour, "very brown", place of birth: "Malabar". Only the confession that she is ignorant 
of politics, but able to repeat the name of politicians like a child, hints ironically at her gender. In this respect, she meets the expectations of Indian society at the time of Independence. But then she opposes the claims of Indian nationalists for an Indian language. She asserts her freedom to express herself - and probably to dream as well - in an Indianised English which is alive in contrast to the "deaf, blind speech" of traditional images and metaphors taken from Indian nature and culture: "trees in storm", "monsoon clouds", "the incoherent muttering of the blazing / Funeral pyre". The poet defends her individual, "funny perhaps", "honest", "useful" speech as human and universal. From the development of her mind, she then turns to the changes of her body during puberty and pregnancy, for which she had not been prepared ("and later they told me"). She dares to mention secondary sex characteristics ("and one or two places sprouted hair"). She is helpless and pitiful confronted with her "woman-body" and "the weight of breasts and womb". Although her homosexual husband probably does not use physical violence ("he did not beat me"), she feels beaten by his infidelity. The poem's second part tells about resistance. The speaker of the poem lays claim to rights and freedom of men. She rebels against the imposition of feminine looks and docility. She adopts a male appearance or that of a westernised Indian woman ("I wore a shirt and my / Brothers trousers, cut my hair short"). She seeks sex and love outside marriage, but she cannot enjoy them without shame. In making her experience universal, she assumes her identity as a human individual ("he is every man who wants a woman, just as I am every / Woman who seeks love", "I too call myself I"). This introduction, this initiation speaks about the difficulties of growing up and prepares the way to adulthood.

I remember that Kamala Das has been called "a natural poet [... Always a hitor-miss poet, who wrote regularly but trusted the muse more than revision" (King 2004 , 147). Regarding the poem "An Introduction", a closer analysis of her poetical techniques contradicts this commentary. This long poem of fifty-nine lines of slightly irregular length presents itself as a monologue in front of an imagined audience. The colloquial language and run-on sentences create a natural speech rhythm, which is emphasised by the use of rhetorical questions and remembered imperatives. This form of a dialogue builds up a complex relationship between self and other. In the first part, the pronoun "I" stands against "they", "you", "everyone", "each". In the end, the "I" documents the found identity. Yet, the "I" does not only refer to the individual experience but to everyone who knows the universal human experience of frustration, pain and joy. Das' language achieves connections through assonance and alliteration: "critics, friends, visiting cousins." She uses internal rhymes for emphasis at crucial points: "Here and not there, a mind that sees and hears and / Is aware." "I am sinner, I am saint. I am the beloved and the / Betrayed." The poem consists of two main parts of equal length. The second part begins with "Then...", which can be read here as both adverb and conjunction. It introduces the time of a new beginning as the consequence of what has 
been said before. It is packed with remembered imperatives from her social environment, from "categorizers", which prescribe women's traditional roles in Indian society. The speaker of the poem rejects these instructions. She wears male clothes in daily life. In her poetry, she adopts male images and metaphor for herself. In Contemporary Indian Poetry in English (1990), Lakshmi Raghunandan points out that Kamala Das alters and inverts the traditional love theme when she writes that "he" is "the hungry haste / Of rivers' while 'she' is 'the oceans' tireless / Waiting" $(1990,68)$. The poet uses a traditionally male imagery to articulate an aspect of female sexuality and sexual desire. Kamala Das shows that a woman poet's conflict with poetic tradition is not only one of content, but there is a corresponding uneasiness with inherited imagery. Many western feminist poets have also expressed their discontent with poetic tradition and language. In Stealing the Language - The Emergence of Women's Poetry in America (1986), Alicia Suskin Ostriker points at women poets' appropriation of language already in the title. Radical feminist poets abandon male images, metaphor and myth. Kamala Das just occupies them. This is a more liberating act. A psychoanalytically minded critic might interpret this poem as an account of female psychic and sexual development. My approach includes the historical and regional context as well as a text-guided analysis with an inclination towards liberal humanism that reads the text as a transparently crafted poem containing all the meanings of an introduction mentioned above. On the one hand, it is a young woman's initiation into the Indian post-colonial society. On the other hand, it introduces the western reader into some aspects of the social situation and the poetic heritage of the Indian woman poet.

My Grandmother's House ${ }^{8}$

There is a house now far away where once

I received love.......That woman died,

The house withdrew into silence, snakes moved

Among books I was then too young

To read, and my blood turned cool like the moon

How often I think of going

There, to peer through blind eyes of windows or

Just listen to the frozen air,

Or in wild despair, pick an armful of

Darkness to bring it here to lie

Behind my bedroom door like a brooding

Dog........you cannot believe, darling.

Can you, that I lived in such a house and

Was proud, and loved.......I who have lost

\footnotetext{
${ }^{8}$ Das, Kamala. "My Grandmother's House". The Old Playhouse and Other Poems. Bombay: Orient
} Longman, 1973. 32. 
My way and beg now at strangers' doors to

Receive love, at least in small change?

This poem prepares the reading of the next poem and shall only briefly be analysed. It is a poem about the innocent love of childhood and the sexual desire and frustration of the present time. Beginning like a fairy tale, the poem's first sentence seems to celebrate domesticity and happiness; but it turns into an elegy of loss, decay and mourning. "A dead woman, a silent house with blind windows, snakes among the books" describe a perished world. Confronted with the nightmare of decay, the speaker is paralysed and driven to despair. The repetition of oand u-sounds creates a tune of wailing and mourning. The demonstrative pronouns and adjectives evoke the impression of a speaker staring into the darkness trying to overcome the gap between present and past. The poem leads the reader's imagination into a small place that is filled with meaning. In the next poem, this place is connected with death and social critique.

Nani ${ }^{9}$

Nani the pregnant maid hanged herself

In the privy one day. For three long hours

Until the police came, she was hanging there

A clumsy puppet, and when the wind blew

Turning her gently on the rope, it seemed

To us who were children then, that Nani

Was doing, to delight us, a comic

Dance.....The shrubs grew fast. Before the summer's end,

The yellow flowers had hugged the doorway

and the walls. The privy, so abandoned,

Became an altar then, a lonely shrine

For a goddess who was dead. Another

Year or two, and, I asked my grandmother

One day, don't you remember Nani, the dark

Plump one who bathed me near the well? Grandmother

Shifted the reading glasses on her nose

And stared at me. Nani, she asked, who is she?

With that question ended Nani. Each truth

Ends thus with a query. It is this designated

Deafness that turns mortality into

Immortality, the definite into

The soft indefinite. They are lucky

Who ask questions and move on before

The answers come, those wise ones who reside

In a blue silent zone, unscratched by doubts

For theirs is the clotted peace embedded

${ }^{9}$ Das, Kamala. "Nani”. The Old Playhouse and Other Poems. Bombay: Orient Longman, 1973. 40. 
In life, like music in the Koel's egg,

Like lust in the blood, or like the sap in a tree....

The speaker of the poem recalls the suicide of a pregnant servant in her grandmother's house and the silencing of this tragedy. The woman, who had been a doll for her seducer, remains a doll in her death. For the children who cannot understand the situation, she seems to be a puppet hanging on a rope. Then yellow flowers overgrow the place of the tragedy. It is customary to honour the dead with flowers at funerals, to associate mourning with flowers. Flowers grow on graves and preserve the memory of the dead which the adults deny: "I asked my grandmother / One day, don't you remember Nani...Nani, she asked, who is she?" Grandmother's question ends Nani's existence, but initiates wide-ranging meditations about truth. For this purpose, the language changes from statements to the rhetoric of a sermon. Beginning with the observation that the grandmother answered her question with a question, the speaker of the poem considers the relativity of truth. Truth is always relative and has to be questioned. But her grandmother's attitude has another background. The grandmother who pretends not to remember turns a fact (mortality) into a condition or quality (immortality), something precise and certain into something vague, comfortable and weak. The speaker of the poem does not generalise about the position of her grandmother. In spite of her anger and repulsion, she does not use statements or definitions but works with similes. Those who regard themselves as being in possession of the truth inhabit a peace similar to death. The images of the last lines depict the polarity of life and death. The negative "clotted peace" refers to coagulated blood at the end of life, but it is also compared to "music in the Koel's egg". In Indian mythology, the Koel or the cuckoo is the image of Krishna. The bird's call awakens nature as Krishna's flute arouses vitality. This bird always usurps the nests of other birds. The Koel's egg hints at music which must be detected. The same applies to "lust in the blood" and "sap of the tree" which promises life when it is revealed and used. The poem Nani becomes a powerful indictment against complacency, indifference and rigidity. The very practice of remembering is an act of resistance and suggests a rethinking of society itself. Kamala Das continues this work in her present column:

Let us invade the brothels and rescue the children!

Perverts are on the increase in my home state, Kerala. Newspapers are no longer squeamish about reporting indiscriminate rapes. The victims are invariably children. [...] Till recent times, we were not acquainted with crime. During feudal times I was a little child and could not connect the death of any poor girl of the locality with crime. The rich men threw them into wells when they became conspicuously pregnant. Morality in those days meant the effective concealment of crime. But those pillars of society spared little girls. [...] Child prostitution was not to be discussed. Seventy per cent of the inmates of Indian brothels are children below 15. It is still not time to discuss the problem. It was brave of the People's Council for So- 
cial Justice, UNICEF and the National Women's Commission to organise a seminar in Cochin to discuss the problem of child prostitution. There were more men than women in the auditorium. [...] At last week's seminar there were papers read, speeches made all with appropriate passion and fury. But is the child prostitute going to benefit from this verbiage? Would it not be wiser to invade the brothels in a strong group and rescue the children from their humiliating bondage? [...] Until recent times children were not taught the facts of life. At the time of marriage, thebride-to-be is not told what kind of a contract she would be entering into. She is not told about the duties of a wife. How does society expect her to be an exemplary wife? (Internet Source (1): http://www.rediff/com/style/1996/1011das.htm)

Kamala Das' poetry and journalism about the role of women in modern Indian society and about social injustice result in maternal politics, in criticism of male violence, but also in harsh critique of upper-class women's complicity with caste and class oppression and lack of solidarity between women.

Kamala Das' poem "Nani" and her column remind me of women in refugee camps in Africa who have been systematically gang-raped and infected with HIV. Many of them are now dying slow, painful deaths from AIDS. Their testimonies speak of the shame, stigma and pain. Many women are caring for children left orphaned by the genocide. These children will be left orphaned for a second time. Rape and HIV have become military tools and weapons in modern warfare. During my work in Darfur, some local colleagues discussed the issue of gender violence - this is the official term now. One young man maintained that rape is a tradition, not a crime in some regions. The answer is "No". It is an abominable crime and the contempt of the female body begins with the sexual abuse of children in brothels. Kamala Das states in her column that Indian newspapers now report about rape. In many other countries this is not possible. Victims or persons speaking for them are often accused of provocation or defamation. The roles of victim and perpetrator are reversed. In "Woman Skin Deep: Feminism and the Postcolonial Condition" (1992), the Pakistani feminist literary critic and activist Sara Suleri reports the experience of a fifteen-year-old woman in Pakistan who was raped by two men of her own family, forced to confession of fornication and sentenced to hundred lashes in public (768). Analysing Pakistani law, Suleri examines the lived experience of women whose bodies are directly afflicted with them. Suleri and Das both criticise that women are not informed about the customary laws that affect them in their daily life. Suleri connects this experience with the local socio-historical context of Pakistani laws and the global political situation:

It is not the terrors of Islam that have unleashed the Hudood Ordinances on Pakistan, but more probably the U.S. government's economic and ideological support of a military regime during that bloody but eminently forgotten decade marked by the 'liberation' of Afghanistan. $(1992,768)$ 
Thus, Kamala Das' poems and her column initiated a discussion about the dichotomy between the local and the global which is a main concern of transnational and global feminist theory and politics.

\section{Eunice de Souza $(* 1940)$}

"Suddenly I see how it's possible in Gethsemane to say: I am the one you seek. Let the rest go free."

Catholic Mother

Sweet Seventeen

For a Child, Not Clever

For Rita's Daughter, Just Born

Biography and Publications

"Don't Look for My Life in These Poems."

Eunice de Souza was born in Poona in 1940 to Roman Catholic parents of Goan origin. She grew up there. She was educated and studied in Bombay and in the United States and received her Ph.D. from the University of Bombay with a thesis on "The Critic in a Post-colonial Culture". She joined St. Xavier's College, Bombay in 1969 where she was Lecturer in English Literature and later Head of the Department of English. She is now retired. She has also been involved in theatre as an actress and as director. Information about Eunice de Souza's private life is scant. But on the occasion of her visit to Portugal in 2001 she gave an interview. (Internet Source (2) <http://www.arlindo-correia.com/1000501.html). The text is accompanied by a photograph and a collection of poems. The photograph presents a handsome woman in her sixties, dressed in a comfortable and colourful house-dress. She is standing in her kitchen with a cigarette in her hands. Her parrot is sitting on her head. Both are looking out of the window. Both are probably talking about their observations from the yard. Eunice de Souza, "acknowledged as one of the best Indian poets writing in English", knows how to put both the protagonists of her poems and her own person on the stage. In this interview, she tells that she lost her father when she was three years old. He had been working for the government. She still keeps and honours some texts he had written, which prove that he also wanted to become a writer. She had a difficult relationship with her severe mother. She is not married. Forced by the inquisition, her family converted from Hinduism to Catholicism and adopted the Portuguese name in the seventeenth century. The poems escorting this interview guide our reading of Eunice de Souza's apparently confessional poems. In the poem, "Autobiographical", the speaker admits that she attempted suicide once. Alongside this poem, we find the admonition "Don't Look for My Life in These Poems": "Poems can have 
order, sanity / aesthetic distance from debris. / All I've learnt from pain / I always knew, / but could not do."

Eunice de Souza has published the following collections of verse: Fix (1979), Women in Dutch Painting (1988), Ways of Belonging: New and Selected Poems (1990). She is represented in several recent anthologies of women's poetry. She is the only woman included in The Oxford India Anthology of Twelve Modern Indian Poets (1992). Probably as a reply to Arvind Krishna Mehrotra, editor of this anthology and poet himself, she edited Nine Indian Women Poets - An Anthology in 1997, in which she included women writers from Catholic, Parsi, Hindu and Muslim background. She has published four popular books for children. She writes extensively about Indian culture and literature. Her recent publications Women's Voices - Selections from Nineteenth and Early - Twentieth Century Indian Writing in English (2002) and Purdah An Anthology (2004) have been useful for my research. A fierce literary critic, she has been writing for leading newspapers.

\section{Eunice de Souza and her Poetry}

"Poems can have order, sanity / aesthetic distance from debris."

As already mentioned, Eunice de Souza is the only woman included in Arvind Krishna Mehrotra's anthology, because only she could meet the editor's high standards of poetic technique, a body of published works and a preference for imagist poetry. Her poems resemble snapshots. The words describe the scenes in detail. Persons and places are named. The conversation is quoted. Individuals speak their natural Indian English idiom. Most of the poems move through these related fragments and end with an unexpected twist. The poet dramatises but does not comment. The ironic and sometimes satiric perspective results from the juxtaposition of the fragments. The majority of her poems do not represent lyrical moments but fragmented everyday narratives. Eunice de Souza is writing in free verse and lines of different length. Rhythm, number of syllables per line, returning syllabic and grammatical patterns structure her poems. I could not find comments by Eunice de Souza on her own poetry. Critics mention the influence of American imagist poetry. It is, however, important to acknowledge also the influence of traditional Indian poetry and philosophy. In The Oxford Anthology of Modern Indian Poetry (1994), the editor Vinay Dharwadker shows how Indian poetry in English has been influenced by stylistic and ideological movements in other specific Indian languages alongside poetry from Europe and America. In Modern Indian Poetry in English (2004), Bruce King describes the poetics of the Indian poet Ramanujan which can be applied to Eunice de Souza's poetry:

The sophistication with which Ramanujan recreates and treats South Indian culture is also reflected in his techniques, which like his translations, often seem a modern recreation of the spirit and methods of Tamil and Kannada verse. The word play, puns, inner rhymes, rhetorical devices, ironies, distanced neutrality of tone, under- 
statement, compression and elliptical progression have similarities to his translations. This does not mean that Ramanujan is unaffected by his reading of Yeats, Eliot and other moderns (who have influenced him), but he is highly aware of the conventions, techniques and structures of Indian verse and these have been used and transformed in his English poetry. $(2004,116)$

\title{
Representation of Mothering and Children in her Poetry
}

Eunice de Souza's memories of Catholic Goan life in Poona deal with its repression, prejudices, ignorance, social injustice and women's place in marriage and family. She is unmarried and childless. Her poetry is feminist in its awareness of women's oppression within the patriarchal system represented by the Catholic Church and the husband. The poet expresses her solidarity with other women. Her poems about children show tenderness and care without any sentimentality.

Poems

\author{
Catholic Mother ${ }^{10}$ \\ Francis X D’Souza \\ father of the year. \\ Here he is top left \\ the one smiling. \\ By the grace of God he says \\ we've had seven children \\ (in seven years). \\ We're One Big Happy Family \\ God Always Provides \\ India will Suffer for \\ her Wicked Ways \\ (these Hindu buggers got no ethics). \\ Pillar of the Church \\ says the parish priest \\ Lovely Catholic Family \\ says Mother Superior \\ The pillar's wife \\ says nothing.
}

Already the contradiction between title and poem hints at the woman's situation. The poem, entitled "Catholic Mother", deals with the father who is accompanied by his silent and always pregnant wife and by his seven sullen children. The mother, supposedly the protagonist, is mentioned as the "pillar's wife" and appears silent in the end. The father's ponderous clichés are rendered in capital let-

\footnotetext{
${ }^{10}$ De Souza, Eunice. „Catholic Mother“. Nine Indian Women Poets - An Anthology. Ed. Eunice de Souza. Oxford: Oxford University Press, 2001. 39.
} 
ters and corroborated by the parish priest and the nun. He scorns Hindu persons in his individual Indian English voice. The irony lies in the juxtaposition of the father's speech and the real situation. As always, wit and irony control and enhance anger and sadness. Adrienne Rich wrote: "Patriarchal thought has limited female biology to its own narrow specifications" (1977: 39). This poem speaks about the results of patriarchal practice. The poem's words should stick in our minds. The Catholic Church, here represented by the parish priest and the Mother Superior, continues to deny women the control of their bodies and counteracts with its prescriptions and inhibitions family planning and prevention of sexual transmitted diseases. The next poem deals humorously with women's bodily functions and the missing sex enlightenment.

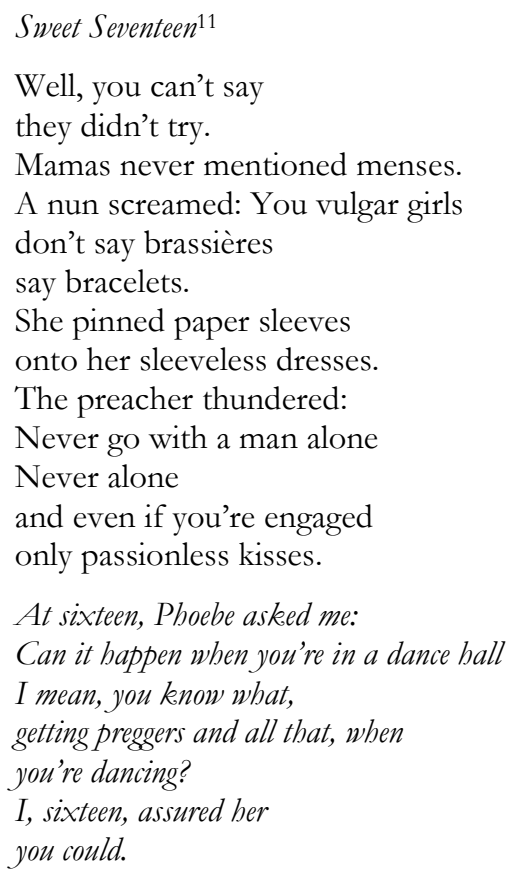

In The World Split open - Women Poets 1552-1950 (1974), the editor Louise Bernikow writes: "Men have written about 'women's art' with their noses wrinkled, as though it had a bad smell, like menstruation" (9). Eunice de Souza is not shy. "Mamas never mentioned menses", sounds like a slogan. The colloquial speech with its hesitations and repetitions "I mean, you know what" and the vernacular idiom "getting preggers and all that, when / you're dancing?" makes the blushing, the embarrassment and the fear really visible both linguistically and in a different typeface. It contrasts with the self-assured utterances of the speaker

${ }^{11}$ De Souza, Eunice. "Sweet Seventeen". The Oxford Indian Anthology of Twelve Modern Indian Poets. Ed. Arvind Krishna Mehrotra. Oxford. Oxford University Press, 1992. 116. 
"Well, you can't say / they didn't try", "I, sixteen, assured her / you could." This sounds almost like a male voice. Similar to Kamala Das in her poem "An Introduction", Eunice de Souza speaks about young women's ignorance of their own body and its functions. The short dialogue between Phoebe and Eunice, both sixteen, reveals their anxiety and underlines the irony of the title. How shall it be possible to enjoy the age of "sweet seventeen" surrounded and oppressed by prudery, hypocrisy and dissimulation? Looking back at her childhood, the speaker of the poem uses poignant irony and distances herself from any glorification of childhood. In both her next poems, Eunice de Souza paints likeable portraits of children.

For a Child, Not Clever ${ }^{2}$

Once you thought it good

you came fifty-sixth in class

out of fifty-six children.

But Mummy, you said,

fifty-six is bigger than one.

Voices crackle and break

around you. Why do you provoke

your sisters? Why do you never

tell us about your tests?

To me, the cousin who visits

sometimes, you say, as if

explaining things:

I'm not clever,

you see, that's why these things

keep happening.

You pierced me with your pain

dunce dunce double d

Suddenly I see

how it is possible in Gethsemane

to say: I am the one you seek.

Let the rest go free.

Eunice de Souza included this poem into her anthology of women's poetry. Mehrotra's collection does not contain it. Does the male scholar criticise the lack of neutrality and impersonality in this moving poem? The poem starts with and returns to a five-syllabic line. The four statements which tell the story are also rendered in five-syllabic lines: "Once you thought it good", "But Mummy, you said", "Suddenly I see", "Let the rest go free". The poem starts with a seemingly comical scene. The "child, not clever" turns the hierarchical thinking of competition at school upside down and is ridiculed. As often, wit enhances sadness. The child,

12 De Souza, Eunice. "For a Child, Not Clever". Nine Indian Women Poets - An Anthology. Ed. Eunice de Souza. Oxford: Oxford University Press, 2001. 40. 
lonely in his own family, can only talk and explain his humiliation to a visitor: "I'm not clever", which means "I'm culpable". The poem ends with the gospel allusion of Christ's sacrifice as lyric climax and resolution. The Christian sacrificial imagery is used to emphasise the sufferer's innocence and the observer's compassion and guilt. Eunice de Souza shows that empathy and comprehension are necessary to deal with all aspects of children's emotional and social world and their conflicts, especially those of handicapped children.

For Rita's Daughter, Just Born ${ }^{13}$
Luminous new leaf
May the sun rise gently
on your unfurling
in the courtyard always linger
the smell of earth after rain
the stone of these steps
stay cool and cold
gods in the niches
old brass on the wall
never the shrill cry of kites.

In this imagist poem, Eunice de Souza returns to the imagery of traditional Indian poetry. She addresses the new-born girl as 'luminous leaf'. In continuation, the speaker of the poem adds her wishes in a carefully structured sequence of five stanzas. The poem starts with a stanza of three lines and ends with one of a single line which surrounds three couplets. Most lines contain four to six syllables. The poem starts with a five-syllabic and ends with a seven-syllabic line which echoes and must be connected with the second seven-syllabic line in the centre of the poem. Now we can read the wishes: "May the sun rise gently / on your unfurling", "(may) in the courtyard always linger / the smell of earth after rain / never the shrill cry of kites", "(may) the stone of these steps / stay cool and cold". The leaf needs sun and rain for its unfurling. First, the poem describes the effects of sun and rain on the child's natural ("earth") and cultural ("stone of these steps") environment. "Gods in the niches / old brass on the wall", may be understood as allegories of protection in Christian and traditional Indian culture. In Eunice de Souza's poem, the imagery reflects the influence of nature and culture on human life with its promises and its danger.

Eunice de Souza's poems on mothers and children express the poet's solidarity with women and her maternal thinking for children's well-being and healthy development. She is a compassionate, though ironic critic of women's oppression in

${ }^{13}$ De Souza, Eunice. "For Rita's Daughter, Just Born". The Oxford Indian Anthology of Twelve Modern Indian Poets. Ed. Arvind Krishna Mehrotra. Oxford: Oxford University Press, 1992. 121. 
her Catholic Goan society and tenderly caring for children who are not her own. The small objects of her poems hide the emotions of anger, tenderness, pity, sadness and joy with firm understatement.

\section{Melanie Silgardo (*1956)}

"Do not tell the children ghost stories."

Child

Do Not Tell the Children

Biography and Publications

Like Eunice de Souza, who was her teacher at St. Xavier's College in Bombay, Melanie Silgardo has a Goan Catholic background. She received an M. A. in English Literature at the University of Bombay, where she already started writing poetry and worked for several magazines. Together with two male colleagues, she founded the publishing co-operative Newground in 1978, which became an important institution for the poetry scene in Bombay. She then studied at the London College of Printing and became a Commissioning Editor with Virago. After eighteen years in publishing, she went to teaching creative writing courses. She lives and works in London as a free-lance editor and teacher.

Melanie Silgardo published a collection of poems in Three Poets (1978) and Skies of Design (1985), which was awarded the Best First Book Commonwealth Prize, Asian Section. Her poems have been included in several anthologies of women's poetry.

Melanie Silgardo and her Poetry

"Yet, I can feel the hundred things / you'd like to say / choke / as if the alphabet had jagged ends / that fixed inside your throat."

Similar to her teacher Eunice de Souza, Melanie Silgardo is highly aware of visual craft, economy and understatement. But her poems use more images than dialogue. Most of her poems are longer than those of de Souza. They start with a statement or an observation which develops into a more linear and argumentatively constructed lyric. The main subject matter is the psychology of the self and its relationship to others. Observations, associations, emotions and revelations are expressed in sometimes surprising and disturbing images. 


\section{Representation of Mothering and Children in her Poetry}

In the following poems on mothers and children, the speaker moves through changing emotions of mother and child in difficult stages of a child's development.

Poems

\section{Child $^{14}$}

You hold the toy at me as if it were the last barrier. Your little Christmas elephant with its ears all pink.

You are shy and move away. So I must stay here for a bit like the proverbial mountain, wait till some last smile can measure your frown and replace it.

Your experience of three years has made you wise.

And though you know the sun must daily sink into the sea, you will not trust my adult face, my dangling arms.

I talk too fluently, and smile too often and too long.

But I've not come to stay.

Yet, I can feel the hundred things you'd like to say

choke as if the alphabets had jagged ends that fixed inside your throat.

Sometimes, your head on one side you venture, tentative, brother of the sparrow.

You won't be kissed.

I too was a child my dear, my heart as large as your fist.

${ }^{14}$ Silgardo, Melanie. "Child”. Nine Indian Women Poets - An Anthology. Ed. Eunice de Souza. Oxford: Oxford University Press, 2001. 30. 


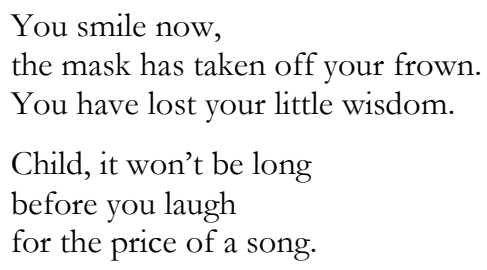

This poem expresses a mother's conscious reflections about her emotions when her three-year old child begins to distance himself from her. The poem consists of nine stanzas. The central fifth stanza contains an interruption in the word "choke". The stanzas leading to the bottle-neck have four to six lengthy lines, the stanzas following it only three, which are shorter. Visually and linguistically, the first four stanzas describe the mother's powerful position in relation to her small child. While she stands like "the proverbial mountain", the child protects himself and moves away. Humour and eloquence are used to overcome the painful situation of separation. She then realises his helplessness, he cannot defend himself with words. After this epiphany, she returns to childhood memories and identifies herself with the child. In the end, she will captivate him by a song. The last three stanzas already have the charm of a song with their end-rhymes "kissed", "fist"; "now", "frown"; "long", "song". Is it a conscious or a subconscious act that she again uses her power? It is probably both. On the one hand, it is certainly preferable to have one's throat cleared by a laugh than to have it choked by "jagged ended alphabets". On the other hand, the last stanza hints already at adult life where nothing is for free anymore, where one has to pay for everything, where even love and affection seem to have their price.

Do Not Tell the Children ${ }^{15}$

I cannot hold you in my hand for long nor comfort you with vagrant lullabies.

Your nature is to stray into the dark realms

of the hidden trees.

Comfort comes from knowing the safe places

deep and separate, past the beaches

and the furious sea.

You balance mountains on your forehead and pine trees on your finger tips.

Alone, you fight the night screeches

of the sleepless birds and build your defences

like the jackal in the silhouette

of the enormous hill.

15 Silgardo, Melanie. "Do Not Tell the Children". Nine Indian Women Poets - An Anthology. Ed. Eunice de Souza. Oxford: Oxford University Press, 2001. 33. 


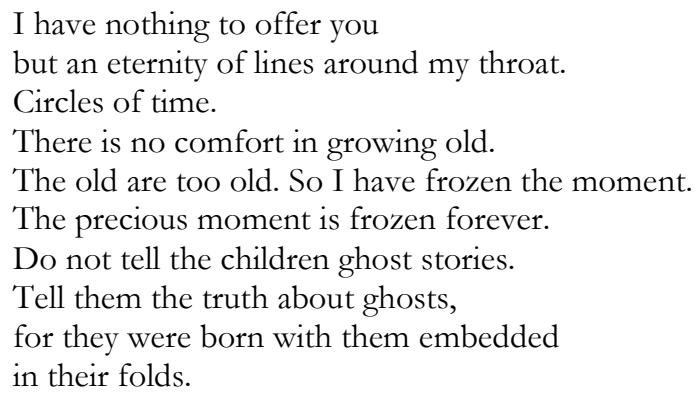

This poem confronts a child's state of mind with that of an old person. The poem consists of two long stanzas of almost the same length. The first stanza has thirteen, the second ten lines. The first stanza follows the path of a child into the exterior real world, then to knowledge and into the realms of fantasy and power. This is told in long and fluid sentences, the lines are rhythmic, the preferred metre is iambic. Sounds and half-rhymes link the lines. Repeated words and grammatical structures carefully connect thoughts. This speaker's regret that she cannot comfort "with vagrant lullabies" is linked to the statement that comfort "comes from knowing the safe place..." The whole adventure is described in images which occupy the senses and the mind. The child will "stray", "balance" and "fight". A confident and optimistic view on life and world predominates. The second stanza creates the point of view and state of mind of an old, "too old" person. Its structure parallels the first. Like the first stanza, it starts with a negation and regret: "I cannot hold you...", "I have nothing to offer you...".This is a pessimistic and frustrated state of mind: "There is no comfort in growing old." If "comfort comes from knowing the safe places deep and separate, past the beaches and the furious sea", the old speaker admits that she did not find them. The situation of the old person is described in short, isolated sentences. The repetition of words emphasises the static condition. The speaker decides to save the child from this development. She wants to preserve the precious moment described in the first stanza: the experience of freedom, safety, and personal power free from fear and anxiety. She does not want to haunt the child with stories about the dead who often represent traditional customs and beliefs. But the description of the present condition in the second stanza reveals the despair about ageing and lets the child know it. Thus, the poem demonstrates in its structure how difficult it is to find a balance between helpful and paralysing information about the past. I will briefly add a psychoanalytic reading of the poem. In other poems, Melanie Silgardo seems to be preoccupied with her difficult relation with her father. Her poem "For Father on the Shelf" contains these startling stanzas: "Father, you will be proud to know / you left something behind. / The year you died / I inherited a mind. // Wherever you are, will you / turn your index finger away? // And now I'm writing with my life. / The price of an inherited crutch." 
Living and working already for a long time in the British diaspora, Melanie Silgardo's poetry on mothering and children is more concerned with the general psychology of the relationship between mothers and children and with a child's psychic and imaginative development than with issues of Indian society. But her sensitive view on and dealing with the past makes her an important voice in postcolonial, multiethnic and multicultural societies.

\section{Sujata Bhatt (*1956)}

"Her mother's scalp cracked and bleeding until the doctor shaved off the waistlength thick grey hair and tightly bandaged the head."

Kalika

Biography and Publications

Sujata Bhatt was born in Ahmedabad, India in 1956. Her mother tongue is Gujarati. As a young girl, she went with her parents to the United States where she studied at the Iowa Writers Workshop. She started writing poetry in her late twenties. She is married to the German poet and artist Michael Augustin and lives in Bremen, Germany where she is working as a freelance writer and translating Gujarati poetry into English. Sujata Bhatt has published three books of poems: Brunizem (1988), which won the Commonwealth Poetry Prize for the Asia Section, Monkey Shadow (1991) and The Stinky Rose (1994).

Sujata Bhatt and her Poetry

Sujata Bhatt uses the continents where she has lived as her poetic landscape: her growing up in America, her Indian family background, her German marriage. She foregrounds her bilingualism and her multiculturalism. On the one hand, her use of the Gujarati language and script in some of her poems has been criticised as a sentimental and exotic treatment of India. On the other hand, critics value her mastery of the English language with its fluid free-verse lines and various rhythms. In contrast to other Indian women poets, she uses simple images that invest the physical world with significance.

Representation of Mothering and Children in her Poetry

Sujata Bhatt writes about women's sexual and maternal instincts and relations within the family. The portraits of her grandparents and her brother are often connected with suffering, illness and death. She has written poems about the position of women in society; but the question of gender is not central to her poetry. 
Poem

Kalikea $^{16}$

In the morning, while Kalika combs

her seven-year-old daughter's glossy tangled hair,

she looks at her face in the mirror;

red-eyed, worn out,

she feels she has grown into a mangy stranger overnight.

Her daughter's face: wide open eyes

so much more like her mother's

who died last night

in a diabetic coma.

As Kalika parts the hair in the centre, a straight line curving down

the back of her daughter's head;

she remembers, five years ago

blisters on the back of her mother's head

grew and grew, never healing,

her mother's scalp cracked and bleeding

until the doctor shaved off

the waist-length thick grey hair

and tightly bandaged the head.

As Kalika watches her daughter open the door

the sun falls on the bright red ribbons

flowering at the ends of the freshly made braids,

and there is her mother in a red sari,

walking towards the sound of temple bells.

Green herbs, white jasmine in her hands,

tiny red blossoms woven in her coiling hair.

Later, tearing out sticky cobwebs

from corners in the high ceiling,

while jabbing at fleeing spiders with a long-handled broom,

Kalika winces, glances out the window

and sees her daughter on the lawn

struggling with her doll's matted hair.

This poem tells about a woman who combs her daughter's hair and remembers the illness and death of her mother. She finds consolation and a new affirmative attitude towards life when she observes her daughter occupied with her doll's hair. The poem is firmly structured. It consists of four stanzas with six to ten lines written in fluid free verse and many linkages of sounds. Stanza two and three are linked together by the repeated "as" at the beginning. These two stanzas recollect the memory of the mother, while the first and the fourth stanza tell about the present

16 Bhatt, Sujata. "Kalika". Brunizem. Manchester: Carcanet Press Limited, 1988. 24. 
moment. In all stanzas, the poet moves from the object - an observation in the real world or her activity - to her subjective feelings or to memories. Her daughter's eyes, wide open, remind her of her dead mother and her own red-eyed face as the expression of her exhaustion and mourning. Combing her daughter's hair brings back the remembrance of her mother's shaved scalp during her illness. Her daughter's freshly plaited braids with their red ribbons recall the apparition of her mother as a bride. In the last stanza, the activity of "tearing out sticky cobwebs" and "jabbing at fleeing spiders" hints at the work connected with mourning and underlines the fact that ordinary life continues. The poem's social world is that of women caring for each other from mother to grandmother and child, from child to doll. It celebrates women's activity and community. This poem alludes in its title and with its emphasis on the close community of women to India.

For me, this poem has a particular meaning. In refugee camps and slums of the Third World, mothers often try to ornate and embellish their small daughters with nicely made braids and ribbons in their hair. These are the only means which are left. It is, however, often necessary to shave off the hair in order to treat skin diseases. In many case, the mothers continue to shave their children's heads because it is easier to cope with parasites, fungal infections and impetigo. Then the children are stigmatised by their bald heads and still more when they are treated with solutions that dye the scalp dark blue.

\section{Imtiaz Dharker (*1954)}

„Purdah is a kind of safety. / The body finds a place to hide.”

Outline

Purdah I

Purdah II (sections)

Choice

Zarina's Mother

Adam's Daughter

Living Space

Biography and Publications

"Imtiaz Dharker is one of the few women poets from a Muslim background."

Imtiaz Dharker was born in Lahore/Pakistan in 1954 and raised and educated in Scotland where she received a M.A. in English Literature and philosophy. She broke with her Pakistani family and married an Indian author from Hindu society. She has a daughter who is an actress. She lives in London and Bombay. She is also a documentary film-maker concerned with political and social injustice. One of 
her documentaries won the Silver Lotus Award for the best short film in 1980 . She is also a painter and accompanies her books with her own line drawings.

Imtiaz Dharker has published three books of poetry: Purdah in 1989, Postcards from god in 1994, I speak from the Devil in 2001.

Imtiaz Dharker and her Poetry

"As a film-maker and a painter, Dharker has an instinct for the dramatic structure and for imagery."

Imtiaz Dharker's poetry has been described by Bruce King as “consciously feminist, consciously political, consciously that of a multiple outsider, someone who knows her own mind rather than someone full of doubt and liberal ironies" (King $2004,321)$. The recurrent themes in her poems remain gender politics, geographical and cultural displacement, social injustice, political violence. In her first book Purdah, she still regards displacement as a trauma of exile and alienation. In her last book I speak from the devil, she celebrates, however, unsettlement as exhilarating settlement at the interstices.

Her books are conceived as sequences of poems and drawings. In each section, poems develop around a basic theme. As a film-maker and an artist, Dharker has an instinct for the dramatic structure and for imagery. She writes in free verse, which sounds rhythmic and often iambic. Similarities of sound, half-rhymes, assonance and alliteration connect the lines. In her two-part poem Outline, Imtiaz Dharker seems to describe her own poetics.

\section{Outline $^{17}$}

A solid figure struggles out of rock.

The sculptor's chisel

chose to stop

at just this moment, leaving

the body locked

in a great struggle, trembling

on the fine edge between

being trapped, and being free.

***

The artist tries, time after time, to trap the human body

in a fine outline;

and finds himself, instead, cut loose,

floating free through the spaces

of the wheeling mind.

Both parts deal with the conflict between artist and work of art. In the first part, the artist consciously stops when the work still hides its secrets. In the second

${ }^{17}$ Dharker, Imtiaz. "Outline”. Purdah and other poems. Oxford. Oxford University Press, 1989. 53. 
part, the artist, now driven by associations from her subconscious, continues to complete the work. The highly technical achievement of this poem describes the transition from tradition to freedom and self-assertion. The early parts of each stanza are firmly held in place by external and internal rhymes ("rock", "stop", "locked" // "time", "outline2), alliteration and assonance. They are set in opposition to the movement of the later parts. Whereas the first stanza only allows a hesitation, a "trembling", the second stanza gives permission to "floating free" and opens the mind. The opposition of tradition and freedom, matter and mind is crucial in many poems of Imtiaz Dharker. Especially in her political poetry, Dharker evokes this tension between artist and the work of art. Bruce King writes: "The poetry of commitment and politics is seldom as successful" (2004: 326). Dharker's colleague Eunice de Souza criticises: "The heart is certainly in the right place, but more than this is required for a poem to come alive" (1997, 49). The following reading concentrates on poems that come alive and wants to contradict King's and de Souza's judgement.

\section{Representation of Mothering and Children in her Poetry}

One can distinguish two groups of poems on mothering and children in Imtiaz Dharker's poetry. The first is concerned with the impact of Muslim culture on women's lives: the seclusion of women from public life, the use of shame in order to repress female sexuality, the resulting discrepancy between women's feelings and actions, especially in the situation of diaspora. Poems describe daughters rebelling against their mothers. There is, however, no condemnation of the mothers, but the recognition of the difficulties and the many ambiguities implied. The second group of poems is concerned with the poor and dispossessed mothers and children in Indian society.

\section{Poems}

Purdah $I^{18}$

One day they said

she was old enough to learn some shame.

She found it came quite naturally.

Purdah is a kind of safety.

The body finds a place to hide.

The cloth fans out against the skin

much like the earth that falls

on coffins after they put the dead men in.

People she has known

stand up, sit down as they have always done.

${ }^{18}$ Dharker, Imtiaz. "Purdah I". Purdah and other poems. Oxford: Oxford University Press, 1989. 14. 
But they make different angles

in the light, their eyes aslant, a little sly.

She half-remembers things

from someone else's life, perhaps from yours, or mine -

carefully carrying what we do not own:

between the thighs, a sense of $\sin$.

We sit still, letting the cloth grow

a little closer to our skin.

A light filters inward

through our bodies' walls.

Voices speak inside us,

echoing in the spaces we have just left.

She stands outside herself,

sometimes in all four corners of a room.

Wherever she goes, she is always

inching past herself,

as if she were a clod of earth,

and the roots as well, scratching for a hold

between the first and second rib.

Passing constantly out of her hands

into the corner of someone else's eyes...

while doors keep opening

inward and again inward.

Imtiaz Dharker understands purdah in its wider sense - not just the concealing garment of the burqua, but as control over women's lives. In the Muslim culture, the practice of purdah has its focus on the seclusion of girls who have reached puberty whether they are married or not. There is a number of publications on purdah and female education available which provide a range of attitudes to and experiences of purdah. In the last years, Kamala Das' conversion to Islam and her endorsement of the burqua launched its popularity in parts of India. This playful attitude is perhaps another form of subversion. Imtiaz Dharker does not regard purdah as a fashion.

The book Purdah has four sections: Purdah, The Haunted House, The Child Sings, Borderlines. The opening Purdah-section contains poems about Muslim culture. Islamic customs and rituals serve as setting or analogies. Purdah $I$, the poem about the use of the burqua is formally structured. It opens with a stanza of three lines and ends with a stanza of four lines which resumes what has been said in the five longer stanzas in between. Each stanza uses the burqua as metaphor for the way women experience themselves and their surroundings and then comments on this in an ironic, humorous, angry or sad manner. The juxtaposition of 
observations or statements and comparisons or comments builds up the tension and the protest. This is Imtiaz Dharker's indictment: Islamic culture uses shame not only in order to repress women's sexuality but also as a barrier against women's spiritual and emotional independence. It leads women to falseness, ambiguity, distrust and isolation. Purdah, seemingly 'a kind of safety', 'fans out against the skin much like the earth that falls on coffins' 'while doors keep opening inward and again inward.' These doors lead into prisons for victims whose only crime consists in being a woman. The burqua as part of purdah exercises pressure and dictatorial control over many aspects of women's lives and leads to an alienation from one's own self. In the Purdah II - section, Imtiaz Dharker elaborates how this "mental purdah" transcends the individual and exercises its fatal influence on the community. The experience of Muslim women in the diaspora of England is a paradigm of the "clash of cultures" where the ignorance and arrogance of different religious and ethnic groups meet each other and result in violence and terror. Here are some short excerpts:

Purdah $I I^{19}$

They have all been sold and bought, the girls I knew, unwilling virgins who had been taught, especially in this strangers' land, to bind their brightness tightly round, whatever they might wear, in the purdah of the mind.

They veiled their eyes with heavy lids.

They hid their breasts, but not the fullness of their lips.

The men you knew were in your history, striding proud with heavy feet across a fertile land.

A horde of dead men held up your head, above the mean temptations of those alien hands.

You answered to your race.

Night after virtuous night.

You performed for them.

They warmed your bed.

${ }^{19}$ Dharker, Imtiaz. "Purdah II". Purdah and other poems. Oxford: Oxford University Press, 1989. 16. 
A coin of comfort in the mosque

clatters down the years of loss.

$* * *$

You never met those men

with burnt-out eyes, blood

dripping from their beards.

You remember the sun

pouring out of Maulvi's hands.

It was to save the child

the lamb was sacrificed;

to save the man,

the sourge and stones. God was justice.

Justice could be dread.

But woman. Woman,

you have learnt

that when God comes

you hide your face.

There are so many of me.

I have met them, meet them every day, recognise their shadows on the streets.

I know their past and future

in the cautious way they place their feet.

I can see behind their veils,

and before they speak

I know their tongues, thick

with the burr of Birmingham

or Leeds.

In her poem "Purdah II", Imtiaz Dharker especially deals with the difficulties of Muslim women living in the diaspora in England. But the poem also addresses the urgent problems of immigration and integration in general. The poem criticises the arrogance and intolerance of the Muslim culture and the racism of the other side. The poem reveals the violent of patriarchal religions. The Muslim and the Christian religion of the Old Testament are founded on expiatory bloody sacrifices. "Justice" exerted in the name of these Gods "could be dread". In the Western world, there has always been the illusion that all problems could be solved by spreading the Western standard of living to the rest of the world and by providing immigrants with education, occupation and security. But confronted with international terrorism and internal violence, Western societies have to acknowledge that they have failed so far and that they are probably on the wrong track. The attacks on the World Trade Centre, the recent violence in French suburbs with the destruction of pre-schools and schools demonstrate the hatred against the symbols of Western capitalism and its means of integration. At present time, mindless caricatures have violated religious feelings and have resulted in violence against 
Western institutions in Muslim societies world-wide. Our societies in West and East are far away from mutual understanding, respect and tolerance. Imtiaz Dharker's poems describe the cultural background and the difficult and painful situation comparable to a prison "while doors keep opening inward and again inward" without opening a door outwards.

Imtiaz Dharker published her "Purdah"-poems in 1989. Since my work wants to establish a dialogue among scholars and students of western and Third World contexts, I want to include and discuss Sylvia Plath's poem "Purdah" that she wrote in 1962, one year before her suicide.

Purda $b^{20}$

Jade-

Stone of the side,

The agonized

Side of green Adam, I

Smile, cross-legged,

Enigmatical,

Shifting my clarities.

So valuable!

How the sun polishes this shoulder!

And should

The moon, my

Indefatigable cousin

Rise, with her cancerous pallors,

Dragging trees -

Little bushy polyps,

Little nets,

My visibilities hide.

I gleam like a mirror.

At this facet the bridegroom arrives

Lord of the mirrors!

It is himself he guides

In among these silk

Screens, these rustling appurtenances.

I breathe, and the mouth

Veil stirs its curtain

My eye

Veil is

20 Plath, Sylvia. "Purdah". The Norton Anthology of American Literature. Fifth Edition / Volume 2. Ed. Nina Baym. New York/London: W. W. Norton and Company, 1998. 2751-2753. 
A concatenation of rainbows.

I am his.

Even in his

Absence, I

Revolve in my

Sheath of impossibles,

Priceless and quiet

Among these parakeets, macaws!

$\mathrm{O}$ chatterers

Attendants of the eyelash!

I shall unloose

One feather, like the peacock.

Attendants of the lip!

I shall unloose

One note

Shattering

The chandelier

Of air that all day flies

Its christals

A million ignorants.

Attendants!

Attendants!

And at his next step

I shall unloose

I shall unloose -

From the small jewelled

Doll he guards like a heart -

The lioness,

The shriek in the bath,

The cloak of holes.

Sylvia Plath uses the purdah as a metaphor for the unbearable oppression of women's sexuality and spirituality. The speaker, a collective "I", denounces the hypocrisy of the purdah that pretends to protect women from public observation but rather exposes them to the curiosity of men. Suppressed sexuality leads to greediness and violence of women and men. The woman sits "cross-legged", she smiles "enigmatically", she "gleams like a mirror". Men burn from impatience of getting to know what is under "the cloak of holes". Veiled women call for this intruding attention. The term "attendants" appears four times. Two times it refers to attendants who are present, who peep at physical traits: the eyelash and the lips. Two times it sounds like a cry for help, calling for attendants who are absent 
among the "million ignorants", "these parakeets", "macaws" in this woman's domestic life. The lyric "I", who is capable of writing this stylistically brilliant poem - only mind the connotations and ambiguities of this sophisticated vocabulary ("appurtenance", "concatenation", "sheath of the impossible", "chandelier") - is treated like a "small jewelled doll" by her husband. In this poem, Sylvia Plath's focus is on the self and the relationship between women and men. On the one hand, I object to Plath's appropriation of the "purdah" as metaphor for the "strait-jacket" of the bourgeois institution of marriage against which white, middle-class women rebelled in the 1960s. Their situation could not be compared to the living conditions of women in Muslim or Hindu societies. On the other hand, I am not familiar enough with Plath's work to regard this poem as a sarcastic parody of the shrill voices that second wave feminists sometimes used in the 1960s. I will leave this point of view to further discussions. In many of her poems, Sylvia Plath excludes the larger world. In other poems, especially those on her children, Plath expresses her closeness, her responsibility and her anxiety for their wellbeing ("Morning Song", "Child"). These poems convey a similar impression of isolation. Mother and child seem to live in a cocoon.

Imtiaz Dharker also expresses her tenderness and love for children, but she sees mothers and children in their historical and social contexts. The next section "The Child Sings" of her poetry collection Purdab has poems about children, mothers and mothering. The long three-part poem Choice conjures up the danger of repeating fatal maternal attitudes.

Choice $^{21}$

I

I may raise my child in this man's house

or that man's love,

warm her on this one's smile, wean

her to that one's wit,

praise or blame at a chosen moment,

in a considered way, say

yes or no, true, false, tomorrow

not today...

Finally, who will she be

when the choices are made,

when the choosers are dead,

and of the men I love, the teeth are left

chattering with me underground?

Just the sum of me

and this or that other?

${ }^{21}$ Dharker, Imtiaz. "Choice". Purdah and other poems. Oxford: Oxford University Press, 1989. 49. 
Who can she be but, helplessly, herself?

II

Some day your head won't find my lap

so easily. Trust is a habit you'll soon break.

Once, stroking a kitten's head

through a haze of fur, I was afraid

of my own hand big and strong and quivering

with the urge to crush.

Here, in the neck's strong curve, the cradling arm,

love leers close to violence.

Your head too fragile, child, under a mist of hair.

Home is this space in my lap, till the body reforms, tissues stretch, flesh turns firm.

Your kitten-bones will harden, grow away from me, till you and I are sure we are both safe.

III

I spent years hiding from your face, the weight of your arms, warmth of your breath. Through feverish nights, dreaming of you, the watchdogs of virtue and obedience crouched on my chest. 'Shake them off,' I told myself, and did. Wallowed in small perversities, celebrated as they came of age, matured to sins.

I call this freedom now, watch the word cavort luxuriously, strut my independence across whole continents of sheets.

But turning from the grasp of arms, the rasp of breath, to look through darkened windows at the night, Mother, I find you staring back at me.

When did my body agree to wear your face?

The first part of this poem deals with the rebellion of a woman who tries to escape with her own child her mother's fate. The second part reveals the close connection of love and destruction, protection and inhibition in the relation between mother and child. The third part seems to describe the present state of freedom, but ends with a haunting remembrance of the own mother. In her poem "Choice", Imtiaz Dharker applies the poetic tools she described in her poem "Outline". 
The first stanza describes the time of rebellion as time of choices and possibilities in long sentences, roaming around without coming to a decision or ending in a question. The second stanza has lost the vagueness of the first. It consists of descriptions and commentaries on the situation. The child is compared to a helpless kitten. The mother realises her power over her child and the resulting danger and thread. The third part describes the nightmares of guilt and shame following the rebellion. Even after an act of liberation ("Shake them off, I told myself, and I did.") the oppression remains the same. The second stanza echoes with "the grasp of arms, the rasp of breath" the situation of the first, "the weight of your arms, the warmth of your breath". Both stanzas of the third part begin with the pronoun "I" which seems to underline the found self-assertion and independence. But in the end, mother and I appear in close connection. The sentence, "Mother, I find you staring back at me", highlights the failed separation linguistically and visually. In chapter II of this study (on difference concerning race), we already encountered the concept of choice with its promises and the insight that choice is wrecked on the material reality (p. 18). The poem "Choice" develops the possibilities and impossibilities of choice on the psychic level. Imtiaz Dharker's poems describe the difficult task of women and mothers in multiethnic communities of the diaspora. Traditional values and customs must be subverted, cultural norms must be re-invented in order to build up a tolerant society against the hostility of both sides. This is a painful and precarious path. The poet does not give an answer. Her poem "Choice" ends with a question. But Imtiaz Dharker is conscious of the fact that in the Indian society many mothers and children will never have the possibility and the luxury of choice because they face and have to cope with life-threatening difficulties.

\section{Zarina's Mother22}

It's not that Zarina's mother is callous more that she is preoccupied.

There are so many things to do.

Just living is hard enough, when you

have four children, a drunken husband, and a clawing

hunger tearing you inside.

'Yes, I know what it is she's got.

The doctor told me. Not tomorrow, not next week, but one day

ten years from now

the disease will flare inside her.'

22 Dharker, Imtiaz. "Zarina's Mother". Purdah and other poems. Oxford. Oxford University Press, 1989. 42. 


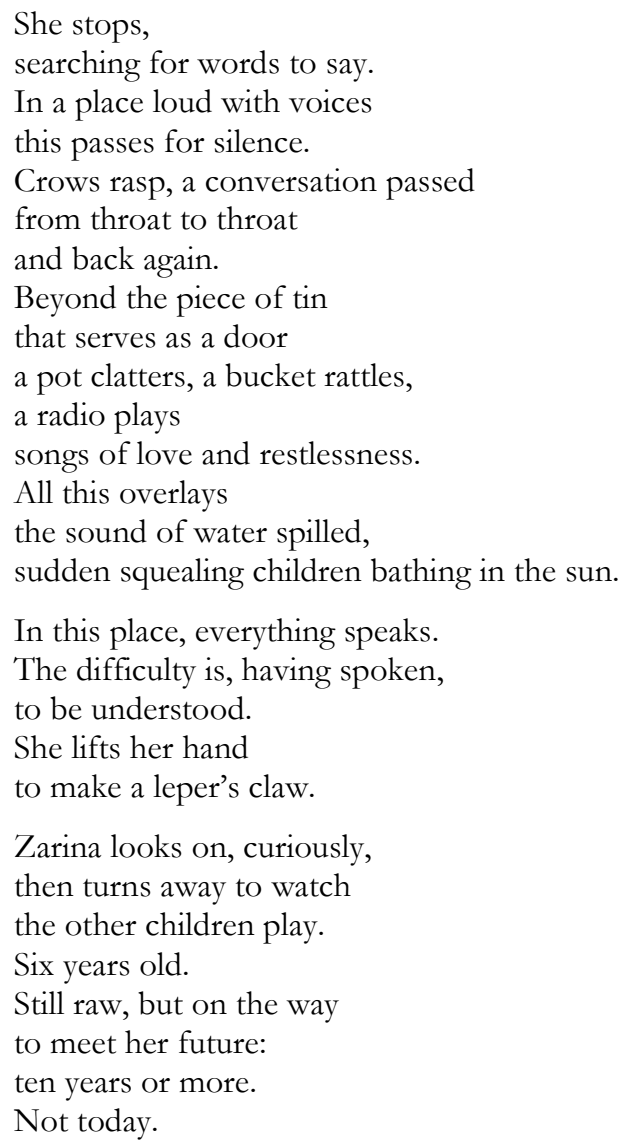

In this powerful poem, the speaker becomes aware of the gap between her own experience and that of a mother living in a slum. The speaker, who is in the beginning a distantly engaged onlooker on the misery of poverty, moves through guilt and pity to the identification with the other mother. The poem's first sentence corrects the prejudice of having judged as numbness a mother's stoicism towards the fatal illness of her daughter. Zarina's mother's taciturnity is juxtaposed to the noise of her surrounding: "a pot clatters", "a bucket rattles", "a radio plays songs of love and restlessness" (and there is no place to escape from this music), "crows rasp, a conversation passed from throat to throat and back again". "In this place everything speaks." "She lifts her hands to make a leper's claw": body language communicates what words cannot say. Is Zarina's mother preoccupied with having her disease, leprosy, transmitted to her child? Due to the long incubation period, the first symptoms could occur within some years. But probably Zarina is already ill. She does not play with the other children. She is only an onlooker. Her mother's apparent callousness is a defence against collapse. This mother struggles daily for survival. In the end, the speaker adopts Zarina's 
mother's taciturnity: “Ten years or more. Not today." In this poem, pity and pain impressively appear, because the speaker denies herself the overt expression.

From my own experience, I add to this "conversation passed from throat to throat and back again" the never ending cough at night, the wheezing and spitting of ricksha-drivers and daily labourers suffering from asthma and tuberculosis due to the ramshackle living conditions and the pollution. This poem speaks against preconceptions and generalisations of mothering. It conjures up memories of my work. There is the mother in India who keeps one of her many children at the edge of starvation because a severely malnourished child rouses more pity and is more effective as a beggar. The small girl - usually girls are sacrificed - earns the alms that help her family to survive. Another mother in Africa does not apply the medication to her seriously ill daughter according to my prescription and instruction. A detailed investigation reveals that her extended family - mother-in-law, old aunts and uncles - are against the survival of a handicapped child and put her under pressure. These mothers seldom admit that the child is starving. Usually, they say, "The child does not want to eat", "the child does not want to live". But mostly this child will immediately grasp at a biscuit that we offer. Imtiaz Dharker uses the comparison between a hungry child and a bird in her next poem. She is painfully right. But the mothers cannot be blamed for this. In a case of extreme shortage, the mother sets priorities. The apparent indifference of some very poor mothers towards the lives and deaths of some of their children grows out of a situation for which they are not responsible. The indifference of State and Church towards social and economic injustice must be blamed. I am not entitled to pronounce the judgement of "callousness" or even "unnatural mother" on these women without taking into consideration the horror of extreme poverty. I cannot force my emotions as "natural" or "normal" on a mother who is subjugated by hunger and dependency. Judgement must be accompanied by actions to change.

The poem "Zarina's Mother" reminds me of the article "Thinking about Mothers" (1990) by Janet Montefiore. It is a review of three books. Alongside a work of literary criticism and a psychological study of mother/child dynamics, she writes about "Death without Weeping: The Violence of Everyday Life in Brazil" (1992) by Nancy Scheper-Hughes. This is a long-term anthropological study of poor women in a sugar-processing city in the north-east of Brazil. These women expect to rear a statistical average of 3.4 children out of fifteen or sixteen pregnancies. Most of their babies die of malnutrition and related diseases in their first year of life. Since breast-feeding is incompatible with wage labour, the mothers are forced to feed their children with powdered milk and starch fillers dissolved in polluted water which starts the vicious circle of diarrhoea and dehydration. Janet Montefiore admits:

Scheper-Hughes's book makes the liberal or socialist feminism of English writers, including myself, appear steeped in the unconscious assumptions of privilege. It has therefore interrogated my own beliefs and practices as an English socialist 
feminist, and my own notion of what it means to be a mother, in a way no other book has ever done. [...] And I do not think that even non-essentialist feminists can be exempt from these strictures if they concern themselves only with the lives and writings of their own culture. (1990, 3003-3004)

Imtiaz Dharker's poem “Zarina's Mother” challenges our assumptions of mothering in a similar way and has similar resonance. The next three protest poems against social injustice appeared in Imtiaz Dharker's second collection of poetry Postcards from god (1994). The ironic title assumes that god is a visitor looking at a world and its inhabitants with disapproval: "What was I thinking of when I made this?" (79). The book has three sections: Postcards from god, Naming the Angels, Bombay: The Name of God. In three poems from the "Naming the Angels"section, Imtiaz Dharker works like a documentary filmmaker concerned with the social injustice of poverty. At the same time, she is highly aware of the disturbance caused by this work. Two poems that document the lives of poor children are set in contrast to a poem about a visiting photojournalist. The titles Namesake, Adam's Daughter and Adam from New Zealand underline the fact that poor people do not have a future. Generation after generation will remain in the slum. The child in the slum accidentally bears the same name as the visitor. But this is the only similarity.

Adam's Daughter23

Her eye is watchful, twisted

bird-like at me, her mouth

busy at the bread, teeth frantic at the crust

as small animals

worrying the dread.

At three years old

she has seen enough

to live in dread.

Hands give and often take away.

There is no pattern to it.

The food is there and sometimes

disappears. Her mother's hands

are often kind and suddenly rough,

knowing that the scraps she brings

will never be enough.

And women come

with heavy shoes where feet should be,

stirring up dust

as crows do, dangerously.

${ }^{23}$ Dharker, Imtiaz. “Adam's Daughter”. Postcards from god. Newcastle upon Tyne: Bloodaxe Ltd., 1997. 130. 
The street worms in upon us, rubs against her spine.

Her mouth works busily, but her mind is still, waiting to see what my next move would be. Out of her eyes, I see myself, crow black, vast, blocking out the sun.

This poem works best when it is read as a film sequence about the relation of a small poor child and a woman in duties of charity. The camera moves in and holds a long close-up of the child's face. While the child's "mind is still" and "her mouth works busily", flash-backs foreground incidents of the child's life: presence and lack of food, her mother's tenderness and harshness, bare-footed women and those with disturbingly heavy shoes. The spectator observes growing distrust in the child's face. Now the camera focus on the speaker's face and reveals her uneasy feeling and her awareness that her well-minded intention is also an intrusion, which is both needed and aggressive. In the poem Adam from New Zealand, the speaker aims at protecting women and children against the curious cameras of visitors:

"Adam is a journalist, / newly arrived in India / at twenty-six, eager to seek/ and understand, / and to record it all first-hand. / So on his way into Bombay / he has decided he must see / the real India in Dharavi. / / How can I serve up Zarina / or her brother Adam / to their random cameras? / they will smile shyly. / The aperture will open / to swallow up their souls. // Their mother will send out for Thums Up, or / from the stall at the corner of the lane, / glasses of hot, sweet tea. / She will put on a brave face, / but everyone in Dharavi will know / the world has come with cameras / to make a side-show / of her poverty. // Adam, your namesake lives in Dharavi. / But I will keep him out of reach / of your greedy camera. / He is too precious for you to see."

The last two poems protest against sensational and merely rational dealing with suffering in the world. This attitude depersonalises misery. Adam, the journalist from New Zealand, comes "to make a side-show of her poverty", but he remains oblivious of the human being affected. Does the last stanza sarcastically hint at the photos that show children fraternising with charity workers or soldiers always with their thumbs up? Mothering means protection in many different ways. One of them is the defence of dignity and intimacy. The next poem celebrates another power of mothering. 
Living Space ${ }^{24}$

There are just not enough

straight lines. That

is the problem.

Nothing is flat

or parallel. Beams

balance crookedly on supports

thrust off the vertical.

Nails clutch at open seams.

The whole structure leans dangerously

towards the miraculous.

Into this rough frame,

someone has squeezed

a living space

and even dared to place

these eggs in a wire basket,

while fragile curves of white

hung out over the dark edge

of a slanted universe,

gathering the light

into themselves,

as if they were

the bright, thin walls of faith.

This poem accompanies a carefully etched drawing and uses a similar sharp-lined technique in its first part which consists of short descriptive sentences. In contrast, the second part reflects the precarious condition of "these eggs in a wire basket" with its long undulating composition of sentences. It celebrates the courage to place an urgently needed article of food as an ornament in spite of the danger of this exposition. Eunice de Souza writes about this poem: "The strongest poem in the book, however, is 'Living Space', which catches exactly the ramshackle quality of life in this country, and the spirit of survival that so often and so mysteriously accompanies it" $(1997,49)$. Audre Lorde once described mothering as the "ability to make something out of anything" (1984: 174). This poem has the same message.

In Imtiaz Dharker's poems, the speaker remains the observing foreigner for all conditions of human life. The poet is more preoccupied with persons and their stories than with the temptations of playing with language. The poet registers the details as she saw them. She does not hide her emotions behind irony or sarcasm as Eunice de Souza does in her poem "Feeding the poor at Christmas". Sympathy and pity are expressed with admirable sensitivity and intuition without sentimen-

${ }^{24}$ Dharker, Imtiaz. "Living Space”. Postcards from god. Newcastle upon Tyne: Bloodaxe Ltd., 1997. 109. 
tality. Her voice is different from that of Eunice de Souza but equally skilled and crafted. I do not agree with Eunice de Souza's and Bruce King's criticism of Imtiaz Dharker's political poetry.

Imtiaz Dharker's consciously feminist and consciously political poetry indicts Muslim religion and culture for exercising control over women's bodies and minds and for alienating them from their own self. Her poems accuse the Islamic tradition of arrogance which leads to isolation from and hostility towards other social groups. Especially in the diaspora, this vicious circle creates violence and terror and makes escape extremely difficult. Under these circumstances, there will be no communication between cultures, neither in the form of hybridity nor nomadism. Imtiaz Dharker's starts basically with a call for mutual respect. Concerned with social injustice, Imtiaz Dharker develops a subtle and sensitive awareness of the learning process required to understand the different experience of poor women. Her art is engaged, but she remains sceptical about changes.

This chapter aimed at representing the wide range of themes and styles covered by the poetry of five Indian women poets writing about mothers and children. Although these women write from different religious, social and cultural backgrounds and not all of them regard themselves as consciously feminist, many of their poems explore the complexity of maternal feeling and thinking and put it on a political agenda. In particular, the poems indicate women's oppression in Catholic and Muslim society. There is a common concern about the confining, often haunting impact of tradition and religion on the development of the self and the society. These poems point at the failure of not introducing girls into society and of not preparing them for their roles as mothers and wives. They denounce sexual violence against girls and women because their writing reminds us of the victim's fate. In other poems, the emphasis shifts from the external world to the psychology of the self and of relationships, especially between mothers and children. There are poems about failure, about the pain that follows rebellion and the disappointment of freedom. In poetry concerned with social injustice of poverty, these sensitive psychological insights avoid any generalisation of their own maternal experience. I compared the egotism of the collective "I" in Sylvia Plath's poem "Purdah" with the social and historical concern in Imtiaz Dharker's poems. Additionally, I accompanied Imtiaz Dharker's socially critical poems with examples from my work as physician and with Janet Montefiore's article "Thinking of Mothers." Both question the adequacy of a general concept of mothering.

At the end of this chapter, it is possible to sum up how these five Indian women poets writing in English deal with the difference of gender, race and ethnicity on mothering. Most poems expose gender and ethnicity as interlocking oppressions. Racial difference is not treated as an important factor in a predominantly white society. This contradicts my impression that "shadism" - the whiteness of the skin - still plays a decisive role on the Indian marriage market. Socially aware poetry indicts the devastating impact of class oppression on mothering. 
Reference to the "different materiality" of life had already questioned the celebration of difference in the theoretical part. This can be understood as a noble paraphrase of class difference. Consideration of class seems to be out of fashion in feminist theory. Indian women's poetry introduces, however, the impact of class difference on mothering as a salient feature. These poems advocate reforms of education and political actions to improve the economic and social situation for mothers and children.

Art, even about victims, often ends in victories and affirmation. But these five sceptical women poets do not offer easy solutions. Poetry transcends reality and lived experience. It uses words to create beauty. The close analysis of particular poems revealed how form and content are interlocking and depend on each other. These poems are different in form, styles and tones: witty, ironic, economic, flamboyant. They are working with imagery, narrative, dialogue and scenic elements. We have learned that they blend stylistic and ideological Indian tradition with poetry from Europe and America. The conventions of poetry seem to coincide in many cultures. This coincidence invests poetry with the role of a go-between.

During my research, I felt increasingly uneasy about the one-sidedness of my approach. Mothering, understood as caretaking and a protecting capacity and activity towards another person, cannot be claimed for women alone. Having reached almost the centre of my study, I allow myself a digression and include a poem about a father written by the Indian poet Dilip Chitre (born 1938).

\section{Father Returning Home ${ }^{25}$}

My father travels on the late evening train

Standing among silent commuters in the yellow light

Suburbs slide past his unseeing eyes

His shirt and pants are soggy and his black raincoat

Stained with mud and his bag stuffed with books

Is falling apart. His eyes dimmed by age

Fade homewards through the humid monsoon night.

Now I can see him getting off the train

Like a word dropped from a long sentence.

He hurries across the length of the grey platform,

Crosses the railway line, enters the lane,

His chappals are sticky with mud, but he hurries onward

Home again, I see him drinking weak tea,

Eating a stale chapati, reading a book.

He goes into the toilet to contemplate

Man's estrangement from a man-made world.

Coming out he trembles at the sink,

The cold water running over his brown hands,

${ }^{25}$ Chitre, Dilip. "Father Returning Home". The Oxford Anthology of Twelve Modern Indian Poets. Ed. Arvind Krishna Mehrotra. Oxford: Oxford University Press, 1992. 112. 
A few droplets cling to the greying hairs on his wrists.

His sullen children have often refused to share

Jokes and secrets with him. He will now go to sleep

Listening to the static on the radio, dreaming

Of his ancestors and grandchildren, thinking

Of nomads entering a subcontinent through a narrow pass.

Not only mothers are exhausted from daily struggle. Fathers, as breadwinners and "nurturers" of their families, are worn-out from busy urban work and life as well. The analysis of this poem and the whole issue remains for another study which must correct the slant perspective. This study continues with poetry on mothering by Caribbean women poets. 


\section{English Poetry by Women from the Caribbean and the Diaspora: Una Marson - Louise Bennett - Olive Senior - Lorna Goodison - Jean 'Binta' Breeze}

At the end of his contribution to Christa Jansohn's Companion to the New Literatures in English (2002), Gordon Collier, the author of the essay on "The West Indies," confesses his omissions:

I have omitted drama, theatre and performance poetry from this survey.[...] Likewise part of the literary scene [...] are those perennial outgrowths of the slave past, Carnival and calypso, which represent one of the world's supreme expressions of sophisticated artistic folk collectivism. Further down the line, there is a gamut of textual and musical forms [...] involved in reggae and dub poetry. To list all these phenomena like this is to risk calumny rather than commendation, and the same applies to another equally unguarded lumping-together at the end of what looks like a highly masculinist assortment of masters of the master-tongue. I am referring, of course, to women writers, who have so far been enlisted as though they enjoy mere pendant status, If this were once the case [...], it certainly is no longer so. [...] Women writers of British West Indies origin occupy an ever-enlarging window of creativity - indeed, by now a majoritarian one - that has begun to open since the late 1970s. (129-130)

Yes, women are left out in his essay which interprets the texts of four men: George Lamming, Wilson Harris, Derek Walcott and Edward Kamau Brathwaite. But Collier connects his homage to British West Indian women writers with a plausible justification for his omission:

The developmental time-frame which I have set up here centres on the peak of literary activity forming in the 1950s and 1960s. It happens to be male writers who have been singled out in terms of the 'critical density' of their literary production; women writers simply did not feature at that developmental stage. (130) 
If this were true in the 1950s and 1960s, it is no longer the case. Since this time, women writers from the English-speaking Caribbean have gained international reputation within the academy. Their works have been included in anthologies of British writing and have found critical assessment. Women poets of Caribbean origin living in the diaspora in Britain have contributed to the development of performance and dub poetry and have gained an increasingly high media profile, for example, Grace Nichols and Jean 'Binta' Breeze.

The 1950s and 1960s also indicate the shift from the colonial term "West Indies" to the notion of the "Caribbean" which designates the postcolonial situation. Collier mentions the "perennial outgrowths of the slave past". The history of the West Indies is overshadowed by the Atlantic slave trade, the "Middle Passage". The need to find workers for the plantation work in the new colonies, led to the deportation of about 12 million Africans for more than 300 years. Many of them died due to the inhumane conditions on the ships. Those who survived usually landed first in the Caribbean to work on sugar, tobacco and cotton plantations. In 1807, slave trade was abolished and slavery thirty years later. Then slaves were replaced by Asian contract workers. Neither Africans nor Asians came voluntarily to the West Indies. They were forced by slave hunters or by poverty. In the process of decolonisation, Jamaica achieved self-government in 1944, Trinidad and Tobago in 1962. Independence from colonial rule almost always opened the door for North American industrialisation. The influence of strong economies of the First World often changed the situation of the urban poor black and the rural population for the worse. Caribbean life consists of a complex interaction of different cultures and lifestyles. Caribbean literature is a confluence of various ethnic literatures, primarily African, enriched through Indian, Asian, Chinese and other influences. Caribbean women writers explore the history of their country, the legacy of slavery and women's place and women's culture within these complex intersections.

In Making Men - Gender, Literary Autbority, and Women's Writing in Caribbean Narrative (1999), Belinda Edmondson argues that African American feminist theory and writing have provided the theoretical framework for the Caribbean femaleauthored texts. In the preceding chapters on difference concerning gender and race, I already described these aspects that Edmondson summarises concisely:

I submit that the project of a black feminist aesthetics inheres in its apparent paradox: to re-engender black women as women, not as monstrous matriarchs but as 'natural' women, within the black community; and to racialize black women within the feminist community and therefore to establish difference and a separate category of essence. (Edmondson 1999, 100)

In Out of the Kumbla, Caribbean Women and Literature - an anthology of Caribbean feminist literature and criticism (1990), Carole Boyce Davies and Elaine Savory Fido approve of Alice Walker's redefinition of feminism as "womanist", arguing that the term has "strong Caribbean roots" (XII). Both authors are insiders and outsiders of the 
Caribbean. Davies is Caribbean by birth and spent her childhood and some adult years in the region. Fido came in her twenties and essentially "grew up" (XV) in the Caribbean. She maintains:

In the Caribbean, we tend to see a gentler version of political action on the part of women [...]. Womanism is for me a softer, more flexible option than feminism. Feminism is necessary as protection, as groundbreaking work, as our best route to a new landscape of gender relations. [...] I see the need for drawing men and the condition of men into the discussion of Caribbean women's experience. (XV)

In their discussion of feminism/womanism, the authors deal with the political agenda and the cultural manifestation of feminism and avoid an either-or dualism. Their poems demand both a close reading and a close listening because the use and practice of language is central to the Caribbean experience. The African slaves were deprived of their language. In her poem "Discourse on the Logic of Language", the poet Marlene Nourbese Philip cites Edict I: Every owner of slaves shall, wherever possible, ensure that his slaves belong to as many ethno-linguistic groups as possible. If they cannot speak to each other, they cannot then foment rebellion and revolution. On the plantations, the slaves were often forced to silence. Speaking was punished with the extirpation of the tongue. The loss of the original native language and the social pressures of assimilation resulted in the creation of the Creole, a mixture of African and European languages. The Creole, looked upon in the past literarily as a dialect, functions linguistically as a full-fledged, standardised native language. The Caribbean poet Grace Nichols, who is now living in Britain, connects the painful history and the fierce and proud recovery in her poem "Epilogue"26 (1990):

I have crossed an ocean

I have lost my tongue

from the root of the old one

a new has sprung.

Caribbean women poets use the full range of languages from Creole to Standard English. Facing the varieties of voices and attitudes towards the topic of mothering, I decided to choose the poems by Una Marson, Louise Bennett, Olive Senior, Lorna Goodison and Jean 'Binta' Breeze for my analysis. These poets represent Caribbean women's poetry of the twentieth century and assert a black feminist/womanist identity and voice that explores gender politics in a racist society.

\section{Una Marson (1905-1965)}

"But I know that black folk / Fed on movie lore / Lose pride of race. I would not have you so."

${ }^{26}$ Nichols, Grace. "Epilogue". $i$ is a long memoried woman. London: Karnak House, 1990. 85. 
Cinema Eyes

Brown Baby Blues

Biography and Publications

Together with Louise Bennett, Una Marson is a poetic model for Caribbean women poets. She was a journalist, playwright and poet. Writing in the 1930s and 1940s, she was the first female West Indian poet who explored the socio-cultural situation and the feelings of black women. Marson spent the years from 19321937 in England and returned in 1950. She worked as a secretary for the League of Coloured People and the exiled Ethiopian Emperor Haile Selasie. She was involved in the movements that led to the political independence of former British colonies in Africa and the Caribbean. She was also committed to the promotion of anti-racist philosophy. In England, she experienced the impact of racism and voiced her anger in her poem "Nigger" where she links the actual violence with the violence of language. She conceived and edited the influential BBC programme Caribbean Voices, which promoted the international recognition of Caribbean literature from 1945-1958. Later she founded the "Save the Children Fund". Her work was first published in London. Her books of poetry include, Tropic Reveries (1930), Heights and Depths: Poems (1931), The Moth and the Star (1937), Towards the Stars (1945). Information about her private life is scarce. One photograph represents her as a young woman with bobbed plain hair and elegantly dressed, sitting at a table and supporting a book with her left hand.

Una Marson and her Poetry

"Black is Beautiful."

Una Marson's poetry critically engages with the issues of cultural and gender politics. For a long time, her poetry has been criticised for weakness and imitation:

(Una Marson's) protagonists vacillate between the need to return to folk culture and yet retain their elite English traditions. [...]A feminist who attended the congress of the International Alliance of Women in the 1930s, Marson experimented with the use of Creole and blues forms borrowed from the southern United States in her poetry. (Edmondson 1999, 74-75)

Una Marson's feminist perspectives and her wide social sympathies appeal to the present time and recent re-readings point to the possibility of understanding imitation as an aesthetic of resistance and subversion. Alison Donnell's critical assessment in her essay "Contradictory (W)omens?: Gender Consciousness in the Poetry of Una Marson" (1995), guided my reading of Marson's poem "Cinema Eyes." In her early poetry, Una Marson used traditional forms of monologue, ballad, sonnet and a stylised language. In her later poetry, she was influenced by the Harlem Renaissance, the Black American cultural movement of the 1920s that 
concentrated on black issues with self-confidence and pride. She then experimented with Creole and jazz forms.

\section{Representation of Mothering and Children in her Poetry}

"My sweet brown baby / Don't you cry. / Your mama does love you / And your colour is high."

Marson's poetry points at black women's oppression in a patriarchal and racist society that forces them to perpetual preoccupation with their appearance. Her poem about a child speaks about the situation of the single mother and the mixraced child for whom she actively cared with her Save the Children Fund.

\section{Poems}

Cinema Eyes ${ }^{27}$

Don't want you to go to the Cinema -

Yes, I know you are eighteen,

I know your friends go,

I know you want to go.

I used to go to the Cinema

To see beautiful white faces.

How I worshipped them!

How beautiful they seemed -

I grew up with a cinema mind.

My ideal man would be a Cinema type -

No kinky haired man for me,

No black face, no black children for me.

I would take care

Not to get sun burnt,

To care my half indian hair

To look like my cinema stars.

I saw no beauty in black faces,

The tender light and beauty

Of their eyes I did not see;

The smoothness of their skin,

The mellow music of their voice,

The stateliness of their walk,

The tenderness of their hearts

No, they were black

And therefore had no virtue.

${ }^{27}$ Marson, Una. „Cinema Eyes“. The Routledge Reader in Caribbean Literature. Eds. Alison Donnell and Sarah Lawson Welsh. London and New York: Routledge, 1996. 138-140. 
A handsome youth came

To woo me at twenty;

I did not think him handsome then -

He was black and not my fancy.

I turned my back on him -

My instinct told me he was good and true,

My reason told me he was black

I turned my back on him.

Another came to woo me -

How fair he was! How like

My ideal built up in my heart -

I gave to him my heart,

My life, my soul, my all;

And how in hell he tortured me,

My dream lover - my husband -

Then you were born,

But I remained disconsolate.

He too saw no beauty in black faces,

You came dark like your grandmother;

He was peeved. I thought

You just a little like

My first handsome suitor

Who so long had gone away; -

He would have been more kind -

More tender - So I thought aloud

One day and he o'erheard me.

Soon this black god came from far

And called to greet me.

My husband, in fury and in drink,

Watched us as we talked -

And as he rose to go

Followed him calmly out,

And shot him, ere he reached the gate.

Another bullet sound,

And he too was gone;

And we were left alone.

I know that love

Laughs at barriers,

Of race and creed and colour.

But I know that black folk

Fed on movie lore

Lose pride of race.

I would not have you so. 


\begin{abstract}
Come, I will let you go
When black beauties

Are chosen for the screen;

That you may know

Your own sweet beauty

And not the white loveliness

Of others for envy.
\end{abstract}

It is accidental that the first poem of the Caribbean section has a topic similar to the first poem in the Indian part. Marson's "Cinema Eyes" can be compared to Kamala Das' poem “An Introduction.” A mother gives her eighteen year old daughter the important instruction that she must accept and love herself and her body. The poem is written in form of a ballad with repetitions of words and lines that tell a violent story in an apparently simple way: deformed by cinema's promotion of white beauty, a light-coloured woman rejects blackness. She turns away from her first black suitor, marries a fair-skinned man, who treats her badly and is jealous and suspicious because the daughter is dark black. In the end, he shoots the first suitor and himself. The poem works with contradictions. "Cinema eyes" and a "cinema mind" should be pre-occupied with white beauty which is, however, only referred to as "beautiful white face". But the poem praises the physical presence of black women in abundance, "the smoothness of their skin", "the mellow music of their voice", the "stateliness of their walk", and also their beautiful character "the tenderness of their hearts". Although the speaker of the poem ruefully returns to the true values of her race, she still remains partly in the stilted language of British middle-class which she must have heard in the cinema or keeps in her memory from the literature of the British educational system in the colonies. With words like "suitor", "disconsolate", "ere", Marson both demonstrates and parodies her knowledge of tradition. Her laughter subverts the power of tradition and colonial education. Una Marson was a progressive woman. She praised black beauty as powerfully as the Black Power Movement with the slogan "Black is Beautiful" in the 1960s. Una Marson's poem tells us that and how Frantz Fanon's notion of Black Skin, White Mask influences feeling and thinking of black women. This mother knows from the experience of her own life how disastrous it is to educate a black child to envy and to strive for the physical characteristics of the white. A lesson for more self-confidence and self-assurance is always an important lesson for a child's psychic development and sanity, and still much more in a racist society. Even today Fanon's observations are not outdated. Many fashion magazines for black women prefer women with light-skin and straight hair and reject African features. 
Brown Baby Blues ${ }^{28}$

I got a brown baby

Sweet as she can be.

I got a brown baby

Sweet as she can be.

But she ain't got no papa,

Cause he's gone to sea.

I love me baby

But she don't got no name.

I love me baby

She don't got no name.

Well wha'fe do,

Dat is not her shame.

Maybe she'll ask me

Why I is so black,

Maybe she'll ask me

Why I is so black,

An' she's so brown;

Lord, send her papa back.

My sweet brown baby

Don't you cry.

My sweet brown baby

Don't you cry.

Your mama does love you

And your colour is high.

The speaker of the poem is a black woman who laments her present situation as single mother and who imagines the future of her mixed-raced child. The blues form with its repetitions and improvisation is a precise expression of this mother's thoughts that circle always around the same pre-occupations: "I got a brown baby / Sweet as she can be", "Why I is so black, / An' she's so brown." The blues song often invokes God and presents a conclusion at the end. This mother sings a real blues: "Lord, send her papa back", "Your mother does love you / And your colour is high." The poet attempts to capture the voice, the rhythm and tone of the blues through her words. The situation of this song is similar to the moment described by the African American poet Langston Hughes in his poem "The Weary Blues"29:

\footnotetext{
28 Marson, Una. "Brown Baby Blues". Up from Under: Poetry by Women from the West Indies and the Diaspora. Ed. Gordon Collier. Berlin: Humboldt University, 2002. 43.

${ }^{29}$ Hughes, Langston. „The Weary Blues“. The Norton Anthologyof American Literature. Fifth Edition / Volume 2. Ed. Bruce Michelson. New York/London: W. W. Norton \& Company, 1998. 173.
} 
Droning a drowsy syncopated tune,

Rocking back and forth to a mellow croon, I heard a Negro play

One has just to change the last line in "I heard a black mother's lament." The blues reconciles grief and defiance in the face of pain. To sing of suffering and sorrow was to communicate pain and to recover from it. The voice of the blues speaks for the oppressed and abused people everywhere and becomes a tool for survival. A re-reading of Una Marson's poem "Cinema Eyes" reveals parody as political tool of resistance in her adaptation of British literary forms and her use of sophisticated words. My reading of Una Marson's poetry, however, does not aim at forcing feminist criticism on her poems in order to press a political statement out of them. But it points at the possibility that colonial and postcolonial literature guide us to question our theories. Our next woman poet uses the subversive power of parody in her poetry in a different way. Louise Bennett works with dialect and laughter.

\section{Louise Bennett (*1919)}

"De gal pupa dah-laugh an sey / It serve "Merica right / Five years back dem JimCrow him now / Dem pass him pickney wite."

Bed-time Story

Pass Fe White

Proverbs

Biography and Publications

Louise Bennett is the pioneer in the oral tradition of Caribbean poetry in the twentieth century. Born in Kingston/Jamaica, she began writing and performing poetry already as a teenager. She established herself as a leading performer and scriptwriter in the Jamaican Little Theatre Movement. In 1949, she moved to London where she studied drama at the Royal Academy of Dramatic Arts and worked as a resident artist with the BBC. Her poems were featured on the Caribbean Voices programme of the BBC. She returned to Jamaica in 1955 and worked as drama specialist with the Jamaican Welfare Commission. In the 1960s, she lectured in drama and Jamaican folklore at the University of the West Indies.

As "Miss Lou", the persona of her poems, she has become Jamaica's most famous poet and performer on TV, radio and on the stage. Her records of poems, folk songs, stories and singing games have been highly popular in Jamaica. Photographs show her as a stout and resolute woman dressed in colourful traditional African clothes. Although Louise Bennett always described herself as a writer first, she had to wait for serious recognition and substantial publication until the 1960s when Independence increased the search for a characteristic Caribbean expres- 
sion. Her books of poetry include Jamaica Dialect Poems (1948), Jamaica Labrish (1966), Selected Poems (1982).

\section{Louise Bennett and her Poetry}

"She is sane; throughout, her poems imply that common sense and generous love and understanding of people are worthwhile assets."

Louise Bennett has been influenced by Claude McKay's poetry. As a young girl, she won a copy of his poems as a school prize. Claude McKay was one of the first Jamaican poets to bring the vernacular into the literary tradition, but it was the language and the presentation as performance that denied her poems literary value. Mervyn Morris' contribution “On Reading Louise Bennett, Seriously” (1967), was the first scholarly essay to validate Bennett's art and the literary use of creole. One should mention that Mervyn Morris is a poet himself. He wrote:

I believe Louise Bennett to be a poet. By many people [...] she is regarded more or less a local joke; a good, high-spirited joke, but, in the end, only a joke. I believe it is time we took Louise Bennett more seriously; and the purpose of this essay is to suggest literary reasons for doing so. [...] I do not believe that Louise Bennett is a considerable poet. [...] She does not offer her readers any great insights into the nature of life or human experience but she recreates human experience vividly, delightfully and intelligently. She is rarely pretentious; [...] she is not derived from other poets - she has her own interesting voice; and she is invariably sane. (...) She is sane; throughout, her poems imply that common sense and generous love and understanding of people are worthwhile assets. (Donnell and Welsh 1996, 194-197)

Since Louise Bennett's use of the Creole and her art of performance have influenced many women poets, we must pay attention to her comments in an interview with Dennis Scott in 1968. Scott is a playwright and poet and later became director of the Jamaica School of Drama and of the Cultural Training Centre in Kingston. The conversation is mostly concerned with the two main characteristics of her poetry: laughter and dialect and the relation between them. Since I have been working in Africa, the question of laughter intrigues me. I have always admired and envied Africans who are able to laugh and to make comic, ironic, satiric comments at the most serious conditions and infliction. Since Louise Bennett offers explanations and insights, I deliberately quote at length from the interview "Bennett on Bennett" between Louise Bennett (LB) and Dennis Scott (DS):

DS: Louise, I heard you say once - 'I believe in laughter.' this is one way, your way of looking at the world, but tell me, how far does your use of dialect depend on this attitude?

LB: I have found a medium through which I can pretend to be laughing. Most of the time that we laugh it is so that we may not weep. Isn't that so?[...]

DS: And do you feel that this inability to be serious without being funny as well is a particular quality connected with people of negro origin? It certainly is there in 
the American blues tradition, in the whole field of jazz. Even when you are closest to tears there is a bit of an ironic twist in your expression - there is joy as well

LB: [...] I don't care whether people agree with me or not; I find that the negro people have the greatest capacity for forgiving of any people I can find anywhere. I can't think of any other race that has suffered as much as the negro has all over the world that could behave as the negro does, the ordinary negro -knowing what is happening and has happened to negroes all over the world. To behave as we do, to laugh at things as we do - well really! To make fun of ourselves and other people as we do in the midst of unhappiness! [...] One reason I persisted writing in dialect in spite of all opposition was because nobody else was doing so and there was such rich material in the dialect [...] being interested in people and what the people were doing and the 'now' of their lives, these were my preoccupations and the themes I tried to develop. [...] Our people - the people that I keep on studying and portraying - they have such a wonderful sanity and clarity in their language - though it's not 'acceptable'! [...]

DS: One last question then - Because of this quality of laughter in your work it is easy sometimes for us, for the audience to miss the social seriousness, the serious social intent behind the work. Is this true and is this deliberate on your part?

LB: This is true. Many people do miss it. Sometimes their missing of the point is deliberate. They prefer to pretend that's all in fun. And I don't mind. I go along with them. As long as I myself am sincere about what I am doing I feel that the truth of a thing must reveal itself to the right people.

DS: And are you content with this situation? Would you like people to see what's behind the humour as well? More people, I mean.

LB: Yes, I would, but I know that it takes time.

DS: And about anger finally. Is your work 'angry'?

LB: (Pause) Not obviously. Not obviously angry.

Let us now use these explanations for the analysis of three poems in which mothers and children play a role. One deals with the black/white dualism, the other two with maternal activities of telling a bed-time story and of taking care of the proprieties.

\section{Poems}

\section{Bed-time Story ${ }^{30}$}

Ah long fi see yuh tell ah short!

Whe yuh deh all dis time?

Dah pickinnini yah woan go sleep,

She waan me tell her rhyme.

30 Bennett, Louise. „Bed-time Story“. The Routledge Reader in Caribbean Literature. Eds. Alison Donnell and Sarah Lawson Welsh. London and New York: Routledge, 1996. 146. 
Mary had a little lamb

Miss Mattie li bwoy joe

Go kick May slap pon har doorway -

His feet was white as snow.

An everywhere dat Mary went

Him modder never know,

An when she ear she ongle seh -

De lamb was sure to go.

She ongle seh de bwoy too bad

An tell May nuffi bawl

Jack and Jill went up de hill -

An dat was all an all.

May mighta go to hospital

-To catch a pail of water;

Jack fell down an bruck him crown -

Jus like Miss Mattie daughter.

Yuh never know de baby bawn?

Him pa gi him name Marta.

Teng God him drop eento a doze

An Jill come tumblin after.

Louise Bennett's bedtime story undermines our expectations from a nursery rhyme, which it parodies in a haunting way. It describes the usual situation: a mother, the speaker of the poem, is asked to tell a story before the child goes to sleep. She tries to breathe a sigh of relief, but she is still angry. Her child had run away, she had lost control and remembered what had happened to children in her neighbourhood:

Miss Mattie li bwoy joe

Go kick My slap pon har doorway -

Him mother never know,

An when she ear she ongle she -

She ongle seh de bwoy too bad

An tell May nuffi bawl

May mighta go to hospital

Jus like Miss Mattie daughter.

This mother is more inclined to tell a street ballad of murderous deeds as a warning - similar to the German "Shock-headed Peter":

Jack and Jill went up the hill -

To catch a pail of water -

Jack fell down and bruck him crown -

An Jill came tumblin after. 
But this might cause a nightmare and the mother manages to tell a traditional and "really" comforting bedtime story:

Mary had a little lamb

His feet was white as snow

An everywhere dat Mary went

De lamb was sure to go.

An dat was all an all.

In the end, the mother includes the father and turns to the reality - or the dream of a complete and happy family. She fulfilled her task: the child is sleeping. But the disturbing presence cannot be glossed over by a pious speech: the incident of Miss Mattie's little boy Joe remains in the foreground and the shock-headed Peter has the last word, which, by the way, rhymes suitably:

Yuh never know de baby bawn?

Him pa gi him name Marta.

Teng God him drop eento a doze

An Jill come tumblin after.

With the contrast of its three strands of narrative, this poem reveals the violent Jamaican society and contradicts dreams of an innocent and idyllic childhood. Louise Bennett's subversive use of nursery rhymes has influenced dub and Rastafarian poets, for example Michael Smith's "Mi Cyan Believe It" (1981). Michael Smith's tragic fate reminds us of the urgency to prevent violence. Born in Kingston in 1954, he was stoned to death during an election campaign in 1983 in his home country Jamaica. This bedtime story leaves one's laughter stick in one's throat. The next poem leaves us, perhaps, with a smile of malicious joy on our face.

\section{Pass Fe White ${ }^{31}$}

Miss Jane jus hear from 'Merica, Her daughta proudly write

Fe sey she fail her exam, but

She passin' dere fe wite!

She say fe tell de truth she know

Her brain part not so bright,

She couldn' pass tru college

So she try fe pass fe wite.

She passin wid her work-mate dem,

She passin wid her boss,

An a nice wite bwoy she love, dah-

Gwan wid her like sey she pass.

${ }^{31}$ Bennett, Louise. "Pass Fe White". Jamaica Labbrish. Jamaica, J. W.: Sangster's Bookstores Jamaica, 1996. 212-213. 
But sometime she get fretful an

Her heart start gallop fas'

An she bruk out eena cole-sweat

Jus a-wonder ef she pass!

Jane get bex, sey she sen de gal

Fe learn bout edication,

It look loke sey de gal gawn weh

Gawn work pon her complexion.

She noh haffe tan a foreign

Under dat deh strain an fright

For plenty copper-colour gal

Deh home yah dah-play wite.

Her fambily is nayga, but

Dem pedigree is right,

She hope de gal noh gawn an tun

Noh boogooyagga wite.

De gal pupa dah-laugh an sey

It serve 'Merica right

Five year back dem Jim-Crow him now

Dem pass him pickney wite.

Him dah-boas' all bout de districk

How him daughta is fus-class

How she smarter dan American

An over deh dah-pass!

Some people tink she pass B.A.

Some tink she pass D.R.,

Wait till dem fine out sey she ongle

Pass de colour-bar.

In several poems, Louise Bennett humorously deals with aspects of migration: She depicts the migrant who changes accent, style and even colour; the host society, especially Great Britain, that suffers "Colonisation in Reverse"; and political movements in search of roots in "Back-to-Africa." This poem parodies the preference of a white complexion and gender roles: Miss Jane's daughter, studying in the United States, did not pass her exams but has to her credit that she 'passed' there as white. The mother, proud of her black family ("Her family is nayga, but / Dem pedigree is right"), would have preferred an educated daughter. She is afraid of getting back a "boogooyagga" = good-for-nothing white. Her apprehensions resume her prejudices against white women: they misuse their relation with men in order to promote their career ("She passin wid her work-mate dem,/ She passin wid her boss,"); they are superficial and only concerned with their appearance ("It look loke sey de gal weh / Gawn work pon her complexion.”). The father, in contrast, is proud of his daughter. The racist laws, "Jim Crow", had turned down 
his immigration some years ago. Now his daughter has cheated America ("Five year back dem Jim Crow him now / Dem pass him pickney wite.") His daughter's "success" is his revenge. Louise Bennett's iambic quatrain with its ABCB rhyming scheme is deceptively simple. But "Pass Fe White" demonstrates its poignancy through the rhymes: white - the highly estimated characteristic of racial difference - rhymes awkwardly: "her brain part not so bright / So she try fe pass fe wite", "fright / wite", "right / boogooyagga wite." "It serve "Merica right / Dem pass him pickney wite." A parody of racism is a liberating act which is used in contemporary popular culture. A short derivation may serve as an example. After many personal tragedies concerning his racial and sexual identity, pop-star Michael Jackson reached this liberation, hopefully not only for a short time, and parodied racism. In his recent shows, he doubly subverted minstrel performances of the nineteenth century where black-faced white men forged enduring stereotypes of black people as clumsy, stupid and obsessed by dance and music. Jackson appeared white-faced and with white gloves performing his perfect dances. In her next poem, Louise Bennett works with proverbs, another primary oral form.

\section{Proverbs $^{32}$}

'When ashes cowl dawg sleep in deh';

For sence Ma dead, yuh see,

All kine a ole black nayga start

Teck liberty wid me.

Me no wrap wid dem, for me

Pick an choose me company:

Ma always tell me seh: 'Yuh sleep

Wid dawg yuh ketch him flea.

Me know plenty a dem no like me,

An doah de time so hard

Me kip fur from dem, for 'Cockroach

No biniz a fowl yard.

Ah teck time gwan me ways an doan

Fas eena dem affair;

Me tell dem mawnin, for 'Howdy

An tenky bruck no sqare.

Sometime me go a parson yard

Sidung lickle an chat -

,Ef yuh no go a man fir-side, yuh no know

Ow much fire-stick a bwile him pot.'

Sake - a dat, as lickle news get bout

Dem call me po gal name;

32 Bennett, Louise. "Proverbs". The Routledge Reader in Caribbean Literature. Eds. Alison Donnell and Sarah Lawson Welsh. London and New York: Routledge, 1996. 147. 
Me bear it, for doah 'All fish nyam man,

Dah shark one get de blame.

But when me go look fi parson

Me ongle talk bout me soul,

For Ma use fi tell me: 'Sweet mout fly

Follow coffin go a hole.'

Das why ah miss me mumma, yaw:

Ef she wasa live tedeh

All dem liberty could teck wid me,

Dem couldn a seh me seh.

She was me shiel an buckler,

She was me rod an staff.

But 'Back no know weh ole shut do fi i

So tell ole shut tear off.'

Louise Bennett uses proverbs as topical and structural element of her poem. The speaker of the poem is a young woman longing for her dead mother because she still needed her as a chaperon against male liberties. The task of a mother to guide her daughter to adulthood is attached to a dead mother. Probably her late mother had never given real instructions about sexuality and relation between women and men, but had commented in proverbs in order to deliver moral or religious judgement. Now the helpless young woman echoes her mother and comments on her present experience with the proverbs she remembers. Proverbs are a shared knowledge of the speaker and the interlocutor, the poet and her audience. They are even regarded as "treasure" of common sense. In this poem, proverbs comment on death and mourning and on the relationship between women and men. The ostensibly naive speaker complains of a certain aggression between women and men which is both sexual and social in origin. Proverbs work as a means to release tension. But the excessive use of proverbs and the obvious "malapropism" also parodies their function to generalise the individual experience. Louise Bennett makes comedy out of an originally sad moment and a dark period of life. In her interview, she speaks about this ability:

Take the folk songs, for instance, do you remember 'London Torbun'? It's a sad tale, but because a Jamaican does not dwell on the sorrow of an occasion exclusively, the song is not a sad one so it has a feeling of lightness and cheerfulness and on first hearing sounds like almost a child's nonsense song. [...] And of course it's all part of another tradition - the practice of singing a 'dinky' to cheer up the family of a dead person so that they don't cry. What is interesting is that when you look between the lines you will find all the sorrow there and all the facts too, but if you don't search for it, if you don't care, well then, you won't find it. (Markham 1989, 49.)

In her poems, Louise Bennett tells stories or uses the dramatic monologue to pursue an argument. She makes as laugh first and then conscious that we have 
laughed at the ambivalence of the comic scene. Her subversive use of popular forms - nursery rhymes and proverbs - allows her to criticise social problems without undue explanation and to transcend the personal experience. The three poems, taken as examples, tell about mothers and children and call against the racism and violence of the Jamaican society. They contradict Louise Bennett's last answer in her interview: they are far more angry than funny. But does she really contradict? Louise Bennett pauses before she answers. She has told us before that we have to listen to the ambivalence of black speech.

The use of Creole is limiting. This limitation applies still more to the written form than to the performed. The close analysis of the text reveals the sophisticated art under the deceptive simple surface, but it can never substitute the spoken word and equal the joy and pleasure transmitted by a performance. Louise Bennett's poems helped me to understand better the inclination of African's to laughter and storytelling. I am grateful to her. A short glossary of Creole is attached, not only to facilitate the translation of Louise Bennett's poems but for the following women poets as well who switch between Creole and Standard English.

Some features of Creole grammar: no indications of tense or aspect; thirdperson singular without -s, absence of articles and object-pronouns, nominal possessive constructions, for example "he back" for "his back".

Some vocabulary: $a$ or $a h=$ is or to $/ / a$-, $=$ it is, there are $/ / a x$ or $a k s=$ ask $/ /$ boogooyagga $=$ good-for-nothing, socially awkward person // bwoy $=$ boy $/ /$ dem $=$ them $/ /$ dis- $a$ or dis-yah $=$ this very, this here $/ /$ doan $=$ don't $/ /$ eena $=$ in $/ /$ fah $=$ for $/ / f e=$ for $/ /$ gi=give $/ /$ gwan $=$ go on $/ /$ gwine $=$ going to $/ /$ hooda really $=$ would really $/ /$ hooden $=$ wouldn't $/ / i^{\prime}=\mathrm{it} / /$ kea $=$ carry $/ /$ kip $=$ keep $/ /$ koo $=$ look // koo yah =look here $/ /$ labrish = gossip, chatter $/ /$ lacka $a=$ like $/ /$ leggo $=$ let go // mell=trouble // mo=more // mussa $=$ must be // nayga $=$ Negro, "nigger" // naw $=$ not $/ /$ ninyam $=$ food $/ /$ noan $=$ none $/ /$ nob $=$ no $/ /$ nyam $=$ eat $/ /$ oonoo $=$ you $/ /$ omuch=how much $/ /$ ongle $=$ only $/ /$ pickney $=$ child $/ /$ sey $=$ say $/ /$ siddung $=$ sit down // sinting=something // web=where / wi=will // yab or yaw= you know, truly // yeye $=$ eye $/ /$ yub= you.

\section{Olive Senior (*1943)}

"rainfall scatters the playing children with the cutting edge of raindrops vietnamese bamboo trees provide frail cover from the breeze from the green rain."

Birdshooting Season

One Night, the Father

The Mother

Childhood

rain 
Biography and Publications

Olive Senior was born in Jamaica in 1943 into a family with African roots. She is fairly light-skinned. In an interview with Anna Rutherford in 1986, she revealed that she lived through many directions and contradictions in her childhood divided between two homes: a village "dark-skin" and a "light-skin" middle-class urban environment. She mentions the oppression of a restricted narrow Christianity. She studied in Jamaica and in Canada. She is managing director of the Institute of Jamaica Publications and of Jamaica Journal. She received the Institute of Jamaica Centenary Medal for Creative Writing. Her publications include one book of poems Talking of Trees (1985), several collections of short stories Summer Lightning and Other Stories (1986), Arrival of the Snake-Woman and Other Stories (1989), Discerner of Hearts (1995), critical essays on poets and poetics and a book on the roles and status of Caribbean women, Working Miracles - Women's Lives in the Englishspeaking Caribbean (1991).

Olive Senior and her Poetry

"Jamaica is still a society of great spirituality, of great psychic energy."

In her interview, Olive Senior mentions that she started writing as a child because it served as therapeutic purpose, but she soon moved from this "subjective stage to a consciously objective pursuit of writing as a craft" (in Markham 1989, 213). She characterises herself as a storyteller who listens to the sound of the voice due to her early experience of growing up in an oral culture. Several of her poems develop a humorously subversive stance. Her language switches between Standard English and rare use of a polished Creole. She uses European models and African myths. Senior is regarded as one of the most accomplished Caribbean poets together with Derek Walcott. Searching for a correspondence between poetic form and content, her poems draw attention to display, vocabulary and imagery, but the delicacy and discipline of her minimalist style draws attention to the ambivalence of pure art and calls for an anti-elitist and political interpretation. In her recent long prose or narrative poems, she blurs the boundaries between both genres.

\section{Representation of Mothering and Children in her Poetry}

"Little girls whispering: / Fly Birds Fly."

Olive Senior is not married and has no children, yet she is one of the few women poets who depict family life: the relation between wife and husband, women and men in their roles as parents and their attitudes towards their children. She argues that Caribbean women, often described as powerful and strong, are weak in their relationship with men because they are still socialised according to traditional patriarchal family structures. Social and economic conditions lead to the violence of men who act out their frustration and exhaustion on their wives and children. 
Poems
Birdshooting Season ${ }^{33}$
Birdshooting season the men make marriages with their guns My father's house turns macho as from far the hunters gather
All night long contentless women stir their brews: hot coffee chocolata, cerassie wrap pone and tie-leaf for tomorrow's sport. Tonight the men drink white rum neat.
In darkness shouldering their packs, their guns, they leave
We stand quietly on the doorstep shivering. Little boys longing to grow up birdhunters too Little girls whispering: Fly Birds Fly.

This poem describes the male sport-event of bird-shouting from a feminist point of view. The poetic device of alliteration is used to characterise men and women. On one side: "men make marriage with their guns / My father's house turns macho". On the other side: "contentless women stir their brews: hot coffee, chocolata, cerassie". Women serve their men. The children stand apart, "quietly", "shivering", "whispering". Nobody cares for them. Little boys take their fathers as role models. Little girls still care for the victims. But they subconsciously criticise both father and mother, they only dare to whisper. This poem humorously criticises incarcerated gender roles: the man remains the hunter from Stone Age. The woman born as caring and modest creature seems to have no brain and to lose empathy as an adult. Middle-class women are mindless and support the macho roles of their men. They have no voice. Their silence is a gesture of indifference. In the next poem, silence is the helpless gesture of those who cannot escape their reality.

The Mother ${ }^{34}$

Muma mi belly soon grow bed so small
One Night, the Father ${ }^{35}$

One night the father

\footnotetext{
33 Senior, Olive. "Birdshooting Season". Hinterland - Caribbean Poetry from the West Indies and Britain. Ed. E. A. Markham. Newcastle upon Tyne: Bloodaxe Books Ltd., 1998. 217.

34 Senior, Olive. "The Mother". Up from Under: Poetry by Women from the West Indies and the Diaspora. Ed. Gordon Collier. Berlin: Humboldt University, 2002. 71.

35 Senior, Olive. "One Night the Father". Hinterland - Caribbean Poetry from the West Indies and Britain. Ed. E. A. Markham. Newcastle upon Tyne: Bloodaxe Books Ltd., 1998. 222-223.
} 


last night Uncle Paul
bizniz with me
didn't know till he done -
Hush yu mout little gal
have no right
talk such nonsense
how come yu so shurance
and force ripe. Uncle Paul
help with school fees
and dress say he like
- what go on
under cover

girls look nice when they go off to school

Muma no school today mi body a hot me. Mi head dis a grow muma beg yu no lash me

One night you even say yu own father did try O god pickney nowadays so wicked and lie split

a house

in two

one side

the only

sound the

mother

weeping

weeping

the other

ricochet

of bullets

butchering

banana leaves.

One night

the father

held them

in a state

of siege.

Furniture

loomed

barricades

against

the door

as in

war lore

each child

thought:

this bullet

is meant for me.

One night

the neighbours

said a

drunken brawl

is all

the mother

shouted

an obstinate

No.

When the father

spent the bullets

for them he'd

also spent

himself.

Came 


like
a dried
canestalk
trashed
by hooves
of obstinate
mules
turning
the cane mill
round
round
till
the day
the father
finally
broken
became
part of
that ground.

"The Mother"

In some of her poems, Olive Senior uses dramatic monologues. Her poem "The Mother" forces the reader to overhear a talk in Creole between a black mother and her daughter. The girl tries to tell her mother about sexual abuse, certainly committed by her Uncle Paul and possibly by her father. She already senses that her mother would rather punish her than help her: "beg yo no lash me". When her daughter needs a comforting word or an embrace, the mother only silences her. The mother knows, probably from her own childhood, what is happening, but she wants to keep up appearances: "what go on under cover". Her daughter has to learn that nothing is for free in this life: "Uncle Paul help with school fees and dress say he like girls look nice when they go off to school." Uncle Paul deserves some gratification and the girl has to bow to the inevitable.

As long as "morality means the effective concealment of crime", to use the words of Kamala Das, women poets have to denounce sexual abuse, rape and incest because children have no voice. Olive Senior's use of dialogue puts the reader in the precarious situation of an involuntary eavesdropper who overhears a talk that is meant to remain secret, "under cover". But the message calls for intervention. What should we do: keep ourselves outside the affair, remain indifferent, interfere, denounce? This poem effectively depicts everyday experience. Children seem to die so suddenly, after they have been starved or beaten to death over years. But nobody had noticed it. This poem conjures up memories from my work as a doctor. I remember the five-year-old girl with the sexually transmitted disease, who came with her mother, and the two three- and four-year-old brothers with bleeding genitals: two small naked boys running through an Indian slum to our 
ambulance, crying for protection from perverse manipulations. They came alone because nobody in the family or the neighbours wanted to be asked to testify. It is so difficult to protect children because societies continue to silence them. Olive Senior's poem on a mother who does not act according to our expectations of how a good mother should act brings this silence to an end.

\section{"One Night, the Father"}

This poem appears as a long vertical line on the page. The poem contains 65 lines comprising four stanzas of nine to 23 lines. The lines consist of one to at most three words. The four stanzas present the story of a father running amuck in four stages. These facts are told like a report in unemotional and identically structured and placed sentences:

"One night the father split the house in two."

"One night the father held them in a state of siege."

"One night the neighbours said a drunken brawl is all."

"When the father spent the bullets for them he'd also spent himself."

The repetition, the parallelism of the lines and the characteristics of the syntax make the isolation of the father visible and the monotony of his life. His bizarre actions can be heard and seen: he butchers banana leaves with bullets, he builds the furniture as barricades against the doors, he attempts a shootout with the family. But nobody really notices all this. The third stanza, at the poem's centre, is the shortest with only nine lines and the only one with reported speech: "The neighbours said a drunken brawl is all", "the mother shouted an obstinate No". The mother, "weeping, weeping" in the first stanza, does not dare to raise her voice against her husband but tries to keep up appearances. The final stanza gives a reason for this tragedy with a summary of the father's life: "Came like a dried canestalk trashed by hooves of obstinate mules turning the cane mill round round." At the end the o-sounds prevail. They bewail the father's tragedy and lead dramatically to the poem's end: "the father finally broken became part of that ground." The last image alludes again to the father's sexuality and violence. The mother and the mules both are characterised as obstinate. This connection points at Zora Neale Hurston's famous statement: “The nigger woman is de mule ah de world". In her novel Their Eyes Were Watching God (1937), the protagonist Janey develops her dreams and way of life against the situation depicted by her Nanny:

Honey de white man is de ruler of everything as fur as Ah been able tuh find out. Maybe it's some place way off in de ocean where de black man is in power, but we don't know nothin' but what we see. So de white man throw down de load and tell de nigger man tuh pick it up. He pick it up because he have to, but he don't tote it. He hand it to his womenfolks. De nigger woman is de mule uh de world so fur as Ah can see. (Hurston 1986 [1937], 29) 
The poem "One Night, the Father" makes a man visible who is straightaway falling into the abyss. A human being is driven into madness and catastrophe, yet nobody intervenes. In all three poems, violence is represented by men or maleness, yet Olive Senior does not condemn men. She expresses her empathy with both women and men. Her poems on mothers include the fathers and the whole family. This is a womanist stance, but these poems are likewise feminist because they make a claim for women's voice. With her representation of violence within the family, Olive Senior calls out against indifference and silence in the face of violence. She brings an end to this silence which is the gesture of those who refuse to or give up exploring their reality. Although her depiction of family life seems rather depressing, she is not pessimistic in her interview:

The economic conditions contribute to a lot of what happens in the home and ultimately on the street. And yet, having said all this, I also feel - and I believe that this also comes out in my work - that there is in our society still a great deal of love, of caring, of good fellowship, of kinship and friendship bonds which are strong and long lasting. Jamaica is still a society of great spirituality, of great psychic energy. (Markham 1989, 216)

The next poem seems to recall childhood memories:

\section{Childhood ${ }^{36}$}

Rivers flow red and swollen with the clay

of upstream mountains where the

rain falls. Mocking birds call

in the woods from the roseapple tree

echo the cry of crazy-lost children

and the bird-filled hills fear still

sudden death. By slingshot.

The dead in a certain graveyard

cannot rest again after a long ago

awakening when Sunday School children

hunted cashew nuts on the way to church

and wept over penny-for-the-collection-plate

lost in the crack of the tombs.

At the river Job's Tears wait still

eager hands seeking treasure

for stringing and logwood blossom boats

float as far - Falmouth - or China - bringing

a fleet of magical ships to all

lingering downstream. The day

could turn magic. From the river

tables rise and rivermaids comb

${ }^{36}$ Senior, Olive. "Childhood". Hinterland - Caribbean Poetry from the West Indies and Britain. Ed. E. A. Markham. Newcastle upon Tyne: Bloodaxe Books Ltd., 1998. 220. 
their hair golden in the afternoon

singing.

Several Caribbean writers have drawn on childhood experience. A famous example is Derek Walcott's Another Life (1973), where the poet describes how his childhood was shaped by the unique Caribbean environment, culture and history. Migration separated several writers from their home country. Their poems about childhood are written like pastorals yearning for the happiness and innocence of a rural childhood and recording the love for family, friends and partners. Olive Senior's poem stands in opposition to this common form of childhood memories. The insertion of the "comment", "The day could turn magic", frames the moment and puts emphasis on the literary practice. Senior uses literary allusions to show that our relation to childhood is something that we cannot grasp, but that we make up and remake.

In this poem, the image of the river stands for the course of time. Fragments of fairy tale, of religious superstition and of adventure story intermingle with allusions to personal memories and describe two different levels of time. The memories of one day in childhood are juxtaposed to the remembrances of a whole lifetime. The poem consists of three stanzas of six to ten lines. The first stanza begins with the fairy tale of 'crazy-lost children' in the woods. The third stanza ends with the tale of rivermaids combing their hair golden. The first and third stanzas are structured by images of water, river and rain:

"Rivers flow red and swollen with the clay / of upstream mountains where the rain falls."

"At the river Job's Tears wait still / eager hands seeking treasure / for stringing and logwood blossom boats / flow as far - Falmouth - or China - bringing / a fleet of magical ships to all / lingering downstream." [...] "From the river / tables rise and rivermaids comb / their hair golden in the afternoon / singing."

The second stanza, at the poem's centre, creates a spectre: children's play on the way to Sunday school awakens a dead who will never come to rest again. Did the spectre of the dead drive the children into the woods? How do Sunday school and fairy tales intersect to induce a nightmare?

In the first stanza, water and rain signal death and complications and create the danger of losing one's way, getting astray. In the third stanza, the river is connected to mysteries - treasure and logwood blossom boats - and activities. On the one hand, a child seems to have escaped from the haunting admonitions of the Sunday school to the fascination of an adventure story. On the other hand, the verbs describe the continuous claims and moods of adulthood: "seeking", "stringing", "bringing", "lingering". A "comment" on the memories interferes - somehow subdued and crammed between the second and the third part: "The day could turn magic." For an imaginative child this could be a promise to continue 
and to escape to the seduction of singing rivermaids. It is a change from all distractions to something simple. The complications are gone: rivermaids, creatures of a woman's head and a fish's body are sexless, simple and beautiful. The image creates the impression of innocence, safety, abundance and pleasure. But for an adult person, it seems to entail an ironic gesture or a warning. The poem reveals the fairy-tale-like character of our childhood memories. We forget the chaos and the mental darkness of the woods from the beginning of the poem and end up with nostalgic dreams. We seem to resemble the rivermaids: they comb their hair golden in the afternoon singing; we do the same with our childhood memories in the afternoon of our lives.

This complex and delicate poem speaks about the fragility and vulnerability of a sensitive child's soul. This child tries to come to terms with religion and loneliness. She remains without the help of an adult person. There is no mother or father around. The speaker of the poem seems to have been alone from childhood on. In her interview, Olive Senior remembers the burden of poverty and of a narrow Christianity:

Yes. I felt more oppressed by religion as a child than I did by anything else. A very restricted, narrow kind of Christianity combined with poverty is, I think, a ruthless combination, in that both attack the spirit, they are both anti-life, they are both anti-freedom, soul-destroying as far as I am concerned. My whole childhood, adolescence, early adulthood were spent - wasted, I feel - trying to transcend these. (Markham 1989, 213)

In her poem "Childhood", Olive Senior explores again the theme of isolation. She also examines the power of literature and fiction on the whole. She points at the danger of an affected behaviour and of an inner solitude if art is taken as a refuge. Children of our contemporary world and the function of poetry are the concern of her next poem "rain."

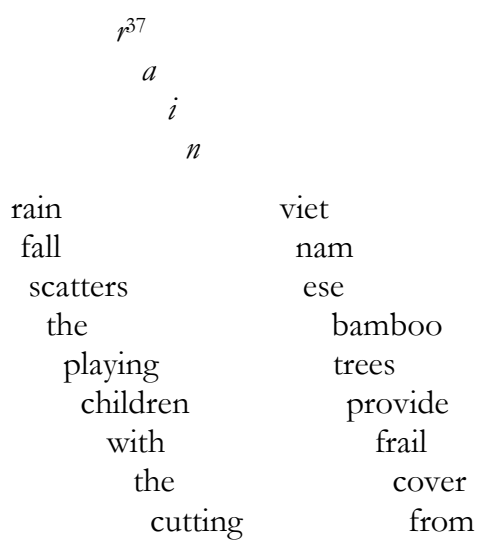

${ }^{37}$ Senior, Olive. "rain". Hinterland - Caribbean poetry from the West Indies and Britain. Ed. E. A. Markham. Newcastle upon Tyne: Bloodaxe Books Ltd., 1998. 226. 


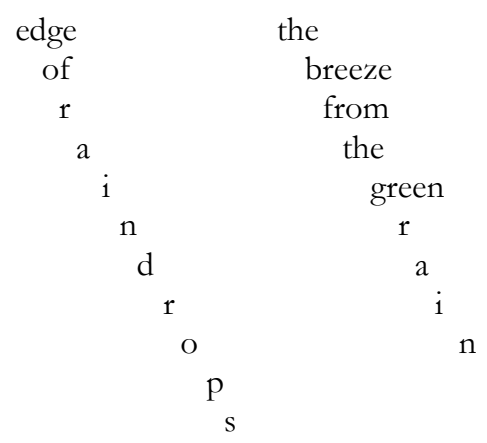

The poet transforms Guillaume Apollinaire's famous emblematic poem "Il Pleut" 38 into an anti-war poem. Visually, it also gives the impression of a beautiful Chinese ink drawing. In Olive Senior's poetry collection Talking of Trees (1985), Bertolt Brecht's question is the source of the title and is used as a superscription to a section of the book:

What kind of period is it,
when to talk of trees
is almost a crime
because it implies silence
about so many horrors?

Her poem is an attempt to answer Brecht's question and also Theodor Adorno's famous remark about the impossibility of lyric poetry after Auschwitz. She adopts the perfect aesthetic form and fills it with the salient incidents of the war in Vietnam. Rain, usually regarded as a natural symbol of fertility and the renewal of life, becomes a symbol of death. High art and the invention of death-bringing rain are the two sides of human intelligence. Her poem should initiate the process of mourning: the raindrops become tears.

Olive Senior's poems deal with the impact of gender, race and class on family life and mothering, but she challenges the view that economic changes are sufficient to promote a change. Prevailing gender ideologies have to be taken into account. Women must develop a voice capable of more than "whispering" and "weeping, weeping". On the one hand, Olive Senior takes a "womanist" stance because she includes men with both criticism and empathy into her depiction of family life. On the other hand, womanism's focus on women's love of self and of community does not come out. The depiction of isolation, loneliness and violence prevails in her perception of the Caribbean family and becomes a call against indifference in human relation. Her poems set out to establish how in black lowclass family the actual status and role performance of women differ from the

\footnotetext{
38 Apollinaire, Guillaume. "Il Pleut". Onevres poetiques. Paris: Bibl.de la Pléiade, 1965. 203.

${ }^{39}$ English Translation in Out of the Kumbla - Caribbean Women and Literature. Eds.Carole Boyce Davies and Elaine Savory Fido, Trenton, N. Y.: Africa World Press, 1990. 34.
} 
stereotype of Caribbean women as being strong, independent, self-reliant matriarchs. The issues of her poems anticipate or reproduce the problems she investigated in her study Working Miracles - Women's Lives in the English-speaking Caribbean (1991). This book is based on the "Women in the Caribbean Project" (WICP), which was undertaken between 1979 and 1982 by a team of scholars - women and men - comprising the fields of anthropology, Caribbean literature, demography, history, sociology and political science. The work was initiated and supported by the Institute of Social and Economic Research of the University of the West Indies. The aim of the book was to examine the Caribbean woman as she performs various roles in her life and to search for an explanation of her sometimes contradictory behaviour, i.e. to appear strong and powerful but weak in her relations with men. The collection of data involved documentary material; semistructured interviews of national samples of 1,600 women in three project territories; detailed life-histories obtained from 38 of the women; in-depth interviews on particular issues related to kinship and friendship networks among women, survival strategies of poor women, life-histories of older women, male perceptions of women, rural women, and successful women in public life. For the first time, Caribbean women from different races, ethnicities and classes were allowed to speak for themselves. The book is divided into four parts that comprise childhood and socialisation, women in their familial and domestic roles, women's economic role performance and their varied sources of livelihood, women in their interaction with the public and political arena and in their relationships with men. Since this project treats many questions of my study, I will summarise some of the results concerning motherhood, family life and socialisation.

The study revealed that Caribbean women have an almost universal impulse for mothering. Nine out of ten women surveyed by the WICP saw childbearing as a fundamental role for women. Children are perceived as an essential part of female identity, and women derive power, status and emotional satisfaction from childrearing. These expectations push girls to prove their womanhood by early childbearing. The first children are usually born to a teenage single mother who is still living at home. Early motherhood, however, prevents these young women from education and vocational training. These young mothers frequently have to migrate from their home village to the towns in search of work which is restricted to menial, low-paying jobs. They leave their children with the grandmothers, other relatives or perfect strangers. The WICP survey showed that less than 50 per cent of first children grow up with their mothers. As a result of migration, the role of the biological mother in the child's life diminished. The decision to leave her child in the care of another person is less guilt-provoking for a mother in a society that understands and supports her behaviour. In Lower-Class Families: the Culture of Poverty in Negro Trinidad (1971), Hyman Rodman suggested:

The mother's mother, mother's sister, and many others may, and frequently do, bring up the child. If there were a strong feeling that the mother should bring up 
her own child, it would be more difficult and guilt-provoking to turn one's child over to another's care. The lack of such feeling makes it possible to maintain the child-shifting pattern, and therefore makes it possible for the woman whose husband has left her to arrange for the care of her child. (Quoted in Senior 1991, 17)

Even though this kind of "child-shifting" mostly results from poverty and necessity, it offers the possibility to look at the question of adoption without provoking guilt in the mother and resentments in the child.

The statistical data also revealed that only one-quarter of the children are born into a nuclear family with mother and father together under one roof. Most of them live in household settings which are largely headed by a woman. The absent father and the powerful, though often exhausted and frustrated, mother are the main characteristics of the Caribbean family. Sometimes fathers disappear totally. More often, a woman has to share her common-law husband with another woman. Fathers maintain visiting relationships with their different families. The tendency to be simultaneously involved with more than one partner is perceived as natural to a man in the Caribbean society. The WICP study informed that "sharing relationships" exist at all levels of the Caribbean society. Sometimes these parallel families are unknown to each other; others might be aware but are ignored. Men are not generally condemned for their infidelity as long as they take a responsible attitude toward the women and children. Women tolerate the situation, even though it often causes bitterness and unhappiness, especially for women who were educated according to European ideals of respectability. The indepth interviews explained women's behaviour. Women spoke about their economic dependency on the father of their children. They also admitted their need for satisfying emotional and sexual relationships. Women who knowingly shared their legal husbands with another woman confessed that they loved him, "of course": "He was loveable, he wasn't ugly like me. He had a nice countenance, he always smiling and you know people love people that smiling. He always have a lot of friends, men also." (Senior 1991, 179) From my own working experience, I know that women who have been beaten by their husbands often end their complaints with the remark: "But he is a good man." It depends on the behaviour of the mothers as to how children experience the situation. An older middle-class woman remembered her mother who came out of a close-knit family: "The relationship was bitter for her. [...] But you sense as a child growing up in the anguish that she had because of this relationship. I mean there weren't many bitter rows. [...], but you sense as a child that something was not right." (Senior 1991, 174)

Another woman described her memories about mother and father in a different way:

He loved women obviously [...] and this is where I blame my mother [...] perhaps she wasn't educated enough to realize that she had no right to get involved with a man with a roaming eye. [...] I admired my father in a sort of secret way. [...] I think 
she admired him too and she loved him. [...] She probably must have loved him.

She treated him good. (Senior 1991, 179)

Olive Senior summarises: 'Women's emotional vulnerability lies precisely in this desire for satisfactory 'relationships' and a susceptibility to male charms, despite everything" (1991, 179).

Since Caribbean society emphasises the superiority of men, the mother only assumes the obligations of the fatherly role but not the dominance that goes with it. The mother is acknowledged and acknowledges herself only as supporting actor. This is due to the influence of white western culture that imported the role model of a subordinate, dependent and self-sacrificing mother. This stereotype contradicts the historical heritage of the Caribbean family system that acknowledged women's autonomy. Senior's study maintains that the discrepancy between the internalised stereotyped role models plus the demands of daily life and the resulting actual behaviour affect self-image and self-confidence in a negative way. The author also argues that the contradictory behaviour of mothers impedes the socialisation process of their children - a process which is complicated by the significance of race and ethnicity and the correlation between race and class in the multicultural Caribbean society. Racial perceptions have been changing through education, growing upward social mobility through economic success, Black Power Movement of the 1970s and increasing recognition of indigenous culture and of African and Indian heritage, but in spite of more open attitudes both skin colour and ethnicity still play an important role for how young people see themselves. On the one hand, the family, especially the mother, is regarded as the main institution for transmitting racial values. On the other hand, mothers have the task of moving the family to higher social status which often implies the adoption of white life styles.

The poems of Una Marson and Louise Bennett dealt with all aspects of this cultural and sociological study. Olive Senior's poems revealed another consequence of changes in the Caribbean society, namely the indifference toward interpersonal relationships. This is also her main concern in the conclusion of her book:

Change might also be having an adverse impact on interpersonal relationships, as a more materialistic culture is eroding the social and friendship networks that were the basis of women's autonomy; [...] Is change having an impact on the socialisation of children and gender-role training and, if so, how? [...] In terms of the female value system, which seems to emphasize social and expressive traits and interpersonal relationships, do 'successful' women retain these values or do they find them impediments which need to be jettisoned in their path upwards? (194)

In her documentation of women's lives in the English-speaking Caribbean, Senior admits that the majority of women are "miracle workers" labouring long hours both inside and outside the house. But she also asks at what prize this is done. Her book takes its title Working Miracles (1991) from a famous poem by our next woman poet. 


\section{Lorna Goodison (*1947)}

"When I came to know my mother many years later, I knew her as the figure who sat at the first Thing I learned to read: 'SINGER', and she breast-fed my brother while she sewed;"

For My Mother ( May I Inherit Half Her Strength )

I Am Becoming My Mother

Songs for My Son

The Woman Speaks to the Man Who Has Employed Her Son

Bibliography and Publications

Lorna Goodison was born in Kingston/Jamaica in 1947 into a family with black and white ancestry. She studied art at the Jamaica School of Art and at the School of the Art Students' League in New York and has worked professionally as an artist, designer, painter and illustrator. Her drawings appeared on all the covers of her books. She has been writing since 1970. She has been writer-in-residence at the University of the West Indies and at Radcliffe College, USA. She now lives and teaches in Toronto.

Her publications of poetry include Tamarind Season (1980), I am Becoming My Mother (1986), which won the Americas section of the Commonwealth Poetry Prize, Heartease (1988), Selected Poems (1992), To Us, All Flowers are Roses (1995), Turn Thanks (1999), Guinea Woman: New and Selected Poems (2000), Travelling Mercies (2001), Controlling the Silver (2004).

\section{Lorna Goodison and her Poetry}

"That's why I think real poetry or the inspiration to write real poetry is a divine thing..."

Family history and human relationship, especially between mothers and children, her concern for the black community, particularly for the hungry and homeless, and the dispossessed shape the themes of her poetry. She combines African traditions with mysticism and a broader religious awareness. Her deep spiritual belief enables her to overcome separation and tension and to reach reconciliation and transcendence. Her language easily slides between Standard English and creole within one poem, often almost seamlessly within one line. She mingles literary allusions with traditional Jamaican speech. She skilfully works with the sounds and rhythm of Standard English in order to render a Jamaican voice. But she also draws a connection between her work as a painter and as a poet. In an interview with Anne Walmsley, she explained that many of her poems develop out of remembered or visualised images. She said recently that she sees herself in "a tradition of praise singers". She is convinced of the divine character of poetry, especially of poetry that is read aloud: 
I think that the way I read now is quite bound up with some kind of internal freedom that is taking place inside of me [...]. I get 'borrowed' as somebody once said. [...] That's why I think real poetry or the inspiration to write real poetry is a divine thing, it is completely out of your hands. You just happen to be standing there and it passes through you. [...] Yes, I think that part of it is luck and part of it is that I'm willing to do the work. You have to work at it because you don't get it so. None of these poems just happen...until maybe twenty drafts later. Every single one of them you have to work forever to make sure you are taking down your 'dictation' properly and when one single word is wrong you have to change it. It's a lot of hard work; it's not as wonderful as it sounds. (Susheila Nasta 2004, 45-57)

The poet has taken on the role of the healer, of poet-priestess. Lorna Goodison performs her poetry in a calm context and recites her poems in an almost tranceinducing manner. She is a writer and singer of hymns, spells, incantations and blessings and, though sensitively aware of tension and disillusionment, aims at creating an atmosphere of peace and harmony.

Representation of Mothering and Children in her Poetry

"My mother loved my father / I write this as an absolute..."

Lorna Goodison is a single mother of a son. In her interview, she said that motherhood transformed her life as nothing else could:

All I can say is that I cannot see my life without mothering a child. [...] I couldn't see myself not doing because to me having a child is the key to a whole lot of things in myself. [...] I remember when I was having my son I used to have these dreams about a little boy saying you have to wake up now. And it's true: he did wake me up! (Susheila Nasta 2004, 56)

Goodison writes about pregnancy, about giving birth and about the relation between mother and daughter. Some poems treat the writing of poems tantamount to a delivery. Her first poem to her mother includes her father and becomes one of the most beautiful poems about love.

Poems

For My Mother (May I Inberit Half Her Strength) $)^{40}$

My mother loved my father

I write this as an absolute

in this my thirtieth year

the year to discard absolutes

he appeared, her fate disguised,

as a sunday player in a cricket match,

${ }^{40}$ Goodison, Lorna. "For My Mother (May I Inherit Half Her Strength)". I am Becoming My Mother.

London/Port of Spain: New Beacon Books, 1986. 46-48. 
he had ridden from a country one hundred miles south of hers.

She tells he dressed the part, visiting dandy, maroon blazer cream serge pants, seam like razor, and the beret and the two-tone shoes.

My father stopped to speak to her sister, till he looked and saw her by the oleander, sure in the kingdom of my blue-eyed grandmother. He never played the cricket match that day.

He wooed her with words and he won her. He had nothing but words to woo her, On a visit to distant Kingston he wrote,

'I stood on the corner of King Street and looked, and not one woman in that town was lovely as you'.

My mother was a child of the petite bourgeoisie studying to be a teacher, she oiled her hands to hold pens.

My father barely knew his father, his mother died young, he was a boy who grew with his granny.

My mother's trousseau came by steamer through the snows of Montreal where her sisters Alberta of the cheekbones and the perennial Rose, combed Jewlit backstreets with Frenchturned names for Doris' wedding things.

Such a wedding Harvey River, Hanover, had never seen Who anywhere had seen a veil fifteen chantilly yards long? and a crepe de chine dress with inlets of silk godettes and a neck-line clasped with jewelled pins!

And on her wedding day she wept. For it was a brazen bride in those days

who smiled.

and her bouquet looked for the world like a sheaf of wheat against the unknown of her belly, a sheaf of wheat backed by maidenhair fern, representing Harvey River

her face was washed by something other than river water.

My father made an assertive move, he took the imported cherub down

from the heights of the cake and dropped it in the soft territory between her breasts ... and she cried. 
When I came to know my mother many years later, I knew her as the figure

who sat at the first thing I learned to read: 'SINGER', and she breast-fed

my brother while she sewed; and she taught us to read while she sewed and

she sat in judgement over all our disputes as she sewed.

She could work miracles, she would make a garment from a square of cloth

in a span that defied time. Or feed twenty people on a stew made from

fallen-from-the-head cabbage leaves and a carrot and a cho-cho and a palmful

of meat.

And she rose early and sent us clean into the world and she went to bed in

the dark, for my father came in always last.

There is a place somewhere where my mother never took the younger ones

a country where my father with the always smile

my father whom all women loved, who had the perpetual quality of wonder

given only to a child...hurt his bride.

Even at his death there was this 'Friend' who stood at her side, but my mother is adamant that that has no place in the memory of my father.

When he died, she sewed dark dresses for the women among us and she summoned that walk, straight-backed, that she gave to us and buried him dry-eyed.

Just that morning, weeks after she stood delivering bananas from their skin singing in that flat hill country voice

she fell down a note to the realisation that she did not have to be brave, just this once and she cried.

For her hands grown coarse with raising nine children

for her body for twenty years permanently fat

for the time she pawned her machine for my sister's

Senior Cambridge fees

and for the pain she bore with the eyes of a queen

and she cried also because she loved him.

Analysing Goodison's long narrative poem for her mother, I will take into consideration and partly contradict the thoughts of three literary critics. As already men- 
tioned, Olive Senior takes two short passages of the poem to accompany her study. This part is taken as an epigraph: "She could work miracles, she would make a garment from a square of cloth in a span that defied time." Senior comments:

Lorna Goodison's poem 'My Mother' is quoted as the epigraph to this book because it describes so graphically a familiar Caribbean role model: the woman as miracle worker, an adept at making something from nothing. [...] 'Making do' expresses a social phenomenon which is widely accepted: that it is a fundamental role of poor women to make do with what they have or, better still, 'make something from nothing' in order to maintain their families. [...] In some cases, 'making do' represents personal denial and sacrifice. (1991, 129-130)

Senior also includes the following part of the poem: "I knew her as the figure who sat at the first thing I learned to read: 'SINGER' and she breast-fed my brother while she sewed; and she taught us to read while she sewed and she sat in judgement over all our disputes as she sewed" (191, 9-10). Senior comments:

Because of all the demands on her time and attention, the working mother might not in fact be able to devote much of her time to the raising of her children. [...] Home-based activities - making handicrafts or preserves for sale, cooking, laundering for others, sewing - also afford the mothers a means of combining child-care with income-earning activities. (1991, 9-10)

Olive Senior does not continue to juxtapose the poem to other parts of the study. Since she only regards motherly work, the poem seems to be an unrestricted celebration of this aspect. Critics have frequently overlooked that main parts of the poem deal with the relationship between the mother and the father and the resulting tensions which affected the family life and the children. In "Textures of Third World Reality in the Poetry of Four African Caribbean Women" (1990), Elaine Savory Fido interprets Goodison's poem as following:

The opening lines of this poem declare an awareness of contradictions. But the poem becomes very cosy and proceeds to present the portrait of the mother, full of the enchantment of myths, as all of our images of our mothers tend to be. Goodison's image of the emotional texture of her mother's life is honest and emotionally appealing (Carole Boyce Davies and Elaine Savory Fido 1990, 37-38)

Senior and Fido do not pay attention to the fact that Goodison dedicates equal parts of the poem to her mother and her father. This long poem narrates the time of engagement, the wedding party and the matrimony of her parents. It is one of the rare poems about the dynamics of family life. The third critic, E. A. Markham shortly remarks: "Goodison celebrates her mother ('For My Mother...') in a poem of sensuality; of pain and hope betrayed; of the maturity of acceptance" (1989, 34). I agree with this summary by a male voice and will base and expand my analysis on it. 
This poem begins with an epiphany. At the age of thirty, the speaker of the poem observes her mother crying for the first time. This happens on a morning several weeks after she had buried the father dry-eyed. This unexpected action shows her that her mother had loved the father. This moment of revelation liberates the poet's voice. The poem starts with short and almost breathless sentences and matter-of-fact statements and grows to a long narrative poem with long lines and long units of breath. It develops a language full of imagery that appeals to any of our senses, such as sight, sound, touch, taste and smell. The long lines and enumeration of events work with biblical rhetoric and celebrate a plenty of human experience, of joys and pains. Places of origin and belonging and dresses are used as recurring images and symbols to structure the poem.

The poem narrates the engagement, wedding and marriage of the speaker's parents until the father's death. It begins as the story of a mésalliance. The father comes "from a country one hundred miles south" of that of the mother. He fits all stereotypes connected with the "south": he is black, "a Sunday player in a cricket match", "dandy", "vain", "elegantly dressed", "wooing with words". Although he was almost an orphan ("he barely knew his father, his mother died young"), he was probably the only one who experienced human warmth during his childhood. He "grew up with his granny", who is the only relative called by a pet name. During the marriage, the father has "a place somewhere", "a country where he hurt his bride". This place has by the decision of the mother "no place in the memory". The mother, however, comes from areas that have their own legislator and appointed government. The first time, the father saw her, she "was sure in the kingdom of my blue-eyed grandmother". She "was a child of the petite bourgeoisie" whom the father had conquered. "He took the imported cherub down from the heights of the cake and dropped it into the soft territory between her breasts." He openly demonstrated his conquest on the wedding day with this confidently aggressive and self-assured gesture. This playful and imaginative exhibition of sensuality and sexuality must have been a slap in the face of the bourgeois wedding society. It must have been a provocation for the "royal" grandmother who was probably forced to agree to this mésalliance because of a pregnancy before marriage. The grandmother's kingdom made a show of queenly wedding dress and a bouquet that "looked for the world like a sheaf of wheat against the unknown of her belly, a sheaf of wheat backed by maidenhair fern." Splendour and pomp shall "pull shame out of her eyes" says the poet in another poem.

Lorna Goodison works twice with empty spaces in her poem. The rare use makes it still more resonate with meaning. These pauses connect the significant events and experiences. After the father's assertive move of the cherub..."she cried." Later, during the marriage "there was a place somewhere where the father hurt ...his bride." The father "with the always smile [...] whom all women loved, who had the perpetual quality of wonder given only to a child" hurt a woman who 
remained restricted in her bridal expectations of life. Imprisoned in her rigid thoughts of respectability, she could not overcome and accept the infidelity of her husband. Probably, she became a figure of constant reproach for her husband since she had given up the dreams of her youth to become a teacher. She had lost the smooth skin of her hands and her slender body because of her work and her many pregnancies. But "she bore the pain with the eyes of a queen". Certainly, she became a figure of self-discipline and self-sacrifice for her children. She wanted her children to climb up the social ladder she had fallen down with her marriage. She did hundred things at once: "she breast-fed a child, while she taught her children to read, while she sat in judgement over all their disputes and while she sewed." It is only right and proper that the main events of life are connected with the results of her incessant activity of sewing. The first encounter between father and mother, the wedding day and the father's funeral are remembered with the clothes worn on these days. The mother was a figure of fear and awe for her children who sat at "Singer", a sewing machine. She certainly taught her children to read the word "SINGER", but probably she never sang with them. The moment when the mother reaches the "maturity of acceptance" - to use the words of the critic - is the moment of liberation for both mother and daughter. Without the revelation of love between mother and father, deception, resentment and bitterness would have prevailed. Now the daughter can openly express her love for both, mother and father, and narrate the dynamics of family life in the biblical rhetoric of a praise song. As a child, she had learned from her mother's work as a seamstress to read the word "SINGER". The heritage of father and mother enables her to become a singer. This poem, which is openly dedicated to her mother, uses suitably the heritage of the father who is "wooing with words". The next poem, written in a minimalist manner, properly bears the stamp of the mother.

I Am Becoming My Mother ${ }^{41}$

Yellow / brown woman

fingers smelling always of onions

My mother raises rare blooms

and waters them with tea

her birth waters sang like rivers

my mother is now me

My mother had a linen dress

the colour of the sky

and stored lace and damask

tablecloths

to pull shame out of her eye.

\footnotetext{
${ }^{41}$ Goodison, Lorna. "I am Becoming My Mother". I am Becoming My Mother. London/Port of Spain:
} New Beacon Books, 1986. 38. 
I am becoming my mother

brown / yellow woman

fingers smelling always of onions.

This poem celebrates the intimate relation between mother and daughter not only in its content but also in its poetic form. The poem consists of four stanzas. If the title is included in the first stanza, the first and last stanzas are almost identical differing only in the direction from "yellow / brown woman" to "brown / yellow woman". The speaker identifies herself with the colour and smell of her mother's skin: she slips into her mother's skin. These stanzas form a circle around two stanzas of four lines that praise the life-giving power and creativity of the mother and also her inclination toward beauty and wealth plus her subordination to convention (she "had a linen dress the colour of the sky", she "stored lace and tablecloths to pull shame out of her eye"). It mentions both qualities and small vices. The poem invokes the intimacy between mother and daughter and the community of black women in the tradition of Alice Walker's essay "In Search of Our Mothers' Gardens." The rhymes ("tea / me", "sky / eye") and the rhythm of the middle part sound like a counting-out rhyme - similar to "eeny meeny miney mo". This oral form of poetry can be recognised even by people from different cultures, but with its fourteen lines consisting of a sextet and an octet, the poem resembles the sonnet form as well, the preferred European form for love poetry. Since the movement starts and ends at the same point, the poem gives the impression of a playful interaction between mother and daughter and a complete transformation and identification. This relationship between mother and daughter seems so easy in comparison to the thoughts of many feminists on this subject. Difficult mother-daughter-relations seem to prevail in psychoanalysis and literature.

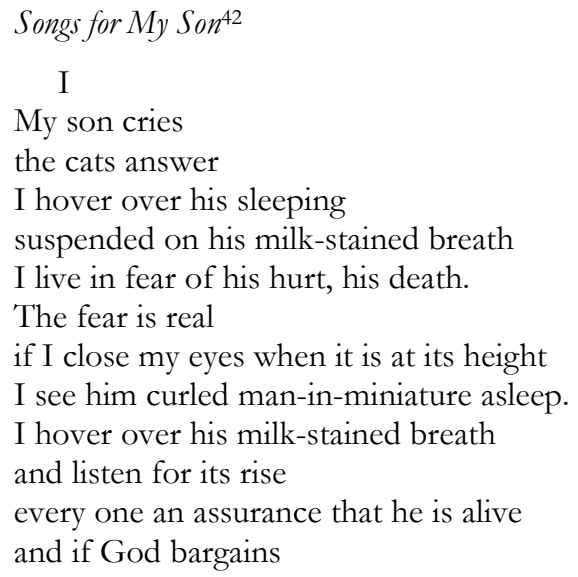

${ }^{42}$ Goodison, Lorna. "Songs for My Son”. I am Becoming My Mother. London/Port of Spain: New Beacon Books, 1986. 17-18. 
I strike a deal with him

for his life I owe you something, anything but please let no harm come to him.

The cat cries my son answers his sleep is short his stomach hurts.

\section{II}

They gather from beyond

Through the trees they come gather on the banks of the family river one by one they raise the keening song great grandmother Rebecca of the healing hands Tata Edward, Bucky, and Brownman my father's lost mother Maria and now my father come to sing the birthsong and Hannah horsewoman to ride me through. It's a son, a great grand grandson, a man born to a headstrong, heartfoolish woman, part the birth waters with river-washed hands and let the newson through, woman born of strong-limbed woman woman born to parents in peacetime behold your son

flesh of your flesh your life's work begun.

\section{III}

The mid-wife tie-head African woman fingers like healing-roots feeds me thyme-tea to hurry on your coming summons the appropriate spirits to witness your crowning, a knife keen with garlic to sever you from me and we'll never smell its primal top-notes you or I without memories of our joining.

\section{IV}

I'll name you Miles I say

for the music, and for coming

a long way

you suck, my womb pulls 
the thirst constant

the connection three-way.

In her interview, Lorna Goodison spoke about the personal change she experienced through the birth of her son. He has not only changed her daily routine because he awakens her in the morning but he has also changed her attitude towards life as well. The poem "Songs for My Son" sings about the birth and the first months of her son's life in four stanzas of two times nineteen, twelve and six lines. The rhythmical structure works with repetition: in the first and second song, the main stories are told in ten lines and surrounded by nine lines that deal with either natural sounds or a praise song. The third song appeals to all our senses except sound, but it consists of twelve lines similar to the twelve-tact-scheme of jazz. The last song, comprising six lines, alludes directly to music and the famous jazz musician after whom Lorna Goodison's son is named. In these songs, alliteration and all sorts of rhymes - full, half, inner eye rhyme - create the poetic voice. The poem does not have a chronological order but begins with the intelligible anguish of the present. After the birth of a child, the mother feels the pain of separation. She is always alert like an animal to protect her child against perils lurking everywhere, even in her dreams at night. She promises God everything for the protection of her child. In the first stanza, the mother experiences the cries of cat and son and her awakening as a relief from a nightmare. A conversation between son, cats and mother brings human beings and animals together and indicates their intimacy and their closeness. The song is composed of natural sounds: the crying of son, mother and the cats and the breathing of the son. The second stanza is a song of praise that celebrates the birth of a child as a festivity for the extended family. The gathering of the family includes the living and the dead members of the family alluding to African tradition and culminates in a jubilant song of mother and son. The third stanza recalls the delivery with the help of an African midwife who uses herbal medicine and African spirits to guide and to protect the labouring woman and the child. She cuts the umbilical chord with a knife "keen with garlic" and sets an everlasting scent mark. Scents conjure up our memories in a precise way. For the mother it is a way to deal with the pain of separation. In the last stanza, the mother has found consolation in the memories told in the preceding stanzas. Nurturing her son, she has overcome the separation. She alludes to the hormonal situation of the maternal body. The sucking child controls the production of milk and the contraction of the womb. Mother and child still live in symbiosis and depend on each other. In the development of the poem, the significance of music increases. The poem builds a finely patterned tune of sounds and rhythms from natural sounds to an African hymn to the sophisticated art of contemporary jazz. In "Songs for My Son", Lorna Goodison depicts, sings and celebrates the universal biological facts of mothering: giving birth and nurturing a child. 
The literary critic Elaine Savory Fido regards Lorna Goodison as one of the most accomplished Caribbean poets. She appreciates her human warmth, her sensuality and her humour. She agrees that this poetry gives comfort and security, but she criticises the poet for not taking the terrible conflicts of the Caribbean society seriously and her tendency to resolve tensions in harmony and peace. I do not agree with this judgement. On the one hand, this is not an easy reconciliation. The poem "For My Mother (May I Inherit Half Her Strength)" indicates already in the title that this is not an unrestricted celebration. The term "strength" suggests greatness, pungency, vigour. Wishing for herself only half of her mother's main feature, strength, the poet expresses her resolution to leave the other half open for another heritage - for the paternal contribution. A close analysis of the poem reveals the depiction of tensions and deprivation under the surface of rigid discipline and duty within a family subjected to the differences of race ("shadism") and class. Goodison does not aim to come to a unity or reconciliation at any price, but to a "maturity of acceptance" - that indicates an advanced step of personal development. The lyrical and musical qualities of her voice seem to be so seductive that the reader and listener is unaware of the underlying tensions. On the other hand, critical response to poetry depends on theoretical standards. Feminist and post-colonial criticisms demand a social and political engagement from art. In this context art is rather calculated to resist than to reconcile, to dwell on conflict rather than on peace. But is it necessary to insist always on these conceptions? In my concluding commentaries, I will return to these questions. Our next poet belongs to a younger generation and developed a totally different music and voice.

\section{Jean 'Binta' Breeze $(* 1956)$}

"sing girl sing dere's more to you dan skin"

Birthing

Atlantic Drift

For Big Mammy

Moonwise - (for my children, all)

Testament

Mother...Sister...Daughter...

Biography and Publications

Born in 1956, Jean 'Binta' Breeze was brought up by her grandparents who were peasant farmers in rural Jamaica. She grew up in Patty Hill, a small village in the hills of Hanover. She began writing poetry in the 1970s. In 1978, she moved to Kingston to study at the Jamaica School of Drama where she met the dub poets Oku Onuora and Michael Smith. She first performed on stage with the dub poet Mutabaruka. She established herself soon as writer, performer and recording artist. 
In 1985, the Jamaican-born British dub poet Linton Kwesi Johnson introduced her to an European audience. Since then, she has lived in London but spends half of the year in Hanover to be with her three children. Today she is recognised as one of the most influential performance poets. She has performed her work throughout the world. Being an actress, dancer, musician, choreographer and theatrical director, she is famous for her powerful presence on stage. Photographs show her as a small fragile woman with soft features and big eyes. She has been a scriptwriter for theatre, television and film and a member of the editorial board of Critical Quaterly. Now she is mainly working as a performance poet and lecturer of creative writing, performance and theatre studies.

Her collections of poetry include the books Ryddim Ravings (1988), Spring Cleaning (1992), On the Edge of an Island (1997), Song Lines (1997), The Arrival of Brighteye and Other Poems (2000). Several recordings of her work are available.

Jean 'Binta' Breeze and her Poetry

"My politics were shaped by my personal experiences and those of the people round me in their day-to-day concerns. The closest concerns I shared were obviously those of women."

Dub poetry originated from a fusion of the spoken word and reggae music in Jamaica and the Caribbean diaspora of London in the 1970s. In the 1960s, the popular music of the Caribbean spread all over the world. Musicians in the studios of Kingston created reggae from the older Jamaican music of ska and mento. Originally, dub is the drum and bass track of a reggae number to which additional rhythms, other melodies or words are dubbed in. Poets began to compose poems to be performed with music in order to reach a wide audience. The most accomplished dub poets manipulate sound pattern and translate the rhythm of reggae into speech pattern.

In those post-Independence days, disillusionment about betrayed hope and expectations caused the militant atmosphere and politics of the 1970s. The message of Caribbean popular music was political, a protest against poverty, exploitation and discrimination. The language was strongly influenced by Rastafarianism and the vocabulary of an ascendant black power movement on both sides of the Atlantic. Rastafarianism originated from the crowning of Haile Selassie in 1930 and developed into a world-wide back-to-Africa movement that celebrated African heritage and employed Biblical speech. In the Caribbean, religious music and protest songs often go together. The most famous representative was Bob Marley whose person and songs gained cult status.

Jean 'Binta' Breeze has stretched the dub form in different directions. She began to experiment with different musical styles including jazz, blues and gospel in her work. She reflected on the form of language and poetry in a kind of "metadub". She is writing in both Standard English and Creole. She deals with everyday experience and complex political issues like the Third World debt to the World 
Bank and the IMF. Breeze is a pioneer for women's dub poetry. In her newspaper article "Can a Dub Poet be a Woman?" (1990), she wrote an answer to a magazine that had called her "the first female dub poet in a male-dominated field". She defended her position to introduce a woman's voice and body into this highly gendered genre. She mentioned three comments on her work that made her aware of the "difference it actually made being a woman in the field". First, her political poems "seemed to suggest that it was much more masculine to achieve such distance from the subjective or personal". Second, she "was told by many people that a radical dub poet should not be 'wining up her waist' on the stage as it presented a sexual image rather than a radical one." Third:

[...], when I had my first album turned down by the American company that had put out my previous work, on the grounds that my new work was becoming far too personal and there were too many pieces dealing with love. [...] My politics were shaped by my personal experiences and those of the people round me in their day-to-day concerns. The closest concerns I shared were obviously those of women. I lost the need to teach or preach, especially to audiences already converted, and found the courage to tell, and I will not manipulate the voices that work through me or the truth they bring. (Breeze in Donnell/Welsh 1996, 498 $500)$

\section{Representation of Mothering and Children in her Poetry}

Jean 'Binta' Breeze is a single mother of three children, one son and two daughters, who live in Jamaica. In an interview with Jenny Shape in 2003, she said: "The necessity for me to be in England is purely economic." Breeze resists the concept of a post-colonial black victim identity for women. She avoids the depiction of conflict and violence and directs our attention to the psychological dimensions of women's experience. Breeze is a wonderful storyteller of childhood memories in Kingston, of family life and of the work of mothers at home. Her poems deal with the biological, social, cultural and historical aspects of mothering and, especially, the experience of mothering in the Caribbean diaspora in London.

\section{Poems}

$$
\begin{aligned}
& \text { Birtbing }{ }^{43} \\
& \text { ah carry she cross water } \\
& \text { ah carry she cross lan } \\
& \text { ah carry she } \\
& \text { wid all dignity } \\
& \text { ah born she on a day } \\
& \text { like balm } \\
& \text { a day of potency }
\end{aligned}
$$

\footnotetext{
${ }^{43}$ Breeze, Jean ,Binta' “Birthing”. Spring Cleaning. London: Virago Press, 1992. 55.
} 


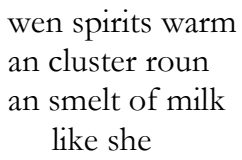

This poem appeals to all our senses: ears, eyes, touch and scent, and it challenges our imagination. It combines Christianity and African myth to praise birthing. It conjures up a solemn heavenly atmosphere with the sound of a gospel song and an earthly moment with the warmth and the magic of an African incantation. The rhymes invest the woman giving birth and the newborn daughter ("she") with "dignity" and "potency". The biblical expression "balm" is echoed in the "smelt of milk" of the African spell in order to connect both Christianity and the African heritage and to welcome the child in the black community.

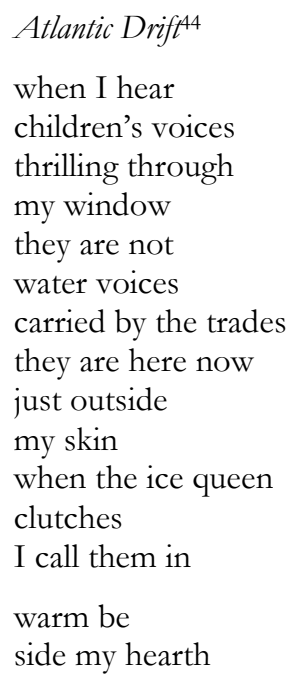

This seems to be a poem for a speaking voice with a long unit of breath. But the analysis of the poem reveals that the message depends on how we read the lines. We detect the wordplay between "skin" and "ice queen" and the break between "warm be / side my hearth" only with our eyes. Then the poem appears like the beginning of a letter. It alludes to the poet's personal situation: staying in London by herself, she is separated from her children who are living in Jamaica. Voices of nearby children are "thrilling" and remind her of her distant children. The poem's title creates and enhances the distance together with the passive voice of the image of "water voices carried by the trades". Nostalgia and wishful yearning emerge "they are here now just outside my skin". The fairy tale figure of the ice queen refers both to Britain's bad weather and the chill of separation and loneliness.

${ }^{44}$ Breeze, Jean 'Binta'. "Atlantic Drift”. Spring Cleaning. London: Virago Press, 1992. 37. 
"Warm be / side my hearth" could be read as a wish for the children and an imperative mood for the speaker of the poem to overcome this blue moment. Title, imagery and display of this poem constitute a personal voice ("I") and a universal statement about the situation and the emotions of mothers who are forced to live without their children.

For Big Mammy ${ }^{45}$

tonight is much talking

Big mammy died

Man Jack is calling at the door

last week

i saw ash

and dreamt nearly

of weddings

man jack is calling

Nurse!

Nurse!

Tebo is back

from medical school

he was so young

so gangly

on the football field

tomorrow he will

sign

for old ones

who raised him

Son

we are glad you are here

tonight

is much talking

sisters are in the bedroom

plaiting hair

by the light of lamp

home sweet home

Big Mammy

remember when

in your socks

you came out your

back door

to the soft earth

and the solid roots

of the bread

45 Breeze, Jean ,Binta’. “For Big Mammy”. Spring Cleaning. London Virago Press, 1992. 46-47. 


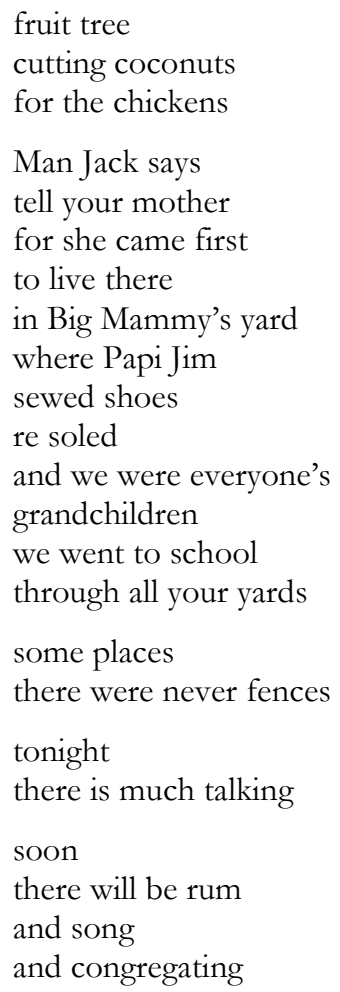

This poem tells the story of an evening and a night when the extended black family and all their neighbours come together to prepare the funeral of Big Mammy, "For Big Mammy tonight is much talking". The poem is divided into two parts of equal length interspersed with repetitions of the refrain "tonight there is much talking". The first part recalls the sudden death of Big Mammy and tells about the members of the family who are around. The son is back from medical school and the sisters are plaiting hair in Big Mammy's "sweet sweet home". The second part reminds the family of Big Mammy's domestic activities. This part brims with oand a-sounds of admiration and awe ("home", "socks", "door", "solid", "cutting", "coconut"). Big Mammy was the centre of her yard and created the feeling of togetherness and belonging, "we were everyone's / grandchildren / we went to school / through all your yards". Two short comments indicate the changes that occurred in the family and in the black community. "Son / we are glad you are here" shows that Tebo usually is absent. "Some places / there were never fences" indicates that there are fences and exclusion now. Family and neighbours gain a short moment of the former intimacy and closeness before the official part of the funeral. The poem expresses a nostalgic yearning for good times gone. It praises mothering as the domestic part of women's lives and its significance for the black community. 
Moonwise (for my children, all) ${ }^{46}$

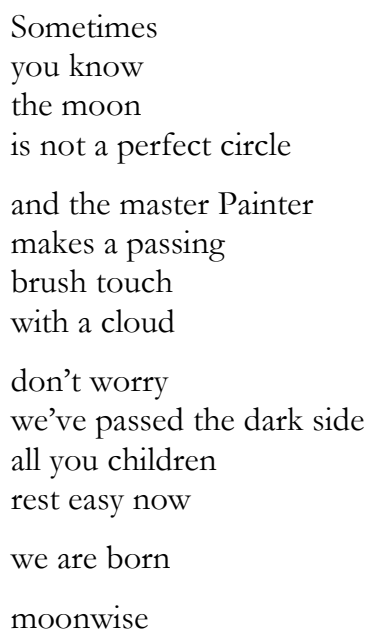

The poet as mother expresses her love for her children and gives advice in the poetic form of a sonnet. She tells her children about the Ups and Downs of life and compares them to the moon's appearance on the sky. Describing these dark sides of life as "a passing brush touch" of "the master Painter", the poet regards them as transitory and as only attached to the surface. They cannot affect her core confidence in life. The really "dark side" lies behind. Black people have passed, have overcome slavery and colonisation in the past. The poet as mother uses biblical imagery and connects human life with the universe and the history of her people to console, to admonish and to encourage both her own children and the community of black people. The subtitle underlines the message "for my children, all".

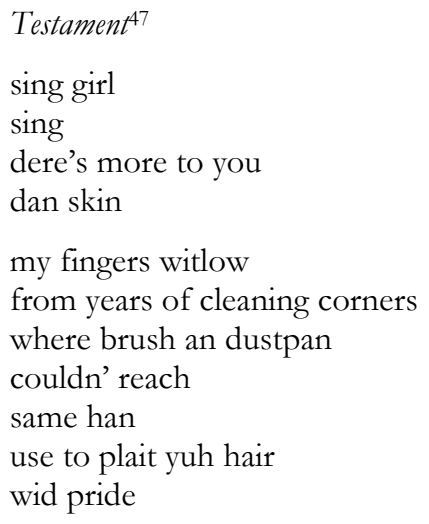

\footnotetext{
46 Breeze, Jean 'Binta'. "Moonwise”. Spring Cleaning. London: Virago Press, 1992. 56.

${ }^{47}$ Breeze, Jean ,Binta'. “Testament”. Spring Cleaning. London: Virago Press, 1992. 7-11.
} 
oil it thickness

wid hope an dreams

tie it up wid ribbons

of some rainbow future

mi apron was a canvas

all de greases

from rubbin down all yuh bodies

an cooking plenty greens

ah use to smell it

before ah roll it up

tek it to de laundry

smell de action a mi days

de sweat a mi action

mekking likkle time

fi yuh all

an yuh fadda

meeking time

fi a likkle formal prayer

to de heavens

fah dese days ah fine

every thought is a prayer

dat de pot won't bwoil over

while ah pull myself upstairs

to scrub de bath

dat de cooker

won't start play up

an de smell a gas

come leaking troo

dat someting teacha sey

would register

an yuh all could see a way

to stretch yuh brain

an move yuh han

pas idleness

to de honour a yuh work

ah can feel it

now yuh gettin older

steppin pas my likkle learning

dat yuh tink ah stupid

ah see how yuh fadda

embarrass yuh frens

wid im smell a oil

from de London trains

so yuh now stop bringing dem home 
ah don't talk to yuh much no more

outside de house

ah never did have time

to soun de soun

a de madda tongue

or mek mi way wid ease

troo dem drawing room

but in you goings girl

don't mind we smell

we memories of back home

we regular Sunday church

in de back a de local hall

we is jus wat we is

watching you grow

into dis place

an ah want yuh to know

dis is yuh own

we done bleed fi it

yuh born here

in de shadow a Big Ben

im strike one

as de waters break

an yuh come rushing troo

ah do't move far as yuh

is not mi duty to

an de cole does bad tings

to mi knee

I is ole tree girl

rough outside

wid years of breaking bark

feeling de damp

yuh is seed

burstin new groun

so sing girl

sing

dere's more to you

dan skin

ah see yuh eye turn weh

anytime yuh see mi han

an at my age

ah really kean worry

who ah belch in front a

an if ah see someting good

in a skip

ah know it embarrass yuh 
wen ah tek it out

but in dis place

dem trow weh nuff good tings

an waste is something

drill out me

from young

we had to save weself

from a shoestring

to a likkle lef over

an yuh know

how ah keep all yuh tongue sweet

wen ah tun mi han

to mek something special

out a nutten

ah nat trying to mek yuh feel sorry

believe me

ah just want yuh to understand

dat we come as far as we can

an we try to arm yuh

wid allde tings

dat in fi we small way

we could see dat yuh might need

ah nat telling yuh look roun

jus

sing girl sing

dere's more to you

dan skin

yuh granmadda

was Nana

mountain strong

fighting pon er piece a lan

she plant er corn

one one

two two

a likkle pool a dirt

between hard cockpit stone

reap big ears

er grata was sharp

use to talk dry corn

to flour

needed for de trail

de long hard yourney

carving out somewhere

jus like we come here 


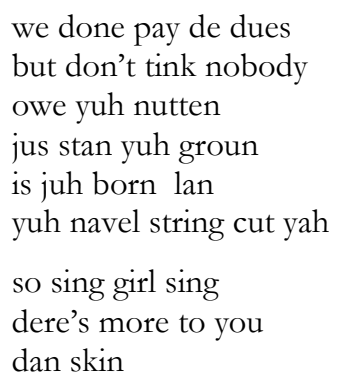

This poem is the testimony of a black Caribbean mother who raised her children in the diaspora of Britain. It is written in a Creole that can easily be decoded. The poem contains eleven stanzas of different length comprising six to twenty-two lines. They are interspersed with the slightly varied refrain "sing girl sing / dere's more to you / dan skin". The refrain is repeated four times and divides the poem into three parts. These sections correspond to the three generations of daughter, mother and grandmother.

In the first section, the mother sets the frame and gives a reason for the time of her testimony. She is getting older, "my fingers witlow" and "de cole does bad tings to mi knee". But with the biblical reference, "I is ole tree / rough outside / wid years of breaking bark", she transcends the mere personal. Then she recalls the deep intimacy between mothers and children in early childhood, the closeness of the bodies, her caring and nuturing activities, "plaiting the hair", "rubbing and smelling the bodies", "cooking plenty greens", in the privacy of the black family. She mentions both her assiduousness and the father's industry. Both parents invest in a better future for their children. But at the time of adolescence, the differences in race and class interfere and disturb the relation between parents and children. Throughout, the poem addresses motherhood, race and the identity of both mother and child. In successive steps, the poem and especially the refrain, describe race as a matter of cultural and social perception, not of biology and skin, "Sing girl sing dere's more to you dan skin."

Black children discover difficulties in interracial friendship during puberty. Sorting is a painful experience in these years. The mother senses that the children begin to feel shame for their family background, "ah can feel it / dat yuh tink ah stupid", "ah see how yuh fadda / embarrass yuh frens / wid a smell a oil / from de London trains / so yuh now stop bringing dem home." But she stakes a claims against these feelings of inferiority at least for her children. They are entitled to be included into this society as citizens with all rights and duties, "an ah want you to know / dis is you own / we done bleed fi it / you born here / in de shadow of a Big Ben / im strike one", "yuh is seed / burstin new groun". After this information, the refrain follows as a self-confident instruction to her daughter and takes a historical line of saying, "this is the consequence of our personal fate": "so sing girl / sing / dere's more to you / dan skin." But the mother herself has lost her 
security under her daughter's silent critique. There is the touching passage when the mother ruminates, "ah see yuh eye turn weh / anytime yuh see mi han / an at my age / ah really kean worry / who ah belch in front of." Facing the silent reproaches of her child, who adopted white norms of behaviour, the mother lost her carelessness and her confidence in black norms of etiquette. She has become a stranger in her own family who does not know how to behave. Race and racism are depicted in this tiny detail and are shown to have real effects on the life of a black family. The mother acknowledges that her daughter wants to adjust to white norms in order to be accepted in the white society. Moving between past and present time, the poem suggests that identity is created in reaction to the perceptions and prejudices of others. For the future, however, the mother develops her vision of an identity that is made by the person herself and based on racial pride. She goes on to talk about her experience of mothering under the burden of poverty in a materialist society. She restores her pride and her dignity through her work and her achievements, "an yuh know / how ah keep all yuh tongue sweet / wen ah tun mi han / to mek something special / out a nutten." Even now she is far from regarding herself as a self-sacrificing woman, "ah nat trying to mek yuh feel sorry / believe me / ah just want yuh to understan / dat we come as far as we can / an we try to arm yuh / wid all de tings / an nat telling yuh look roun / jus..." Here the refrain appears for a second time. Now it reminds the daughter that she has a wonderful heritage and a powerful resource in her mother's life as model. This message leads to the third section that extends mothering to the ancestral mothers, the mythical Maroon Nana, who was an eighteenth-century African Jamaican fugitive slave woman and became the symbol of Jamaica's resistance to slavery and colonisation. In the end, the mother compares her journey and her life to Nana's fight. They have both been "fighting pon er piece a lan". Now she claims the right of citizenship for the whole family, "we done pay de dues / but don't tink nobody / owe yuh nutten / jus stan yuh groun / is yuh born lan / yuh navel string cut yah." The final refrain repeats the historical line in a long breath saying that this is a consequence of the fate of black woman through long times: "so sing girl sing / dere's more to you / dan skin."

This poem conveys a changing awareness of mothering under the impact of racism and class plus economic constraints. It considers the joys and pains of care-giving on many levels - biological, social and historical. It explores how problems of racial and cultural separatism build barriers within the family. Finally an old mother has been given a voice to tell how differences of race, class and economic status interfere into the mother-daughter relationship. The mother has to pay with self-denial for the privileges of her daughter. She does it without resentment because she loves her children. The poem shows how the mother questions her understanding of race and culture through her experience of mothering in the diaspora. White mothers of black children have been writing in a similar way about the difficulties of mothering in a multi-racial world. Then the poem 
moves beyond the confines of the nuclear family and extends to the matrilineal diaspora. At the same time, it links the historical Caribbean with the western world, so this poem constitutes a highly personal and intimate testimony of mothering and a universal ethical and political message. The example of this black mother shows mothering as selfless love that cannot be changed by political, social and cultural difference. This black mother regains her pride and her selfesteem through her mothering and develops a confident voice so that she is capable of dealing with racism and colonialism. She endows her daughter with racial and cultural confidence. Racial identity is regarded as an achievement that can fill a black person with joy and pride. It justifies the refrain so that the child can sing, "so sing girl sing / dere's more to you / dan skin." The refrain is repeated at the turning points of this process of identity-formation. As a song, it takes the audience in. The mother as speaking voice and the poet as performer are taking the initiative and are singing the song in which the audience participates.

As another form of women's bonding, the Caribbean poet Jane King has dedicated her poem "Intercity Dub" to Jean 'Binta' Breeze. This poem describes the violence and the problems of racial and cultural barriers in the British diaspora and celebrates Breeze's creativity and her singing as healing acts. The poem imitates the rhythm of the train. Since this poem effectively brings the performance to eye and ear, it is a fine companion of the written text. The quotation of some passages will give an impression:

Intercity Dub, For Jean ( for Jean Binta Breeze) ${ }^{48}$

Brixton groans -

From the horror of the hard weight

Of history

Where the whites flagellate

In their ancestry

And the black hold the stone

And they press it to their hearts

And London is a hell

In many many parts.

But your voice rings true

From the edge of hell

Cause the music is the love

And you sing it so well.

[...]

There's a factory blowing smoke-rings

Cross the railway line

You know it took me time to learn

That this country wasn't mine

\footnotetext{
48 King, Jane. "Intercity Dub, For Jean (for Jean Binta Breeze)". The Routledge Reader in Caribbean Literature. Eds. Alison Donnell and Sarah Lawson Welsh. London and New York: Routledge, 1996. 385-387.
} 
And I want to go back home

To swim in the sunset bay

Feel the water and the light

Soft-linking night and day

Like the music make a bridge -

But there's joy here too

And I might not have seen it

If I hadn't heard you.

[...]

The Brixton-battered sisters

Hissed their bitterness and hate

With their black man the oppressor

And death the white race fate

And they don't want to build

No bridge no gate -

And I nearly turned away

In pain and rage and fear

Till I heard your voice

Ringing clarion-clear

And you burst like a flower

From the sad sad soil

And you blew like a breeze

Round the shut-tight hall

And you danced like a leaf

And you sang like a bell -

You said Music reaches heaven

And music changes hell

Cause the music is love

And you sing it so well.

Breeze's dub poetry contradicts those critics who regard the texts of performance poetry as trivial and conventional, but only a close analysis reveals the subtlety of her texts. The meaning is not pushed into the text by the performer alone. Certainly, her poems wake up the audience through her performance, and Jane King's poem demonstrates how the performance takes the audience in. Jane King praises Jean 'Binta' Breeze's power of reconciliation and consolation, but in the next poem, the poet confronts her audience with social and political conflict.

Mother... Sister... Daughter... ${ }^{49}$

'If you should see me,

walking down the street,

mouth muffled

head low against the wind,

${ }^{49}$ Breeze, Jean ,Binta'. "Mother... Sister... Daughter...”. Spring Cleaning. London: Virago Press, 1992. 74. 


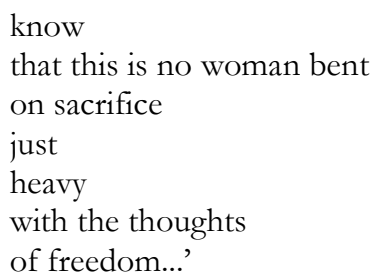

Here Jean 'Binta' Breeze moves from creole to a highly sophisticated and unusual construction of a sentence in Standard English. This poem is a written instruction that consists of one conditional sentence. The condition is introduced by "if and should". This combination indicates that the action described, though possible, is not very likely. So we will probably not see the speaker of the poem "walking down the street, / mouth muffled / head low against the wind." In the case of an exception, we are instructed to regard her as a woman "heavy / with the thoughts / of freedom...." even though she might give the impression of "a woman / bent on sacrifice". The difference is just not discernible since both have the same appearance. This poem calls for women to be active and to develop a public voice. This is still a needed and ongoing instruction from mother to sister to daughter and to the next generation as the dots indicate. This poem conveys the poet's political conviction which is described in the following interview with Henry Palmer:

According to Jean Breeze, clichéd media images and jargon help perpetuate the myth that the Third World is a helpless case. Charity, she says with rising anger, is just a smoke- screen. [...] Dub poetry has been criticized for being too political. But Breeze shrugs off the criticism, noting that her art is rooted firmly in social and political conflict. She is worried by the stereotype that Third World writers and thinkers are mired in the past and that the full range of art and social comment from the South goes unnoticed. 'There is this suggestion that we all are trying to deal with our colonial heritage, instead of actually being at the forefront of what is happening in the world today.' [...] And if you look at the work of Breeze herself it's clear that her vision extends way beyond of herself as a post-colonial subject. [...] Breeze considers these meditations on her island culture a kind of personal communion. 'They come from my healing side,' she says. 'It's this side that gives me the strength to make it to another day.' (Palmer 1999)

A personal remark may be allowed. I agree with Breeze's opinion, even though or rather because I am working as a volunteer in the "business of charity". She expresses my own frustration and desperation in many work situations. Politics and politicians are asked to find solutions for the global misery, but as long as they do not assume their responsibility we cannot abandon the many people in need of help. This interview already considers main thoughts of my summary of Caribbean women's poetry on mothering and children.

The five Caribbean women poets whose poems have been analysed so far have, indeed, a resonant voice. Their mouths cannot be muffled anymore. Linguistically, they use the whole Caribbean language continuum from Standard Eng- 
lish through a Standard English with an easily decodable touch of Creole phonology to a phonetic transliteration of Jamaican Creole. They reach what the literary critic Carol Cooper termed "oraliterary" status in order to describe the "interrelation of oral and literate characteristics" (Donnell and Welsh 1996, 24). They remake oral traditional forms like proverbs and nursery rhymes into a textual form and use this popular knowledge subversively. In their poetics, these poets draw on both traditional European and African verse forms and imagery - often, however, with revolutionary afterthoughts and a political message. These poets either compose their poems according to musical forms like blues and jazz or accompany them with music in performance poetry. This poetry bridges the gap between high and popular culture and reaches a broader audience. With all these linguistic, poetic and musical resources, poetry on mothering and children flourishes in many forms in Caribbean fiction. Additionally, Caribbean scholarship has provided a study on the issues of mothers and children with sociological and cultural data. The results of Olive Senior's Working Miracles - Women's Lives in the English-speaking Caribbean (1991) allow for a comparison between critical information and poetry. They prove that the poets have an open ear for the acute problems of their societies. Both discourses reveal a great deal of violence in Caribbean society caused by gender oppression, racism, cultural and class differences plus economic pressures. This applies to the home country as well to the British diaspora. Some poets, like Louise Bennett and Olive Senior, focus their attention on physical violence, tensions and conflict. Louise Bennett uses Jamaican creole and a subversive form of laughter. Olive Senior's poetry attempts to bring these conflicts under control. The perfect aesthetic display of her poems sometimes appears like a straight jacket. In a kind of "meta"-poem on childhood, she seems to sense the danger of posturing, of the propensity to make one's life into art. Her poems denounce the terrible indifference of modern societies concerning human relationships and the resulting suffering of mothers and children. Other poets like Lorna Goodison and Jean 'Binta' Breeze concentrate on the psychological dimensions of mothering and parenting and show how differences of race, class and cultural background impair the relationship between wife and husband, mother and father and between mother and children as well. Specific social and cultural formations require a changing awareness of mothering. In her poem "Testament", Jean 'Binta' Breeze shows this process of development of a black mother in the British diaspora. This mother learns that mothering requires an attentiveness to change due to the education and socialisation of her daughter. The poem attests to the changing understanding of children over time most prominently through the description of how the mother deals with her daughter's behaviour. These are painful steps and need the unselfish greatness of mothering to be experienced without resentment. Without the will to change and the rigid adherence to cultural and social norms, human warmth and joy in family life are at risk. Lorna Goodison depicts this situation in her poem "For My Mother (May I Inherit Half Her Strength)". Although I agree 
with most critics that this poem praises the mother for her almost superhuman strength, I cannot consent to an unrestrained celebration. The atmosphere of black family life in her poem and the poem "Testament" is so different. Feminist and post-colonial criticism demand a social and political engagement from art. Art is expected to draw on conflict and tensions rather than on peace and harmony. I tried to show that a close textual analysis reveals different aspects of a text. In the case of the poem "For My Mother", the revelation of a "maturity of acceptance" seemed to bear more importance for me than the insistence on endurance and sacrifice.

Similar to the Indian women poets, these poets from the Caribbean denounce the impact of class differences on mothering and the indifference of their society to deal with economic constraints and the resulting violence and despair. Whereas differences of race seem to be of subordinate significance in Indian poetry, the experience of racism is of main importance in Caribbean women's poetry, especially for women writing about the racism of a predominantly white society in the British diaspora. In contrast to Indian writers, who criticise the confinements inflicted on women by narrow forms of Christianity and Islam, Caribbean authors usually present the healing and encouraging role of tradition that encompasses Christian religion and African myth. In India, mothering seems to be a lonely affair, meanwhile in the Caribbean society the bonding of women, particularly the matrilineal bonding, seems to prevail.

Elaine Savory Fido, whose interpretation of the poem "For My Mother" I discussed, finishes her article on Caribbean women poets as following:

Perhaps another aspect of feminist and womanist dialogue is that critical response can cease to be a judgemental business and become much more a musing over the possibilities which literature brings to the life which experiences it. (In Davies and Fido 1990, 42)

Literature deals with differences of experience. Hopefully the negotiation of differences helps to overcome the indifference that the women poets denounced in their poems. This is also the main concern of the Caribbean poet Derek Walcott, who said in an interview:

I think pity has probably gone from the world. It's quite terrifying. I think there should have been nothing after the holocaust; nothing should have happened that was bad. [...] But the simple thing that Blake described when he spoke about pity, I think that is diminishing, frankly, in the experience of the world. [...] It isn't that one is more callous, but there is some kind of terrible indifference that goes on. And I think that the indifference is based on the fact [...] that science has taken over, that we think of science as an excuse for a lack of prayer, in a sense, a lack of devotion, a lack of compassion, of pity. [...] We read for information. We don't read to be touched. But what poetry does, and yes, that is the power of poetry - as Owen said, the power is in the pity - if that can touch, yes it has power, but in terms of wielding the power, that is something else. (Burnett 1988, 151-152) 
Derek Walcott particularly mentions his observation that "we absorb massacres, earthquakes, genocide and the starving in Africa as a part of daily life". Poetry on mothering and children by women poets from Africa deals with these facts. This is the issue of the next poem: the unique female experience of mothering - of childbearing, birthing and childrearing - can turn into mourning and the feeling of guilt. This poem by Lorna Goodison links the Caribbean part to the chapter on women's poetry from Africa.

The Woman Speaks to the Man Who Has Employed Her Son ${ }^{50}$

Her son was first made known to her as a sense of unease, a need to cry for little reasons and a metallic tide rising in her mouth each morning. Such signs made her know that she was not alone in her body. She carried him full term tight up under her heart.

She carried him like the poor carry hope, hope you get a break or a visa, hope one child go through and remember you. He had no father. The man she made him with had more like him, he was fair-minded he treated all his children with equal and absolute indifference.

She raised him twice, once as mother then as father, set no ceiling on what he could be doctor earth healer, pilot take wings. But now he tells her he is working for you, that you value him so much you give him one whole submachine gun for him alone.

He says you are like a father to him. She is wondering what kind of father would give a son hot and exploding death when he asks him for bread. She went downtown and bought three and one third yards of black cloth and a deep crowned and veiled hat for the day he draw his bloody salary.

${ }^{50}$ Goodison, Lorna. „The Woman Speaks to the Man Who Has Employed Her Son“. For Us, All Flowers Are Roses. Urbana and Chicago: University of Illinois Press, 1995. 51-52. 


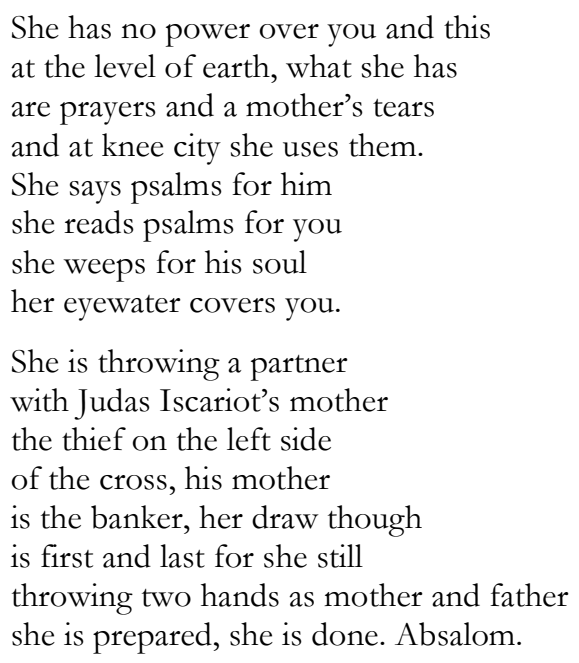

The poem's title, its length, its elaborate and ceremonious stanza-structure suggest that the anonymous speaker, the woman, addresses a serious issue: we cannot expect an informal conversation. In addition to this, the speaker of the poem is an omniscient narrator, not the woman herself. In this way, the poem transcends the mere personal and speaks about an experience which is shared by many women. The poem comprises six stanzas, each of eight lines. The first five stanzas are equally shaped, each begins with four unrhymed lines in irregular iambic tetrameter. The halt at the end of every fourth line slows the pace down. With its prevailing mood of melancholy and reasoning, this poetic form is suitable for an anthem or a mourning verse. The poet has selected a poetic form which has famous precursors. In the Renaissance period, the Metaphysical poets John Donne, George Herbert and Andrew Marvell used it to express their feelings towards another person or to examine the relationship between the individual, society and religion. Ben Jonson used it for "An Elegy", a love poem. Alfred Tennyson used it for his key work "In Memoriam A.H.H.," an elegy on the death of a close friend. Lorna Goodison has chosen a poetic form which has to obey the principles and practice of writing verse traditionally from a male point of view. The poet adapts the poetic form to her issue: a mother's speech to the man who made her son a childsoldier.

The poem obeys the described poetic form in the first four stanzas. In the fifth and sixth stanza, shorter lines and the interjection of dimeters create the impression of greater speed and urgency. This observation applies also to the syntax. The poem begins with ordered and complete statements and ends with inverted and broken sentences. The first stanza reflects on the symptoms of early pregnancy. The first quatrain describes the physical and psychic changes, the depressive and quickly changing mood and the nausea in the morning. The second quatrain observes the foetus. In this stanza, the disposition of alliteration and stress 
creates a solemn language. The repetition of consonants determines the key words, "Her son was first known to her / as a sense of unease, a need to cry / for little reasons and a metallic tide rising in her mouth each morning. / Such signs made her know / that she was not alone in her body. She carried him full term tight up under her heart." Additionally, each of the first four lines ends with a heavy stress thus slowing the rhythm down. These details build up the Biblical association of the Announcement of the Virgin Mary. The second stanza works with an opposition between both quatrains. The caesura in the fourth line highlights this contrast. The deep emotions and high expectations of the mother for her son are set against the indifference of the father. For the mother, the son is unique. He carries hope for the present and for the future. For the father, however, he is only one child among many others. The father only begot him and remained absent. The third stanza presents the central opposition of the poem, the opposition between the past which was a time of confidence, hope and dreams for mother and son alone and the present time. The presence is filled with death and guns after the intrusion of a man who assumed the role of a father. Due to her double role and double responsibility as mother and father, the mother dreams of her son's unlimited abilities. She envisions him as doctor, earth healer, pilot - in short, as the Redeemer of the world. Her wishes are set against the son's present decision to work for a war-lord. The fourth stanza foregrounds the son like the first stanza ("Her son", "He says"). It sets the present separation of the son from his mother against the closeness during pregnancy. Whereas the mother stands for procreation and life, the father represents death and murder. Her son's pay-day will be the day of his death for his mother. She prepares for a funeral. In the fifth stanza, the first quatrain consists of an inverted, knotted sentence that suggests a state of turmoil, confusion, desperation and the urgency to make a decision. Her prayers and tears still include the war-lord for a short period of time. Then she realises the uselessness of her actions so far and sets her own deal against these male gangsters. If life is not more than card-playing, she will beat the men with their own weapons. She becomes an accomplice of Judas Iscariot's mother, partner of a traitor's mother. Her poem closes with an outraged cry of defiance and desperation. If the life she has given to her son is nothing else than a poker party, then she holds all the trumps. She meets the challenge because she holds the cards of two persons, of mother and father. She is at the end of completion, she is done. The poem puts a stress on "done" like the tolling of a great bell which is followed by a threat and a curse. Absalom was David's third son. He murdered his half-brother Amnon and waged war against his father David. He is the paradigm of utmost rebellion and depravity. From the peaceful and tender association of Virgin Mary's Announcement, the poem moves to the figure of Absalom from the Old Testament, who is the personification of crime and revolt.

In the development of this "anthem", Lorna Goodison demonstrates a masterful interplay of form and content. Working with a highly traditional form of 
poetry, the poet defies several taboos. She lets a woman speak about her pregnancy. She underlines the liberty of a single mother to have unlimited dreams for the future of her son. She endows this mother with the strength and power to revolt against the reality of war-lords and child-soldiers. Many traditional poems about death, war and loss search to redeem in some way the painful reality by setting memory of the dead or love against destruction. This poem gives the impression of a totally inhuman and brutish reality and denies any escape and redemption. But after a stage of paralysis, this mother decides not to accept passively everything further on. She will fight back and calls for revolt against male destruction of humanity.

In reference to the Bible, this mother can be compared with David, both find a way out of a seemingly hopeless situation. Both fight against apparently invincible enemies. In reference to Gayatri Chakravorty Spivak, this mother develops a "strategic essentialism": she mobilises resistance at a particular moment that she derives from her individual consciousness as mother. But I would rather not apply this "propagandistic" term to this poem that expresses intimacy and deep emotions in many parts. 


\section{English Poetry by Women from Africa and the Diaspora: Mary Laurene Browne - Ingrid Jonker - Ingrid de Kok - Mwana Kupona binti Msham - Micere Githae Mugo - Ama Ata Aidoo - Stella P. Chipasula - Jeni Couzyn - Kristina Rungano - Irène Assiba d'Almeida and by Men: Kofi Awoonor - Lenrie Peters}

At the World's Congress of Reresentative Women in 1893, Francis E. W. Harper, the anti-slavery activist whom I presented in the introductory chapter, declared:

Through weary, wasting years men have destroyed, dashed in pieces, and overthrown, but to-day we stand on the threshold of woman's era; and woman's work is grandly constructive. In her hands are possibilities whose use or abuse must tell about the political life of the nation, and send this influence for good or evil across the tracks of unborn ages. (Lauter, ed. 1998, 688)

Yet women in Africa had to wait more than a century to cross this threshold. To put an end to the brutality of male government is the main goal of Ellen JohnsonSirleaf, the first woman President of an African nation. In spring 2006, she was elected head of state in Liberia after the first democratic election after fifteen years of a bloody civil war with more than 200,000 dead, among them many childsoldiers. The confessions of survivors revealed unimaginable atrocities committed by child-warriors during the war: executions of their own families, mutilations, murder of unborn infants, disembowelment of pregnant women, cannibalism etc., etc... The human imagination cannot fathom what people can do to each other. In the difficult process of their rehabilitation, motherly women are often the first to gain their confidence and to find access to their wounded and, hopefully, not yet totally destroyed human core. 
I have been working in two African countries suffering from the devastation of war: in Darfur/Sudan, in 2004-2005, where the fighting continues, and in Liberia in 2003 shortly after the peace treaty. I wanted to include poetry by women from these countries into my thesis, but there is no substantial material available, neither publications of poetry nor autobiographical data of writers. Women writers in Sudan usually write in Arabic. In Liberia almost all libraries and bookstores had been looted, burnt down or otherwise destroyed during the war. My impression of Africa has been formed by this experience and by encounters and conversations with African women working for peacebuilding. In Liberia, the year 2003 had been a year of increased hostilities, constant attacks, continuous destruction of lives and mass displacement of people. This prompted the non-violent "Mass Action of the Women." They placed themselves and their children in the theatres of war and, finally forced the fighting "rebel" groups into peace-negotiations in Accra. The movements of non-violent mass actions have a longer tradition in Africa. In 2002, the Women in Peacebuilding Network (WIPNET) Liberia Chapter had been established as a component of the West Africa Network for Peacebuilding (WAPNET). According to a brief information paper, the goal of the WIPNET is to "increase women's participation in holistic peace-building at all levels". It has the "Vision of a Liberia where women will stand up for their rights, be focused in working for peace with clear goals and objectives about initiatives." The time after the peace treaty was a time of new departures for Liberia. Many artists engaged in grassroots activities in order to support the process of disarmament and democracy-building, e.g. the Flomo Theatre Production Inc., a nonprofit organisation, whose work was supported by the Deutsche Welthungerhilfe. The program included the training of youth groups for the promotion of peace and reconciliation, civic votes education at the community level, health education through dramas, forum theatre to sustain peace and democracy. The Flomo Theatre used traditional and well known folk songs and folk dances to convey their messages.

\section{Mary Laurene Browne}

During my stay in Monrovia in summer 2004, Ms Mary Laurene Browne OSF, President of the Association of Liberian Women Writers, provided me with helpful information in a friendly conversation. Although my research has not been successful in including Liberian women's poetry, I want to express my gratitude and insert the list of names in order to support further investigations. Writers with publications of poetry are Mary Laurene Browne herself, Virginia Sherman, Yvonne Reeves, Victoria T. Ireland, Lolita Richardson, Erusala David, Jebeh Kawah. Mary Laurene Browne presented me with a copy of one of her poems that I include here. 
This is Africa's Women

Her wings are spread

but cultural norms

delay the flight

for yet another decade

maybe two

or

perhaps a century more

She knows not to read the times

or raise her voice to speak her mind

The toil continues from dawn to dark

in fields and homes

for kith and kin

And when at last she hits the mat

The infant cries to get its fill

another, feverish whimpers by

demanding only a mother's touch

O woman African

of many hues

So many burdens your spirit bruise

This flight delayed

will soar high

rising higher, higher, higher

a must for you

a must for Africa

In her poem, Mary Laurene Browne depicts the traditional picture of an African woman: she is "working miracles", mother of many children, totally absorbed in everyday duties and set back by history and contemporary politics. But the present political scenery indicates changes. African women play an ever increasing role in the decision making processes of their countries and of the whole continent. South Africa, Simbabwe and Burundi have women Vice-Presidents. In Sao Tome and Principe, the heads of government are women. Ruanda has the highest percentage of women parliamentarians world-wide. These women are self-confident, well educated, often experts in financial and economic affairs. With their colourful African dresses and fantastic head-scarves, they both honour their cultural heritage and cause a sensation on the international political stage. After this excursion to personal encounters and some observations on present politics in Africa, I will return to women's poetry on mothering.

Confronted with the vastness of this huge continent with its enormous ethnic, geographical, historical, developmental, cultural, political and economic differences, I asked myself how to approach African women's poetry. In order to avoid repetitions, I have structured this chapter differently from the preceding chapters 
on women's writing from India and the Caribbean. Instead of presenting some women poets in more detail, I will concentrate on two main issues: on children as victims and on pregnancy and child-birth. In this way, this last chapter inverts the direction of the poem "The Woman Speaks to the Man / Who Has Employed Her Son." Additionally, I will consider the difference of gender and include two male voices in order to make visible a gendered view on children and childbirth.

The 1960s witnessed a growing international interest in African literature. Until the 1980s, however, African literature remained a male domain concerning publications and literary criticism. The first African writers who achieved publication were men. Flora Nwapa's novel Efuru, published in 1966, is one of the rare exceptions. The earliest critics of African literature were European and American academicians who approached the texts from a male point of view, for example, Wilfred Cartey's Whispers from a Continent (1971) that I mentioned in the introduction. The author directed his attention to the importance of the mother-childrelationship in African literature both as a topic and as a symbol. Roseann P. Bell's Sturdy Black Bridges: Visions of Black Women in Literature (1979) is regarded a landmark work because it is the first collection of women's critical essays on the images of black women in literature. At almost the same time, the first critical books on individual African women writers appeared, for example, Lloyd W. Brown's Women Writers in Black Africa (1981). The author analysed the novels and short stories of Buchi Emecheta, Efua Sutherland, Ama Ata Aidoo, Flora Nwapa and Bessie Head. He claimed that the writing of these women should be approached as committed works of art in which the political message is integrated. In Ngambika - Studies of Women in African Literature (1986), the editors Carole Boyce Davies and Anne Adams Graves expanded the scope of their research. The essays focus on both the depiction of women from a male perspective and present women's own conscious self-perception. Additionally, they deal with political and social institutions in African societies, that influence women's lives: marriage in its many forms, the domestic sphere of the family including motherhood and grandmotherhood, child-custody and in-law relationships. Their authors argue that a feminist consciousness is necessary to intrude into the male-dominated area of literature and literary criticism. Writing by African women presents cultures and traditions in both a positive and a negative light: as an encouragement and a source of imagination as well as an imprisonment and a restriction of women's rights. Similar to Olive Senior's claim for Caribbean women in her study Working Miracles, African feminists make clear that women have to overcome internalised ideologies of patriarchy and gender hierarchy in order to develop a new self-perception and to define their freedom. They challenge prescribed female roles and the romanticisation of motherhood within the socio-economic and cultural context. African feminist consciousness has a socialist and womanist orientation by drawing attention to the interconnectedness of race, class and sex oppression. 
African feminism always assumed responsibility for feminist concerns and the problems of the African society.

African feminist literary criticism is both textual and contextual criticism that takes into consideration the integration of form and content in a work of art together with the social vision and the political message. It is based on the AfricanAmerican feminist theory and linked to the works of Barbara Christian, Barbara Smith, Deborah McDowell and Alice Walker, which I discussed in the theoretical part of my thesis. In the book's title, the Tshiluba phrase Ngambika signifies "Help me to balance / carry this load." It connects the traditional image of the African woman carrying heavy loads on her head with the hybrid form of African feminism that seeks to keep the balance of so many concerns and influential trends. African women's poetry reflects most of these aspects and mirrors the publishing scenery: the publication of an anthology of African women's poetry had to wait until 1995. Susheila Nasta's review of this book vividly summarises the drawbacks African women writers have suffered so far and expresses hope for a change:

The publication of this anthology of African women's poetry marks an important milestone in the history of the publication of African women's writing. [...] Paradoxically, whilst woman as 'Mother Africa' or Earth Mother, has been an important and recurrent icon or trope in African poetry by men - poets such as Leopold Senghor of the Negritude movement are famous for their nationalistic worship of African woman's black body as the land of Africa for instance - the voices of women themselves have been conspicuously absent both from critical debates and the selections of editors. [...] This book deserves praise for its painstaking excavation of a whole wealth of material that has been in danger of disappearing from view altogether. [...] One hopes too that the Heinemann African Writers Series ghettoised as it usually is by mainstream reviewing practice - will provide the anthology with an adequate home. (Nasta 1996, 72)

The Heinemann Book of African Women's Poetry edited by the Malawian poets Stella and Frank Chipasula has been a treasury for my work. The examples of men's poetry are taken from A Selection of African Poetry (1976). The editors, Kojo Senanu and Theo Vincent provided it with an introduction and with annotations to promote the study of African poetry at schools and universities in Africa; but they did not include a single female voice. As already indicated, the poetry part begins with political poetry from South Africa where children feature as victims of Apartheid politics.

Already from the beginning of white settlement, life in South Africa had been dominated by conflict between the different racial groups. The utmost separation of the races was reached under the totalitarian Law of Apartheid which governed South Africa from 1948 until 1994. In 1965, for example, it governed the minority of white Africans (3,395 million), the majority of black Africans (12,162 million), people of colour (1,742 million) and 0,533 million people from India. Only white Africans had the privilege of franchise and elegibility. Segregation included inter- 
personal relationships, displacement to ramshackle townships, poverty, the withholding of education and constant threat and violence. A statement of Henry Vervoerd, Prime Minister in 1953, elucidates the repression:

If the native in South Africa today, in any kind of school in existence is being taught to expect that he will live his adult life under a policy of equal rights, he is making a big mistake. There is no place for him in any European community above the level of certain forms of labour. (Wisker 2000, 160)

At the beginning of the 1970s, however, the Black Consciousness Movement radically changed the situation. Black people began to protest against the regulations for Bantu education. The Soweto uprising in June 1976, with its murder of many children, finally directed world wide attention to South Africa's predicament. The following years signalled the decline of white supremacy. Finally in 1994, the black majority reached representative participation in the political process as a result of democratic elections. Black writers denounced the bloody events in their work, for example, Mbulelo Mzamane in The Children of Sowveto (1982) and Miriam Tlali in Soweto Stories (1989). There were many white writers who protested against Apartheid risking imprisonment and life. Even Nobel laureate Nadine Gordimer and the two Afrikaner women poets Ingrid Jonker and Ingrid de Kok were among them.

\section{Ingrid Jonker (1933-1965)}

Ingrid Jonker began writing poetry as a child. In 1963, she published her prizewinning book Rook and Ochre (Smoke and Ochre). In July 1965, she took her life after her estrangement from her father, a prominent newspaper editor and $\mathrm{Na}$ tionalist Party official. She originally wrote in Afrikaans and translated her poems into English. Following her death, South Africa instituted the Ingrid Jonker Prize for Poetry in honour of one of the most original South African poets.

\section{The Child who was Shot Dead by Soldiers at Nyanga ${ }^{51}$}

The child is not dead

the child lifts his fist against his mother

who shouts Africa! shouts the breath

of freedom and the veld

in the locations of the cordoned heart

The child lifts his fist against his father

in the march of the generations

who shout Africa! shout the breath

\footnotetext{
51 Jonker, Ingrid. "The Child who was Shot Dead by Soldiers at Nyanga". The Heinemann Book of
} African Women's Poetry. Eds Stella and Frank Chipasula. London: Heinemann, 1995. 151. 
of righteousness and blood

in the streets of his embattled pride

The child is not dead

not at Langa nor at Nyanga

not at Orlando nor at Sharpeville

nor at the police station at Phillippi

where he lies with a bullett through his brain

The child is the dark shadow of the soldiers

on guard with rifles, saracens and batons

the child is present at all assemblies and law-givings

the child pees through the windows of houses and into the hearts

of mothers

this child who just wanted to play in the sun at Nyanga is

everywhere

the child grown to a man treks through all Africa

the child grown into a giant journeys through the whole world

Without a pass

This poem comprises four stanzas of five lines and ends with a triplet. There is a striking disparity between the lines which grow in length from the beginning to the end of the poem. The concluding line, however, is the shortest as if the poem were coming to an abrupt and unexpected climax. There is no rhyming pattern, but a clear purpose to the line length and a repetition of consonants to determine the key words. The poem works with oppositions. The first lines of every stanza contradict the title that suggests a poem about a dead child. But the stanzas repeat again and again, "The child is not dead", "The child lifts his fist", "The child is the dark shadow of the soldier", "The child grown to a man...", "The child grown to a giant...." This enumeration transcends the singularity of the event and culminates in the message that "that this (particular) child who just wanted to play in the sun at Nyanga is everywhere." The poem works with another contrast: the silence of the child is set against the rumour and shouting of the adults: in the beginning, the child lifts his fist as a threatening gesture; but after the bloody event, the child becomes a ghost. In this part, the poem most conspicuously works with alliteration in order to indicate the key words and to connect past and present time, "at the police station of Phillippi / where he lies with a bullett through his brain / the child is present at all assemblies and law-givings / the child pees through the windows of houses and into the hearts of mothers / this child who just wanted to play in the sun of Nyanga is everywhere." The rhetorical tools of contradiction and enumeration and the poetic devices of alliteration and length of lines convincingly develop the message: black people are becoming a threat for the world. The poem ends with the omnipresence of black people and presents this vision as a menace f. This poem, written in the 1960 s, conjures up contemporary everyday 
experience. The poem's long lines seem to represent the endless queues of hungry, or even starving and exsiccated, Africans who try to escape from Africa's eternal predicament to the supposedly Promised Lands of the western world.

\section{Ingrid de Kok $(* 1951)$}

Ingrid de Kok was born in South Africa in 1951. She studied Politics and English in South Africa and English Literature in Canada. She has published a book of poems, Familiar Ground, in 1989.

Al Wat Kind Is ${ }^{52}$

'They took all that was child in the house.'

(resident of Victoria West, reporting on police action in the town)

They took all that was child

and in the dark closed room

visions of a ripe split melon

were at the tip of the knife

they held to the child's dry tongue.

All that was child

lies on the tarmac;

the intestines spill

like beans from a sack,

seaweed from the winter sea.

The bird of state has talons

and shit that drops like lead.

Its metal wings corrode the streets,

it hatches pools of blood.

A stone against a tank is a stone against a tank

but a bullett in a child's chest rips into the heart of the house.

But when in time the single stones

compact their weight and speed together,

roll up the incline towards the lamvanger's lair,

crushing sand into rock, rock into boulder,

boulder into mountain, mountain into sky,

then the lungs of the bird will choke,

the wings will blister and crack,

at last the eyes will glaze, defeated.

And this torn light, this long torn light

52 De Kok, Ingrid. “Al Wat Kind Is". The Heinemann Book of African Women's Poetry. Eds. Stella and Frank Chipasula. London: Heinamnn, 1995. 183. 
will repair itself

out of the filaments of children,

and all that is child will return to the house,

will return to the house.

This poem consists of two parts that are separated by a couplet which summarises the content of the poem: a child threw a stone against a tank and was shot dead by soldiers. The first part describes in detail the terrible wounds of the butchered child inflicted by the brutality of the executive power. The state power is represented in the second stanza by the bird of state. At the poem's centre, the couplet states the disproportionate relation of violence and counter-violence, "A stone against a tank is a stone against a tank / but a bullet in a child's chest rips into the heart of the house." The second part uses a solemn, almost Biblical language. Its enumerations conjure up a mass action that develops out of the single stone and will lead to the destruction of the oppressive state. Similar to Ingrid Jonker, Ingrid de Kok works with oppositions. She uses the contrast of language level and of images. Images of the "dark closed room" are set against the vision of "light", "the ripe split melon" stands against the "repair out of filaments". The poem suggests a vision of change and return and a beam of hope although the horror is depicted in such a frightening, subtle form.

Francis E. W. Harper, whose poem "The Slave Mother" I analysed in the introductory part, wrote the poem "The Martyr of Alabama" that is similar in content and structure. Whereas in de Kok's poem the statement of an eye-witness follows the title, in Harper's poem the original newspaper report appeared:

The following news item appeared in the newspapers throughout the country, issue of December, 1894.

"Tim Thompson, a little negro boy, was asked to dance for the amusement of some white toughs. He refused, saying he was a church member. One of the men knocked him down with a club and then danced on his prostrate form. He then shot the boy in the hip. The boy is dead; his murderer is still at large". (Lauter, ed. 1998, 691)

Has nothing changed within the last hundred years?

Small Passing 53

for a woman whose baby died stillborn, and who was told by a man to stop mourning, for the trials and horrors suffered daily by black women in this country are more significant than the loss of one white child.

1

In this country you may not suffer the death of your stillborn,

${ }^{53}$ De Kok, Ingrid. "Small Passings". The Heinemann Book of African Women's Poetry. Eds. Stella and Frank Chipasula. London: Heinemann, 1995. 181. 
remember the last push into shadow and silence, the useless wires and cords on your stomach, the nurse's face, the walls, the afterbirth in a basin.

Do not touch your breasts still full of purpose.

Do not circle the house, pack, unpack the small clothes.

Do not lie awake at night hearing the doctor say 'It was just as well' and 'You can have another.' In this country you may not mourn the small passings.

See: the newspaper boy in the rain will sleep tonight in a doorway.

The woman in the busline may next month be on a train to a place not her own.

The baby in the backyard now will be sent to a tired aunt, grow chubby, then lean, return a stranger.

Mandela's daughter tried to find her father through the glass. She thought they would let her touch him. And this woman's hands are so heavy when she dusts the photographs of other children they fall to the floor and break.

Clumsy woman, she moves so slowly as if in a funeral rite.

On the pavements the nannies meet.

These are legal gatherings.

They talk about everything, about home, while the children play among them, their skins like litmus, their bonnets clean.

2

Small wrist in the grave.

Baby no one carried live between houses, among trees.

Child shot running, stones in his pocket, boy's swollen stomach full of hungry air.

Girls carrying babies not much smaller than themselves.

Erosion. Soil washed down to the sea.

3

I think these mothers dream 


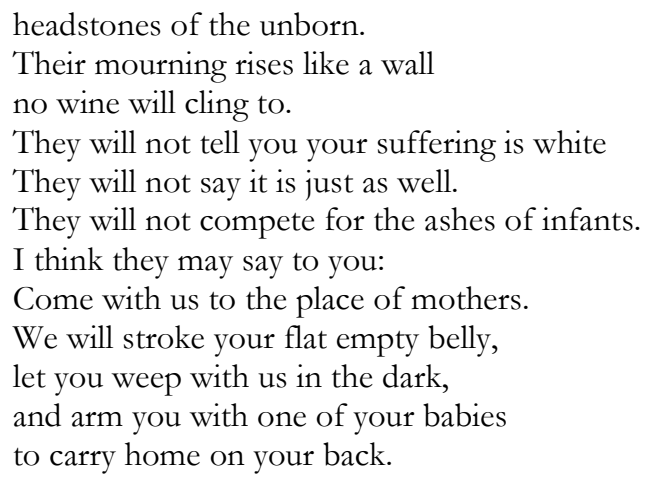

This poem is directed against merely rational dealing with loss, pain and mourning. It is not possible to quantify and to compare suffering. The poem envisions and seeks refuge in solidarity among black and white women. White and black mothers who lost their children feel the same pain and comfort each other.

The power of this poem lies in the detailed and intimate description of the events. The poem consists of three sections of different length. The first section contains three parts, two of almost equal length and a short one. The first part remembers the sterile atmosphere of the clinic and the mindless or helpless effort of the doctor to find a form of consolation. The second part deals with the suffering of black children. It mentions the homeless, the displaced, those estranged from their parents. It thinks of children remembered in photographs that escape the hands of the woman dusting them. The third short part gives an impression of the apparently careless life of white children and their nannies. The meeting of nannies is the only legal gathering in a state of martial law. The second section resumes the content of the first but leads to a different perspective. It looks first at the stillborn baby. Then it concentrates on the suffering of living children who have to face murder, hunger and loss of their parents. The last line draws the conclusion "Erosion. Soil washed down to the sea". Erosion describes the process by which the surface of the earth is washed away. The remaining sand or stone is infertile and hostile to human life. The same applies to the South African society that withholds shelter, food and prospects for the future from their black citizens who form the majority. The poem describes the changing awareness of a white woman. Mourning over her still-born baby, she pays more and more attention to the suffering of black children who surround her. The third section imagines a community of black and white mothers. It is a vision of human warmth and of a closeness of bodies, minds and hearts.

The poems from Africa analysed so far, seem to confirm the prejudice that women's writing is mostly concerned with their suffering and their role as victims. Yet my work started with the intention to dismiss this generalisation. The last poem ends with the traditional image of an African woman - either black or white - with a baby strapped on her back. This lively image leads to the next part of my 
work. It returns to living children and to poems addressed to daughters by four female and one male poet. Unfortunately, I could not find more poems on this topic written by men - an incident or a symptom of gender difference? I have deliberately chosen poems from different African countries. The short geographical and historical contextualisations can only outline the cultural, social and political 'infinite variety' of this huge continent.

\section{Mwana Kupona binti Msham (c.1810-c.1860)}

I begin with a poem from the nineteenth century that leads us into the multiculturalism of Kenya. Kenya is the centre of the Swahili culture that developed since the nineth century when Arabic merchants settled down at the East-African coast, the native country of the Bantu people. They developed urban states which were governed independently and created an oriental culture based on the common language Swahili and on Islamic religion. At present day, some prodigally equipped mosques and palaces still testify to this culture. This is the context of the following poem.

Mwana Kupona binti Msham was a pioneer nineteenth-century Swahili woman poet from Kenya. She was the widow of the influential and famous Sheikh Mataka ibn Mbaraka who waged war against the Sultan of Zanzibar. Mwana Kupona had two children, a son and a daughter, Mwana Hashima binti Sheikh, for whom she wrote her well-known "Poem of Mwana Kupona" in 1858.

from Poem to her Daughter ${ }^{4}$

Daughter, take this amulet

tie it with cord and caring

I'll make you a chain of coral and pearl

to glow on your neck. I'll dress you nobly.

A gold clasp too - fine, without flaw

to keep with you always.

When you bathe, sprinkle perfume, and weave your hair in braids

string jasmine for the counterpane.

Wear your clothes like a bride,

for your feet anklets, bracelets for your arms...

Don't forget rosewater,

don't forget henna for the palms of your hands...

Translated from the Swabili by J.W. Allen; adapted by Deirdre Lashgari

In anticipation of her death, the poet as mother wrote a long poem in order to introduce her daughter into her different roles as woman. This short part prepares the daughter for her marriage. The sensual description of fragrances and the dis-

${ }^{54}$ Mwana Kupona binti Msham. "Poem to her Daughter". The Heinemann Book of African Women's

Poetry. Eds. Stella and Frank Chipasula. London: Heinemann, 1995. 126. 
play of gems create the atmosphere of Thousand-and-One-Night. The mother guides her daughter gently and carefully into the art of seduction, "When you bathe, sprinkle perfume", "string jasmine for the counterpane". The same intuition lies behind the exhibition of jewels and the painting of the skin. The mother is, however, not only concerned with her daughters appearance. These pieces of jewellery serve as amulet, as protection against evil fate. Pearls and corals have a special meaning in popular belief. Pearls are often regarded as symbols of innocence or as defence against infidelity. Pearls as pendants, for example, are designed to close the ears against seductive insinuations. Corals are often connected with blood. In ancient Egypt, corals accompanied the dead into their graves. Catholic tradition makes use of corals for rosaries and figures of saints that serve as amulets as well. This is a beautiful sensual feminine piece of poetry about a mother's love and pride. It also describes a relationship of women and men that was still unaffected by the claims of feminism. Still fascinated by the fairy-tale like tone of this poem, I regret the incomplete presentation of poetry if the native voice remains silent. The original of a poem in a foreign language should be available together with the English translation - and not only in the written but also in the recorded version. It is always a fascinating experience, to imagine the meaning of a poem spoken in a foreign language from the atmosphere rendered by the recitation. I addressed the issue of translation in my introduction and refer to it.

\section{Micere Githae Mugo (*1942)}

The setting of the preceding poem was Kenya's Muslim culture of the early nineteenth century. At the end of the nineteenth century, more and more white colonists settled down at Kenya. In 1895, Kenya became a British protectorate and in 1920 colony of the British crown. In 1952, the tribe of the Kikuyu initiated the mau-mau uprising against the British power politics. After a bloody war, Kenya received its independence in 1963. The leader of the resistance movement, Jomo Kenyata, who had been imprisoned for many years, became Kenya's first president and ruled until 1978. In comparison to other African countries, Kenya is relatively stable and successful concerning its politics and economy. Under the influence and the demands of mass-tourism it is, however, on the way towards "westernisation".

Micere Githae Mugo was born in Kenya in 1942. She received a teaching diploma from Nairobi University and an MA and PhD from the University of New Brunswick, Canada. In 1980, she was elected Dean of the Faculty of Arts at the University of Nairobi. She was the first woman faculty dean in Kenya, possibly in all of Africa. She became involved in the revolutionary process in Kenya and was forced into exile with her two young daughters in 1982. From 1982 until 1993, she taught at the University of Harare, Zimbabwe. She is now a professor in the Department of African American Studies at Syracuse University. She considers her- 
self a Pan Africanist, a Marxist, and a Black Feminist. As a representative of Amnesty International, she speaks on issues of human rights with particular attention to the situation of African women. In an interview from 1986, she described and defined the role and the task of the woman writer in Africa:

My call to African women writers is to find ways and means of reaching the majority of our people, who are women, to speak for them. [...] There is nothing wrong with singing about women but I think we must be very careful to define and specify which women we are singing about. I still insist that we must sing and sing again about our mothers out there in the rural areas, in the high density 'suburbs', and their poverty. This song can never be too much because it is the song of Africa. (James 1990, 98-99)

The publications of Micere Githae Mugo include two collections of poetry, Danghter of My People, Sing! (1976) and My Mother's Poem and Other Songs (1994); two plays, The Long Illness of Ex-Chief Kiti (1976) and jointly with Ngugi wa Thiong'o The Trial of Dedan Kimathi (1976); and a book of criticism, Visions of Africa (1981).

Where are those songs? 55

Where are those songs

my mother and yours

always sang

fitting rhythms

to the whole

vast span of life?

What was it again

they sang

harvesting maize, threshing millet, storing the grain...

What did they sing

bathing us, rocking us to sleep...

and the one they sang

stirring the pot

(swallowed in parts by choking smoke?)

What was it

the woods echoed

as in long file

my mother and yours and all the women on our ridge

beat out the rhythms

trudging gaily

as they carried

piles of wood

55 Mugo, Micere Githae. "Where are those songs?" The Heinemann Book of African Women's Poetry. Eds. Stella and Frank Chipasula. London: Heinemann, 1995. 129-131. 
through those forests

miles from home

What song was it?

And the row of bending women

hoeing our fields

to what beat

did they

break the stubborn ground

as they weeded

our shambas?

What did they sing

at the ceremonies

child-birth

child-naming

second birth

initiation...?

how did they trill the ngemi

what was the warrior's song?

how did the wedding song go?

sing me the funeral song.

What do you remember?

Sing

I have forgotten

my mother's song

my children

my children will never know.

This I remember:

Mother always said

sing child sing

make a song

and sing

beat out your own rhythms

the rhythms of your life

but make the song soulful

and make life

sing

Sing daughter sing

around you are

uncountable tunes

some sung

others unsung

sing them

to your rhythms

observe 


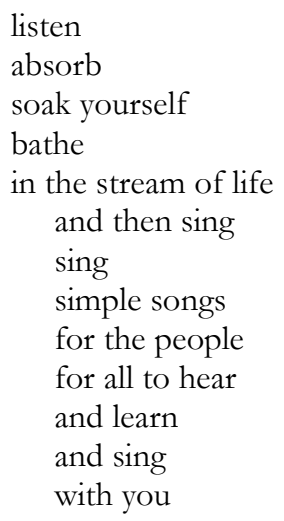

This poem praises the matrilineal heritage and follows the formula of traditional African poetry. The first part is a nostalgic commemoration of songs sung by African mothers. These songs are coupled with the activities of women in rural Africa, "harvesting maize, threshing millet, storing the grain, stirring the pot, trudging gaily as they carried piles of wood [...], hoeing the fields" and of mothers, "bathing us, rocking us to sleep". The poem enumerates categories of secular songs that are common for all people of the world: lullabies to sing babies to sleep, courting songs, working songs with a set of skills and instructions, celebration songs, war songs, death songs. Like a traditional African mourning song, it works with the repetition of lines with slight variations that suggest a call-andresponse pattern. "Where are those songs?", "What was it again they sang?", "What did they sing?", "What was it?", "What song was it?" By recalling and celebrating the mothers' achievements, the poem reassures the continuity of life and develops into a song in praise of life. At first sight, this poem resembles the poem "Testament" by the Caribbean poet Jean 'Binta' Breeze. Perhaps it is a forerunner and example. But whereas in "Testament" the matrilineal heritage is set against the racism of a white society, in Micere Githae Mugo's poem the healing function and the positive attitude towards life develop directly out of the remembered songs. By celebrating the songs of African mothers, this poem rescues a traditional form that has been in danger of disappearing. Yet, most of all, this poem commemorates the everyday struggle and the self-esteem of African mothers as the main encouragement for their daughters.

\section{Ama Ata Aidoo (*1942)}

Christina Ama Ata Aidoo was born in the central region of Ghana in 1942. Ghana is situated at the West African coast. The population consists of seventy different ethnic groups who still have and use their own languages. English is the national and literary language. The Akan people are the dominant ethnic group. They 
founded a large empire that lasted from the eleventh until the nineteenth century. In the fifteenth century, Ghana's wealth of gold and ivory attracted European adventurers, who soon detected a new trade: the export of slaves to America. At Ghana's coast developed a rich white bourgeois society that was dominated by British citizens. In 1874, the country became part of the British Empire. The Akan tribes offered resistance for more than thirty years and were forced to give in in 1901. After the Second World War, Ghana began to struggle for independence. Dr. Kwame Nkrumah, the charismatic founder and leader of the Convention People's Party, lead the country as the first of the British colonies in Black Africa to sovereignty. He advocated the ideal of a Pan-African socialism without the arbitrary frontiers of the colonial past. But his dreams did not come true. Megalomaniac public buildings and corruption ruined the country. In 1966, the military forced him into exile. The political situation of the country remains unstable. Economically, Ghana is one of the poorest countries on earth and dependent on the International Monetary Fund. In Ghana, Akan culture and tradition still influence the social hierarchy with its chief-system.

Ama Ata Aidoo was the daughter of a chief and grew up in a royal household. She graduated from the University of Ghana in 1964. She had a junior research fellowship at the Institute of African Studies at the university. This knowledge directed her to use African oral tradition in her writing. She often alternates between prose and poetry in the manner of oral storytelling. She has always been a political activist, involving herself in Ghanaian politics, a writer and a teacher. She has taught English and African Literature at various African and American Universities. She is probably the best known African woman writer and has influenced the writing of many women authors in Africa. (Nasta 2004, 292).

Ama Ata Aidoo's publications include two plays, The Dilemma of a Ghost (1964) and Anowa (1970); a collection of short stories, No Sweetness Here (1970): two novels, Our Sister Killjoy (1979) and Changes: a love story (1991), two collection of poetry, among them Someone Talking to Sometime (1985); as well as numerous critical essays on African literature, gender, race and the position of women in African society.

In 2002, Aidoo (A) talked about her understanding of gender roles and feminism with Dr. Nana Wilson-Tagoe (TG), a scholar and critic of African and Carribean literature. Since this interview gives answers to urgent current questions, I have quoted this at length:

WT: You talked of a generational gap in the understanding of gender and feminism. [...] Can you elaborate a little on the social and global dynamics which created this gap?

A: Some of the dynamics that have helped the growth of this gap are outside the Academy, outside humanity. We are talking about a world where fundamentalisms of all sorts have arisen. Certainly from this side of the world, from Europe, it is almost as though the only fundamentalism in the world is Islamic fundamentalism. But we know very well that we are coping with Christian and other fundamental- 
ism. None of these fundamentalisms differ in how women are regarded. [ ] So it is almost as though, outside their prescribed traditional spaces, women are looked upon as some kind of threat to society. As far as I am concerned, it is almost as if our very existence as the other human being is regarded as something that has to be watched and possibly organized outside of ourselves. It is a very complex issue. [ ] The pressure on younger women to take grooming seriously as if we never came out of the 1920s. The fact is that whatever the feminist movement gave to the younger generation was not enough for them to withstand some of these pressures.

WT: [ ], you have always located a discourse on gender in the context of changes. [ ] there seem to be no rigid polarities between men's roles and women's roles, but rather a dialectic which sets up several perspectives with which transformation may take place. So was there anything about your understanding of gender in Akan society which made you envisage this view of fluidity?

A: [ ] Akan society is matrilineal and that is its major departure. I mean I did not say matriarchal because this is very different and people mistake the two. Matrilineal as in the simple business of the inheritance of material wealth and who matters: your grandfather or your grandmother; and within the Akan society it's your grandmother. And it is unbelievable. I have known women who have had up to four sons and who still consider themselves 'infertile' because they didn't have a daughter. [ ] I grew up in my father's house [ ] and I definitely knew that being a woman is enormously important in Akan society. [ ] In terms of women standing on their own feet, within or outside marriage, mostly from inside marriage, living life on their own terms. [ ] Of course, the head of the family is still a a man and we are taught that men are ruling in proxy for women in Akan society. [ ] For me the past few years in Ghana have been an eye-opener because that matrilineal thing has not gone away anywhere. [ ] The child in Akan society has something of a double inheritance, the father's and the mother's. You belong to your father's paramilitary organization but then you belong to your mother's clan. (Nasta 2004, 292-300)

Based on my observations in several countries of the "Third World", I fully subscribe to Aidoo's statements. On the one hand, economic independence - mostly obtained through work, sometimes through inheritance - entails a respected position for women in their families and their societies. It is, indeed, the first step of a new departure. In matrilineal societies, women, men and children have already experienced the advantages for many centuries. It is probably the most urgent task of feminism and other social and cultural movements, to realise these forms of matrilineal societies everywhere. On the other hand, however, we observe all forms of religious fundamentalisms that threaten this development.

Ama Ata Aidoo is a single mother of one daughter for whom she wrote the poem "For Kinna II". Being asked about mothering and family life, she answered that she regarded "mothering" as just one - and for a certain time central - occupation of women: 
Oh, being a mother! Traditionally, a woman is supposed to be nothing more valid than a mother. Sometimes on gets nervous of such total affirmation and total negation in relation to other roles that one has played. But I think that being a mother has been singularly enriching. [...] I did not set out to sacrifice family life for my writing. It just happened. However, this again is an issue which I feel very nervous answering. Sometimes I feel that the way I have been, I would have had a lousy family life whether my energies have been channelled into writing or not. Because it has to do with one's moods. Whatever sacrifices have been made, I want to assure you, they have not been deliberate. (James 1990. 13, 19-20)

\section{For Kinna $I^{56}$}

But

He said:

Princess, - and remember royalty

are

made

not born -

it is not for lack of what

you

could

have

had.

Step up this way and see

these valleys of

green grass that

the winds

the rain and

forever-sun have

rooted so firmly,

fanned up and

levelled down

as though it was a

UN-proto farm.

All that

can,

should,

must be yours.

If I could drive the malaria from my bones, accept what I cannot accept, then

lift

56 Aidoo, Ama Ata. "For Kinna II". The Heinemann Book of African Women's Poetry. Eds. Stella and Frank Chipasula. London: Heinemann, 1995. 47-50. 
up

my

gun and...

shoot.

Here on either side of

the great precipice,

time has not begun to get

restless:

the winds are so still

I asked a toucan for a drink, and

he heard me!

$\mathrm{Ah}$,

the land is truly beautiful.

The cattle are healthy, their udders are full.

And they might even

smile - at milking.

Especially now that their

milk and their

meat go to

far away places to feed

mouths that are less

hungry than our own.

As happens to the potatoes

we till

so slowly

so painfully:

using

ancient implements,

hoeing and

brushing.

Baby,

it couldn't have been

you that I

feared.

The noises

the praises

the blame:

and affection running as

thin as flax in the hands of a crippled dame,

and

my love

pawed by 


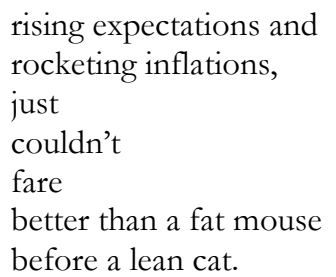

They say

they mean

us all to

walk

swim and

fly?

What do we do, but

crawl into

corners and die

who were born without

legs

fins or

wings?

No, there are choices I

couldn't face

even for

you,

My Little Queen.

In most of her writing, Ama Ata Aidoo represents relationships between men and women within the domain of politics and criticises at the same time Africa's fatal dependence on the West and, in some regions, the Middle and Far East. In her novels and plays, the writer manages to deal humorously with these political issues. Her three poems on mothers and children, however, conjure up bad dreams - post-partum complications, birth of monsters and a mother's anguish for the future of her child in this chaotic world.

The poem "For Kynna II" circles around the question, whether life is something that develops inexorably towards a pre-determined end, or whether it is a process that can be taken into one's own hand. The poem consists of four parts that are different in voice, tone, language and mood. It works on two levels. The first is the personal relationship between a man and a woman and a mother and her baby daughter. The second layer concerns Africa's relation with the West. It begins with an antithesis that develops its theme in the first part. The following sections build up the thesis and terminate in a defiant contradiction. The fragmentation of colloquial speech and the interplay of repetitive syntax and longer narrative lines follow the oral, but not distinctly "African", tradition. The poet works 
with oppositions and invents bold images full of irony or sarcasm, for example, "as though it was a UN-proto-farm", "my love [...] just couldn't fare better than a fat mouse before a lean cat". The first part has a male voice that objects to something that came before the initial "But". Who is speaking? Who addresses the woman as Princess who is made - not born: God, the royal father, a lover, the father of her child? Another poem entitled "Gynae I" about post-partum complications precedes "For Kynna II" and answers these questions. Here are some excerpts:

[]$^{57}$

Getting scraped

Lying in

'vestigating only.

Post-partum complications:

Tying it up

Throwing one out

Removing it all.

Dying for it

Dying with it

Dying from it.

[ ]

All agony

no

ecstasy.

[ ]

For,

he

comes and stands with

a sheepish grin that

tries to hide the

scowl and

fails.

[...]

There

she lies

the lamb.

Rounded limbs;

dimpled cheeks;

dewy lips

parted

57 Aidoo, Ama Ata. „Gynae I“. The Heinemann Book of African Women's Poetry. Eds. Stella and Frank Chipasula. London: Heinemann, 1995. 43. 


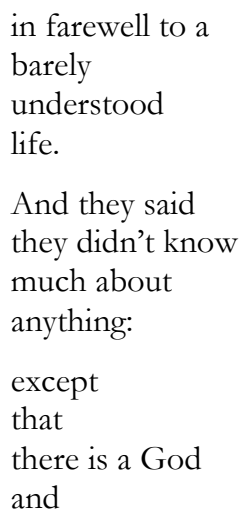

$\mathrm{He}$ is a man.

This man, this God, confronts her with her lost heritage, the destruction of the land - summarised in the unforgettable image of the UN-protofarm - and his own dejection. The first part violently ends with the death of a man who is not willing to accept the situation. The second part begins like a nostalgic return to a pastoral past, "Ah, this land is truly beautiful." But again politics and sarcastic comments intrude, "Cows might even smile - at milking." Africans and even their animals seem to agree happily to their exploitation and starvation. With the address of the daughter, the poem now turns to the personal. The exclamation, "Baby, it couldn't have been you that I feared," expresses the mother's endearment and perhaps also her anguish for her child's future. This third section shows the turmoil of a confused mind. "The noises, the praises, the blame" and the hectic of the activities, "running", "rising", "rocketing", are set against "the still winds" and "a time that has not begun to get restless" in the preceding part. They refer to the hectic activities and the atmosphere in the labour-room in "Gynae I" and to the love "pawed by // rising expectations and rocketing inflations" in "For Kinna II". The next step takes up the expectations and inflations concerning possibilities of life ranging between the extremes of omnipotence and desperation. The poem culminates in the courageous contradiction of a pre-determined life and in the assertion of hope for a future built on choices. The mother lovingly greets and accepts her daughter as "My Little Queen". The child is born a queen and will now govern her mother's life.

\section{Stella P. Chipasula}

Stella P. Chipasula is co-editor of The Heinemann Book of African Women's Poetry together with her husband Frank Chipasula. Both are descended from Malawi. This small East-African state, the former British protectorate Njassaland, has found itd own peaceful way to independence in 1964. It has developed stable 
political and economic conditions. It is famous for its friendly population and its beautiful landscape.

Stella P. Chipasula is a teacher, received a BA in Art History, worked on Malawian folktales and has written some poems. She works with her husband at the University of Nebraska at Omaha. She is represented with two of her poems in the anthology. One poem deals with the mother-daughter relationship, "I'm My Own Mother Now", the other poem is written for the birth of her daughter.

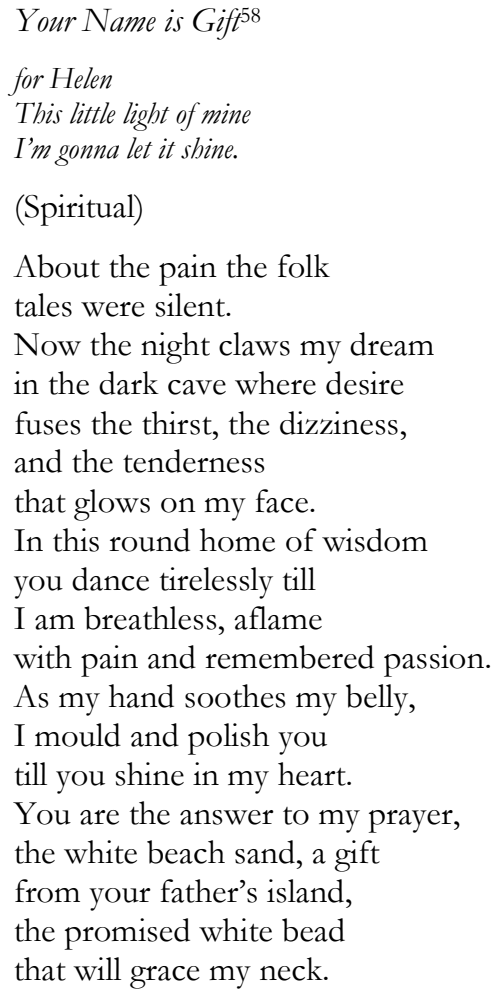

25 April 1989

This poem takes its theme from a spiritual and is written like a song of praise. The poetic language works with alliteration and images. This song makes audible what has been silenced in folk songs so far: the pain of labour but also the remembrance of passion. It includes the father and expresses gratitude, promise and hope.

After Ama Ata Aiddoo's rather disturbing modernist poem, this quiet poem in traditional form concludes the circle of women's poems for their daughters.

\footnotetext{
58 Chipasula, Stella. "Your Name is Gift." The Heinemann Book of African Women's Poetry. Eds. Stella and Frank Chipasula. London: Heinemann, 1995. 132.
} 


\title{
Kofi Awoonor
}

"Remember the Christmas / when on our way from Chelsea / you fell on the pavements / broke a tooth / and I was mute?"

Kofi Awoonor was born in Ghana in 1935. He is a poet, novelist, critic, academic and politician. He was educated in Ghana, the United Kingdom and the United States. Closely connected with the first president of Ghana, Nkame Krumah, Awoonor was forced to go into exile after a coup against Nkrumah in 1966. During the time abroad, he completed his graduate and doctoral studies. For several years, he taught English Literature at the State University of New York. In the last years, he engaged in political activities. From 1990 until 1994, he was Ghana's Permanent Representative and Ambassador to the United Nations in New York.

The poet Awoonor is conscious of his roots in traditional poetry and folk songs. His grandmother was a mourning singer. He uses this motif in several of his poems to express the grief of the Western-educated African looking back at his native culture. Awoonor has published several collections of poetry and two novels. In his fiction and poetry, the author often works on two levels. The first level is usually a narrative of everyday experience. The second level is a symbolic journey through a personal or political development filled with Biblical and literary allusions. The poet applies this technique to his poem "To Sika" for his daughter.

\section{To Sika $a^{59}$}

\author{
Remember the Christmas \\ when on our way from Chelsea \\ you fell on pavements \\ broke a tooth and I was mute? \\ Your mother thought I was cruel, \\ but your fall hurt me \\ in that all of us, \\ your clansmen, fell on alien ground, \\ Remember the morning walks \\ to your nanny's \\ where you sulked and longed for home \\ the agony of flights and \\ the pain of separation looming \\ large like winter moons. \\ I knew I was the tempest \\ that will blast your youth \\ and misery of infancy. \\ Oh, I was the Abraham \\ sacrificing my Isaac \\ waiting in vain for the ram in the thicket
}

${ }^{59}$ Awoonor, Kofi. “To Sika." A Selection of African Poetry. Eds. Kojo Senanu and Theo Vincent. Burnt Mill, Harlow, Essex: Longman, 1976. 155-156. 


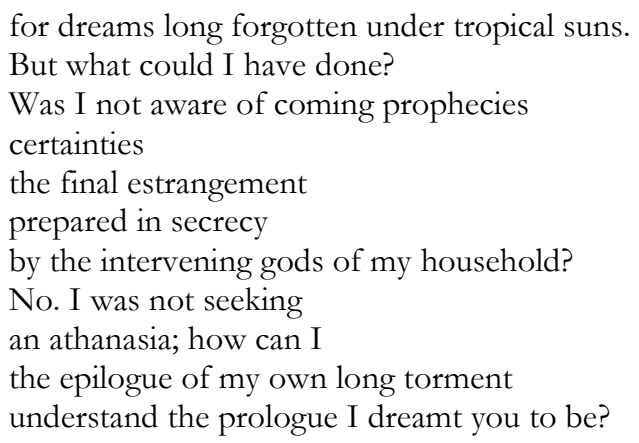

This poem contains three parts. A triplet at the centre presents the poem's concern: "I knew I was the tempest that will blast your youth and misery of infancy." The first and the third part of the poem consist of fourteen lines. The structure of the poem is a variation on the fourteen-line sonnet and alludes to the tradition of sonnets as expression of love. Sika is usually a girl's name which means gold or something highly appreciated. In this poem, small accidents and events of his daughter's life are placed side by side with the father's meditations on his faith and his fate that has called him to be a poet. The speaker of the poem had been unable to speak immediately to his child when it had been necessary. Now he is anxious to reassure the child of his tenderness and care by showing her that he recollects every detail of her life: her broken tooth, her sullen mood, her fear of imminent separation. The first part addresses the child two times, "Remember the Christmas...", "Remember the morning walks...." The daughter's accident and the separation of father and daughter are connected with the failure of protection by ancestral spirits and a Christian God. African spirits should protect the members of a clan when they are abroad, but "all of us, your clansmen fell on alien ground." In the Old Testament, the appearance of the substitute ram counteracts Isaac's sacrifice. Here, however, the father has to sacrifice his daughter's happy childhood to his vocation as a poet. The central and the second part lament the father's guilt and try to explain his apparent indifference and cruelty, "Oh, I was the Abraham sacrificing his Isaac". The references to Christian religion and to "prophecies" and "certainties" from the gods of the household point to a change of faith. The term "athanasia" means creed, belief. The father meditates on the question of "fate" that has called him to be a poet. The return to ancient African gods and his daughter's presence enable the poet to move on after having been uncertain of his role as a singer for a long time. Sika is the inspiration for his poem. The child's life lights and fuels the father's creativity. Finally, the poet as father is able to make a poem about his silence under which he had been hiding his tenderness.

Whereas women's poems dedicated to daughters express their concern for body and mind of both mothers and children, there is only a short allusion to the body in the father's poem, "the broken tooth." A comparison of the four poems for daughters demonstrates that Micere Githae Mugo's and Ama Ata Aidoo's 
poems clearly transcend the personal sphere and develop a political message. The first is concerned with the matrilineal heritage, the second with changes and new options for women. The poems by Stella P. Chipasula and Kofi Awonor foreground the intimacy and privacy of the child-parent relationship. Kofi Awoonor shows that fathering is filled with tenderness, responsibility and care, even though it is hidden under silence and subsequently expressed in a highly artistic poem.

The last section of poetry by African writers moves to the unique female experience of childbearing, giving birth and nursing. These biological facts of mothering still remain a universal experience of women. Neither advanced reproductive technology nor postmodernist linguistic turns have managed to assail it up to now.

\section{Jeni Couzyn}

Jeni Couzyn, born 1942, is a white South African. In her home country, she taught at black schools and fought against Apartheid. She lives and works as psychotherapist in London. She divides her time between Britain, South Africa and her adopted country Canada. She is director of the Bethesda Arts Centre in South Africa and performs at literary festivals in all these countries where she has initiated successful open poetry readings. She has published fifteen books, including two books for children. She is editor of three anthologies, among them The Bloodaxe Book of Contemporary Women Poets (1985), which has become a set text at schools and universities. Her cycle of poems, A Time to be Born (1983), deals with childbirth from the conception to birth and early infancy.

The poetic work of a minimalist artist like Jeni Couzyn offers knowledge and experience in concentrated form. Her poems are deceptively simple, short, unrhymed. This poetry seems playful and effortless. Only a close analysis reveals its craftsmanship.

$$
\begin{aligned}
& \text { The Mystery }{ }^{60} \\
& \text { First I am one } \\
& \text { then I am two } \\
& \text { then I am one again } \\
& \text { joined to she was part of me } \\
& \text { my love. } \\
& \text { I am I } \\
& \text { I am I and thee } \\
& \text { I am I and she was who was } \\
& \text { I and thee } \\
& \text { who kicks and strains in my belly }
\end{aligned}
$$

${ }^{60}$ Couzyn, Jeni. ,"The Mystery“. The Heinemann Book of African Women's Poetry.Eds. Stella and Frank Chipasula. London: Heinemann, 1995. 172. 


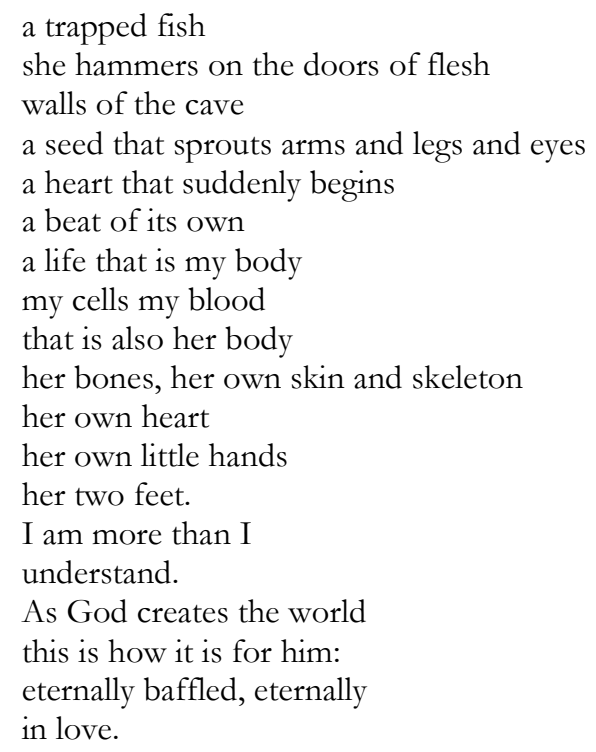

This poem speaks enigmatically about pregnancy and childbirth. In the first eight lines, the first person speaker describes the mysterious experience of pregnancy. The pronoun " $\mathrm{I}$ " is used ten times. The repetition and enumeration emphasise the astonishment expressed in the summary: "I am more than I understand." There is also a faintly biblical allusion in the use of "thee". These first eight lines and the poem's last six lines allude with their division into an octet and a sextet to an embedded sonnet form and to the tradition of the sonnet as expression of human and divine love. This "separated" sonnet embraces or forms the womb for the second part of the poem that describes how the embryo develops into a foetus and finally into an individual child. This part also consists of fourteen lines. The procreation and creation of a human being remains an enigmatic experience and is compared to God's creation of the world. Both are acts of love.

Heartsong 61

I heard your heartbeat.

It flew out into the room, a startled bird

whirring high and wild.

I stopped breathing to listen

so high and fast it would surely race itself

down and fall

\footnotetext{
${ }^{61}$ Couzyn, Jeni. "Heartsong”. The Heinemann Book of African Women's Poetry. Eds. Stella and Frank
} Chipasula. London: Heinemann, 1995. 173. 
but it held strong, light

vibrant beside the slow deep booming

my old heart suddenly audible.

Out of the union that holds us separate

you've sent me a sound like a name.

Now I know you'll be born.

In most of their poems about pregnancy, women poets describe the first kicking of their babies as an exciting moment. In her poem "Heartsong", however, Jeni Couzyn composes a song out of the heartbeats of mother and baby. The poem consists of three unrhymed triplets. In the first three triplets, the second line is always longer than the first and the third. These run-on lines bear five stresses, e.g. one or two more than the other lines, and they accelerate the speed. They represent the baby's heartbeat that is faster than that of the mother. Now the mother can listen to her own and her baby's heartbeat for a short moment only. The baby's heartbeat resembles rather a vibration whereas the heartbeat of the adult can be heard as a slow booming. The poem exactly describes the influence of the mother's breathing, of her inspiration and expiration, on these two different rhythms of the heart, which fuse into one in the end. A surprising and exciting experience of pregnancy is perfectly set into the music of poetic language.

\section{Kristina Rungano}

Kristina Rungano was born in Harare/Zimbabwe in 1963. In her home town, she attended Catholic-run boarding schools. In Britain, she obtained a diploma in Computer Science. She lives and works in Britain as a Senior Lecturer of Business Information Management at Canterbury Christ University at Canterbury. She was the first published woman poet in Zimbabwe. A Storm of Brewing (1985) is her first and only collection of poetry so far. In her poems, she uses a variety of personae to trace aspects of women's experience or to deal with the impact of war.

\section{Labour ${ }^{62}$}

For nine months I had borne him in my womb.

Nine months of disillusionment and pain

Relieved only occasionally by the gentle kicking within me;

The gentle movement of the life I created within me

Nine months I waited for this day;

Nine months and the grotesque lump growing on me.

And Kit making numerous sacrifices - of patience and love -

Nine dreary months of waiting for this day.

${ }^{62}$ Rungano, Christina. „Labour”. The Heinemann Book of African Women's Poetry. Eds. Stella and Frank Chipasula. London: Heinemann, 1995. 209. 
And now I was beginning to feel sharp pains in me -

And mama saying they are labour pains -

The pains which will be the spring of new life...

Would it be a boy, I thought with intensified wonder,

- How proud his father would be,

- Or would it be a girl -

Someone I could teach to be just like me

And spoil with pretty frocks

And sweetly scented flowers to adorn her head?

I looked up into Kit's eyes

- The eyes that had seen me through

- The eyes that had known my sadness and joy for nine months

And I saw in them all love and care

- The pain which he felt for me

And like the sun on a cold morning

Relieved me of all fright, all desolation.

I looked with warm contemplation

To the moment when his warm embrace would say

'Our own baby - the very essence of our love

And tiny little hands would cling to my breasts in hunger

Tiny mouth drawing warm milk from me

An innocent little face looking into my face.

With trust

Learning me, just as Kit did.

I felt him, Kit

Captured by a foresight of summer days to come

The days when we - no longer just two -

Would walk in the dusk

Caressed by the warm breeze

And our child would learn to sing the birds to sleep

And dance the kan-kan with the fireflies.

And thus I was borne to the labour ward

Whilst Kit waited

- Waited again

- Waited in warm anticipation

- Waited for the awakening of my new beginning.

The poem "Labour" has a clear pattern of six stanzas comprising five to nine lines. The sixth stanza is the shortest with five lines. The shape of the poem creates the impression of a slow progress that speeds up the pace in the end. Further, the end of every line in the first stanza and the first part of the second stanza end with a pause. There are no run-on lines. All sentences are coming to an end. The poet uses different linguistic tools to slow the rhythm down: the sentences terminate in parts set in parenthesis or reach dashes. The poem's first part describes the 
inconveniences of pregnancy until the beginning of labour-pains, "The pains which will be the spring of new life...." This moment is indicated by a different spacing and a modified syntax. The poet uses run-on lines and questions expressing the changed mood of the woman, who now directs her thoughts towards the future, anticipates her child and an idyllic family life. Written in the 1980s, this narrative poem is outstanding in its content for two reasons: it reveals a woman's ambivalence towards the changes in her body and her mood during pregnancy, and it includes the man, the child's father whose love helped her through all these inconveniences: "For nine months I waited for this day; / Nine months and the grotesque lump growing on me." Nine dreary months of waiting for this day." And on the other side: "And Kit making numerous sacrifices - of patience and love;" "I looked up into Kit's eyes [...] And saw in them all love and care."

With the second wave of feminism in the 1960s, women poets began to question and ridicule clichés and stereotypes of the exaggerated cult of motherhood. The American poet Sylvia Plath, whose poem "Purdah" I analysed in a preceding chapter, wrote about the disadvantages of pregnancy and motherhood in her poems "Morning Song" and "Metaphors". In her poem "Metaphors"63, for example, Plath compared the pregnant woman to an "elephant" and a "ponderous house" alluding to the clumsiness and heaviness of the body. The poet also pointed at the sometimes schizoid feelings of the pregnant woman. Pregnancy depersonalises the woman: the foetus exploits her in a way that she is confused and reverses the roles, "I'm a cow in a calf." In the poem "Labour", the speaker presents her sense of her body and her mood without any further details. From medical experience, many complications during pregnancy come to mind: hypertension, renal failure, oedema, depression, psychosis etc. Modern pre-natal medicine relieves many fears about the health of the unborn child that overshadowed pregnancies in former times. Contemporary medical care tries to include the fathers into the experience of pregnancy: they are invited to participate in courses that prepare for the delivery; they are allowed to accompany and attend their wives during childbirth. These changes attempt to unite women and men in their responsibility of parenthood. This poem points to these changes in a personal and intimate form. The next poem presents the experience of childbirth from a male point of view.

\section{Lenrie Peters}

"Love, lustreless word / A thousand times misused / As often bathed in blood."

Lenrie Peters was born in Gambia in 1932. He is a surgeon, poet, novelist and singer. He was educated at the universities of Cambridge and London where he

${ }^{63}$ Plath, Sylvia. "Metaphors". An Introduction to Literature. Eleventh Edition. Ed. Sylvan Barnet, et al. New York: Longman, 1997. 555. 
qualified as a surgeon in 1959. He has practised in England, Sierra Leone and since 1969 in his native Gambia. Many of his poems point to his experience as a physician.

She came in silken drapes ${ }^{64}$

She came in silken drapes

and naked breasts,

Veiled Artemis; seated

On an eagle's nest

Brandishing the sword

and that forbidden thing

Less clumsy in a dream

She handed me the word

Sealed in cotton wool

Tied in an endless riddle

Love and loveless hate

Poison of the coral snake

Infinitely tender to see

Like Saturn's mystery.

Gentle winged butterfly

with the voiceless cry by day -

Huntress of crippled manhood

Unequal tyrant by night

Visiting the caves of Hysterus

Where the wounded leopard sleeps

In the green light of peace.

Walking in the mist

Among the chambered Monuments

Crowded like icicles

In the patient current

Which feeds by exhaustion,

She smoothes her wrinkles

And prepares for the assault.

Love, lustreless word

A thousand times misused

As often bathed in blood.

Let me wash you

Like the frenzied gold-sifter

Let me lead you

through the dense crowd

over the phallic mound

To the crystal spring

${ }^{64}$ Peters, Lenrie. „She came in silken drapes”. A Selection of African Poetry. Eds. Kojo Senanu and Theo Vincent. Burnt Mill, Harlow, Essex: Longman, 1976. 110-111. 
Where I have found

the purest living thing.

The poem "She came in silken drapes" consists of five stanzas comprising seven lines except for the fourth stanza. This stanza catches the eye because it is longer with its ten lines. It contains the poem's central statement: "Love, lustreless word / A thousand times misused / As often bathed in blood." This message is introduced like an attack: "She smoothes her wrinkles / And prepares for the assault." This poem uses the childbirth metaphor to develop simultaneously the birth of a child and a poem. Both the child and the poem are outcomes of a highly ambivalent and violent love affair between a man and a woman, a poet and his muse. The poet creates a poetic voice, using alliteration, assonance and some rhymes. But most of all, the poem develops its tension through the swift change of symbols and images from the Bible and from Greek and Roman mythology. At the same time, most of these images have a central place in psychoanalytic thought about male and female sexuality.

The first stanza describes a female figure: she is both a seductive woman and the Greek goddess Artemis who was associated with fertility, childbirth, growth of the field and life of animals. She is "brandishing the sword". Her activity is directed against Saturn, the Roman god of agriculture, who appears in the second stanza. According to classical legend, he always devoured his sons as soon as they were born. In the second and third stanza, the new-born child is addressed as "word" and as "gentle winged butterfly". The first allusion is Biblical. The gospel John I, 14 maintains: "The word became flesh and dwelt among us!" The Christian tradition is based on a male god and his son: "In the beginning was the Word, and the Word was with God, and the Word was God. The same was in the beginning with God. All things were made by Him; and without Him was not anything that was made." In Jewish, Christian, Islamic traditions, God the Father created ancient Goddesses as Mothers, such as Artemis, Isis, Demeter, who represented procreation. The poet changes Christian tradition and returns to the mythical Goddess whom he invests with the power of the word. The figure of the woman represents, however, also the threat of castration and violence: "Huntress of crippled manhood / unequal tyrant at night / Visiting the caves of Hysterus." The use of psychoanalytic analogies intensifies the impression of conflicts and disillusionment in male/female relationship. Love is no longer an exceptional feeling but it has lost its "lustre" - its radiance and beauty. "Love", "the word", "the child" "are often bathed in blood." The physician has assisted at many deliveries and knows that childbirth can be an extremely bloody process and sight. The poet knows that many wars have been fought for love's sake. The Trojan War from Greek mythology is only one example. While the poet charges the first four stanzas with complex images and symbols, he is directly speaking to the woman or muse in the last stanza. He seems to feel unable to continue this way. This is evident in the shorter lines and plain language. The speaker of the poem compares himself to 
"the frenzied gold-sifter" who offers "to wash" his object of desire and to "lead her to the crystal spring". The new-born child must be washed. This poem is polished after its first delivery on the page in order to invest it with lustre. After a painful birthing process and an almost frantic wrestling with words "that forbidden thing / Less clumsy in a dream" from the beginning can be admired and celebrated as the "purest living thing". The poem must be freed from all superfluous ballast. The "frenzied gold-sifter" leaves dead pure gold behind and advances to the deceptive simplicity of nature. After this fusion of biological and literary childbirth that connects body and mind, experience and aesthetics, the poet remains baffled in admiration of the mysteries of life and nature. He cannot grasp them with words: they remain "the thing". Perhaps this is also an ironic or self-ironic comment on his struggle. But I am careful with these judgements because it is difficult to deal with humour and irony cross-culturally.

The visual quality of Lenrie Peters' poem reminded me of Laura Mulvey's essay "Visual pleasure and narrative cinema" (1975). She uses psychoanalysis as a political weapon in her discussion of cinematic codes. According to Mulvey, the cinematic images of women have so far represented male fantasies and obsessions. The act of looking, the "male gaze", at women consists of a voyeuristic or eroticised and a narcissistic part, which produces pleasure through identification. Mulvey criticises both the voyeurism and the fetishism and develops feminist alternatives. My work shows these alternatives in women's poetry. In their poems, women write about their own experience. They insist on women's own selfperception and subvert the power structure of the gaze.

Referring to the complexity of this poem, the editors of the study book $A S_{e}$ lection of African Poetry accompany this poem with the question: "Do you think this poem is a successful poem? Give reasons for your answer." (Senanu and Vincent 1976, 112). I disliked this poem at first because of its profuse imagery and symbolism. It is, however, an intriguing poem that conjures up the mystery and the difficulty of procreation and creation and does not impose a simple answer. The childbirth metaphor is, indeed, an intricate subject matter. In her essay "Creativity and the Childbirth Metaphor: Gender Difference in Literary Discourse" (1987), Susan Stanford Friedman explores the cultural resonance of the childbirth metaphor and gender difference in the metaphor's meaning reflected in the process of reading and writing:

The context of the childbirth metaphor is the institution of motherhood in the culture at large. Consequently, the meaning of the childbirth metaphor is overdetermined by psychological and ideological resonance evoked by, but independent of, the text. [...] While the metaphor draws together mind and body, word and womb, it also evokes the sexual division of labour upon which western patriarchy is founded. [...] For biological and historical reasons, childbirth is an event whose meaning is constituted differently by women and men. This difference informs why they use it and what they use it for. Men's use of the metaphor begins in distance from and attraction to the Other. [...]. Gershon Legman applies this theory specifi- 
cally to the male birth metaphor, which he calls a 'male motherhood of authorship,' an archetypal fantasy of great power and persistence determined by largely unconscious fear and envy of woman's sexual and reproductive powers. [...] The childbirth metaphors of women and men differ not only in their psychological charge but also in their function within the larger work. While men's metaphors often reflect the ethos of their times, women's metaphors tend to be deeply personal statements about how they try to resolve their conflict with cultural prescriptions. (Friedman 1987, 51-66)

According to Friedman's research, the meaning and evaluation of the childbirth metaphor changed from the Enlightenment to the Romantic era:

Satirists like Pope and Dryden associated the human birth process with 'deformed poetic productivity' and regularly deflected it onto the enemy poet. The bad poet was above all a 'begetter' who breeds out his own distempered 'offspring' because his lack of reason makes him like 'the one who gives birth, who conceives and brings forth, [who] is nowhere in control, but rather is subject to a purely spontaneous animal function.' [...] The Romantics repeatedly used the metaphor not to condemn their enemies but to define the production of art as 'a spontaneous process independent of intention, precept or even consciousness.' [...] This shift from repulsion to idealisation parallels a historical evolution in the representation of women. [...] The Romantic period's embrace of intuition, emotion, and organicism - all qualities associated with the feminine - transformed the birth metaphor into something positive. But [...] both the positive and negative manifestations of the male metaphor perpetuate the mind-body split it attempts to transcend through analogy. Both therefore reaffirm creativity as the province of men and procreativity as the primary destiny of women. (1987, 64-65)

I have quoted this at length to emphasise the point that women's poems defy those divisions and unite body and word, heart and mind. Male writers ought to listen attentively to the next two women poets. If we changed the title of Irène Assiba d'Almeida's poem "Sister, You Cannot Think a Baby Out" into "Brother, for you it is impossible to think a baby out," it would self-consciously reflect the real situation. By using various symbols and images, the poem "She came in silken drapes" tries to equate the laborious task of writing a poem with childbirth. Yet, a poem is not a baby.

\section{Irène Assiba d'Almeida}

Irène Assiba d'Almeida was born in Benin, the former French colony of Dahome. It is a small country at the West-African coast. After its independence from France in 1960, the country experienced long periods of political and economic instability. From 1974-1990, Benin was ruled by a marxist-leninist government. In 1990, the country returned to democracy. Benin's national and literary language is French. Irène Assiba d'Almeida writes in both languages. She studied in her home 
country, Nigeria, France and the United States. She collaborated on translations from African writers into French and on critical studies. She teaches at the University of Arizona, Phoenix. Her most recent publication Francophone African Women Writers: Destroying the Emptiness of Silence (2001) is the first single-author critical study in English on the work of Francophone African women writers. It is concerned with texts that look at women and family, break sexual taboos and deal with the problem of compulsory motherhood.

Sister, You Cannot Think a Baby Out! 65

Day after day

Week after week

Month after month

Life within me

I, amazed to feel it grow

Unable to comprehend

the mystery

I, afraid of pain

Not like anything I know

Is knowledge power?

Is ignorance bliss?

The first kick, energetic,

Pleasant, moving pain.

Will the rest be the same?

An old Lamaze book

On a dusty shelf

Breathe in, breathe out,

Breathe life.

Sisters laughing at you

At Lamaze too

At all the books you read!

When pain tightly grips

And Queen Nature reigns powerful,

Who remembers?

Sister, you cannot think a baby out!

Giant octopus

Tentacles in disarray

My body knows not

How to channel the pain.

A lull at last

Soothing balm on a raw wound

Then, suddenly, a dam gives way

${ }^{65}$ d'Almeida Irène Assiba. "Sister, You Cannot Think a Baby Out!" The Heinemann Book of African Women's Poetry. Eds. Stella and Frank Chipasula. London: Heinemann, 1995. 41-42. 
The water breaks.

Surprised at the mighty flow

I lie, soaked in pain and fear.

An iron hand grips my womb

And viciously lets go

grips, lets go,

Again and again

Faster and faster

Sweating pearls all over my brown skin

Eyes wide open in disbelief

Never knew I could be

such a good contortionist!

Exhausted

I muster my energies

Like a volcano

Erupting a living force!

A last pang, excruciating

And, before I know

A thunderlike scream goes

As comes into this world

The baby

With the joyous scream of life.

Yes, I know

You cannot think a baby out!

This poem consists of two parts of almost the same length: the first part has 24, the second part 29 lines. Both parts are separated by the repetition of the title. The first part describes the pregnancy and the preparation for birthing. The second part depicts the real event of the delivery. The poem's structure reflects how the experience of birthing contradicts all expectations and speculations. Working with different style, imagery and language in both parts, the poem translates abstract ideas of pain into the experience of physical pain. The narrative has a linear structure. The author uses different poetic tools to connect the parts of the poem. The poet is consciously linking sounds, for example, the rhymes "grow" and "know" in line five and nine that connect the intricate and split sentence, "I, amazed to feel it grow / [...] Not like anything I know." There are groupings of details in threes, for example, "Breathe in, breath out, / Breathe life" in the first part, which is set against "lets go, grips, lets go," in the second part. Additionally, the poem works with the repetition of unconventional sentence structures which express ignorance, surprise and ironic comment. In the first part, we find, "I, amazed to feel it grow / Unable to comprehend / the mystery / I, afraid of pain / Not like anything I know." In the second part, the reader is confronted with a converted sentence structure that reflects the content and the ironic commentary, "Never 
knew I could be / such a good contortionist!" Another poetic tool is the contrasting content of similarly shaped parts, for example, in part one, we listen to the tranquil flow of the four-liner, "An old Lamaze book / On a dusty shelf / Breathe in, breathe out, / Breathe life." the corresponding four-liner in part two, however, shows another experience of labour-pains, "Exhausted / I muster my energies / Like a volcano / Erupting a living force!" Both parts of the poem affirm the questions that are asked at the end of the first stanza, "Is knowledge power? / Is ignorance bliss?" This poem translates "the ignorance of bliss into the power of knowledge." A woman's poem contradicts the preceding poem of a man with its self-conscious statement, "Sister, You cannot Think a Baby Out! - Brother, for You it is totally impossible!" Jeni Couzyn's poem "Spell for Birth" concludes our circle of women's poems on mothering.

Spell for Birth ${ }^{66}$

God the mother

God the daughter

God the holy spirit

Triune of love

Triune of grace

Stream take you

Current aid you

Earth receive you

God the mother

God the daughter

God the holy spirit

Triune of grace

Triune of power.

The poem "Spell for Birth" converts the Trinity of Christianity into a female one. This poem returns to the pre-Christian goddess who symbolises fertility, sexuality and power. It realises a crucial issue of black female aesthetics because it goes back to African myth. God the father; God the son and God the holy spirit become "God the mother, god the daughter and god the holy spirit" for a birthing spell. This is a powerful feminist appropriation of Christian religion for the universal female experience of birthing. The poem applies the image of Trinity two times - "Mother, daughter, holy spirit", "stream, current, earth". This spirit represents the bond between God and human being and between mother and daughter. My analysis of the poem is based on the different meanings of the word "spell": first, it can stand for a turn of work to be taken, a period of anything experienced; second, for a charm, to word off danger; third for a word or phrase supposed to

${ }^{66}$ Couzyn, Jeni. "Spell for Birth". The Heinemann Book of African Women's Poetry. Eds. Stella and Frank Chipasula. London: Heinemann, 1995. 172. 
have magic power. For the second triune - "stream", "current", "earth" - two meanings come into question. First, it could describe the process of birthing: the stream of fruit water surrounds the child, forced out of her mother's womb, she takes her first breath on earth. Second, it could stand for an imploration of the elements of water, air and earth that are vital for human life. Used as a verbal charm, this spell shall ward off danger - trouble and tribulation in labour, and in a broader sense - menace of human life. In "Spell for birth", the third, and most important, Trinity is incomplete. "Triune" of "love" and "grace" and "triune" of "grace" and "power" are still separated. Is this spell an incantation, or rather an imploration, for the birth of the third triune, the "Trinity of love, grace and power", that our world needs so desperately? 


\section{Outlook}

What was my point of putting together these contested issues of feminism: difference of gender, race, ethnicity as constituted by feminist theory and women's poetry on mothering from Anglophone postcolonial contexts?

First, this study presents English poetry by women from India, the Caribbean and Africa, that has been neglected by scholarly literary criticism so far. I have used these poems as cultural, political and ethical repertories in the sense of "cultural memory", "communal self-image" and as a fluid anthology of individual responses.

Second, my study wants to examine the influence of critical positions from postcolonialism, postmodernism, poststructuralism and deconstruction on feminist theory and politics. I wanted to draw attention to the fact that feminism not only constitutes an academic discourse, but has also created a social and cultural movement with wide-ranging impact on twentieth century societies. It is regarded as one of the most important strengths of feminism that feminist theory and politics actively engage with each other enriching both. In the recent history of feminism, however, this advantage has been challenged. Feminist politics includes groups from the margin. Simultaneously, feminist theory incorporates critical positions from postcolonialism, postmodernism, poststructuralism. Concerning feminism's issues of gender, race and ethnicity, the new critical positions open space for new meanings and values and overcome an argumentation that is based on binary oppositions and on apparently essential truth values. They offer new perspectives on issues of sexism, racism and ethnocentrism and provide insight into the possibilities of change. These advantages should be defended against some radical feminists who criticise the emphasis on differences and postmodernism's supposed inability of political commitment. The question is not to abandon theory but to bridge the gap between feminist theory and feminist practice. As an answer to this dilemma, feminism began to foreground the aspect of women's common experience and put the communicative bond between women from 
different cultures as the basis for politics on the political agenda. The attention was, however, usually directed at women's oppression and problems of women's "identity". My study questions this evaluation of women's social position. Women's poetry on mothering develops a social self out of the intimate motherchild relationship. My study regards this poetry as one means of breaking down barriers because it is at the same time art, ethics and politics. It supports Spivak's subtle acknowledgement: "To theorize the political, to politicize the theoretical are such vast aggregative asymmetrical undertakings; the hardest lesson is the impossible intimacy of the ethical" (Butler and Scott 1992, 81).

The terms "mothering" and "women's writing" are, however, hotly contested by feminism. The term "mothering" seems to imply a sex-specific essentialism. But the ambivalence of a term does not justify its abolition. I deliberately maintain its use as a metaphorical comprehension that encompasses the more precise and not sex-specific concepts of care-taking, nurturing and social parenthood which include men into the care-taking community. I do by no means regard this "womanist" stance as a backlash position for feminism. I will not do away with problems of women's "identity" and women's oppression by foregrounding a general social reputation of the mother-child relation. But I want to go beyond identity politics that circle around patriarchy, the system of male oppression, and women's role as victims. My study shows how a social self develops out of communication and common goals. This does not imply a universal capacity of women for mutual connections or a privileged affinity between women and peace or women and nature. But it is a concept that has proved its usefulness in crisis areas and poor living conditions. Shared responsibilities based on "maternal thinking", "maternal practice" and "shared parenthood" can pave the ground for women's solidarity and peace politics. The questionable term "women's poetry" seems to regard women writers as a category. By introducing the concept of Friedman's "locational feminism", I want to call attention to the fact that the immediate contexts for women who write in English cannot be gathered into the same field. My study takes the respective race/class subject position, the political association and the aesthetical interests of the diverse women writers into consideration.

Third, my study situates my readings of particular poetry in contrast to, in dialogue with and as a supplement to critical theory. In this way, it wants to parry a critique that Gayatri Chakravorti Spivak called "the reproduction of cultural imperialism" as western feminism "discovers" and appropriates "the Third World":

To consider the Third World as distant cultures, exploited but with rich intact literary heritages waiting to be recovered, interpreted, and curricularized in English translation fosters the emergence of 'the Third World' as a signifier that allows us to forget the 'worlding', even as it expands the empire of the literary discipline. (Warhol and Herndl 1997, 896) 
This critique calls for a serious theoretical scrutiny of the deeper political commitments that govern the teaching of literature. It also implies that other cultural traditions provide different approaches to the nature and function of art.

What I have arrived at present, is first the collection, presentation and analysis of sixty-three poems written by twenty Anglophone women and three men that had been ignored so far. I decided to print the texts in total in order to make the reader familiar with them. A short digression may be allowed. A striking imbalance exists in the availability of poetry books and books on theory. Whereas our net of university libraries provides hundreds of books on theory, the choice of poetry is really small. I asked myself whether this emphasis on theory is a national German feature or a global development. This could be an issue for further investigations. As a comparison and also as a support of my study, I include some information about the market for poetry in India. In Modern English Poetry in India Revised Edition (2004), Bruce King writes:

Although Indian writers complain that there is no readership for poetry in English the sales compare favourably with poetry published in the regional languages and also with poetry in other English-speaking countries. [...] The university market is also still small for poets. [ ] Only a fifth to a quarter of Indian universities offer courses in Indian English writing; novels are set texts far more often than poetry. A more detailed examination of set texts would reveal a surprising conservatism Aurobindo, Toru Dutt, Sarojini Naidu and even Tagore are often the main poets studied. [ ] The situation will change as more dissertations are written on English literature. [ ] While it is pleasing to see that a growing number of English departments teach modern Indian poetry, until more give courses at both the BA and the MA levels, a profitable market for Indian poetry is unlikely to develop. Such a university market is needed if Indian poetry is to be self-sustaining and no longer dependent on a few enterprising publishers and sympathetic journals. (2004, 54-55)

Regarding the difficult access to poetry, I take their totally reprinted presentations to be indispensable. In good poetry, it is each empty space, each word, each line, each punctuation mark, in short, every detail that counts. My small collection of poems already demonstrates that these writers from postcolonial contexts have enriched the traditional poetic English language. This poetry blends Indian, Caribbean and African oral traditions with poetic forms from Europe and America. Additionally, this poetry works with elements of popular culture and reaches a larger audience as performance poetry. Poetry plays the role of a go-between on many levels. Further studies on poetry should be equipped with more primary literature - anthologies and single editions of poets, in order to detect still more aspects.

What I have achieved is second to show that contemporary English poetry by women from postcolonial contexts deals with the differences of gender, race and ethnicity. The poems analysed here stay in dialogue with and in contrast to critical theory. They are far more than a supplement because they direct towards practice. 
In my theoretical considerations on gender difference, I develop the different historical steps from biological explanation to the discursive/cultural concept of post-structuralism that questions the biological basis of the sex/gender difference. Women's poetry on mothering, however, directs our attention to the fact that gender/sex still plays an important role in the hierarchy and the struggle for power in the relationships between women and men. Women's bodies continue to be targets of oppression. Olive Senior's poems, "The Mother" and "One Night, the Father", speak about and struggle against rape and sexual abuse within the family. Her poems take a "womanist" stance. They include the fathers and show that the economic conditions contribute to what happens in the families. Eunice de Souza's poem "Catholic Mother" denounces forms of motherhood as enforced by certain groups in the Catholic Church. I have outlined how the cultural concept of gender shaped feminism's ideas of motherhood. Feminist literary criticism and aesthetics demonstrated how the introduction of biology reduced women to the procreative role. The symbolic use of motherhood excluded the actual experience of women. The different use of the childbirth metaphor by women and men is a convincing example of gender difference. The male voice in Lenrie Peters' poem "She came in silken drapes" expresses the separation between creativity and procreativity. Women's poems, however, unite body and spirit. Jeni Couzyn's poems "The Mystery" and "Heartsong", Kristina Rungano's poem "Labour", Irène Assiba d'Almeda's poem "Sister, You Cannot Think a Baby Out!" show how the experience of pregnancy and birthing changes a woman's life and the relationship between parents. They overcome the depiction of women as victims of their biological role.

In my discussion of gender and race, I developed a short history of the concepts of race and racism that culminated in the poststructuralist vision of multiple black identities and the notion of choice. I already hinted at the incongruity of theory and practice. Racism, social and cultural prejudices and the economic injustice of class difference exclude most women of colour from any progress and possibilities of choice. Poetry on mothering corroborates this reservation. It shows how race and racism painfully affect the intimate mother-child relationship. The poem "Testament" by the Caribbean dub poet Jean 'Binta' Breeze demonstrates how the differences of race, class and economics destroy the selfconfidence of the mother and the confidence between parent and child. A black mother must teach her child how to survive in a racist society but not at the expense of self-esteem. In case of extreme poverty and illness, in the daily struggle of survival, even the emotional ties between a mother and her child change. In her poems "Bed-time Story" and "Pass Fe White", the Caribbean poet Louise Bennett uses parodies of racism as liberating act. Her apparently funny poems are extremely angry. The notions of what it means to be a mother are different from western values. Imtiaz Dharker's poem "Zarina's Mother" about a mother and her daughter in an Indian slum challenges our assumptions of mothering. Socially 
aware poetry indicts the devastating impact of class oppression on mothering. These poems supplement feminist theory that seems to have lost its interest in the investigation of class differences.

Antiracist mothering is regarded as the basic requirement for social change. Mothering experiences the connection of the personal with the political, the private with the cultural. Children are placed at the centre of social progress. Women's poetry on mothering deals with children's education and initiation into their societies. Examples are Kamala Das' poem "Initiation", Una Marson's "Cinema Eyes", Olive Senior's "Birdshooting Season." The future of our modern multi-cultural societies depends on this "maternal thinking" and "maternal practice". These poems advocate reforms of education in order to overcome stereotypes of gender roles and political actions to improve the economic and social situation of mothers and children. This poetry on mothering regards and respects the difference among individuals and societies and objects to generalisations. It agrees to the concept of differences of feminist theory and fills the "borderland around the edge" with life. The occupation and pre-occupation with difference is necessary to overcome the indifference towards inter-human relationships in most modern societies.

The theoretical part on difference concerning ethnicity dealt with the concepts of hybridity and nomadism for the process of integration and the relation between minority groups and their host societies. In this situation, mothers, who have always been regarded as reproducers and transmitters of ethic and ethnic values, experience a great responsibility. The poems analysed here indicate different directions. With the use of "here", I distance myself from any Eurocentric standardisation and homogenising tendencies. Confronted with the extremely complex and polyglot Indian, Caribbean and African cultures, I often experienced my procedure as personal and impressionistic. This changed my direction of research. I decided to give an overview and to draw attention to the need of further studies, for example, on the situation of the writer in the diaspora, the different topics and perspectives of women who do not belong to the "upper" and "middle" classes of their home countries, the English translation of their poetry. This short enumeration already points at the complexity of the field. With these reservations in mind, I carefully summarise my observations. Women from African and Caribbean contexts celebrate the matrilineal heritage as a source of self-esteem and empowerment. Their poems praise the particularities of traditions and speak against mixing and mimicry. Women poets from India deal with tradition in an opposite way. They denounce the main problem of our presence: the paralysing impact of history, tradition and religion and its fatal consequence of violence. Coming from a Catholic society in India, Eunice de Souza directs her irony and sarcasm against the hypocrisy and deceit of the Catholic Church. Imtiaz Dharker criticises the arrogance and intolerance of the Muslim culture and its disastrous effects on those living in the diaspora where rigid religious practice seems to be a shelter against 
the racism of the host country. Their poems on these conflicts exhort to mutual tolerance and respect - the basic requirements for a global feminism which connects Third World and Western feminism. Mahnaz Afkhami from Iran writes about her vision in her essay "Toward Global Feminism: A Muslim Perspective":

Waging their struggle in the colonial environment, Third World feminist thinkers have achieved a multicultural and intellectual formation and a plethora of experience relevant to the development of an internationally valid and effective discourse addressing women's condition on a global scale. The question is whether this foundation can become a springboard for a global discourse. By definition, such a discourse must transcend the boundaries of Christian, Jewish, Muslim, Buddhist, socialist, capitalist, or any other particular culture. It will be feminist rather than patriarchal, humane rather than ideological, balanced rather than extremist, critical as well exhortatory.[...] Non-western feminists can be instrumental in the development of a global feminism despite their historical handicap. [...] as the symmetry of the enclaves of poverty and backwardness in the developed and the developing countries is increasingly apparent, it becomes easier for Third World feminists to develop a sense of empathy with their sisters on other parts of the globe. Indeed, unless such empathy is effected and expanded, patriarchal norms, for all practical purposes, will not be transcended and feminism, global or otherwise, will not fully succeed. (Bell and Klein1996, 525-527)

Women's poetry on mothering meets these requirements and could become a part of this vision of a global discourse imagined by Mahnaz Afkhami. Women's poetry is not written from experience only, but also from empathy. Empathy is necessary to put oneself into another person's position, to see the world with another person's eyes. Poetry calls forth, however, not only empathy. It directs our attention to the use of language and the production of meaning. Poetry overcomes the limitations of realistic and autobiographical writing because it modifies and plays with language.

What I have shown is third, that the analysis of poems must be focussed on the poetic function of language. The focus on language pinpoints how meaning, values and political demands are produced and changeable. In my analysis of Lorna Goodison's poem "For My Mother / May I Inherit Half Her Strength", I distanced myself from any criticism that looks for a political programme or an ideology. In contrast to other interpretations, I show that the speaker of this dramatic monologue praises her mother, but also expresses her love for her father and celebrates the mutual love of her parents: a love that overcame all conflicts. Particularly feminist critical responses can be turned in the specific direction of detecting the major theme of "oppression" everywhere. Any search for unification, for a harmony of feeling, for a "maturity of acceptance" seems to impair feminist politics. In certain situations, women must develop a "strategic essentialism”. As an example, I included Lorna Goodison's poem “The Woman Speaks to the Man // Who Has Employed Her Son." Her enemy is the man who has made her son a child-soldier. But the term "strategic essentialism" has a propagandistic 
and martial connotation and can only be an answer to a special situation of conflict. From my practical work, I know that we run into trouble very quickly when we export "hard" traditional western feminism to the Third World. In this way, I have to re-consider the statement of my preface. Although I have already been careful to formulate the claim "Women deserve umbrellas like men" instead of "Women must have umbrellas like men", the generalisation must be changed to "This woman and probably more women in this part of Indian society deserve umbrellas". This statement points at the fact that these women still have to develop self-esteem in order to make claims for their needs. Global feminism must develop out of "locational feminism". Ama Ata Aidoo mentioned the generational gap experienced by feminism and the pressure forced upon women by all sorts of fundamentalisms. Economic independence is the basic requirement for women's respect in their families and their societies. Developmental projects are more and more working with this concept. This sort of "locational feminism" will realise social change in the long way. In one of these projects in India, one woman told me: "Finally we are standing on our own feet. We can care for our children and ourselves. We also help our men to overcome their depressions, their problems with alcohol and drugs. But if they don't change, we can leave them." This is rather a "womanist" than a "feminist" stance. The future of global feminism seems to depend on a change of its politics towards "womanism". Several poems on mothering analysed in my study convey a similar message. My study wants to direct further studies on feminist issues to both sites: those of conflicts and those of cohesion. At present day, the cuts, the divisions seem to predominate.

Mahnaz Afkhami fom Iran wrote about her "vision" of a global feminism. Audre Lorde claimed in the second preface of this study that our children need bread and poetry. She speaks about "dreams of new ideas":

Sometimes we drug ourselves with dreams of new ideas. The head will save us. The brain alone will set us free. But there are no new ideas waiting in the wings to save us as women, as human. There are only old and forgotten ones, new combinations, extrapolations and recognitions from within ourselves - along with the renewed courage to try them out. $(1984,38)$

Mahnaz Afkhami and Audre Lorde, both defy the gloom of defeat. Women's poetry on mothering takes the same position. These poems call for resistance and add "the principle of hope". In spite of the difficulties of modern societies, these writers reaffirm the faith in the power of the written word, to reach out, to instruct, to empower and to encourage. The rays of hope are, however, often extremely small and one must force oneself to hope against despair as it is expressed in the last poem on mothering that concludes this study. In her poem "For Hope," the Caribbean dub poet Jean 'Binta' Breeze speaks about patience and memories. She finds consolation in faith. Those who cannot find refuge in Christian belief can, however, omit the last two lines and listen to a mother's comforting voice. 
For $\mathrm{Hope}^{67}$

chile,

don't yuh ever forget de vision dat

keep alight shining in de eye dat

keep yuh fresh as a petal flowing troo

a gutter a filt dat

wen de music playing troo yuh heart in

a dozen concerto a pain bringing

memories of warm rain and

want

brushing out shapes a dawn like silky scarves

after the twilight mischief

wen yuh get caught up in de fight don't

don't ever forget de vision

sit still awhile an let thoughts roam de

deepness of yuh wound

an clean de uncaring

let dem wash like new spring waters cooling

troo de system

till it touch de mind wid awakening an

cast off de shadows of doubt

chile,

don't yuh ever forget de vision dat

keep a light shining in de I

we in de hands, chile

we in de Hand

${ }^{67}$ Breeze, Jean ,Binta’. „For Hope“. Spring Cleaning. London: Virago Press, 1992. 70. 


\section{Selected Bibliography}

\section{Primary}

Aidoo, Ama Ata (1995). “Gynae I", “For Kinna II." The Heinemann Book of African Women's Poetry. Eds. Stella and Frank Chipasula. London: Heinemann, 43-45, 47-50.

Apollinaire, Guillaume (1965). "Il Pleut". Ouevres poetiques. Paris: Bibl.de la Pléiade, 203.

Awoonor, Kofi (1976). "To Sika". A Selection of African Poetry. Eds. Kojo Senanu and Theo Vincent. Burnt Mill, Harlow, Essex: Longman, 155-156.

Bennett, Louise (1966). "Pass Fe White". Jamaica Labbrish. Jamaica, W. J.: Sangster's Bookstores Jamaica, 212-213.

--- (1996). "Bed-time Story", " Proverbs". The Routledge Reader in Caribbean Literature. Eds. Alison Donnell and Sarah Lawson Welsh. London and New York: Routledge, 146-148.

Bernikow, Louise, ed (1979). The World Split Open. Women Poets 1552-1950. London: The Women's Press.

Bhatt, Sujata (1988). "Kalika”. Brunizem. Manchester: Carcanet Press Limited, 24

Bradstreet, Anne (1979). "Before the Birth of One of Her Children". The World Split Open. Women Poets 1552-1950. Ed. Louise Bernikow. London: The Women's Press, 192-193.

Bradstreet, Anne (1994). "To My Dear Children". The Harper American Literature.

Second Edition, Volume 1. Eds. Donald McQuade, et al. New York: Harper

Collins College Publishers, 187-190.

Breeze, Jean 'Binta' (1992). "Testament”, “Atlantic Drift”, "For Big Mammy”, "Birthing", "Moonwise", "For Hope", "Mother... Sister... Daughter...". Spring Cleaning. London: Virago Press, 7-11, 37, 46-47, 55-56, 70, 74. 
Burnett, Paula, ed (1986). The Penguin Book of Caribbean Verse in English. London: Penguin Books.

Chipasula, Stella (1995). "Your Name is Gift". The Heinemann Book of African Women's Poetry. Eds. Stella and Frank Chipasula. London: Heinemann, 132.

Chipasula, Stella and Frank, Eds (1995). The Heinemann Book of African Women's Poetry. London: Heinemann.

Chitre, Dilip (1992). "Father Returning Home". The Oxford India Anthology of Twelve Modern Indian Poets. Ed. Arvind Krishna Mehrotra. Calcutta: Oxford University Press, 112.

Collier, Gordon, ed (2002). Up from Under: Poetry by Women from the Caribbean and the Diaspora. Reader for the $6^{\text {th }}$ Autumn Summer School on the New Literatures in English. Berlin: Humboldt-University.

Cope, Jack and Uys Krige, eds (1968). The Penguin Book of South African Verse. Harmondsworth, Middlesex: Penguin Books Ltd.

Couzyn, Jeni (1995). "Spell for Birth", "The Mystery", "Heartsong”. The Heinemann Book of African Women's Poetry. Eds. Stella and Frank Chipasula. London: Heinemann, 172, 173.

d'Almeida, Irène Assiba (1995). "Sister, You Cannot Think a Baby out!" The Heinemann Book of African Women's Poetry. Eds. Stella and Frank Chipasula. London: Heinemann, 41-42.

Das, Kamala (1973). “An Introduction”, "My Grandmother's House”, 'Nani”. The Old Playhouse and Other Poems. Bombay: Orient Longman, 26-27, 32, 40.

De Cervantes Saavedra, Miguel (1963). ElIngenioso Hidalgo Don Quijote de la Mancha. Ed. J. Perez del Hoyo. Madrid: Lit. Barrero, S. L., 549.

De Kok, Ingrid (1995). "Small Passings", “Al Wat Kind Is”. The Heinemann Book of African Women's Poetry. Eds. Stella and Frank Chipasula. London: Heinemann, 181, 183.

De Souza, Eunice, ed (2001). "Catholic Mother", "For a Child, Not Clever". Nine Indian Women Poets - An Anthology. Oxford: Oxford University Press, 39-40.

--- (1992). “Sweet Seventeen”, “For Rita’s Daughter, Just Born”. The Oxford India Anthology of Twelve Modern Indian Poets. Ed. Arvind Krishna Mehrotra. Oxford: Oxford University Press, 116, 121.

Dharker, Imtiaz (1989). "Purdah I", "Purdah II", "Zarina's Mother", “Choice”, "Outline". Purdah and other poems. Oxford: Oxford University Press, 14, 16, 42, 49, 53.

--- (1997). “Living Space”, “Adam’s Daughter". Postcards from god. Newcastle upon Tyne: Bloodaxe Ltd, 109, 130.

Dharwadker, Vinay and A. K. Ramanujan, eds (1994). The Oxford Anthology of Modern Indian Poetry. New Delhi: Oxford University Press. 
Goodison, Lorna (1986). "Songs for My Son”, "I am Becoming My Mother", "For My Mother". I Am Becoming My Mother. London/Port of Spain: New Beacon Books, 17-18, 38, 46-48.

--- (1995). For Us, All Flowers Are Roses. Urbana and Chicago: University of Illinois Press.

--- (1995). “The Woman Speaks to the Man Who Has Employed Her Son”. For Us, All Flowers Are Roses. Urbana and Chicago: University of Illinois Press, 5152.

Harper, Frances E. W (1979). "The Slave Mother". The World Split Open. Women Poets 1552-1950. Ed. Louise Bernikow. London: The Women’s Press. 214 215.

Hughes, Langston (1998). "The Weary Blues". The Norton Anthology of American Literature. Fifth Edition / Volume 2. Eds. Nina Baym et al. New York/London: W.W. Norton \& Company, 1732-1733.

King, Jane(1996). “Intercity Dub (for Jean 'Binta' Breeze)". The Routledge Reader in Caribbean Literature. Eds. Alison Donnell and Sarah Lawson Welsh. London and New York: Routledge, 385-387.

Jonker, Ingrid (1995). "The Child who was Shot Dead by Soldiers at Nyanga". The Heinemann Book of African Women's Poetry. Eds. Stella and Frank Chipasula. London: Heinemann, 151.

Maja-Pearce, Adewale, ed (1990). The Heinemann Book of African Poetry in English. London: Heinemann.

Markham, E. A., ed (1989). Hinterland - Caribbean Poetry from the West Indies and Britain. Newcastle upon Tyne: Bloodaxe Books Ltd.

Marson, Una (1996). "Cinema Eyes". The Routledge Reader in Caribbean Literature. Eds. Alison Donnell and Sarah Lason Welsh. London and New York: Routledge, 138-140.

--- (2002). "Brown Baby Blues". Up From Under: Poetry by Women from the West Indies and the Diaspora. Ed. Gordon Collier. Berlin: Humboldt-University, 43.

Mcquade, Donald, et al, eds (1994). The Harper American Literature. Second Edition, Volume 1. New York: Harper Collins College Publishers.

Mehrotra, Arvind Krishna, ed (1992). The Oxford India Anthology Of Twelve Modern Indian Poets. Oxford: Oxford University Press.

Mordecai, Pamela and Mervyn Morris, eds (1980). Jamaica Woman - An Anthology of Poems. London, Kingston, Port of Spain: Heinemann.

Mugo, Micere Githae (1995). "Where are those songs?” The Heinemann Book of African Women's Poetry. Eds. Stella and Frank Chipasula. London: Heinemann, 129-131. 
Mwana Kupona binti Msham (1995). "Poem to her Daughter". The Heinemann Book of African Women's Poetry. Eds. Stella and Frank Chipasula. London: Heinemann, 126.

Naidu, Sarojini (2003). "The Palanquin - Bearers". An Illustrated History of Indian Literature in English. Ed. Arvind Krishna Mehrotra. Delhi: Permanent Black, 132.

Nichols, Grace (1990). "Epilogue". $i$ is a long memoried woman. Grace Nichols. London: Karnak House, 85.

Pearn, Julie, ed (1985). Poetry in the Caribbean. London: Hodder and Stoughon.

Peters, Lenrie (1976). "She came in silken drapes". A Selection of African Poetry. Eds. Kojo Senanu and Theo Vincent. Bunt Mill, Harlow, Essex: Longman, 110 111.

Plath, Sylvia (1997). "Metaphors". An Introduction to Literature. Eleventh Edition. Ed. Sylvan Barnet et al. New York: Longman, 555.

--- (1998). "Purdah". The Norton Anthology of American Literature. Fifth Edition / Volume 2. Ed. Nina Baym. New York/London: W. W. Norton and Company, 2751-2753.

Rungano, Christina (1995). "Labour". The Heinemann Book of African Women's Poetry. Eds. Stella and Frank Chipasula. London: Heinemann, 209.

Salkey, Andrew, ed (1971). Breaklight - an anthology of Caribbean poetry. London: Hanish Hamilton.

Senanu, K. E. and T. Vincent, eds (1976). A Selection of African Poetry. Burnt Mill, Harlow, Essex: Longman.

Senior, Olive (1998). "Birdshooting Season", "Epitaph", "Childhood”, "One Night, the Father", "rain". Hinterland-Caribbean Poetry from the West Indies and Britain. Ed. E. A. Markham. New Castle upon Tyne: Bloodaxe Books Ltd, 217-226.

--- (2002). "The Mother". Up from Under: Poetry by Women from the Caribbean and the Diaspora. Ed. Gordon Collier. Berlin: Humboldt-University, 71.

Silgardo, Melanie (2001). "Child”, "Do not Tell the Children”. Nine Indian Women Poets - An Anthology. Ed. Eunice de Souza. Oxford: Oxford University Press, $30,33$.

Sulter, Maud (1985). As A Black Woman. London: Akira Press.

\section{Secondary}

Afkhami, Mahnaz (1996). "Towards Global Feminism: A Muslim Perspective." Radically Speaking - Feminism Reclaimed. Eds. Diane Bell and Renate Klein. London: Zed Books, 552-557. 
Anzaldúa, Gloria (1987). Borderlands / La Frontera: The New Mestiza. San Francisco: Spinster/Aunt Lute Books.

Azim, Firdous and Niaz Zaman (1994). Infinite V ariety - Women in Society and Literature. Dhaka/Bangladesh: University Press Limited.

Barnet, Sylvan, ed (1997). An Introduction to Literature. 11 th edition. New York: Longman, 612.

Bell, Diane and Renate Klein, eds (1996). Radically Speaking - Feminism Reclaimed. London: Zed Books.

Bell, Roseann P., Bettye J. Parker and Beverly Guy-Sheftall, eds (1979). Sturdy Black Bridges: Visions of Black Women in Literature. New York: Anchor Press/Doubleday.

Bellamy, Susanne (1996). "The Narrow Bridge of Art and Politics." Radically Speaking - Feminism Reclaimed. Eds. Diane Bell and Renate Klein. London: Zed Books, 126-134.

Benson, Eugene and L. W. Conolly, eds (1994). Encyclopedia of Post-Colonial Literatures in English. London and New York: Routledge.

Bhabha, Homi K. (1994). The Location of Culture. London and New York: Routledge.

Bock, Gisela and Susan James, eds (1992). Beyond Equality and Difference - citizenship, feminist politics, female subjectivity. London: Routledge.

Breeze, Jean 'Binta' (1996). “Can a Dub Poet be a Woman?” Women: a Cultural Review, 1, 1: 47-49, reprinted in The Routledge Reader in Caribbean Literature. Eds. Alison Donnell and Sarah Lawson Welsh. London and New York: Routledge, 498-500.

Brooks, Ann (1997). Postfeminisms - Feminism, Cultural theory and cultural forms. London and New York: Routledge.

Brown, Lloyd W. (1981). Women Writers in Black Africa. London, Westport: Greenwood Press.

Burnett, Paula (2002-2003). "Derek Walcott on Poetry, Pity and Power: An Interview” (1988). Reprinted in Agenda, Bd. 39, 1-3: 139-153.

Butler, Judith (1990). Gender Trouble. New York and London: Routledge.

--- (1992). "Contingent foundations: feminism and the question of 'postmodernism". Feminists Theorise the Political. Eds. Judith Butler and J. W. Scott. London: Routledge, 3-22.

Cartey, Wilfred (1971). Whispers from a Continent: The Literature of Contemporary Black Africa. London: Heinemann.

Childs, Peter and Patrick Williams (1997). An Introduction to Post-Colonial Theory. London: Longman.

Chodorow, Nancy (1978). The Reproduction of Mothering: Psychoanalysis and the Sociology of Gender. Berkeley: University of California Press. 
Christian, Barbara (1987). "The Race for Theory”, Cultural Critique, 6: 51-63.

--- (1997). "The Highs and Lows of Black Feminist Criticism.” (1990) Feminisms an anthology of literary theory and criticism. Eds. Roby R. Warhol and Diane Price Herndl. New Brunswick, New Jersey: Rutgers University Press, 51-56.

Collier, Gordon (2002). "The West Indies." Companion to the New Literatures in English. Ed. Christa Jansohn. Berlin: Erich Schmidt Verlag, 110-136.

Daly, Mary (1979). Gyn / Ecology. London: The Women's Press.

Das, Sanjuhta (1978). "Mothering Poetry: Balami Amma and Kamala Das. Journal of the Department of English / University of Calcutta, 195-212.

Davies, Carole Boyce and Anne Adams Graves, eds (1986). Ngambika-Studies of Women in African Literature. Trenton, New Jersey: Africa World Press, Inc.

Davies, Carole Boyce and Elaine Savory Fido, eds (1990). Out of the Kumbla - Caribbean Women and Literature. Trenton, New Jersey: African World Press.

deCaires Narain, Denise (2004). "Lorna Goodison with Denise deCaires Narain”(1989). Writing Across Worlds - Contemporary writers talk. Ed. Susheila Nasta. London and New York: Routledge, 45-57.

Derrida, Jaques (1991). “Che cos’ ̀̀ la poesia?” A Derrida Reader. Between the Blinds. Ed. Peggy Kamuf. New York: Columbia University Press, 221-237.

De Souza, Eunice (2004). Purdah - An Anthology. New Delhi: Oxford University Press.

De Souza, Eunice and Lindsay Pereira, eds (2002). Women's Voices - Selections from Nineteenth and Early-Twentieth Century Indian Writing in English. New Delhi: Oxford University Press.

Donnell, Alison (1996). "Contradictory (W)omens?: Gender Consciousness in the Poetry of Una Marson.” (1995) The Routledge Reader in Caribbean Literature. Eds. Alison Donnell and Sarah Welsh. London and New York: Routledge, 187193.

Donnell, Alison and Sarah Welsh, eds (1996). The Routledge Reader in Caribbean Literature. London and New York: Routledge.

Edmondson, Belinda (1999). Making Men - Gender, Literary Authority, and Women's Writing in Caribbean Narrative. Durham and London: Duke University Press.

Fanon, Frantz (1967). Black Skin, White Masks. Trans. C. L. Markmann. New York: Grove Press, 161.

--- (1967). The Wretched of the Earth. Trans. Constance Farrington. Harmondsworth: Penguin.

Fellows, Mary Louise and Sherene Razack (1994). "Seeking Relations: Law and Feminism Roundtables.” Signs 19, Summer: 1048-1083.

Felski, Rita (1989). Beyond Feminist Aesthetics - Feminist Literature and Social Change. London: Hutchinson Radius. 
Ferguson, Ann (1983). "On Conceiving Motherhood and Sexuality: A Feminist Materialist Approach." (1982) Mothering - Essays in Feminist Theory. Ed. Joyce Trebilcot. Savage, Maryland: Rowman and Littlefield Publishers, Inc., 153184.

Fido, Elaine Savory (1990). "Textures of Third World Reality in the Poetry of Four African-Caribbean Women." Out of the Kumbla - Caribbean Women and Literature. Eds. Carole Boyce Davies and Elaine Savory Fido. Trenton, NY: African World Press, 29-44.

Foucault, Michel (1977). The Archaeology of Knowledge. London: Tavistock.

Friedman, Susan Stanford. (1987). "Creativity and the Childbirth Metaphor: Gender Difference in Literary Discourse." Feminist Studies 13: 49-82.

--- (1998) Mappings. Feminism and the Cultural Geographies of Encounter. Princeton, New Jersey: Princeton University Press.

Gobineau, J. A. (1997). "Essay on the Inequality of Human Races." (1853). An Introduction to Post-Colonial Theory. Eds. Peter Childs and Patrick Williams. Harlow, England: Longman, 189.

Hawthorn, Jeremy (2000). A Glossary of Contemporary Literary Theory. London: Arnold.

Hirsch, Edward (1999). How to Read a Poem - And Fall in Love with Poetry. San

Diego, New York, London: A Harvest Book, Harcourt, Inc.

Hobsbaum, Philip (2001). Metre, Rhythm and Verse Form. London and New York: Routledge.

Hooks, Bell (1981). Ain't I a Woman - black women and feminism. Boston MA: South End Press.

--- (1991). "Postmodern Blackness." Yearning: Race, Gender and Cultural Politics. London: Turnaround, 28.

Hossein, Roquiah Sakhawat (2002). „Sultana’s Dream.“ God Gives, Man Robs and Other Writings. Roquiah Sakhawat Hossein. Bangladesh: Narigrantha Prabartana. The Feminist Bookshop, 29-48.

Hurston, Zora Neale (1986). Their Eyes were watching God. (1937). London: Virago Press.

Jackson, Stevi and Sue Scott, eds (1996). Feminism and Sexuality: A Reader. Edinburgh: Edinburgh University Press.

James, Adeola, ed (1990). In Their Own Voices - African Women Writers Talk. London: Heinemann.

Jansohn, Christa, ed (2002). Companion to the New Literatures in English. Berlin: Erich Schmidt Verlag.

Kamuf, Peggy, ed (1991). A Derrida Reader. Between the Blinds. New York: Columbia University Press. 
King, Bruce, ed (1996). New National and Post-Colonial Literatures - An Introduction. Oxford: Clarendon Press.

--- (2004). Modern Indian Poetry in English. (Revised Edition). Oxford/India Paperbacks: Oxford University Press.

Kristeva, Julia (1986). "Revolution in Poetic Language.” (1974) The Kristeva Reader. Ed. Toril Moi. Oxford: Blackwell.

Landry, Donna and Gerald MacLean (1996). The Spivak Reader. Selected Works of Gayatri Chakravorty Spivak. London and New York: Routledge.

Lauter, Paul, ed (1998). The Heath Anthology of American Literature. Third Edition. Volume 2. Boston/New York: Houghton Mifflin Company.

Loomba, Ania, ed (1998). Colonialism / Post Colonialism. London: Routledge.

Lorde, Audre (1984). Sister Outsider. Essays and Speeches. Freedom, CA: The Crossing Press.

Lazarus, Neil, ed (2004). The Cambridge Companion to Postcolonial Literary Studies. Cambridge: Cambridge University Press.

McDowell, Deborah E. (1985). "New Directions for Black Feminist Criticism." (1980). The New Feminist Criticism. Essays on Women, Literature and Theory. Ed. Elaine Showalter. New York: Pantheon Books, 186-199.

--- (1997). "Recycling: Race, Gender, and the Practice of Theory." (1997). Feminisms - an anthology of literary theory and criticism. Eds. Robyn R. Warhol and Diane Price Herndl. New Brunswick, New Jersey: Rutgers University Press, 234-247.

McQuade, Donald, ed (1994). The Harper American Literature. Second Edition. Volume I. New York: Harper Collins College Publishers.

Mehrotra, Arvind Krishna, ed (2003). An Illustrated History of Indian Literature in English. Delhi: Permanent Black.

Miller, Nancy K., ed (1986). The Poetics of Gender. New York: Columbia University Press.

Mirza, Heidi Safia, ed (1992). Young, Female and Black. London: Routledge.

---, ed (1997). Black British Feminism: A Reader. London and New York: Routledge.

Mohanty, Chandra Talpade (1994). "Under Western Eyes: Feminist Scholarship and Colonial Discourses." Colonial Discourse and Post-Colonial Theory-A Reader. Eds. Patrick Williams and Laura Chrisman New York: Columbia University Press, 214-216.

--- (2003). Feminism without Borders - Decolonizing Theory, Practicing Solidarity. Durham \& London: Duke University Press.

Moi, Toril, ed (1986). The Kristeva Reader. Oxford: Blackwell.

Montefiore, Janet (1990). "Thinking about Mothers." Women: a cultural review. London: Taylor and Francis, 303-309. 
--- (2004). Feminism and Poetry. Language, Experience, Identity in Women's Writing. London: Pandora.

Moore, Henrietta L. (1994). A Passion for Difference: Essays in Anthropology and Gender. Bloomington: Indiana UP.

Morris, Mervyn (1996). "On Reading Louise Bennett, Seriously.” (1967) The Routledge Reader in Caribbean Literature. Eds. Alison Donnell and Sarah Welsh. London and New York: Routledge, 194-197.

Mulvey, Laura (1997). "Visual Pleasure and Narrative Cinema." Feminisms - an anthology of literary theory and criticism. New Brunswick, New Jersey: Rutgers University Press, 438-448.

Naidu, Sarojini (2003). "Speeches and Writings of Sarojini Naidu." (1918) An Illustrated History of Indian Literature in English. Ed. Arvind Krishna Mehrotra. Delhi: Permanent Black, 134.

Nasta, Susheila, ed (1991). Motherlands. Black Women's Writing from Africa, the Caribbean and South Asia. New Brunswick, New Jersey: Rutgers University Press.

--- (1996). Dynastic Span - Susheila Nasta on the Heinemann Book of African Women's Poetry. London: Poetry Review, Band 86, 1: 72.

--- (2000). “Beyond the Millenium: Black Women's Writing.” Women : a Cultural review. 11, 1: 71-76.

--- (2004). Writing Across Worlds - Contemporary writers talk. London and New York: Routledge.

Ngcobo, Lauretta, ed (1987). Let It Be Told - Essays by Black. Women in Britain. London: Virago Press.

Ostriker, Alicia Suskin (1986). Stealing the Language - The Emergence of Women's Poetry in America. Boston: Beacon Press.

Papke, Renate (2004). "Mothers and Poets: Mothering and Children in Modern American Women's Poetry.” M.A.-Thesis. TU Braunschweig/Germany.

Raghunandan, Lakshmi (1990). Contemporary Indian Poetry in English. New Delhi: Reliance Publishing House.

Reyes, Angelita (2002). Mothering Across Cultures. Postcolonial Representations. Minneapolis (and London): University of Minnesota Press.

Rich, Adrienne (1976). OfWoman Born: Motherhood as Experience and Institution. New York: W. W. Norton and Company Inc.

Ruddick, Sara (1989). Maternal Thinking. Toward a Politics of Peace. The first attempt to describe from a philosophical perspective, the thinking that grows out of the work mothers do. New York: Ballantine Books.

Rushdie, Salman (1992). Imaginary Homelands. London: Granta Books.

Rutherford, Anna (1986). "Interview with Olive Senior," Kunapipi 8, no 2: 11-20. 
--- (1989). Hinterland - Caribbean Poetry from the West Indies and Britain. Ed. E. A. Markham. Newcastle upon Tyne: Bloodaxe Books Ltd, 212-216.

Said, Edward W. (1978). Orientalism. London: Routledge and Kegan Paul.

Sarobji, Cornelia (2003). "Love and Life Behind the Purdah." (1918) An Illustrated History of Indian Literature in English. Ed. Arvind Krishna Mehrotra. Delhi: Permanent Black, 134.

Scott, Dennis (1989). "Bennett on Bennett - Louise Bennett interviewed by Dennis Scott." (1968) reprinted in E. A. Markham, ed. Hinterland-Caribbean Poetry from the West Indies and Britain. New Castle upon Tyne: Bloodaxe Books, 4550.

Sellers, Susan, ed (1994). Hélène Cixous Reader. London: Routledge.

Senior, Olive (1991). Working Miracles - Women's Lives in the English-speaking Caribbean. Bloomington and Indianapolis: Indiana University Press.

Sharpe, Jenny (2003). 'Dub and Difference - A Conversation with Jean 'Binta' Breeze." Callaloo: a black south journal of arts and letters. Lexington, Ky. 26.3, 607613.

Showalter, Elaine, ed (1985). The New Feminist Criticism. Essays on Women, Literature and Theory. New York: Pantheon Books.

Smith, Barbara (1985). "Toward a Black Feminist Criticism.” (1977). The New Feminist Criticism. Essays on Women, Literature and Theory. Ed. Elaine Showalter. New York: Pantheon Books, 168-185.

Spivak, Gayatri Chakravorty (1987). In Other Worlds: Essays in Cultural Politics. New York: Methuen.

--- (1992).'French Feminism Revisited: Ethics and Politics." Feminists Theorize the Political. Eds. Judith Butler and Joan W. Scott. London, New York: Routedge, 54-85.

--- (1993). Outside the Teaching Machine. London: Routledge, 13.

--- (1994). "Can the Subaltern Speak?" Colonial Discourse and Post-Colonial Theory: $A$ Reader. Eds. Patrick Williams and Laura Chrisman. New York: Harvester Wheatsheaf, 66-111.

--- (1996). "Echo." The Spivak Reader. Eds. Donna Landry and Gerald MacLean. New York: Routledge, 175-202.

--- (1996). “How to Teach a 'Culturally Different' Book?” The Spivak Reader. Eds. Donna Landry and Gerald MacLean. New York: Routledge, 237-266.

--- (1996) "Translator's Preface and Afterword to Mahasweta Devi: Imaginary Maps." The Spivak Reader. Eds. Donna Landry and Gerald MacLean. New York: Routledge, 267-286.

Suleri, Sara (1989). Meatless Days. Chicago: University of Chicago Press.

--- (1992). "Woman Skin Deep: Feminism and the Postcolonial Condition." Critical Inquiry, 18: 756-769. 
Tharu, Susie and K. Lalita, eds (1991). Women Writing in India. 600 B. C. to the Present. Volume I: 600 B. C. to the Early Twentieth Century. London: Pandora Press.

--- (1993). Women Writing in India. 600 B. C. to the Present. Volume II: The Twentieth Century. New York: The Feminist Press at the City University of New York.

Trebilcot, Joyce, ed (1983). Mothering - Essays in Feminist Theory. Savage, Maryland: Rowman and Littlefield Publishers, Inc.

Walker, Alice (1984). In Search of Our Mothers' Gardens: Womanist Prose. London: The Women's Press.

Walmsley, Anne (1989). “A Far Reaching Voice.” Hinterland - Caribbean Poetry from the West Indies and Britain. Ed. E. A. Markham. Newcastle upon Tyne: Bloodaxe Books Ltd, 231-234.

Warhol, R. Robyn and Diane Price Herndl, eds (1997). Feminisms - an anthology of literary theory and criticism. New Brunswick, New Jersey: Rutgers University Press.

Webster (2001): Webster's Universal College Dictionary. New York: Random House.

Weedon, Chris (1987). Feminist Practice and Poststructuralist Theory. Oxford: Basil Blackwell.

--- (1999). Feminism, Theory and the Politics of Difference. Oxford: Blackwell Publishers.

Whitback, Caroline (1983). "The Maternal Instinct" (1972) and "Afterword to the Maternal Instinct” (1982). Mothering - Essays in Feminist Theory. Ed. Joyce Tre-

bilcot. Savage, Maryland: Rowman and Littlefield Publishers, Inc., 185-198.

Williams Patrick and Laura Chrisman, eds (1994). Colonial Discourse and Post-Colonial Theory. A Reader. New York: Columbia University Press.

Wilson, Nana Tagoe (2004). “Ama Ata Aidoo with Nana Wilson-Tagoe.” Contemporary writers talk. Ed. Susheila Nasta. London, New York, 292-300.

Wisker, Gina, ed (1993). Black Women's Writing. London: MacMillan.

--- (2000). Post-Colonial and African American Women's Writing - A Critical Introduction. London: MacMillan Press, LTD.

\section{Internet Sources}

(1) Kamal Das. "Let us invade the brothels and rescue the children!" available from Rediff On The Net, Life/Style. 29 December 2005. <http://www.rediff/com/style/1996/1011das.htm>

(2) "Eunice de Souza - Head of Department." 15 February 2006. $<$ http://arlindo-correia.com/1000501.html>

(3) Palmer, Henry. 'Jean 'Binta' Breeze.” new internationalist, issue 31 March 1999, cited 21 February 2006, <http://www.newint.org/issue310/interview.htm> 
T his study consists of two parts. The first part offers an overview of feminism's theory of differences. The second part deals with the textual analysis of poems about 'mothering' by women from India, the Caribbean and Africa. Literary criticism has dealt with the representation of 'mothering' in prose texts. The exploration of lyrical texts has not yet come.

Since the late 1970s, the acknowledgement of and the commitment to difference has been fundamental for feminist theory and activism. This investigation promotes a differentiated, 'locational' feminism (Friedman). The comprehensive theoretical discussion of feminism's different concepts of 'gender', 'race', 'ethnicity' and 'mothering' builds the foundation for the main part: the presentation and analysis of the poems. The issue of 'mothering' foregrounds the communicative aspect of women's experience and wants to bridge the gap between theory and practice. This study, however, does not intend to specify 'mothering' as a universal and unique feminine characteristic. It underlines a metaphorical use and discusses the concepts of 'nurturing', 'maternal practice' and 'social parenthood'. This metaphorical application supports a practice that could lead to solidarity among women and men in social and political fields. In spite of its ethical - political background, this study does not intend to read the selected poems didactically. The analyses of the poems always draw the attention to the aesthetic level of the texts. Regarding the extensive material, this study understands itself as an explorative not concluding investigation placed at the intersections of gender studies, postcolonial and classical literary studies. Most of all, it aims at initiating a dialogue and interchange between scholars and students in the Western and the 'Third World'. 